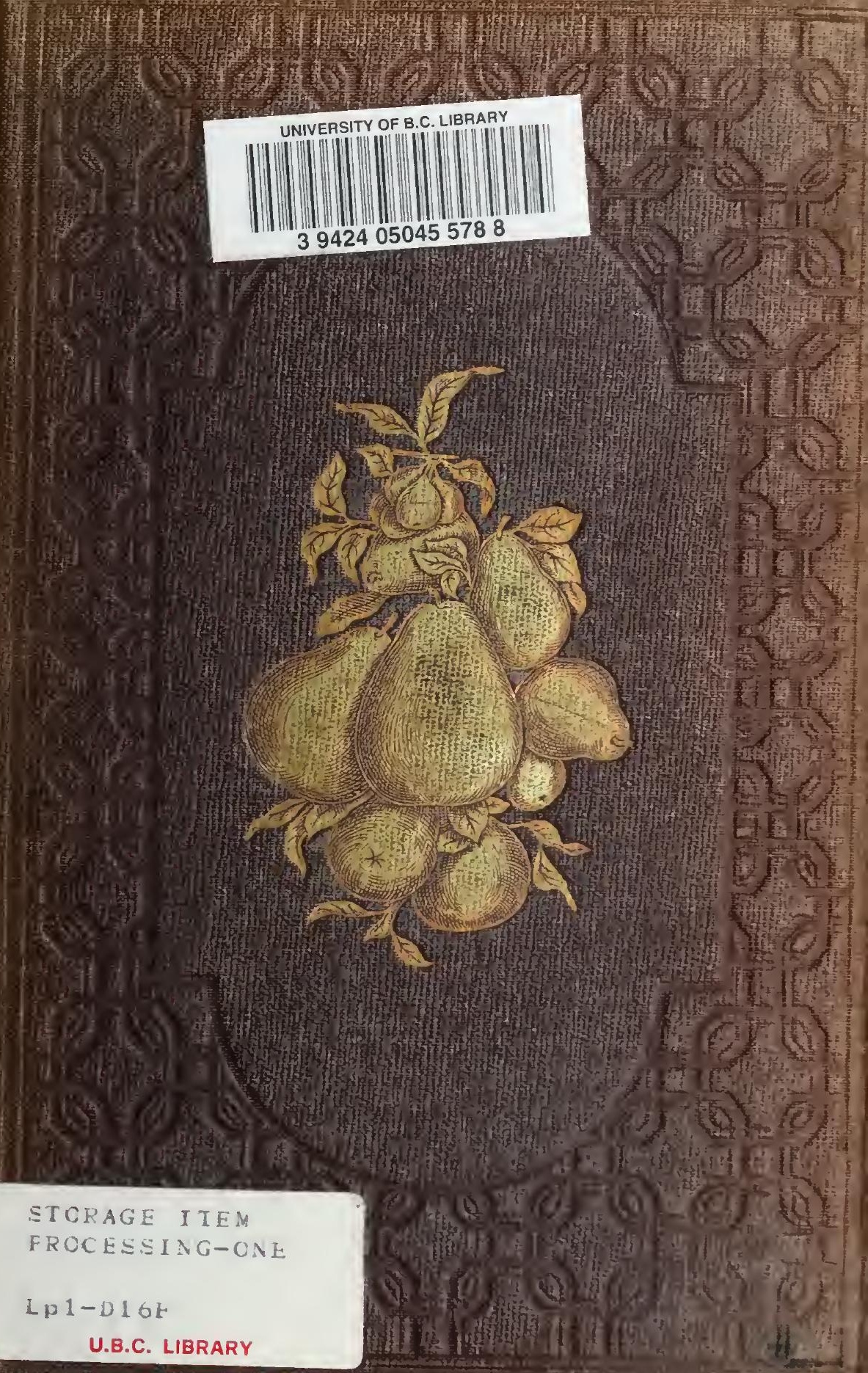




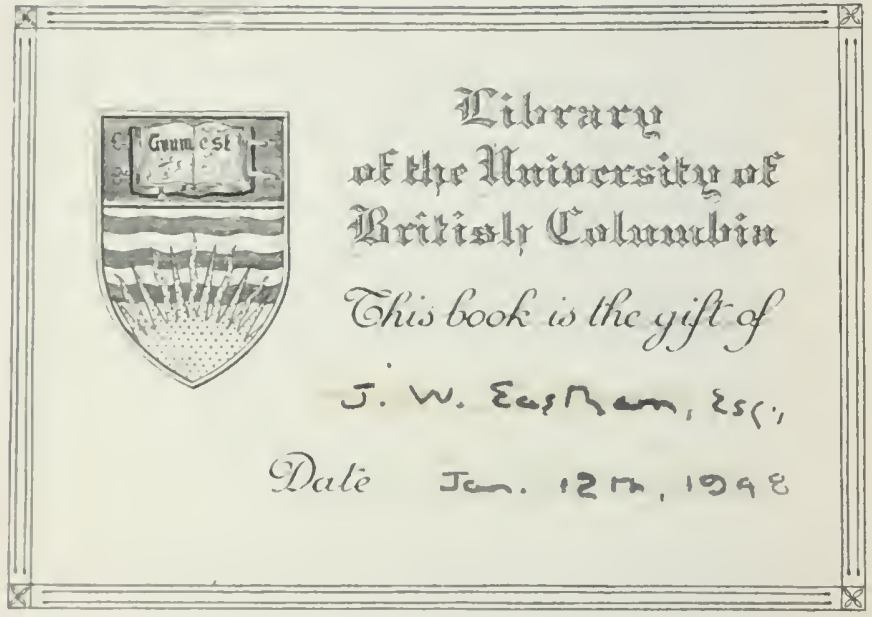





Digitized by the Internet Archive in 2010 with funding from University of British Columbia Library 


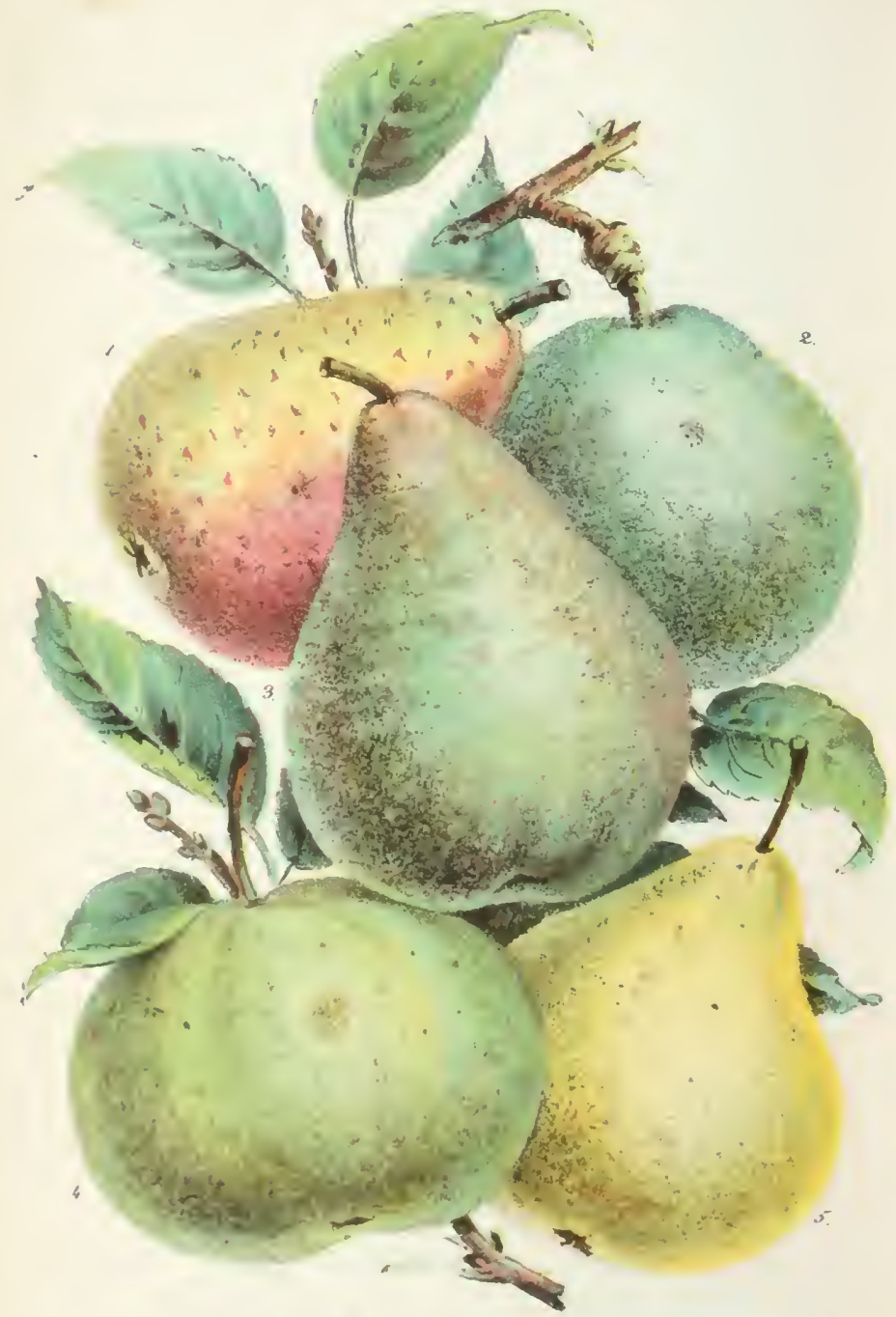

Hedured to bo the dinmeler of natuml sege
1. . Ibbot
3. Brusrer fieperlin .
¿ Belle Lurerreliser.
4. Menersiser firulle.

5 Howell. 


\title{
PEAR CUTTURE.
}

\section{A II A NUAL}

FOR TIE

\section{PROPAGATION, PLANTING, CULTIVATION, AND MINAGEMENT}

\author{
OF \\ THE PEAR TREE.
}

WTIT

DESCRIPTIONS AND ILLCSTRATIONS OF THE MOST PRODCCTIFE

OF THE FINEP VARIETIES, AND SELECTIONS OF KINDS MOST PROFITABLY GROWN FOR MAPKET.

BY

TIIOS. W. FIELD.

Frr golden-dropping Pear, the reddening glow Ciman the clitik of Busuty, mil the Peach, Hrive common source and end. The Inust

We till, we are. The nodding flower, tho Flun, Arebing in cluisters and in rathed aisles, are inan, or beswt, or worm, in other furms.
No marble dnmb, or crumbling tomb shail rear Their psle chill walls o'er me. The tree I Firn Shall monument my dust- Lo.lf the troe,

Refined in leaf, unil fruis and tluwer: tlust when The immiturial part pota mattas ust Agsin, it is mure fit fur llewver.

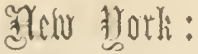

A. O MOORE, $\Lambda$ GRICLLTURAL BOOK PLBLISIIER, 140 FULTON STREET.

1859. 
kntered, according to $\Lambda$ ct of Congress, in the year 1848

B $\Lambda$. U. MOORE

In the Clerk's Oflice of the District Court fur tho Southerr District of New York. 


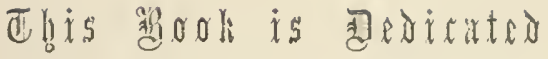 TO MY FRIEND,}

DR. IOUIS E. BEIOIIMAIS, $\triangle B \quad b$

MAEB OF AFTEOTION $\triangle N D$ BEBPEOT.

TIIE A UTIIOR. 



\section{P R E F $\perp$ C E.}

THe pleasure with which I have, for several years, pursued the lator of collecting and arrangmg the matter of this Book, melts away, as I approach the tribunal which is to pronounce upon the result of that labor. The Public which an auther fears most is, after all, very small-it is those of his own craft, who will easily discover his fitilure; and it is precisely that small Public whose faror $I$ an most anxions to descrve. Cardinal DE Retz once sitid: "II who is in good repute among his own oider, can not easily be overthrom."

It is from intelligent Pomologists that I shall receive censure with the most humility, and praise with the most gratification; and it was in hope of earning the latter that I have oegun and completed this work.

There is so little that is really original in any work, that the unguarded and jealous critic, in reviewing some humble anthor, is in imminent danger of launching his bolt a.t some great and standard anthority. When charged, by a critic of such rank, with imperfections, I shall only be able to ansirer: "Sir, the best Pomologists have contributed the most perfect results of their investigations to this work; and the insensible plagiarism, by which another's idea is reproduced in my brain, onght not to ereate prejudice against the idca." So much of what is excellent in this work may, by long residence in my own brain, seen to lave hat its origin there, that it would 
be vain to attempt, at this late hour, a restitution of icleas to the properowners. When known or recollected, the anthority whose matter has been quoted is noticed in the looly of the work.

It requires to be distinetly stated, that the plan of this look does not almit of that extensive description of varieties which would be desired by an antem of long experience in the enliration of the Pear. Its clesign is to answer, in a elear and intelligible manner, the oftrepeaterl puestions of the novice: "What kinds of Pear Trees can I plant most profitably ? - and how sliall I treat them, to insure a return of the imvestment?"

'The Author has indulged no higher ambition than to answer these queries satisfactorily-and does not clain the alvility to instruct those experienced Pomologists, whose lives have been spent in patient investigation of the most minute plicnomena attending the l'ropagation, the De. velopnent, and the Fruiting of the Penr 'Tree.

In constant communication with Horticulturists, the wint of a Minual of Pen Culture, so often suggested by them, originated in my mind the iden of collating the experience of the hest cultivators; and stimulated by my own liestrty lore of the subject, I have executed the work now offered to the lovers of that noble fruit.

If it shall result in a more intelligent treatment of the locurtifil lut dunl, companions of the IIorticulturist, and thus olviate much of that disappointment which has flotrenl fiom igurance of the peculiar requirements of the Pesm J'ere, and of the vardeties to be selected, the Book will hate performed the ofliee for which it was written; and the Antlior will not regret his work. 


\title{
C 0 N T' E N I' S'.
}

\author{
PAPT I.
}

Prepuration of the Soil-Draining-Plowing and Cropping the Gıound -Trenching-Manuring-Digging Holes-Digging Trees-Soils for Pears-Transporting.

\section{PART II.}

The Seedling-Planting Secd-Obtaining new Secdling Tarietics-Uybritizing - Lcaf Blight of Secdlings-Propagation by Layers and Cuttings-Quince Stocks-Cost of preparing Ground and PlantingManures for Nursery Stocks-Methods of Grafting-Budding.

\section{PART III.}

Selecting Pear Trees from Nursery-Causes of the Failure of Nursery Trees-Proper Age for Planting-Pruning and Root Pruniug beforc Planting-Replanting the T'ear to form Fibrous Roots-IIceling inTreatment of Withered Trees-Pluting-Plan of arranging I'ar Grounds-Cultivation of the l'ear Orchard-Mulching - Special Manures for the Pear-Invigorating Old Trees-Grating Large Trees.

\section{PAI.T IV.}

Office of the Quinen-stoek-Canses of the fililure of the Pear on the Quince-Idvantige of the Quince Stock-liules for Growing the Pear on (quince-1)ouble Working. 


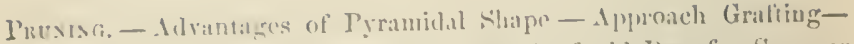
Irunine (1) a but-liemening the Wood of old I)warfs-Summer l'inching-liruit sinrs, and T'reatwent-Jions of Training-linles lior I'runing-lioot l'runing.

\section{$P \perp R T Y$ T}

Juskask of tuf Prar. - Winter or Frozen-Silp lilight-sigus of the Distase-Insect-lilinht-leat-lilight.

\section{TAliT VII.}

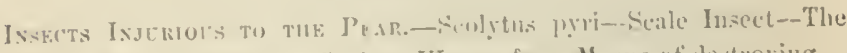
Pear Slug - Cateruillar, Canker, Worm, de._lleans of destroying.

\section{PAIT VIII.}

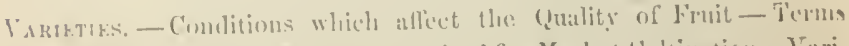

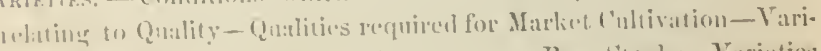
ctive for Marlię cuitivation to be grown on P'ar Stocks-Varicties that may be grown on the Qunee.

\section{P I R T I T.}

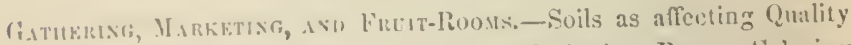
of Jeas-Thinning l'ruit-Gathering-Warketing Pears-Coloring and lipening of Sulmum and Autumn l'ears-Ripening of lVinter

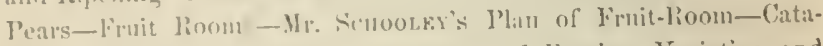
Ingue of Sative Vurietic-Catalogue of loreign Varieties and symonyms. 


\section{PEAR C U L T UR R.}

\section{INTRODUCTION.}

WHILE revolution and conquest were disturling tho equilibrium of the political world, during the last twenty years, bringing dread and terror in their sanguinary train, another revolution was progressing, more enduring-as it was productive of happiness, instead of misery.

This was, the revolution in the culture and production of everything which the gencrous carth yiclds to man's cultivation; but more particularly manifested in the propagation and perfection of truits.

Our fathers required the whole of their long lives to eat of the fruit of the tree they planted. But by the new arboriculture, the youth may pluck fruit from the tree he planted when a child.

In mone of the fruits is this peaceful retolution so striking as in the culture of the Pear. From the loug period of twenty or thirty year's required for the firuting of the tree, we have deducted more than fonrtifths, and reduced the time to three or fomr.

The introduction of the French methol of propitgation upon the Quince stock late given such in 
impetus to the cultivation of the Pear, that the sales from a single nulvec $y$ in this comntry reacl the cnormous number of half a million trees in one year. It is mulubtedly true that the propagation of the Pear on the Qunince, by its early production of this noble and beatiful fruit, will be the source of more malloyed pleasure, and more innocent and healthtinl gratification, than any discovery in the arts and sciences for the last twenty years.

The origin of this method of propagating the Pear munt not be looked for in very reecnt times-as trees more than a lumbed years old, originally upon the quince stock, may be foumd growing in France. The history of its introduction into this comntry wonld not be difficult to trace; but I lave been able only to asecriain suflicient to induce me to believe, that Mr. Prenkxs, of Boston, was among the first to introduce it, nearly forty years since; soon after, Marsmale P. Whamide of Buston, and Mrr. Mraxing, of Salcm ; and latter still, Mrr. Hortst, of Cambridge, eommenced the cultivation of quinec-rooted pear trees, which may be seen in those places more than thirty years of age.

M[r. Maxtel, of Astoria, was for some yealrs in opposition to Mr. A. J. Dowsisg, the earliest arlyocate of its general cultivation; but it was not mitil within the last eight or ten years that the planting of the trees lad hecome very common. Indeed, it is only within a year or two hlat the theory was hroached, which governs the whole constitution of the conpound tree, viz.: that the offiee of the Qunince is cutirely as root, and not as a trunk.

'lhat we shall anrive at a proint of excellence in tho 
propagation of the Pear which will euable us to dispense eren with the Quince in great part, is not doubted by good pomologists.

In the original introduction of the Pear as a fruit into this comntry, the French Hugnenots bore a pro. minent part. In preparing for their exile, they donbtless selected the seeds of their best varieties, and planted them around their homes in the New World. This is evidenced by the multitude of aged trees (many of them producing fine varieties) in the immediate neighiborhood of their first settlements, particularly on Long Island and at New Rochelle, in Michigan and Illinois.

It is not a little curious to observe low the taste and preference for this fruit has survired in the comtries through which the Huguenots passed in their flight, or where they temporarily sojomrned. Belginm and Holland have prodnced more fine varieties, and more eminent cultivators, of this frnit than all the rest of the world.

There are many questions relating to the Pear, which are still little understood, although discnssed for a long time by men of talent. Among these are: the decline of certain highly-esteemed rarieties, which can no longer be grown in localities where tley formerly ranked as the highest and best; the excellence of many rarieties in particular places, and their inferiority when grown in other's; the refusal of some varieties to grow upon the Quinee stock.

These, and many other mysteries, which have cansed as much disappointment and changrin to the enltivator, from his inability to account for them, as from his 
failure (1) ohtain the fruit, eannot, from the limited character of this wo"k, be discussed at length. The Pear has proved, by experience, to be adapted to as wide a range of territory in the United States as the Apple; and on the lighter soils of the Atlantic coast, to be much more productive. Tre are begimning to learn, too, what varieties are adapted to special localities and soils; and amid the great multitude of excellent kinds, it will not be dificult to find some that will sueced, with ease, in the most unfarorable location.

We are not confined now, as formerly, to a single variety, that ripened in Angust or September, whose eranescent excellence ranished in a day or two; but by a skillful selection of varieties, we extend the cujeryment of this king of f'uits orer a period of eighti or nine montlis - or from August to May.

A great adrance has also been made in the quality of the fruit; for in place of the dry and mealy SugarPear, the insipid Jargonelle, and the sriping WinterBell, we have obtained the Flemish lieanty, the Duchesse, and the Easter Benrré.

That we shall continue to make great progress in the knowleilge of rarietice, their propagation and improrement, can liardly be doubted, as long as such intelligent and enthusiastic men as Downwa, Wrumen,

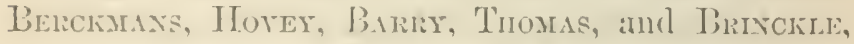
continue to cultivate the Pear. To them the pomolngrists of this commtry owe a large deht of gratitude; and to them I am inderberl for much that is valuatiln int this treatise. 


\section{PART I.-PREPARATION OF THE SOIL.}

To the tree-planter, the author would say, in the commencement of this treatise, as its most important and best fortified proposition: that the most complete and thorough preparation of the soil is by far the most economical and productive.

Let none, therefore, be deterred from its performance by the labor of preparation, as its neglect will perpetually remain a source of 'regret. Defects or neglect in this matter can never be entirely remedied by any futmre mursing or manuring. The thorough pulverization, deepening, and mixing of the soil before planting, will insure a healthy and vigorons growth, which the best subsequent system of manning, trimming, and cultivation, can never equal.

The satisfaction and delight that one feels in growing a beautiful tree, are enhanced by the knowledge of having been the instrument in supplying a soil and cultivation intelligently adapted to its perfection.

The nurseryman is called upon to answer no question oftener than the verations query: "How large holes shall I dig for planting my trees?" It can only be answered wisely by saying: "If you hare one hundred trees to plant, dig but one hole for them all- 
in other words, dig the whole field as thoronghly as you wonld the space for at single tree. If treeplinters would observe this rule, few of them mould suffer the disappointments which often attend transplanting. So few persons, howerer, can find conrage to invest this amount of labor in the mere planting of a tree, that it is a little to be feared that some will be disinelined to attempt anything, when so much is demanded for perfection. To such it can only be said: "Undertalie less than you intended, but perform that little in the best manner."

The processes for the important work of thorough preparation of the soil are: tirst, Draining; second, Plowing and Cropping the Ground; third, Trenching-fourth, Minmring.

\section{IDIALING.}

Thorough drainage has become so much a matter of faith with intelligent agrieulturists, that it is con sidered almost heresy to doubt its ralue or necessity in all soils.

Witlout questioning the truth of this extreme doetrine, it is sufficient for us to say: that all soils, possessing any of the following conditions, must, to secure a liealthy growth of the pear tree, be first thoroughly drained.

1. Those composed prineipally of clay.

2. Those which rest on an impertions subsoil.

3. Those generally upon which water remains moro than an hour after rains.

4. Those in which springs, or springy ground ap pearj. 
5. Those which lie at the base of a hill at some distance below the summit.

6. Those which lie so nearly level that, although porous in their eharacter, do not allow the water to flow off readily from the surface.

On any of the varieties of soil mentioned, without draining, the pear tree is peculiarly subject to scrious disenses. The winter or sap blight finds its most numerous victims upon them, while in the worst con. ditions of such soils the growth of the tree is slow and stunted. In soils at all retentive of water, thorough drainage is the only safeguard against these evils, and many positions, not suspected of this defect, will be found upon examination to be sadly in need of this remedy.

If the plot of ground lies at the base of a hill, or on its slope, at some distance below the summit, the water percolating through the soil from the ligher ground will find its way to the surface along some saturated strata; and the least that can be done will be, to cut a ditch of from four to fire feet in depth along the upper line of the ground, thus intercepting a part of the descending waters.

This ditch should be laid with tile, or a rude but effective channel made of rubble stone, and in botl cases should be half filled with the latter, when procurable; upon which a thick layer of straw should be placed, and the earth pressed firmly in to fill up the ditch.

For more inimute directions relating to the conditions of soil requiring drainage, and the varisus 
methods of eflecting it, the render is referred to the works upon that subject. It is sufficient for this place to say, that there are but few soils that would not derive great adrantage from thorough under-draining.

\section{PLOWING AND CROPIING THE GROUND.}

When the planting of an oreliard can be anticipated for a year or two, the ground should be prepared by growing some hoed crop upon it; as the proper treatment for a good crop of corn, or potatocs, forms an excellent preparation for the growth of trees. By this plan, the soil is redueed to a fine tilth, the weeds are sublued, and if the erop has been well manured, the ground is rich enough for the first year. If the soil is clayey, or otherwise retentive of moisture, the plowing should be performed in the fall, and left in ridges; but if at all sandy and light, it should be left as compact as possible at that time, and not plowed until spring.

The ground should be double plowed, by turning a deep furrow, and following in the bottom of that furrow cither with a subsoil or common plow. If there is sucl a thing possible as stirring the soil for eirghteen or twenty inches in depth, it should by all means be accomplished, for this reason : a hole dug in a soil, more or less compact, is in eflect a cistern. This, while it loses capacity, does nut lose any of its power to retain water, ly being filled with loose eoil, in which a tree is planted. The invigorating efiect of water upon the roots of plants is probably nearly exhausted in the first few moments of its con- 
tact with them, and becomes less and less valuable, the longer the same particles remain, until it is a cause of absolute injury.

If the hole, therefore, is dug deeper than the surrounding soil is loosened, the lower part of it will retain water for an unhealthy action upon the roots planted in it. But if the earth is loosened over the whole field, as low as the bottom of the deepest hole, the drainage from that hole is perfected, and the otherwise stagnant water will flow off, provided an outfall from the field is secured.

An excellent plan for those who are pressed for time is, to plow fire or six furrows, twice deepened, or subsoiled, in the line where the planting of a row of trees is intended, and omit the intervening spaces until a later period. Let these furrows be s'm, if possible, in the direction of the slope of the ground, to aet as drains.

Those horticulturists, however, who intend performing their work in the most thorough mamner, should talie this rule as their standard.

Pulverize the soil of the whole field to a depth greater than the longest roots will be planted, and this can only be well done by

\section{TRENCIILYG.}

As frequently performed, the best results of trenclling are not attained. 'The true design of its performance is, to add to the depth of the soil, withunt destroying its capability.

When the fertile earth near the surfice is thrown 
In the botiom of the trench, and corered ten to twelve inches decp with sterile suil, which has never been acrated by fiequent stirring, in contact with the atmosplicre; citlier a very large quantity of mamme must be applicel, ol, with ordinary treatment, some Years must elapec, before the soil cau become fertile, or capable of sustaining trees in a lienlthy condition.

A trench, two or three fieet wide, shonld be dug to the proposed deptli, across the end of the ground designed fior trenching, and the earth deposited on the side of the ditch opposite to the space intended firl treatment. The soil thrown up should now be dressed into an easy slope, so that otlier carth cast upon any part of its face will not fall to the bottom of the trench, but remain where it is placed.

A single spade's-width should now be talien from the surface soil, and scattered evenly over the sloping breast of loose carth, forming a layer of three or four inches in thickness, finm the bottom of the trench to the top of the bank. Orer this should be thrown the next spade's-depth of subsoil, forming a somewhat thicker layer; and this again is to be covered with patt of the arljoining surficc-carth; and lastly, over this is plareed the third spate s-deptle of subsoil. 'The buttum of the trench may now be simply loosened by the spalle, without thowing up the carth, muless it is determined to trench deeper than two fect. The manure to be used slonld now be sprearl evenly, so as to form anotlice liyer fivm the qup to the bottom of the sluping hank, ambl the alternate stratiz of fertile carth, batreu subsoils, and numure, continued to the cill. 
The object to be attained is, so thoroughly to mis, as well as pulrerize, the two soils thrown together, as to dilute the good earth with the inert; but it will be perceived, that they have only interchanged positions: without commingling.

The layers of soil and manure declining at an angle of about forty-fire degrees, and which now cxhibit their edges at the surface, may be thoroughly interrningled by one or two deep plowings. It will at once be seen, that a soil deepened in this manner will demand much more manure than when eultivated to the ordinary depth.

When the trenching of a plot of ground is finisherl, a ditch will remain, which must be filled with the eartlı first thrown out at the other extrenity of the field.

The cost of trenching an acre of ground will depend greatly upon the character of the soil, and the depth it is worked.

The trenching of my own ground may not afford a fuir criterion, but it will furnish a hasis by which calculations may approximately be made of the expense.

The soil was a sandy loam, deepened to an arerage of nearly three feet, with the surfice earth of the adjacent streets, and though rery free in its composition, liad been rery much hardened by the prasage of the carts in filling.

I.ABOR ON ONE ACRE-TREACHED THIRT IXCHES DEFT.

Plowing, one day........................ $\$ 300$

Seventy-two days' labor, at $\$ 1 \ldots \ldots \ldots \ldots \ldots \ldots \ldots \ldots$ i2 $(x)$

One day earting soil from the first trench to the last one, 2 men 3 mo

Removing etones thrown out.................. 10.0 
From some comparison of the amonnt of labor lipon whlicr grounds, I an convineed that the above would prove nearly an average cost, altlough the trenching of heavier and more stony lands would cost as much as 100 per acre. Where the labor of preparing an acre at unce, appeared too formidable a task, a number of amatems lave practiced the following plan at my recommendation with grood results.

The ground intended for planting is divided into lour equal parts; and if the whole plot contains an acre, and is a square, each fourth will contain almost 11,000 superficial teet, and its four sides be each 10.5 feet in lengtl. A more convenient plot. fir spacing the trees accurately, would be, 100 by 110 fect. Extending these lines to 220 feet by 200 ficet would inclose but a trifle more than an acre.

One of these quarter-acre plots shonld be thoronghly trenched and mamured, to receive all the pear trees intended for the entire acre. None of these trees need be remored before the end of the second ycar, when another plot has been prepared for the reception of every alternate tree in each alternate row. $\Lambda$ the end of the thind year, another square laving becn trenched, remove every alternate tree from the roms, which at the last removal were untouched. 'The originatl square will now contain one half of the whole number of trees, or double its qurota ; and the removal of crery alternate complete row to the fourth mocenpied square, in the fourth year, will place the trees at ("fual distinces lhoughont the entire grouad. Somewhat more than thr cxict mumble of trees necessary to complete the plim shombl be planted in the first 
year, in order to be able to compensate for the loss of any, by substituting trees of equal size and rigor.

This plan presents advantages which will be more largely discussed, but of which the following is a synopsis.

1. It divides the labor into practicable portions which do not discourage the planter by their magnitude, and the work is better performed than if more were demanded at once.

2. Manure, which would be difficult to obtain in sufficiently large quantities, for preparing the whole ground well, may be easily procured for one-fourth the area.

3. In the best selected lot of trees, there will, from various eauses, be some that fail in the first two or three years, and if planted in an orchard, would leave an unsightly blank-or require the planting of a tree that will always break the harmony of the ground, by its smaller size. But trees taken from the near supply will scareely lose any vigor, by a careful second transplanting, and not one in a thousand shonld be lost.

4. The root-pruning oceasioned by remoral hastens the bearing of pear-trees, on both pear and quince stocks, many years.

5. All the nursing which young trees especially require is brought within a small compass, and the labor is materially lessened. The mulching, the hunt for insects, and the washing of the trees, are all performed in a small area, and without the fatigning lator of travelling long distances. The pear tree, abore all others, is especially fitted for frequent remorals, and 
is, indeed, bencfited by them in acquiring eapacity for early fruiting

\section{MINTRING.}

['nulonbtedly, the most thorough preparation for an orchard or fruit ground wonld require the enriching of the whole soil nearly as well as most cultivators do the space immediately around the tree. As it is intended that the entire body of earth within the limits of the fruit ground shall be occupied by the roots, it is important that it should contain suficient nourishment for their sustenance. During the first few years, it is true, they would be supplied with the pabulum they find immediately around the tree, and that in a light soil much of the nutriment at first supplied would have escaped betore the trees were fitted by age and growth for its appropriation. But for such a soil, the manure should be adopted to its peculiar condition, and be composted with a large bulk of clay, or swamp-muck, or other organic matter, which will enable a humery soil to long retain the fertilizing agencies applied to it. A soil, howerer, which has been naturally supplied with but a moderate proportion of regetable monld or clayey loam, will not forget for many years the influence of a manure which has been deeply deposited. Used in this manner, manure will exhibit its influence upon the growth and fruiting of the pear tree in a much greater degree than in any subsequent application. It not mfrequently occurs, that suflicient manme firr the whole space of gromul to be fertilized is not readily obtainable at the time of planting. 
To economize the quantity for present use as much as possible, a partial application, that will serve temporarily, may be made along a line of fire or six furrows in width, thoroughly plowed in, and intermingled with the soil. After the holes are dug along this line, well-rotted manure should be strewn in them, and corered with soil. Occasionally, as the hole is being filled over the roots, more manure should be well pulverized and shaken in, but in all cases, in such a manner as to prevent its direct contact with the roots. In deepening a soil for any purpose, it must be remembered, that as the quantity of earth to be enriched is greatly increased, a much larger amount of manure will be required. If it be desired to increase the depth of a soil of nine inches to eighteen, and the manure is thoroughly intermixed to that depth, it will require more than donble the quantity of the latter, which would be needed to fertilize the first nine inches of depth, as the subsoil is nearly devoid of nutritions matter. But, as the escape and loss of this is upward into the atmosphere, the deepened soil will retain the volatile constituents of manure much longer than a shallow one.

\section{MANURE FOR PEAR-TREES.}

It is a general truth, that the manure that will produce a good crop of corn or potatoes will perfect a crop of fruit; but while special manures are to be jealously criticised and tested by experiment, still something should be learned from the special demands of the plant. In the ashes of the pear and apple wood or fruit, and in the potato stalk and tuber, a very 
largo amount of potash is found, and the theoretical deduction from that fact, that potash or ashes would add largely to the growth and fruiting of these varietics of trees and plants, is found true in practice. But in the ashes of wheat, comparatively little potash is discorerable, while in its place is seen a large amount of phosphates; and, accordingly, we find the various salts, of which phosphoric acid is the base, exercise a great influence in increasing the wheat crop. Now it would be blindness or mulish obstinacy to neglect these facts, and apply manures without attention to the special wants of a plant or tree. Farmers and gardeners who scout contemptuously the teachings of science in regard to manuring, daily practice the most scientific and special theories for manuring plants, to produce perfect vegetables and flowers.

Well-rotted stable-manure is without doubt the safest, and ordinarily the most convenient, form in whicl nutriment can be conveyed to trees, but it is not always attainable in sufficient quantities, nor docs it alone produce the highest result. Guano is a convenient manure, though temporary in its action, unless combined with twenty times its bulk of charcoal-dust, plister, or partially, dried muck. From two onnces to half a pommd may be applied to each tree at plantingr; varying in quantity according to the area and depth of ground in which it is distributed. But in no case should it be placed so that the roots will have less than three to six iuches of earth, protecting them from its canstic inflnenec. Guano affords an admirable liruid-dresing for trees (especially when exhibiting a languirl growth) applied at the rate of an ounce or 
two in a pailful of water, distributed for a space of three or four feet around the tree.

Of the more concentrated forms of manure, ground bones, horn slavings, etc., are decidedly the best, especially when dissolved in sulpluric acid.

When used without this treatment, the bones should be a mixture of the finely-ground bone-meal and the crushed half-inch bones in equal quantities. The first will decay rapidly, and afford immediate nutriment to the roots, while the latter will last longer, and yield their virtues when the finer bones will be completely exhausted. But even these generous and excellent manures have a better effect mixed with coarser manures, such as stable-litter, horse-dung, swampmuck, and other decomposing organic matter.

Summer applications of stimulating manures have a tendency to produce late succulent growth that does not ripen, and which the winter blights or kills down, endangering the life of the whole tree with its poisoned sap. Late spring applications of manures also stimulate wood-growth to such an extent in midsummer, as to induce the tree to throw off the young and half grown fruit.

In the grounds of the author, during the last scason, a Bartlett Pear tree, three years from the bud, set 520 pears. When the fruit had acquired the size of musket-balls, the tree was supplied with guano and superphosphate of lime, dissolved in large qunntities of water, in order to ascertain low great a number of fruits a tree six feet high, and one and a half' inches in diameter of body at the ground, would inpenl. A barrel was filled with the solution, and set so as to leak slowly about two quarts daily around the roots. 
As the summer adraneed, fine thrifty shoots, two and three feet in length, covered the tree, but all the fruits, except about thirty, fell before ripening: while on trees not stimulated by such munatural nutrition, and which made little or no wood-growth, more than fifty fine pears were matmed.

No tree of that size should have borne one-quarter of that number, but it was an experiment in which the grood of individual trees was not regarded. Nature usually refuses to perform the double labor of woodsrowth and large fruit production during the same period; and we cannot, with all our skill, induce her to disregard the laws which goveru her delicate and wondrons processes.

When rich stimulants are applied to bearing trees during the growtl of the fruit, the latter is almost certain to fall prematurely, as soon as the unusual mutrition is exhibited in more thrifty production of wood-nrowtle.

The proper time for the application of sucl highly organized manures as have been mentioned, is in the fall or in carly spring, during the libernation of the tree. They should always be well and deeply worked into the soil. The cost of numuring varies much with the locality and price of stable manures. If thoronghly manured fur the reception of 400 to 800 pear treesan acre slonld receive from twenty to fifty domble wagrou-loads of stable or compost manmes. Thirtyfive wagron-loarls, at two dollars eacle, would fix tho cost of manuring an acre at sito, which would be a very moderate sim.

in the grounds of Prof. Mapes, at Newark, New 
Jersey, may be seen pear trees of luxuriant growth, producing great quantities of the finest fruit, which have been mannred, as he assured me, only with superphosphate of lime.

COMPOST.

There is nothing in his range of labors that gires the genuine lover of fruit and vegetable growth such complete satisfaction as the increase in size and excellence of his compost-heap. In it the cultivator is storing up his chemicals for Nature's laboratory, and is thus prepared to furnish to her the elements which shall come forth the purest gold. Untold wealth lies hidden in its dark and unseemly mass, and at the magic touch of the great enchanter, shall burst forth in forms of wondrons beanty. In it his imagination sees hidden the subtle essences which will ripen the golden pear, color the cheek of the melting peach, give lustre to the green foliage and beantifin growth of the trees on which his care is bestowed; and thus he cheats his senses of the loathsomeness which appears to others.

No single substance or kind of manure contains all the virtues or manurial requisites for tree or fruit growth; and a compost which contains all or most of the fertilizing agents, will be always found in practice to produce the finest growth and fruit.

Excellent results in the growth and fruiting of pear trees have been obtained from a compost formed $n$ the following mamer: Peat or swamp muck, and the tough sods of an old healland, were laid down in is layer about six inches thick, and twenty-fire feet 
seyuare, and on this a lityer of old leather shavings, three to finr inches, and an inch of refuse lime were Hacel. These layers were repeated until the heap was tive or six feet in heighlat. To every second layer of sorls or peat was added one inch of bone-meal, amounting to one hundred bushels in the aggregate, and twice on the top of the sods a layer of six inches of horse manure, that aided in starting the formentation. The whole was encased and topped off with sods. $\Delta$ narrow rim was turned upon the ellge, forming a basin, and five lumdred pounds of potash, dissolved in water, poured upon the heap. If ashes latd been obtainable, one hundred bushels of unleached, or three hundred to tire hundred of leached ashes wonld hare been applied. The heat, contained one hundred cubic yards, was turned twice hefore spreading on the soil, and was intended more as a medium of distributing the potash, lime, and five hundred pounds each of guano, and superplosplate of lime, afterwards added, and for forming with the peat and leather shavings a good retainer of ammonia in the soil.

Let every fruit-raiser, each spring and fill, prepare such a compost as the follewing, and the results of its application to trees will astonish and delight him.

$\Lambda$ licaj of leaves, leat' or swamp muck, peat, or

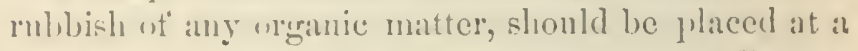
ennvenicut distance from the lonse (for no offensive surell need be apprehended, if properly treated), to receive the wond-ishes, the soapsuds, the kitchen and eliamber slops.

Another heap should be formed at the stables, or rather, a pit should be ding, and half filled with tho 
absorbing materials, in which should be thrown all the bones and spoiled meat, the carcases of fowls and animals, all the old fish and meat brine, the nigrhtsoil from the privies, and the liquid manure from the stables. Eren the coal-ashes should be preserved for the small per-ecnt of alkaline salts they contain; and to the whole, iron should be added in some shape, either as cinders from the blacksmith's shop or the foundry.

All this mass is effectually deprived of offensive smell, by covering with a fresh supply of muck, whenever an escape of nitrogenous matters is perceived. The effect of such a compost, applied to firuit-trees, is almost startling, in the rapidity and hardiness of growth it induces, and in the luscious and highly. colored fruit a soil so fertilized will bring forth.

As the dark and loathsome mass swells in its proportions, the cultivator (who knows it is but the ungraceful form which corers a beautiful soul) sees gorgeous flowers and fruits emerging with colors no mortal hand could bestow.

\section{DIGGNG HOLES.}

If the soil has been trenclied or deeply plowed, the digging of holes for trees is a work of comparatively small labor, and they need be made but little larger than sufficient to accommodate the roots without bending or erowding. When, howerer, the soil has not been thus deeply prepared, the holes should be dug as deep and as large as the most generous views of the planter would dictate, taking eare, only, that they shall not be a less width than twice the diameter 
of the spread ronts to be planted in them, nol $^{\circ}$ of a less deptly than six inches below the bottom of these roots.

When it is intended to prepare the ground only in the immediate vicinity of the tree, the holes should not be less than fomr feet in width, by two feet in depth. But no plan can be more defective than digging deep holes in retentive clayey soils, where water will cullect withont fiecelom of passage. Filling this hole with loose earth does not alter its character for retaining water, and the roots must soon decay. When it is only intended to dig such holes withont connecting them one with another in the form of a trench, laving an outlet fiall, the planter liad fiar better digr but a shallow hole, and prepare himselt for very indifterent results without more pains than mere hole-digging.

\section{DIGGING TIRELS.}

The disappointment and chagrin which the treeplanter fiecls at seeing a sickly tree linger fiecbly through three or tom seasons of yellow leaves and dwindling lianches, would often be arerted if some person interested in the life and growth of the tree, and with skill to direct, were present at ats diegring.

It is just at this print that the care of the cultivator should begin, tor it is too late for skillful management, when the tree lias been ruined in the digging.

To disiplunintment can be more exasperating than that experienced hy one who wats with fererish impaticnec, year after year, for the fruting of his trees, and sees them stlugerle, almost like living sentient tuings, to preserve at sichly existence, and ultimately 
die from the violence and abuse they receired in dis. placing them from the nursery. Many a person has retired care-worn from business, to the farm he has labored half a life-time to obtain the means of purchasing, only to be driven back into the old mill-track again, by disappointment at the result of his labor in planting the imperfect, rootless trees sent to him from some famons nursery. The nurseryman is usually sincerely desirous that his trees should be taken up carefully, and arrive in good condition; but petty questions arise regarding the expense of increased labor in digging or packing carefully, and his reflection usually is: that he "guesses they will do pretty well." In pressing seasons, too, he is glad to eugage the most ignorant foreigner who offers; to be cmployed in digging up a tree, about whose necessities the laborer knows no more than lie does of the constitution of the country of which he is, or expects to be, a roter. Pat or Ileinrich, with no ligher idea than that lie is to take out a good spadeful, sets in his spade close to the body of the tree, and by lifting, and prying, and twisting, brings out a living thing from the earth, which although mangled, and torn, and ent, he cannot conceive is hurt, because it does not groan.

It is not only stupidity and ignorance with which the purchaser is obliged to contend, but an ntter indifference on the part of the laborer to the sncess or failure of the tree; and his desire to exhibit a good day's work induees him to liasten that part of his labor in which he shonld exereise most care.

In all cases, one should begin with the intention of hastening no part of the digging of a tree which can 
be better done with more time. If the tree is more tham two years old, commence at a distanee not less than two feet from the body, and increase the distance one foot for every inch in thickness of the tree at the eartli-collar. Set the spade into the ground with one elge of the mpright blade always turned towards the tree, and bending back the spade, raise the earth with a slaking motion, that will free it from the roots raised by the blade. If the flat side of the blade and the fitee of the digger were tumed towarls the tree, every root would be ent off clean, where the sparle enters the ground. But by the first method, in addition to the two feet of roots in the solid ball, there will remain rootlets and fibres to the width of the spade.

In this manner proeeed around the tree, with the edge of the spade tumed towards it, and yon will cut very few of the roots which extend into the trench.

Let a sharp entting spade be provided, which should never be used for digging, and with this ent smoothly all the roots that extend beyond the trench until the lowest layer of roots is reached, and proceed to dig muder them, by laying the spade nearly 1lat, and parallel with the ground, and fhrusting it muder the ball to ent the tap-root. IIaving cleared away the loose dirt, shake the tree gently back and forth, until it is asecrtained where the tree is held by the remaining ronts; and then, with a digging-fork, dislodge the carth in the ball from them, and only lift it when you find that the tree will not strain, or the roots lreak.

A gentle shake will mow tree it thoroughly from carth without dashing it against the gromed, as most 
laborers will do unless watched. From this time, the sooner it is in the ground the better; but if replanting is delayed, Nature inust be imitated as nearly as possible, by hiding the roots from the light and air, in the best manner, and as soon as you can. An old rug, pieces of matting, wet straw, or, when these are not convenient, a light, but complete covering of pulverized soil, should be thrown over the roots.

Even in a rainy or cloudy day, injury is received by exposure to the chilling atmosphere or light.

When the soil is sufficiently adhesive, and the trees to be planted are near their destination, a ball of earth may be left around the roots, and the whole carefully lifted in the arms of two men, and set in the hole.

There is in plants a condition somewliat analogous to animal heat, thoughl hardly sufficiently well defined to be pronounced vegetable leat. But it is certain that the temperature of plants must be maintained within a linited range, to preserve their juices from destructive change; and this linit is much restricted, when the roots are deprived of their natural protection, and exposed to chilling atmosphere. It is not necessiry that the temperature of the air should even be lowcred to the freezing-point, to accomplish great injury to the naked roots, which, while protected by earth, could endure an absence of heat indicated by thirty degrees below zero. There is something in this analogy of condition of plants to living beings which, while it excites our wonder, reveals to us how little we have yet learned regarding their mysterious processes.

I have seen some of the roots of at pear tree, stand- 
ing upon a bank, exposed on one side entirely unprotected, to a serere; winter, without injury. The requisite condition, or leat being maintained by their comnetion with the larger body of roots, which were protected in the soil-just as we daily cxpose a part of the person to the cold with impunity, while the naked body would not endure a temperature many degrees higher, without perishing.

There is an equal danger in exposure to the opposite extreme of temperature, though not so rapid in its consequences. A cold bleak wind is fiar more eflective in drying up the sap than a moderately warm temperature, exerted fur the same length of time. The eflects of both cxtrenes of heat and cold are the same. 'The sap is inspissated to such a degrec, that the empty cells close up, and become incapalble of again excrting the inysterious cullosmose action by which their finetions are employed. Conld the lungs of a drowned person be once more inflated, the blood would commence its flow; or conld the blood be induced to move by friction, the empty atr-cells of the lungs would fill, and the rital functions of life once more crommence. Could wo fill the collapsed sap-ressels of the dried tree, we should gain une point in its recovery, and in the alpropriate place the means for this will be diseussed.

SOILS TrOIR I'JARS.

It is somewhat mortifying to the promologist, after twenty years of earefinl study of the laws which govern the growth and fruiting of trees, to feel con- 
strained to acknowledge, that not only what lie lias learned from others, but much of what he has gathered from his own experience, is to be distrusted-perhaps unlearned.

In nothing is he likely to be more disappointed than in the soils which analogy and theory would induce him to point out as superior. So many influences and conditions affect the results of horticultural effort, that disappointment often follows the selection of what appear the finest soils. The Newtown Pippin, on the soil of Long Island, where it originated, refuses to yield the exquisite juices and rare perfumes which distinguish this king of apples; and from the same island which once sent forth sloop-loads of the rarest Vergalien Pears, scarcely a bushel of perfect fruit of that variety has been gathered in one scason for the last fifteen years. Neither the richest soil, nor the most careful cultivation, any longer produce grood fruit of these varieties; while on the rugged fimms along the Hudson, the Newtown Pippin preserves its superiority with scarcely an attempt at cultivation bestowed upon it; and through the central and northern counties of New York, the Vergalien continnes to produce its nurivalled firuit. Most of the other varieties of Pear are prodneed on Long Island and in New Jersey in great excelienee and abundance. Varieties of pears are pronomecl execllent in the ricinity of Boston, which are worthless when raised in other localities with equal care in cultiration. These annnalies prevent us firom declaring with certainty upon the titness of any soil for all varieties of pears, when that particular locality and soil have not been tested 
by experiment. No prudent man will, therefore, plant a very large number of trees, of varieties which have not been proved in his neighborhood; at least, not without having made careful inquiry regarding those that have suceeeded or fitiled.

Still, general rules that should govern in the choice of suils may be giren. No soil, howerer rich, that allows water to remain on its surface more than a day after it has fillen, or to rise in looles dur not more than four feet decp, is fit fur plantations of the Pear, or, indeed, of any other fruit tree. And no light, thin soil, which is not susceptible of deepening, can be relied on.

The soil for the Pear must be dry, and either deep, or capable from the nature of its subsoil of deepening without destroying its excellence, and of a looseness of texture suflicient to allow the firee extension of the tender rootlets.

A peaty or alluvial soil, or one ton rich in vegetable mould, may induce a lnxuriant and beautiful growth in appearance, the succulent shoots of which a rigorous winter would certainly blight. A free loam having a large preponderance of sand, withont being light, is preferable, as it is easily worked, at times when a clayey soil would be nearly a bed of mortar. With proper manuring the first would produce a stocky, well-ripened, but comparatively short growth, while the latter, if in grood condition, would induce one more vigorous, but fiequently unripened.

$A$ noticeable instance of this difference is seen in the fact, that the winter lilight of the Pear has never been known on the rich, but light soils of New Jersey 
and Long Island, which seem peculiarly adapted to the growth, productiveness, and longerity of the Pear; while the winter of 1555 destroyed many thousands of pear trees on the strong soils of the comnties of Central New Tork. In the neighborhood of Syracuse, this was especially remarkable.

Nothing ean be more fittal to the hopes of the pear grower than the selection of his trees from an alluvial flat. Blight at some period of their existence is sure to manifest itself in a great number of them. Free soils, however, it must be granted, are subject to balancing evils, in affording shelter to inmumerable tribes of insect depredators, in fostering the produetion of equally innumerable varieties of weeds, and in more readily parting with moisture and manure.

A more nearly perfect soil as a base, for the cultivation of the Pear, is a somewhat heavy loam, composed of three-fourths of coarsely granulated sand, fifteen to twenty per cent of clay, and the remainder of vegetable matter. This'should rest upon a subsoil of sand and clay, extending to the depth of three or four feet. A bed of gravel should underlie the whole, thus aftording perfect under-drainage. It would be well for the planter, before engaging largely in the business, to ascertain the longevity and productiveness of such pear trees as are growing in his neighborhood. Many of the old Dutch residences of Brooklyn, erected long before the Revolution, bearing evidence of the military violence of that period, are surrounded by trees older thim themselves-trees that have outlived two or three generations of houses, each of which may have seen as many generations of men pass away. 
Mr. Downing certainly made a great mistake when, in writing a description of the soils suitable for the Pear, he pronouneed a sandy loam unfitted for the permanent grewth of the tree. Two or three homrs' ride through the western end of Long Island would have convineed him that there were, in that locality, more pear trees, from fitty to one hundred years old, than in all the rest of the United States. The number of pear trees, more tlian forty years old, in King's and Queen's counties alone, must be greater than fifty thousand. At Greenpoint, L. I., now the Serenteenth Ward of Brooklyn, may be seen an orchard of more than one hundred pear trees, which the oldest residents remember to have been of full size, and in full bearing, in their boyhood. 'Three of these trees I have found to measure respectively nine feet, ten and onehalf, and eleven feet in cireumference. These last camnot have been in existence less than one liundred and fifty years.

These were the ofl'spring of seed planted by the Dutch and Hugnenot exiles, about the time of the settlement of the town in 1645 ; and are certainly good evidence of the longerity of the Pear, on comparatively light soils. I do not assert, however, that trees planted on thin, sandy soils, especially such as orerlie an impervious, or a poisonous subsoil, * would not be liable to blighlit. On such soils, the roots, compelled to keep near the surface, are exposed to the sudden and extreme heats of summer, by which their sap is Eo highly lieated as to destroy the more newly-formed

- As is thu case, to a limited extent, In somo districts of New Jersey, whero the jrutusidu of iron-so injurious to vegotation-jirevaila. 
and tender spongioles and sap-ressels. In such case, the roots are said to be scalded; becanse, at their shallow position, they are unable to obtain sufficient moisture for the supply of the leaves, which, by their abundant evaporation, lower the temperature of the sap-vapor being so perfect a conductor of heat. The frozen sap-blight has not, within the memory of man, been known to visit the localities above-mentioned, except under the circumstances noted relating to subsoils.

TRANSPORTING.

Trees ought always to be packed, when the distance from the nursery to their destination is greater than can be accomplished in three or four hours; and, cren in the latter case, their roots should be well protected. Packing is a labor that most nurserymen would aroid, as the charge scldoin covers the bare cost of labor and material; but no man who values health and rigror in lis trees will grudge five times the usual charge, if its payment was necessary. Indeed, it ought to be a standing rule with nurserymen to charge such a price for trees as would cover the cost of packing; and then to pack them would be a matter of comrse, which the mistaken economy of the customer would not induce him to avoid.

Unless the purchaser has bought only a small number of trees, he should order them to be packed in boxes, that will endure the rough handling of freightmen, and protect them from bending, breaking, and exposure.

If trees are to be removed long distances in tight 
eases, they slionld be moderately dry, as if wet, or packed with very dimp moss, or straw, they are liablo to grow or to licat, and mould.

Straw and other coarse material should be distributed among the tops, and moss anong the roots, separating not only the layers of trees, but, as far as possible, the individual trees and roots from each other. When the transit is by water for a long distince, the moss should be dried, as sufficient humidity will be gathered on the passage; and the roots should be first dipped in a mortar, eomposed of elay and water, by which they will receive a coating of earth, which will protect each rootlet from the atmosphere. 


\section{PART II. - THE SEEDLING, AND PROPA. GATION OF VARIETIES.}

\section{THE SEEDLING.}

IT is surprising that so little attention has been paid to the perfection of the seeds which form the germ of the trees we so highly value. Pear seeds are peculiarly liable to prove defective, being gathered from all sources; and although they have recently sold at prices, varying from one hundred to two hundred dollars per bushel, there has not been a strict scrutiny as to their quality. The dealer cannot be too severely blamed for this, as no standard of excellence has been established by the nurserymen. The latter is intent only on procuring a large supply of stocks for budding, and as the results of inherent weakness in the stocks do not always manifest themselves in the nursery, he entertains but little anxiety about the source or defects of the seeds he plants.

After abundant experience, I am satisfied, that not one-half of the pear seeds sown regetate; and of those that do, not more than one-fourth produce healthy stocks, and that of the hundreds of thonsands of trees sold from the nurseries, not one in five reaches its tenth year.

Carelessness in transportation, ignorance, or indo- 
lence in planting, and neglect or absolute abuse in cultivation, are fittal to thousands; hut the indifference of the seed collector to the condition of health in the seed, equals all other causes in destructiveness. If the finit is mnipe, the seed must necessurily be imperfect, and the perry pomace is usually formed from fruit, of which but a small portion is pertectly ripe. The variety of pear from which seed is to be taken is nerer considered, except by amateurs; and as many of our varieties are known to be tender in their wood, tardy in their growth, or bally shaped, and short-lived, the fruit cracking or rotting at the core, the off'spring must be more or less corrupted by these defects. If allowed to remain only for a short time in the pomace or rotten fruit, acetons fermentation begins; and the seed commeneing to vegetate, the grerm is injured by the acid.

It must have been noticed that few seedlings make their appearance on ground where apples or pears have fillen, or been deposited after rotting in the cellar. while from the dung of animals fed on them, seedlingrs start from alnost every dropping; in the latter instance, all the fermenting acid matter of the pulp had becn appropriated in the economy of digestion.

Pear-seerls are injured, not only by being kept moist for a long time, but quite as often in the process of drying, and firom being kept ton dry. Large masses of moint seerls engendler lieat, but it the latter are exposel to constant atmospherical drying. the germ of miny of the seeds would hecome greatly injured. ?ear-seck, soon after being cleaned from the pulp, hould be separated from each other by some desie- 
cating material, such as sand, charcoal dust, \&c. From experience, we have found, that to obtain healthy seedlings for budding or grafting, the seed must be selected from healthy and vigorous trees.

In any part of a pear-growing country, there may De found large, rigorous trees, producing from ten to twenty bushels of small, well-shaped, but nnmarketable pears, having large and full developed seed-which fruit can be purchased for a small sum. These should not all be gathered at once, but at three or four periods -obtaining at each time only those that are ripe or nearly so. As fast as they become quite soft, the seeds may be pressed out and sifted from the pomace, and before beeming quite dry, or indeed they may immediately, be mixed with two or three times their bulk of the sand and charcoal dust, etc., and after drying for a few days be preserred until Spring. Much has been said of late about the adaptation of varieties to each other; that is, that certain rarieties of pear should be grafted upon those having the same habits of growth. But upon a large scale this is impracticable.

Some English nurserymen prefer the sceds of the Virgalieu, as they are large and full, and $\mathrm{M} r$. Berekmans has often told me that he has found all rarieties do well on the Virgalien stock. There is little doubt that the stocks produced from the seeds of the more advaneed and refined varieties produce fruit, when grafted upon, sooner than in inferior seedlings. Tut there is the serious drawback, that the finer varieties are shorter lived, and more subject to disease, than the Crab Pear, almost in the ratio of their excellence. 
From information of the use of a crab pear, in Con. neeticut, linuwn as the Perry, and from its great vigor, hardiness, and longevity, I anticipate excellent results from its nse as a stock.

After what has been said, it will be almost unnecessary to state that varieties subject to blight; or fruit from trees that have been injured by it, must always be aroided by the seed collector. One cause of defect and failure in trees is, the selection of suckers for stocks. It has been customary for some nurserymen, during the great demand for pear stocks, and their consequent scarcity, to employ the ragrant and wandering families of negroes to grub up the suckers in woods, and around old pear trees, for use in the nursery. Of the disadvantages attending the use of such stocks, it is hardly necessary to speak.

\section{PLANTING SEED-CELTIVATION OF SEEDLINGS.}

The seeds should be sown in October, after frost has made its appearance, or in early spring. The former is thought by many to be preferable. The conditions favorable to their growth, are the same as for the hest cultivation of trees. The soil should be deep, dry, well pulverized, and moderately rich. When grown in very rich or damp soils, they make a rank, luxuriant growth, but form excellent suljects for that pestilence of the Pear tree-the blight. Indeed, of all seedlings, not exotie, I think the Pear has generally proved the most difficult to grow. If the soil should be poor, the plant is stunted and small; and such plants seldom attain a vigorous condition, and are entirely unworthy of use as stocks for budding. 
To secure the proper mean requires grood and careful management. The soil should rather be a rich monld from an old pasture or meatow, than one recently manured; and not largely composed of leaf or swamp muck, which would tend to form a suceulent and umripe growth. When but a few thousand are needed-the best plan is to form a bed in some dry or well drained spot, in the following manner-for 10,000 seedlings, dig out a space thirty feet by fifty, two feet deep, and return only the surface soil; to this add: earth from old headlands, sods from a pasture, which have been rotted during the previous summer, with three or four loads of leaf or swamp muck, which has been one year exposed, and a similar quantity of well rotted barn-yard manure. These, with a bushel or two of lime, or what is greatly preferred, fifty pounds of super-plosphate of lime, should be thoroughly intermixed; and the seed sown in rows one foot apart. In this manner, if the season should prove to be one of drought, the bed may be watered and shaded from the sun during the hottest weather. It is important to obtain a large early growth; so that, by the first of Angust, they should be at least a foot to eighteen inches high, and quite stocky It would be much better if the seedlings could have a greater distance between them; but this peculiar management would be found quite impracticable on a large scale. Newly-cleared wood limd, when dry, and cultivated for two years, is farorable to the growth of seedlings; and in all cases, soil which has not before grown fruit trees, nust be selected, and nearly or quite as deeply tilled as the bed above described. Unless 
a grood growtl is early secured, the plants are liable to two scrious disadrantiges:

First, it they should continue late in growth, and the early frosts overtake them with suceulent and urripened wood, the frozen sap-blight will often destroy them, unless amply protected by removal and burial in the soil. And, secondly, pear seedlings are frequently attacked in the hot inid-summer inonths by a sort of lust, that appears in spots on the leares, which soon after ripen, and then the growth ceases.

The only preventives are, to secure a full growtl carly in the season, or to shade the plants during the continuance of the hot weather.

In the latter part of July, or carly part of Augnst, when the growth has become somewhat checked, and many of the leaves are ripening, the tap-roots may be cut by thrusting a long handled instrument-somewhat like a spade, but of lialf the width, thimner and quite sharp-in an oblique direction, beneath the plants, six to eight inches below the surfiace. This is practiced in England and France much earlicr, say in the midule of June, but is objectionable on accomnt of checking their growth. In the first method, the retiring sap will form new tibrous roots, which will much assist the growth in another season.

In the fall, pear seedlings must always be removed, and the first grown and best rooted selected for the nursery rows, to be budded the next summer. The eccond quality also is sometimes planted in the mursery for budling the sccond summer; but seedlings of the third quality, and sometimes of the second, are, the next spring, replanted in the bed-not beingsufliciently 
vigorous for budding. The winter is often fatal to scedlings in the bed, by heaving them out of the ground. They are therefore packed in sand in the cellar, or are buried, top and roots, in close beds, until spring, for preservation.

OBTALNING NEW SEEDLING VARIETIES.

These are the result of accidental or intentional hybridization, or of the natural tendency of the seed to change, both in the character of the fruit, and the habit of the tree. It may be assumed that, although seedlings of pears resemble the parent, yet that no two seedlings, of cultivated varieties at least, produce fruit exactly alike.

The fruit of some of the natural seedlings-that is, those not produced by complex hybridization, and found growing withont the aid of art-often reproduce their variety by their seed; or, at least, plants of almost perfect similarity. But there is erer a constant tendency in the most luscions and melting varietice to return to tlie wild state. Van Mons, of Belgium, who expended a life-time in experiments on the rariation of pear seedlings, held the theory, that "wild pear trees, in a state of nature and in their native soils, always reproduced seed without perceptible rariation; but that, as soon as the original circumstanees are altered, and the seed is planted in a new climate or soil, change commences." His theory is at this time familiar to all, and need be but briefly alluded to here. The pear selected for its seed must have trarelled, one step at least, away from the acrid crab. It is essential moreover, that it should not be of the higher 
order, as he asserted the theory, that at or near tho fixth genereatiun wi successire scedlings, the lighlest puint of excellenee is reaclicel, and a rapid declension berrins. I have nowliere seen confirmatory examples of the last portion of his dogma.

'The seeds of the variety being chosen, its fruiting was to be aceelerated by erery means, as the short life of man would scarcely sufice for the six gencrations required, when the fruiting of each was extended to the natural term of fifteen to twenty years. The seedlings were therefore subjected to root pruning: summer pinching, ringing of the bark and twisting of the limbs, until the sap retarded in its passage was tortured into forming fruit.

'Il:s seeds of the first generation, whose fruit would exlibit but slight amelionation, were sown, and the fruiting hastened in the same way, and the seeds sown successirely until the fifth and sixth generations were reached. From these he produced a great variety of glorious fiuits.

The limits designed for this book will not permit even a hint at the extensive disenssion this theory has elicited, but few ean doubt at this day, that the eausc of the rariation in all cases is hybridization through the flowers. I have never secu evidence suflieient to convince me that the continual cultivation of a eral) pear would ever alter its elaracteristies in the inclividual tree or jts grafts.

Amatenis do not, lowerer, cultivate or preserve every seedliug produced. Certain indications govern then in their selections in the secd-bed, or soon after 
transplanting, and those only receive great care and attention which are of promising appearance.

If the leares of a seedling exhibit an excess of down, or the branches are very thorny, the probabilities are against its proving of sufficient excellence to warrant its cultivation. 'To these marks of inferiority, I have added, from my own observation, a peculiar bright, deep green, not easily described, a remarkable vigor of growth, an unusual quantity of limbs, and a thick bushy foliage. 'The formation of fruit for any other' purposes than reproduction, or the mere creation of seeds, is an unnatural process-or, in other words, is produced by artificial means. None of our finest varictios of pears equal seedlings in their profinseness of foliage and shoots. In the former, the number of shoots is generally less and the growth much stonter, more stocky and straight.

When this is the appearance of the young seedling, and the leat is bright and oleaginons, instead of dull and downy, when the petiole of the leaf is long and clean, when the eolor of the wood is more inclining to purple or yellow than bright green, and when the spurs and spines which appear are blunt, instead of long, sharp, and thorn-like, we may reasonably conclude that a new variety of some excellenee will be produced.

If the fruit sets well in spring, and continnes to grow, although frosts and blasting winds hare injured other fruit, it is a sign of hardiness; and if more than three to six fruits set in a single coronal of flowers, it is a fair signal of great productireness. MLore than one season will be necessary to prove its excellence, as 
many promising fruits, in their tirst scason. lave important deferes solch as rotting at the corce grittine-:, ur arluingency. Sume excellent pears have been discarled an onteasts in their tirst fruiting, which subecquently proved to be worthy of high rank. It has heen advised not to hasten the fruiting of secdlings, ly budding on the quince or grafting on older trees, an it is supposed to change the character of the fruits too much for ielentification in future growth; but fur the=e opinions I can see 110 grood reasons. M. De Jongre, of biruscels, says:

"A lud inserted near the ground in a quince stuck, will produce fruit in the third or fourtl year; and, though the wood may acquire a different tingre, yet the furm of the fruit will remain the same, although some varieties may be larger, of richer tlavor, and in frreater abunlance. These effects are, howerer, exceptions, and are attributable to the sort of quince, of which there are several varictics, differing as widely in their influence on the Pear, as the varieties of the will pear employed for stock."

The periol of time required to prove a new variety will cexhanst the patience of most persons. Three yeats will be required to julge it the seculing promises sutliciontly to encourage its cultivation; seven years mure, with fluning and grod cultivation, to froduce fruit; fire years more, of sucessive firniting, to defintively ta-t its quality, and correctly determine its worth.

Fiftecn years of extrat care and attention are thus repuired to prove a single varicty; amel if to this we add ten years nole, lefore it can be extensively 
known and cultirated, we may see how slowly the labors of the pomologist are crowned with success, but this period may be abridged one-half by working upon the Quince.

In Mr. Hovey's splendid collection of American Seedling Pears are some of remarkable promise. Among those termed by Mr. Mover, Dana's Seedlings, are several which are admitted by such excellent judges as Mr. Louis Berchaluxs, to possess signs of rare goodness.

Many seedling collections would amply repay the labor and cost bestowed upon their cultivation; while in others, labor would be entirely thrown away upon thousands of worthless varicties, without securing one valuable sort.

\section{IIYBRIDIZING.}

It is often desirable to combine the qualities of two pears in a new variety, and this is practicable only through their flowers. When the blossoms are about to open, inclose the cluster selected with a lace bag, and when perfeetly expanded, cut away the stamens or male organs of the blossoms, and with a small colorbrush gather the pollen from the anthers of the variety with which it is designed to cross, and imprecmate the pistils left standing in the blossoms-which should again be inclosed in the lace bagn until the petals fall (Figs. 1 and 2). The seeds taken from this fruit, when ripened, shonld be planted with eare, and a finll detail of the double parentage noted. It by mo means fullows that these seeds will all produce the same firnit, for the original varieties from which they have been derived will exereise more or less influene in camsing them to vary. 
The stameus when ent away must not be ripe enough for their pollen to communicate with and

Flg. 2.
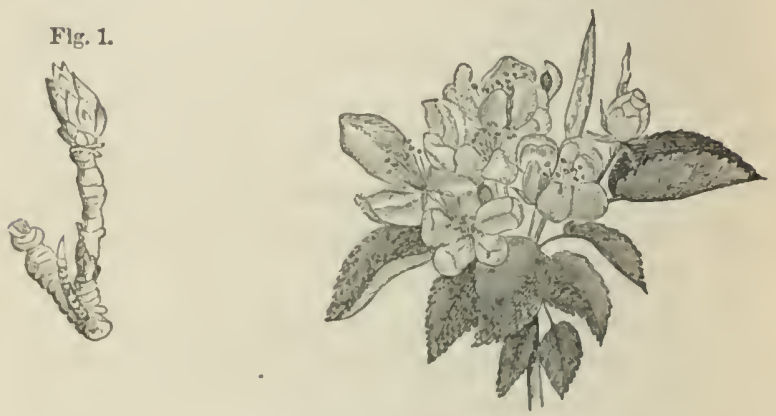

Fig. $1 \Lambda$ fruit bud near llossoming.

Flg. 2. Fepresents a curonal of flowers from a single bad.

fertilize their own pistils. The pollen used for impregnating must be ripe and powdery, and the stigma of the pistil must be damp. It was in this way that Mr. Kivisu produced his Monarch, Dummore, and other fine Pears, though the general results of this process do not seem to be remarkable.

Mr. Louis Berckmans, from whom I have freely drawn information for this work, las some 30,000 feedlings of his own propagation and of collections from Vax Moxs, Espline, Bivont, Dr. Bisckles, and other eminent pomologists, which he has selected by various marks and trikens which are eloruent to him in prophesying the merits of their finits. IIe dues not, I think, after a loug experience, pay much attention to artificial hybridization for producing new varictics.

Notwithstanding the splendil results of a systematic 
improrement of the Pear, and the noble fruits olstained by the gentlemen named, we have been indebted to accident, or rather to the voluntary contributions of Nature, for those pears which rank the highest in beauty, flavor, and general excellence. The Duchesse, found in a hedge at Angers; the Seckel, in the woods of Pennsylvania; the Virgalieu, the Bartlett, and the Louise Bonne de Jersey, whose origin is not believed to be the subject of design, all confirm this view; while we must acknowledge that there is a delicacy in the constitution of many of the pears obtained by scientific propagation, that renders them inferior to the accidental varieties.

In fact, the superior vigor and hardiness of those varieties obtained through accident, alone cnabled them to survive the neglect and difficulties under which they sprang into existence; the high-flarored, large, and truly splendid varieties produced by seientific skill and high cultivation, maintain their superiority only under the conditions in which they were nurtured. I have seen the Duchesse d'Angonlême growing on quince stock, for twelve years, in a grass plot, without attention, where it had been planted when twenty year's old, and yet prodncing large, melting frouit.

A Flemish Beauty, Beurré Bosc, or Beurré Diel would lave snecumbed under this treatment long before.

\section{LEAF-BLIGIIT OF SEEDLIXGS.}

Leaf-blight is the terror of nurserymen, and when it makes its decided appearance, his hope of suecess for the seasull is at an end. 
The discase is not necessarily fatal, but when plants in the seed-bed are attaclied by it, the cultivator will almost desire that they had perished outright ; as great numbers of them will be checked so prematurely in their growth, as to be mable to endure the rigor of the next winter.

On the first appearance of the cliscase, small brown spots are seen upon the under side of the leares of the weaker plants in the seed-bed or nursery rows, which spread quickly over the whole leaf, and in a few days, over the cutire collection of plants. Growtl stops at once, the leaves fall, and budding for that season is of course prevented. At this period all nostrums and chemicals are uscless. The finct that this disease prevals most in old murery grounds, and indeed is almost cunfined to soils long cultivated, points to the necessity of restoring to the suil its orjerinal qualities, or of planting only in new suils. The disease is doubtless of fungous cliaracter, and as its appearance on the leaf would indicate, is lighlly contagious. As remarked twenty years since, it is much more prevalcut upon the leares of secdling stocks than upon those of budded and fine viuricties. Buds set in stocks attacked with this pestilence, and which have sufficient vitality for growth, produce licalthy trees, whose leaves remain unsprotted. This lias afforded a curious sulject for speculation among pomologists.

Mr. Duwnisi: supposed this discase to be identical with the cracking and cankering of the fruit of some varietics.

Some linds of pual trees in bearing in my grounds are slightly attacked every year, but the disease makes 
no progress; the small number of leaves affected drop off, and growth commences again, though the fruit does not acquire more than half size. The best preventives are: to plant in new, deep, and rich soils; to cultivate well and obtain a good, strong growth before the first of Angust.

An article upon this subject, exhibiting evidence of close investigation, and containing suggestions of much valne, was written for The Horticulturist some years since, by Mr. H. E. Hooker, of Rochester.

\section{PROPAGATION BY LAYERS AND CUTTIYGS.}

With the Pear this is always a difficult process, and requires nice management. If the theory regarding the necessity of affinity between the stock and the graft is worthy of attention, propagation by layer's is important, for nothing can be nearer in aftinity to a variety than the variety itself. Some rarieties are much more easily propagated in this manner than others, but when the proper conditions are observed, success is attainable with all. When the leares are ripening in the early part of August, the lorrer shoots of the present year's growth should have the bark and sappy wood cut through on the lower side, to abont one third of the diameter of the shoot. Sometimes a ring of bark about an eighth of an inch wide may be removed entirely around. The shoot is then bent down into a hole (care being taken not to break it at the cut), and covered with fine soil, tightly packed. The retiring sap from the ripened leaves is arrested at the incision, and there forms rootlets. I have succeeded by this method in producing hand. 
some trees from about one half of the branches layered. When it is desirable to do this somewliat extensively, a "stool" may be formed by cutting off" the tree about a foot above the ground. The next scason there will be produced a dozen or more thrifty shoots fiom a tree two years old, which may all be lavered as above deseribed. W'hen the slioots are too high for this kind of treatment, incisions may be made in then, and balls of clay and cow-dimg mixed together put over the incisions, inclosed with matting, and ticd.

\section{QLINCE STOCKS.}

These are always propagated by layers or enttings. Any attempts at propagating by seeds would evidently be unsucecsful in producing a miform valriety fitted for budding with the P'ear.

The Angers and, latterly, the Paris varieties of the Quince, are the only ones in use for this purpose. The qualities necled for stocks are: free, rapid grrowth; a tendency to a large size so as to equal the jear trunk, and to root frecly from cutting or layers; to have a cellular and ligneons formation that will fit them to unite readily with that of the Pear. In those varieties that refuse the Pear, or on which it makes an imperfect union, we shall perecive by examining the fracture where the pear wood eleaves from the Quinee, that the alliesion has heen prodneed simply liy the irregrular and gronoved surfices of the wood of the bud and the stock, fitting into each other without any intermingling of the ligneons fibres of each, although the bark of the two species has mited to form a sheath orer the infertect union. That inter. 
mingling, and continuation of woody fibres, which takes place between a bud and its stock of the same species, does not licre exist. There is, then, only a mechanical adhesion of irregular surfaces, held together by a sheath of bark.

The apparent antipathy of some varieties of the Pear to the Quince is, doubtless, owing to the resistance made by the different texture and cellular formation of the Quince to the returning sap.

It is probable that, the cells of the Quince being smaller than those of the Pear, the inspissated sap of the latter, on its return, has become too rich in albumen to pass into them; but sufficiently accurate microscopic experiments have never been instituted to pronounce decisively upon the theory.

The tubes of all woody formations are not continuous, but successive-like the joints of bamboo: the upper ends being smaller, and fitting into spaces betwech the lower ends of the next higher series. It is commonly known that water will not pass readily through the smaller tubes, in which atcohol and ether casily. flow. From the same cause, probably, the richer juice of the Pear will not flow in the smaller tubes of the Quince; and the consequence is, that a swelling ont of the Pear at that point is formed by the repelled juice which, not finding a free passage, produces no ligneous fibres or cellular tissue in the Quince.

PIOI'AGATION OF THE QULNCE BF LATERS AND CUTTINGS.

The Quince forms a notable exception to all other fruit trees in its ability to form roots readily from any 
part of its bark. The propagation of the Angers Quinee, by layers or cuttings, is manifestly only a continuation of the original individual tree.

The cuttings steould be made in the fall or winternot later than January, sinee the buds will begin to swell in the early, warm days of winter. It is desirable that the buds should remain in a completely dormant state, so that they can make no demand upon the cutting for sap until rontlets liare pushed out, and given the entting ability to furnish it without exhanstion. It is not generally considered that roots are never added by inflnences exterior to the plant, but are the product of the plant itself. The roots of a cutting are formed ly the sap contained within itself, which, cxuling as healing lymph, is changed into roots under the peculiar conditions of air, moisture, and darkness-which process genes on eren $\dot{i}$ in winter, when the ground is not frozen. It will be seen, then, that those plants formed with large evaporating organs in the bark will not readily root, as they part too easily with their say). The close, dense bark of the Quince, and the hard rind of the outer wood of the Grape peculiarly fit them for this method of propagation; and we consequently find that, out of thousinds of cuttings planted of the Angers variety, but few fail of rooting.

The cuttings slinuld be pliuted as early in spring as possible, although their vitality is so great as to survive almost any treatment, in soils fitted for them. Juring a rather wet June, while trimming some quince stocks, preparatory to budding in August, I directed the trimmings, then in fill leat, and with some inches 
of new growth, to bs planted in the adjoining ground, which was so sandy and poor that it had been left unplanted. Eren with these disadrantages, more than half took root, and made fair plants.

The cuttings slonld be from eight inches to a foot long, and planted so as to leave an inch or two of buds above the surface of the gromnd. The soil should be rather clayey, and retentive of moisture. When it is light, it should be packed firmly around the cuttings with the foot-the closer the better. Cuttings of the Quince will usually succeed more uniformly in rather damp soils, but will not so uniformly grow thrifty when transplanted to drier grounds.

Fig. 3.

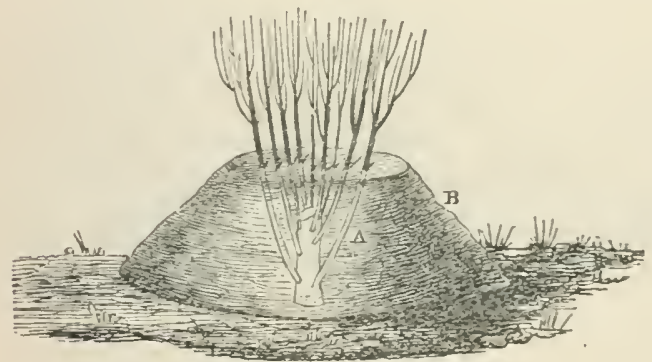

Fig. 3. Mother Stool, and usaal Plan of Layering Quince Stocks.

Quince stalks are, however, produced in much greater quantities by layers from permanent plantations of stools. These are made by planting quince roots about fonr feet apart, in very decp and richly manured soils, and entting back the growth erery year near the ground. This treatment forces up a large number of thrifty shoots, which increase in quantity as the stock grows older. 
As msually practiced, in the latter part of Angust, the earth is heaped up, and firmly packed around these clusters of shoots or stools, an in lig. 3 .

The shoots throw out roots immediately, but are not usually separated fiom the stock till the autumn of the following year. It has not been customary to commence carthing up before the second spring; but we hare fomel it of essential importance to do it earlier, so as to secure the benefit of the concentrated sap of the fall.

Fig. 4.

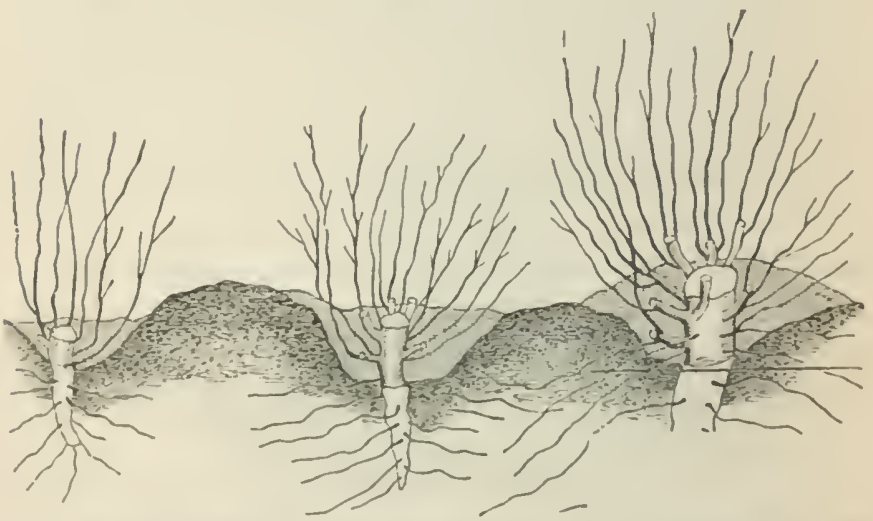

Fig. 4. Treatment of Stools in the first, second, fourth, and Afth years.

A much better plan, practiced by Mr. $\Lambda$. S. Fuller, is shown at Fig. 4. The stool is planted in a trench, which, as the former increase in size, is, at the earthing up of each suecessire erop, filled higher and higher, until, at the removal of the fifth crop, the stool is dug up, the lower pint of the root remnred, and the upper and nore vignorous portion replanted. 
PLANTING STOCKS-SOILS SUITAELE, ETC.

It is of the highest importance that only the very best rooted plants, either of quince or pear, should be planted in the nursery. M[r. Barry, than whom there is no higher authority, says, in his excellent work, "The Fruit Garden," that " one hundred good, rigorous stocks are worth five hundred poor ones;" and some of us will live to see the day when customers will pay five times more for a perfectly healthy, well-grown tree, than they will for a poor, or eren a medium one." There are a few purchasers now of the same opinion. It has been customary to crowd the nursery rows with all the plants that promised to survive, planting them only eight inches apart, and to bud them all, without discrimination, during the following summer. The consequence has not unfrequently been, a feeble growth from those buds that barely surrived; a thrifty growth in the vigorons and healthystocks; and eomplete failure in one half of the number planted.

When stocks are strongly rooted, they should be planted in the fall-provided the ground is ridged up against the rows, to prevent heaving ont in the winter. If weakly rooted, and no extra care is intended, they should be buried in light, dry soil, placing the roots thickly together in a trench, and filling it up within a few inches of the top. This should be done early, in order that the ground may be firmly settled by rains, and packed abont the roots before it is frozen. 
As early as the condition of the ground will permit, the streks so treated should be planted in nursery rows, or bedded out. In bedding ont, the weaker stocks mily be planted thickly, or only two or three inches apart, in rows, at a sufticient distance to permit plowing between. The soil should be strong and deep, and the plants receive thorough cultivation. The nursery ground should be deeply worked, and well manured a year previous to the planting of the stocks, in order that the application of fresh and powerful manures may not induce a succulent and unripe growth.

The method of preparing a plot of ground planted recently with stocks, may not be inappropriate to this scction. The soil was a sandy loam, half an acre of it being filled with bonlders, varying from the size of a paring-stone to those weighing five hundred pounds each. As these stones were reached by the plow, they were removed by laborers with spades and crowbars, and placed on the surface of the plowed land. When a furrow had been cleared of stones, the subsoil plow was drawn by a stout tean in the bottom of it, loosening the subsoil to the depth of six inches. This loosened earth was now thrown out by the common plow, and the hard soil again deepened by the subsoil plow, until the whole depth of loosened soil was from sixteen to eighteen inches. The ground was then cross-plowed, harrowed smooth, furrows drawn forr feet apart, and deepened with a spade. Thirty thonsand pear stocks were then planted one foot apart in these trenches. The whole expense for labor was as follows: 
$\$$ days' labor of team and man, in plowing and subsoiling, at

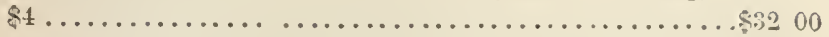

3 days' labor of 3 men to loosen and remove roeks and stones,

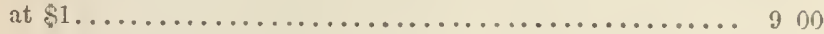

1 day's furrowing by double plowing............... 400

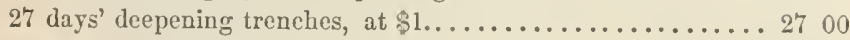
20 days' planting stoeks....................... 2000

If double the labor had been devoted to deepening the soil, it wonld have been an economic expenditure. Great care should be exercised in securing the trees in straight lines, as a tree projecting from the row is liable to injury from the plow.

The soil must be dry and rich, and the use of that common but vaguely defined term must not be mismnderstood. Properly expressed, the soil shonld be fertile without having received recent applications of strong manures.

\section{MANURES FOR NURSERY STOCKS.}

To stimulate a vigorous growth early in the season, an application of from three hundred to fire hundred pounds of guano per acre is highly approved. It shonld have been composted for a month previons to use with forty times its bulk of well pulverized swanp muck, which has been exposed to the frosts of at lenst one winter after digging. This stimulating compost, however, shonld be applied in the Fall, after growth has ceased, well distributed, and plowed in on soils otherwise in good condition. A strong and stecky growth of trees will ensue, and as this energetic and volatile manure will have exhansted its power by midsummer, the young rood will ripen fully, ard 
hecome hard and firm. A much more perfect manure for the development of young trees is formed from a mixture of guturo and superphosphate of lime. This I prepare each winter, and haye found most excellent effects from an application of six hundred to one thousand pounds per acre in the strong, healthy growth and carly fruiting of almost every tree to which it is applied.

To prepare this quantity of superphospliate, use three hmondred ponnds of burned bones, or four hmndred pounds of ground, muburned bones dissolred in one hundred and fifty pounds of strong sulphuric acid diluted with twice its bulk of water, adding one hundred :md fifty pounds of Peruvian Guano; the whole to be thoroughly intermixed. The excess of acid changes the rolatile carbonate of ammonia in the grumo to the soluble but non-rolatile sulphate, which is slower, and not corrosive or injurious in its action on plants. The resnlting mixture being in a semifluid state, some absorbing material will be needed to act as a divisor. Peat or swamp muck, nearly dry, will be the best sulstance, and may be used in large quantities, being itself composed of the ligneons and carbonaceons proincts of the growth of wool. This compost may he spread broad-cast, or strewn in furrows plowed near the rows. The necessity of furnishing the dements found in this mamme mily be secn at once in the chemical analyses of the Pear, its bark and woorl.

()n the firm of Prof. Mares, several varieties of pears, which with us have not hitherto mantained their European reputation, have been produced, of 
great excellence, by application of the phosphates. The fruits were pronomeed by Louss Berecisins, Col. WILDER, and others, the finest of their kind erer grown in this comntry.

A study of the following analysis will show the necessity of using potash in addition to the elements found in the superphosphate and guano, which may be supplied to the soil in the form of crude potash, green sand marl, or woodashes. Neither ashes nor potash should be mixed directly with guano or stable manures, or so placed in the soil as to come immediately in contact with each other.

AYALYSIS OF THE ASHES OF THE PEAR.

One hundred pounds of fruit yicld nearly half a pound of ashes, the wood and bark much more.

\begin{tabular}{|c|c|c|c|}
\hline ASIES OF & IIEART WOOD. & BARK. & FREIT. \\
\hline Potash.. . & $27 \cdot 00$ & $6 \cdot 20$ & $54 \cdot 69$ \\
\hline Soda. & - & - & $8 \cdot 59$ \\
\hline Lime....... & $23 \cdot 14$ & $33 \cdot 36$ & $7 \cdot 98$ \\
\hline Magnesia.... & $3 \cdot 00$ & $9 \cdot 40$ & $5 \cdot 22$ \\
\hline Sulphuric Acid... & 0.45 & $1 \cdot 80$ & $5 \cdot 69$ \\
\hline Silicic Acid. . & $0 \cdot 30$ & 0.40 & $1 \cdot 49$ \\
\hline P'hosphoric Acid........... & $10 \cdot 40$ & $3 \cdot 50$ & $14 \cdot 2 \mathrm{~S}$ \\
\hline Phosphate of Iron........... & $0 \cdot 50$ & - & $2 \cdot 00$ \\
\hline
\end{tabular}

PREl'ARATION OF STOCKS FOR PLANTLYG.

The small cost of stocks has induced a carcless method of planting, and a more incxcusable neglect in preparing them for it. Quince stocks are usually taken from the mother plant or stool by a quick jerk, which leaves a large ragged end ; as it strips otï the bark and wood from the stool, for a space at least twice the diameter of the stock. At the season when 
this is performed, no healing lymph exndes, and of conrse, no rootlets are prorlueed ; besides, the rugrged wound does not encourage their furmation. A raw, unhealed end always remains; and of some thousands of pear trees upon quince roots, which I hare remosed, I liave never seen fibres put forth, where such a wound has been made. The rough corrugated ends will show the marks of the rupture made by their violent removal from the parent stock.

The injured roots of stockis should be smoothly cut, and the jagged portions cleanly pruned areay, leaving a surface, from which fiesh rootlets will realily spring.

In the violent removal of the stock, the bark is stripped from nearly all of the fibrous roots; and if they are not remored, a large mass of decaying organism must be thrown off', before a healthy vitality can commence.

When the fibres are thick and matted, they shonld be cut back to an inch in length, or they will be pressed together in the soil, and deeny. Two rootlets or fibres nerer come in contact when growing, and this conclition should be accurately imitated in planting.

Pear secdlings, which lave not been root-pruned in the seed-bed, have long tap-roots, which should be shortened to six or eight inches. It has been recomincuded to lay out the tap-root in a horizontal direction; but the distorted position obstruets the free flow of salp; and the rout receiving nutriment from only one direction, the tree will he distorted by growing mostly on the sume side.

'The tops of stallis are frequently allowed to remain; 
but they should be well pruned, in order to induce a new and large-leafed growth to prepare sap that on its return will strengthen and mite the bud to tho stock. When all of the top is allowed to remain, the leares will be small, and but little new wool formed,

Fig. 5.

Fig. 6.

Fig ?.

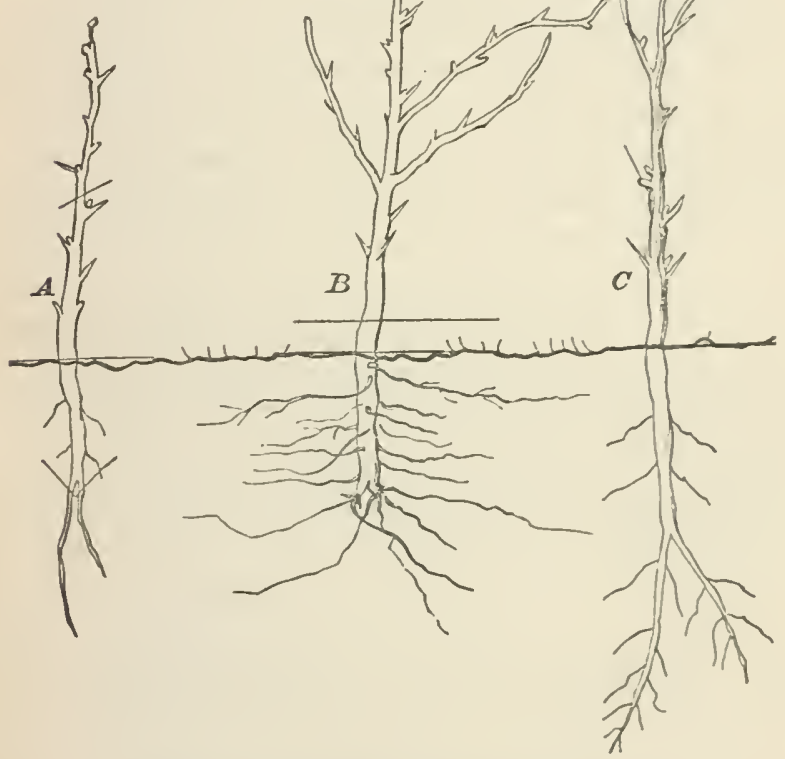

Fig. 5. A secdling of one year's growth.

Fig. 6. The same at two years, after root pruning.

Fig. 7. The same at two years, with pruning.

while close pruning wonki induce large and vigorous leaves capable of preparing great quantities of well aerated sap.

The contrast between Figs. 5 and 6 is not too 
strongly pictured, to represent the real advantages derived from root and top pruning. The pruning of the top should always be done before planting, as the roots do not obtain sufficient liold of the soil to prerent their being disturbed and pulled out by the knife.

INFLUEXCE OF TIL GRAFT UPON LONGEVITY.

The increase of the number of trees of a given variety lias for some year's been considered as a simple extension of the original tree of that variety. Grafts or buds taken from any variety of the Pear, when inserted into a pear stock, will entirely change its characteristics, and enforce the production of their own rariety of fruit. Having this power, it is not too much to believe, that they liave that also of carrying with them whatever defect of constitution, or feelleness of vitality, may infect the plant, and that trees produced from them would be feeble or strong, short or long-lived, in proportion to the possession or want of these qualities in the original.

That the defeets of a tree must limit the powers of all its descendants, is a well known physiologrical fact. But the different trees of a vilriety are not descendants from an original of that varicty, but only parts of it; and starting from this basis, some pomologists have asserted, that as all the trees of any variety are but branches from the original, and not the product of fecundated seerl, they must be limited in their existance by the life of the origrinat.

In this theory, however, suflicient allowance is not made for the increase of vitality, by alliance with 
a vigorous stock, which is the prodnet of a seed; and hence possesses the elements of independent life, and the power of infusing much of its o $\mathrm{mm}$ principle of longevity into the engrafted seions or bnds.

It would be more nearly correct to say, that the duration of a variety is limited more or less by that of its original, and that any inherent disease in it will be continued, in all its buds and grafts, although the superior vitality of the stock may mitigate its virulence, or protract its dormant period.

Certainly, a settled conviction is obtaining among pomologists, that some of our finest varieties, that hare been in existence for but the short time of fifty to seventy years, have nearly reached the culminationas they can now only be produced, in any degree of excellence, by the ntmost care.

The White Doyenné, the Chaumontel, and others, are notable instances of the justice of this conviction. Some localities still produce fruit of these rarieties of great beanty and excellence ; but eren there, the invisible hand of disease has stealthily tonched their fruits, and the plague-spot is appearing upon their golden cheeks.

The influence of the stock mpon grafts is very marked. The fruits of early summer varieties are retarded in their ripening when grafted upon winter varieties; and pears that should keep until Easter, will ripen in December, it the tree which prodneed them wals grafted upon a summer variety.

Similarity in growth and color of wood, and in style and color of leaf, between stock and graft, is important 
in attaining perfection, but impracticable on a large sealc.

\section{MLTIODS OF GIEAFTING.}

Scions for arafting sliould be of one or two years' growtl. that liare not yet produced fruit-buds. The Elowts selected should be firm-wooded and stocky, with buds close together, as a strong, healthy growth is characterized by these marks.

Gibatts talien from the upright shoots near the top of the tree are apt to make a vigorous and upright growth, luut are more tardy in bearing. Taken from the lower part of the tree, they produce a more widelyspread form, and fruit earlier.

The trees from which the grafts or buds are taken should be healtlyy, and have produced a rigorous growth during the previons season, but such as have at any time exhibited symptoms of frozen sap-blight should especially be avoided.

Tarieties which sueceed but indifferently on quince stocki, ought not to be propagated by scions from trees grown on quince. Indeed, it is a mooted question whether grafts should be taken at all from such a Eource; lut I see no reason for going to this extreme.

The part of the graft used with the most success, is that at the junction of the spring and midsummer growtl, which is marked by a somewhat fainter annular swelling than that at the commenecment of the spring growtl.

The theory of grafting is, that the newer tissues of woody growth unite, when brought into contact, if their falp-lessels are not inlurated ly agre. The termini of the cellulan tubes are capable of exuding 
the albuminous deposit of the sap, which unites the graft to the new woorl of the stock.

It is not unfrequent that thrifty grafts of two or three years' growth are blown out of the cleft in the stock; and it will always be found on examination that only the bark and extreme rind of sap-rrood hare united, while on the remaining surfaees, woody matter has been deposited without adhesion.

When grafts are proeured from a distance, or it is necessary to keep them some time before use, they should be cut in winter, or early spring, before the buds liare
packed awa
ately damp
lowed to
exposed to eause the supply can not be maintained.

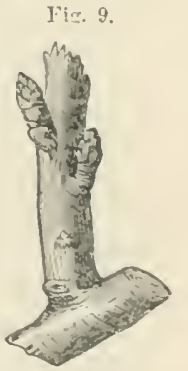

Grafting of the pear is usually performed only on large-sized stocks or upon bearing trees, exeept in

* lig. 8 represents a branch, exhibitiug wood-buds, in tho best condition for a graft.

+ Fim. 9 represents a branch with fruit-buds, unfii for $₫$ grafh 
nursery stocks, where buds set the previons season liave failed. On the smaller stocks, of one to four years of age, budding is by far the preferable method of propagation.
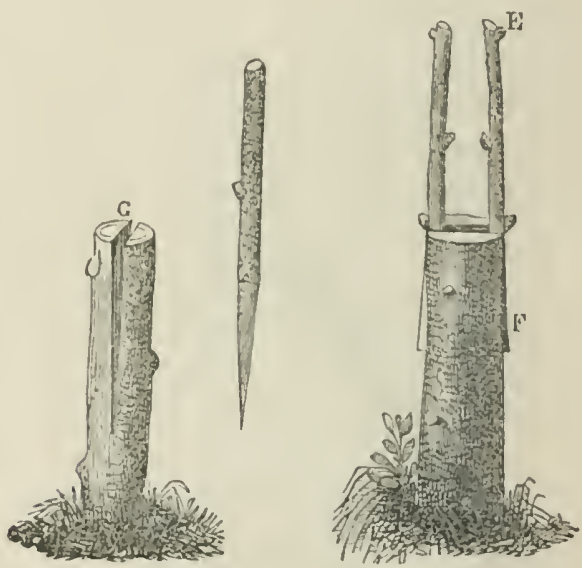

Fig. 10. Cleft-grafting with single graft.

Fig. 11. Cleft-grafting with double grafts.

When the trees are large, only the younger and thriftier limbs should be grafted; but when all the branches are old, and covered with rongh bark, a sufficient number of them should be shortened, in order to induçe new growtls, on which the grafting may be performed, as shown in Figs. 11 or 13.

Thousands of pear trees, almost gigantic in their size, in all parts of our country, now bearing only the most acrid fruit, could each be made in a few 
year's to prociuce almost a wagon-load of the finest pears.

When it is desirable to gratt small stocks, it should be done by the process known as whip-grafting, as illustrated by Fig. 12. In Fig. 13, the cleft, which is a simple split, is exhibited open, as it would bo

Fig. 12.

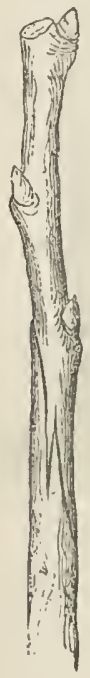

Fig. 13.

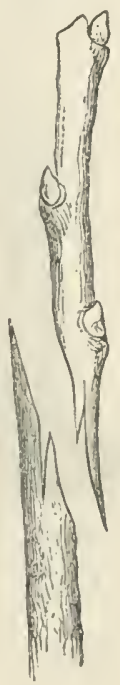

atter the insertion of the parts. Cleft-grafting is usually performed on stocks of more than half an inch in thickness-as shown by Figs. 10 and 11.

All of these operations can be performed during a month or six weeks subsequent to the first swelling of the biid, or from the fiftecnth of March to the first of May. The exposed surfices should be well covered 
witl grafting-wax. Crown-grafting, as shown in Figs. 14,15 and 16 , is performed by cutting the graft only

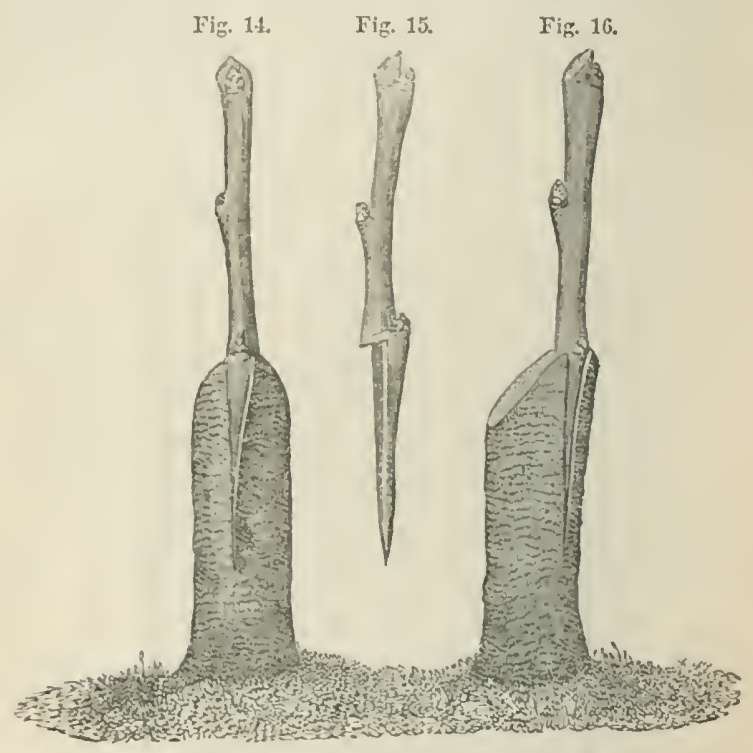

Figures 14, 15, and 16. Graft and Cromn-grafting.

upon one side, learing a square shoulder, and pressing it down between the bark and the wood. More than one graft may be set in a large stock. The cleft in the stock, and the exposed surfaces, where the latter has been cut, should be well protected by graftingwax. This is commonly made to be used when cold by melting three pounds of resin, to which three pounds of hees'wax and two pounds of tallow are added. After stirring together, so as to incorporato the ingredients, the whole may be poured inte a tub of cold water, and worked with the hands. 
While pear trees may be propagated with a measure of success by other methods, it is by budding only that they can be raised in large numbers with economy and entire success. The constitution of the Pear especially fits it for this process.

The firm, tough bark of the stock, and the abundant coating of mucus which lines the interior of both the bud and the stock, enable the operator to effect a clean separation of the bark from the wood, without injury to the texture of either. The ripe mucus sap secures an almost immediate union of the parts. In growing the Pear upon the Quince; the superiority of this method of propagation is still more marked. Mr. Rivers says: " of twenty grafts set in quince-stocks, it

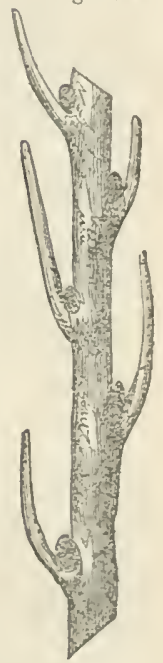
not unfrequently happens that nineteen will live, but nearly as often that nineteen will dic." In my own experience with trees grafted upon quince-stock, they have proved to separate more easily at the juuction than trees propagated by budding. It is only the bark, and the more recent formations of wood, which unite when brought into contact; and this union is effected by layers of rood, deposited around tho junction, in the glutinous condition of lymph.

* Fig. 17, represents a stick of buds, with leaf-stalks for handling. 
These fitcts slow that a bud, composed, as it is, only of bark, and of alburnum or lialf-formed wood, prescnting a great surface of fresh material, will form a more rapid and complete mion with the stock than an ordinary griaft. In this country, where thoroughuess in the pertormance of work is often sacrificed to rapidity, it is the general custom to leare a portion of wood witlin the section of bark comnected with the bud, as seen in Fig. 1S. This arises,

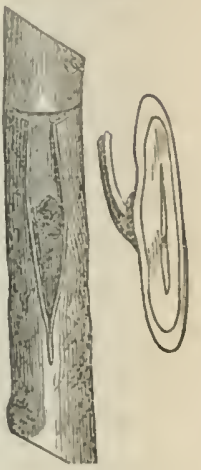
in part, from the diflieulty of separating the wood from the bark withont disturbing the chit bencails the bud, the retaining of which is essential to suecess in budding. This small kernel of congulated albumen, as shown in Fig. 19, is the stored-np material on which the bud feeds when quickened into life, and which comnects its vitality with the wood beneath. To remove this deposit would insure the death of the bud, or at least allow but a f'ecble growth. Liy carelessly taking ont the wood from the bud, the chit wonld adhere to it, and thus be displaced-as in Fì. 20.

If the wool be left in the bark, as in Fig. 1s, the edges of the lauk of the bud would mite with the stuck-the vital circulation being thus estab)lished. But this piece of wood is a fureign substance, and the mion will be much more perfect when the whole interior surfice of the batrk of the loud is allowed to come in contact with the wood of the stock. From

- Fig. 18 shows a cut bud wilh tho wool remaiuing, and figure of bud insorted. 
my own experience, I have learned to estimate trees produced by this metlod much more lighly than those budded in the more common manner. They form a stronger union, and resist the pressure of heary winds without cleaving apart at the junction of bud and stock. Several methods have been alopted for the rapid and efficient removal of the wood from buds, but none of them admit the possibility of the inseltion by one man of 1200 to 2000 buds in a single day, as is claimed by some persons.

An admirable plan is shown at Fig. 21. The process, consists in thrusting the tough, but not harsh

Fig. 19.

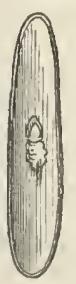

Fig. 20.

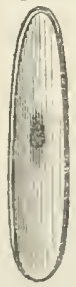

lig. 21.

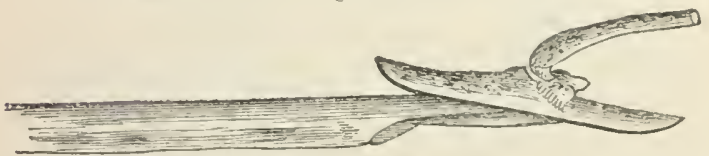

Fig. 19. A bud with the eye preserved.

Fig. 20. $A$ bud with the eye removed.

Fig. 21. Quill as usod in separating wood from the bod.

edge, of a quill, under the upturned edge of wood, and pressing it firmly and gently forward; the clit is cut smoothly from the rood, and remains in its proper place, attached to the bud.

The thickened mucous sap which lines the bark, and covers the wood, when elosely cxamined, will 
exhibit a cellular structure of albuminous materials attached to the chit, ready to extend themselves into the shoot, which the dormant bud will ultimately form.

Fig. 22.

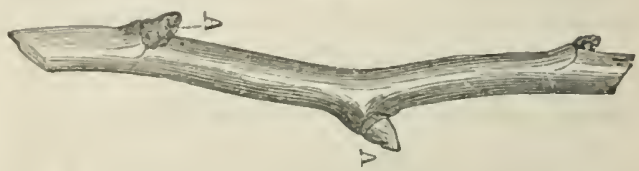

Fig. 22. Stick with bud at A, too high-shouldered for sctting.

The operation of fitting the bud to the stock, after cach is eut, should be performed almost instantaneonsly. This is equally necessary to prevent the drying, and the chemical change of the exposed sap, which alnost immediately oxidizes, and tums brownlike the flesh and juice of an apple, when eut and exposed to the air.

Fig. 23.

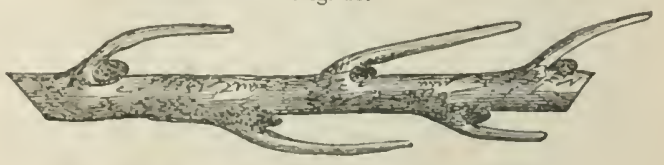

Fig. 23. Stick of bnds, elected properly.

For butding, select young, vigorous shoots, of the present year's growth, with well-ripened buds, as shown at Fig. 23. Cut off the leares, allowing the foot-stalks to remain attached to the bud, serving as a handle when the bud is fitted into its place in the stock. Reject the upper and unripe buds, selecting only the plump, well-ripened ones. Hold the larger end towads your body, inserting the knife-blade as far above the bud as you intend to leare the bark below it, and separate the bud, with a rather deep 
cut into the wood, as shown at Fig. 24. Hold the removed bud by the foot-stalk, and with the quill take away the woody portion. If you choose to leave

Fig, 24.

Fig. 25.

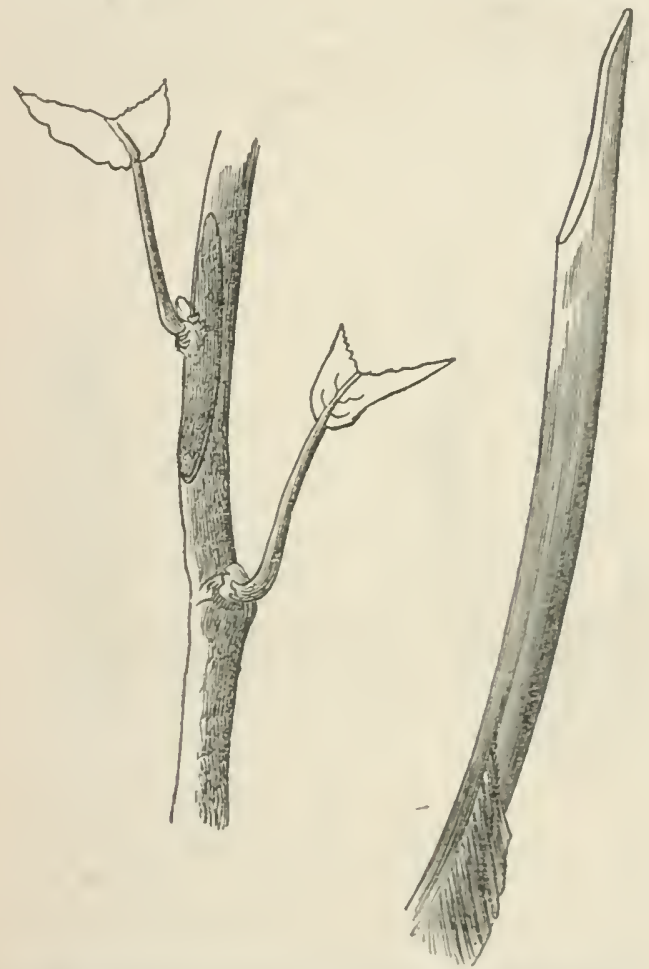

Fig. 24. The proper cut to be made in separating the bud.

Fig. 25. Quill prepared for separating bud from the rood.

the wood, pare it down as thin as possible. If you are not expert in the manipulation, shicld the bud from the air by placing it in the mouth, or in a ressel of water. Make the incision quickly in the bark of 
the stnck, as in Fig. 26 ; raise it from the wood, and push in the bud, by the leaf-stalk. You may now cut off the bark abore the bud, so that it will exactly fit the cross incision, and tie the whole gently, but firmly, with strips of bass matting, as at Fig. 27. The ties should be loosened in two or three weeks after the budding is finished, and entirely removed before winter sets in.

Fig. 26.

Fig. 27.
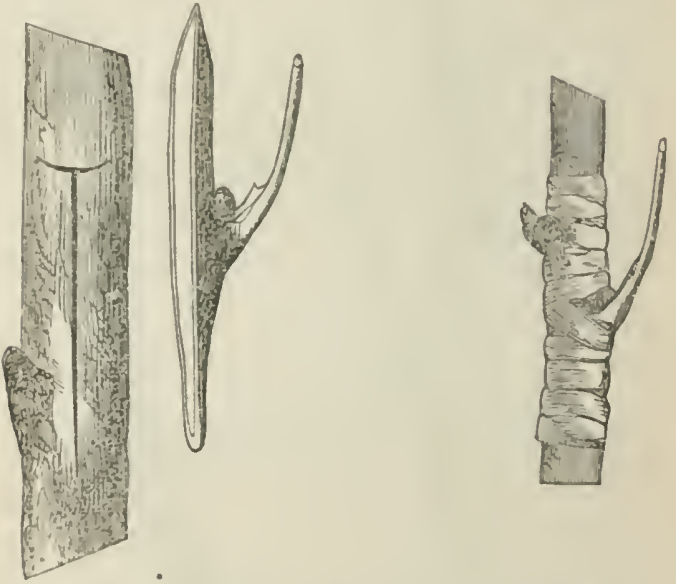

Fig. 26. luad with wool remored, and stock cut for insertion.

rig. 2\%. liud inserterl anil tied.

Budding is occasionally perforned in spring, but not to any extent in commercial nurseries; nor is it universally suceessful, although a convenient process, when buds which were inserted the previous summer have failed.

The period for budding the Pear extends from the midalle of July to the midale of Suptember-the pre. 
cise time aepending on various local cireumstances which affect the grrowth of the tree. The season may be a late or early one, or a poor soil may have retarded, or a rich one stimulated the growth, so as materially to affect the period for budding. Dry summers and late spring planting of stocks will also retard the operation. The observation of the following points will assist in selecting the proper time for budding. The first or spring growth of leares should be fully ripened, and the midsummer growth nearly completed. At this time, an abundance of ripened or richly albuminous sap is thrown between the bark and wood, and when both the stock and the bud are in this condition, mion is readily effected by the hardening of this sap into tissue.

The stock should be cut three or four inches above the bud, as shown at Figr. 2S, soon after the leares start, although with very strong and well rooted plants, care must be observed not to deprive the plant of all its top, until the bud has put forth a shoot some inches in length. As soon as the latter has grown to nearly a foot in height, it should, if inclining from the perpendicular, be staked and tied. Occasionally, the stump of the stock will afford suflicient stay for the support of the shoot withont the use of a stake.

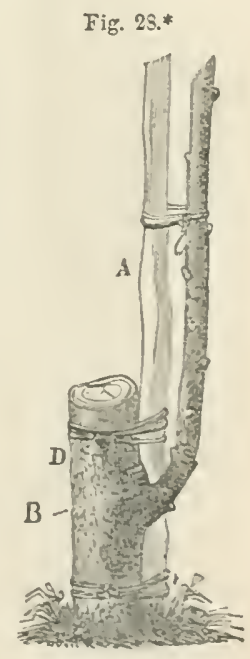

* Nig. as represents the treatuent of tho budded plant during the dirst sumares 


\section{PART IH. - SELEOTING, PLANTING, AND CULTIV ATION.}

SELECTING PEAR TREES FROM THE NURSERY.

Everx fruit grower should either select his trees for himself, or obtain the services of a competent person. There are so many circumstances governing the success of nursery trees, so great a difference in their growth, and their roots, as well as in the manner in which they are taken from the ground, that the most careful attention is necessary to avoid the numerous chances of failure. The soil on which the nursery trees have grown is a subject of some consequence. It should be one well snited to the permanent growth and fruiting of the trees. Some nurserymen, in order to meet the quickened demand for large and handsome pear trees, stimulate their growth by profuse applications of manure. This practice will produce a sueculent mripened growth, and the trees, when planted in an inferior soil, are either killed by winterblight, or languish for several years.

An instance is narrated of a nursery which was advertised as containing immense numbers of pear trees, which was eaid to have been manured at the rate of two lundred double wagon loads per acre. 
One large nursery of pear trees, which came under my observation, was located upon the bed of a drained mill-pond, the water still standing at two or three feet below the surface in the ditches, which were dug at such distances apart, that the water rose to the surface between them. On this allurial soil, an enormous growth was obtained, but at the expense of the healthfulness of the trees. Of some fifteen hundred pear trees obtained by the author from this ground, nearly half perished by blight during the first year. Other nurseries may be seen located on imperfectly drained alluvial soils. Pear trees grown on such grounds are always deficient in fibrous roots, and consequently less able to bear transplanting.

Disappointment, also, often attends the selection of trees transplanted from poor and neglected soils, particularly those that are light and sandy. The plants acquire a stinted habit of growth, from which they seldom or never thoroughly recover.

The purchaser should observe if lice or other parasitic insects have made a lodgment upon the trees, and guard against domesticating a pest which it will require years to exterminate. Trees infested by them in the nursery, are generally stmuted, and their growth, for a longer or shorter time, retarded.

In selecting plants for pyramid trees, choose those that have branches or branch-spurs within a foot of the ground, and fairly distributed along the stem. It will be impossible to find trees in any considerable munber with the branches perfectly arranged, still those only should be selected for this purpose which approach the standard as nearly as possible. 
The stem or trunk of a healthy mursery tree will usually be twice the dianeter near the ground that it will be three feet above, and decrease with a regular taper towards the top. Stems that are of the same size at the collar, and three, or as sometimes happens, eren five fect above it, hawe been forced up in their mrewth by erowding in the rows, or by injudicions juning. The lieight of trees shonld be a secondary olject compared to other qualities. The bark should be clean, of a lustrous appearance, and firee from ungainly sears from wounds made by the pruning linite.

Nurserymen are often foreed, by the popular prefercnce fur tall trees, to prune them contrary to their judgment, so as to induce growth in that form: the lower part of the tree, deprived of its portion of the foliage, remains mudeveloped, while the top is increasing at its expense.

The purchaser should ascertain, if possible, how old the trees are, and how long they hare stood in the mursery rows without being lifted, or root-prmed; for a tree of any lind, and especially a pear tree, will not be well provided with tibrons roots within the circle dug in taking it up, after standing for three or four ycars, without root-pruning or transplanting; nor will a pear tree form these fibrous roots, on which depend its vitality and firuitfulness, unless the stock, on which it was budded, has been properly treated for their formation. It is the practice in some of the French murseries to cut off the tap-root of pear seedlinger when they are three or four inches hight to cause the growth of fibrous roots-just as we pinch off the 
terminal bud of the yearling shoot, to produce lateral branches. When taken from the seed-bed, the plants, instead of the single tap-root, ten or twelve inches long, will have three or four roots from four to eight inclies in length. These roots are shortened, and the plants set in the nursery rows, when a mass of fibrous roots will be produced. If the trees remain in the nursery for more than two years, the roots are again shortened.

A healthy pear tree, three or four years old, twice transplanted, is worth fifty per cent more than one of the same age, though of much greater size, remaining where it was budded. When the trees are lifted in the nursery, observe whether the roots are fibrous, and numerous; and if they are not, but consist of long, naked roots, or of two or three straight forks, their chances of successful transplanting are rery small.

\section{CACSES OF TIIE FAILUTE OF NURSERY TREES.}

The varions causes of the failure of trees obtained from nurseries would require almost a lifetime to investigate, and a volume for their enumeration. A few that have fillen under our observation will be simply nariated, without discussion.

1. The too great crowding of the trees in the mursery rows, by which a fair supply of roots cammot be obtained.

2. The trees are dug with too little care, and sent away with mangled and shortened roots.

3. Purchasers are not always sufticiently liberal to be willing to pay for the best trees, or for matting and packing them. 
4. The trees may be too old, or hare stood too long without transplanting.

5. Batd pruning.

6. The practice of grafting on old stocks, to which the new wood las not the power of assimilating.

7. The practice of gathering seeds for stocks from any and erery source, from diseased firuit, and from the fruit of discased trees; while the seed of small and wild pears only are fit for the purpose.

S. The custom of using suclier's from old pear-tree roots, which seldom attain a fair size or thrifty grrowth.

9. The cmployment of the common and the Portugal Quinces for stock, instead of the large and rapidly growing Angers rariety.

\section{PROPER AGE FOR PLANTLNG.}

This will depend much on the growth and treatment in the nursery. I am decidedly of the opinion, that when pear trees are to be left to struggle with the ordinary difticulties in an orchard, even when they are to liave skillful attention and watchitul care, they should not be planted less than four years old. This requirement, howerer, is not witlont exceptions. For instance: when they are to be planted not fartlier apatrt than twelve or filteen feet, and have some of the advantanges of good mursery treatment-in this case, even yearlings may be planted at onee in the fruit ground; also, when they are to be planted at greater distances, and the grower will not begrudge the bestownent of so larege a piece of ground to tho 
cultivation of such small trees. The disadrantages of planting small trees are, that they are liable to be injured by the plow, and browsed by cattle, accidentally or intentionally admitted, or by the animals used in tillage. Perhaps the most formidable objection is, that the owner will regret what he deems the waste of a valuable piece of ground for so many years; and against his own judgment sow or plant an injurious crop among his trees.

There is, however, a much better method of treating young trees, than to subject them to the chance of all these evils. If they have not been transplanted or root-pruned, select those of two or three years' growth, and prepare a piece of ground for the home mursery. For this a rich, deep, dry soil should be spaded and thoroughly pulverized, to the depth of two feet. In it plant the trees in rows four feet distant, and three feet apart in the rows. Two hundred trees would here occupy a space fifty feet square. The roots having been carefully examined, and, as before mentioned, the laterals pruned to six or eight inches, are spread ont horizontally, and gently covered with earth. It will be seen that the labor of pinching, pruning, and cultivating, will be much less on so small a spot, than when the cultirator is obliged to trarel over the three or four acres, upon which they are ultimately to be planted.

If at the end of two years it is still desirable to allow them to remain, a sharp pade should be thrust down around them, at a distance of fifteen or eighteen inches, in order to cut the long stragggling roots, and thus induee the formation of roots nearer home. This 
will fit them for transplanting at an adranced stago of growth. In this cal-e, it' at the end of two or thee Years they are remured at the proper season, and with care, they will sufier scarecly any check. By pursuing this plan they receive better care, grow fiaster, and are not liable to lannge; and as only good trees will in this case be set in the fruit gromuds, none of those unseemly brealis in the rows, caused by the death or injury of a tree, need occur.

Where, lowever, older trees, at least once trams planted, ean not be obtained, and it is desirable to set ont the orchard at once, stont two-year-old trees are decidedly preferable. Such trees have not stuod sufliciently long to send their roots beyond a limit, whence they can be remored; and with eareful digrging, removal, and plantingr, the pureliaser need not fear a loss of more than two per cent. Quincerooted trees can be remored at any agre. When orer ten years olil, and twelve to fifteen fect high, they can be transplanted with as mucl safety as pear trees, grown ou pear sucts, at two years of age. Captain Ricliardson, of brokulyn, who sailed the "Dnchess d"Orleans," a Havre packet, for many years, was induced by al French grentleman at that port to bring home in his vessel some large pear trees, grown on quince roots.

The:c trees were nearly twenty fect higrh, with al main stem six or eight inches thick at the base, hranched cluse to the gromend, and each as perfectly comical as a Norway Spruce. They had been in bearing in linance for nearly twenty ycars; and are now, after thinteen years of rrowth in at new sril, beautiful objects in slape and foliage; and what is more, pro- 
duce every year large crops of splendid fruit. Of the six thus bronght three thousand miles, tire are still living.

Persons planting large pear trees will, withont doubt, obtain many advantages which they could not expect from smaller ones; yet these are entirely conditional upon the treatment the trees have previonsly received.

To repeat, pear trees upon quince roots, of ten or' twelve year's of age, may be removed with almost perfect certainty of success. But to insure safety with trees upon pear stocks, whose branches have not been shortened-in, they should be either pyramids or half standards, so that fibrous roots will hare formed near the stem; or they must hare been root-primed, or transplanted in the nursery. But in the case of stand. ards, whose growth has been unchecked, roots as long and numerous as the branches will hare formed-which, of course cannot be retained in transplanting. Such trees can only be safely transplanted when reotpruned the previous year, by digging a trench around each, and cutting off all the roots which extend into the trench. These trenehes should be filled with good soil, to induee the formation of fibrous roots.

After much experience in planting large trees, I an convinced that the pear is the only species of fruittree eapable of being readily transplanted at a large size; and that when the foregoing directions are complied with, the pear culturist may obtain an adramee in the fruiting of his orehard of tive or six years.

Instances of success in the plauting and fruiting of large trees are numerous. In the spring of 1856 , 
Mrr. L. Prek, of New IIaren, removed to his garden a Flemish Deanty, welve years old, which, in the fill of $18.5 \%$, bore a bushel of pears that averaged larger than Duchesse d'Angunleme, grown on the same grounds.

$\Lambda$ large number of trees of equal size, planted at the same time, proved nearly as successful. Mrr. Win. Howe, of North Salem, Westchester Co., planted a few years since, some large trees from the pear grom of Mr. Simuel Parsons, mentioned by Mr. Bary in lis "Fruit Garden," and in two years oltained from it then the finest Vicar and Easter Beurré Pears cxhibited at the Fair of the $A$ merican Institute for that year.

\section{SEASON FOI REIOVING AND PLANTING TREES.}

Onr comntry possesses such a varied soil and climate that no general rule can be giren for the time of planting; indeed, the exact period must differ with almost every season. The remoral of trees should take place while the rital powers are dormant, or nearly so. This is indicated by the ripening, and ultimately by the fall of the leat, which occurs, in the latitude of New York City, from the middle of September until the first of November. From the period at whicl the leaves ripen until they form again in April or May, trees may be remored with safety whenever the state of the weather will permit, and the soil is sufticiently free from frost for their reception. Large numbers of trees are removed from nurseries, and planted with success, immediately after the leaves have leen killed hy early frust-such as remain on the tree having heen stripped oft.

The fibrous-rooted quince and root-pruned pear 
trees are liable to be thrown out by the freezings and thawings of winter, if they are not planted sufliciently early to allow the settling of the soil about the roots before the ground freczes. When planted in autumn the trees should receive a heap of carth about their trunk and over the roots. If the trees to be planted ean be obtained at a period in the fall when one may reasonably expect fine weather and warm rains to assist in settling the earth, before it is frozen, the hurry and nneertainty of a late spring should be avoided by autumn planting. The season best adapted to the transplanting of the Pear is, that short period before the commencement of severe frosts when the leaves and wood are perfectly ripened, and the former easily parts from the tree. At this period, the great flow of sap to the leares has eeased, and every cut and bruised rootlet will receive a corering of healing tissue, through which, within a few days, rootlets will push ont.

During the fall and spring, when the ground is not frozen, these radicles are increasing, and are ready to commence their office when the first leaves begin to put forth. Not only do the rounded roots send forth fibres, but twigs of the pear-wood which have been properly layered in late summer will be well previded with spongioles. Trees remored in early autumn, with care, will scarcely show any check, and will often fruit as well the first season after plinting ats if they had not been disturbed.

Trees received firom France, which have been dug when wood and leaf were fully ripened, will, on their arrival here, exhibit on their pruned roots, and eren 
on theil broken branclies, a thick coating of newlyfurned tissue, and wten many joutlets, an inch w more in lenerth. The most skillul English nurserynen and fruit cultivators sclect early antumm for the removal of their trees.

It trees arrive in early spring, one should not hasten the planting so much as to be obliged to perform the work indifierently, by planting in sliallow holes er poorly prepared soil. Lay the trees in by the heels, covering the roots deeply with loose, fine earth, and then plant them at leisure, remoring them fiom the trench un faster than they ale required. By occasionally moving the trees heeled-in, the period of plauting may be delayed until the midrlle of May. It must not be forgotten, that the leaves should be fully ripe, and all growtl completed, else the evaporation of sap through the still actire leares would go ou too rapidly for the supply afforded by the maimed roots.

\section{IROTS OF TIE PEAR.}

As the Pear tree advances in age, the difficulty of successul removal increases. The reason is not always understoon by those who secm to consider the roots as chicfly valuable for sustaining the tree in an uprighlt position, and obtain with the tree the least number that will perform this office. Almost all persons believe that it, by diut of extra labor, they have secured a few longr, naked canes of roots, that they have performel their work almiralily; althongh by carcless digrringer or pulling the routs through the soil, they may have destroyed all the har-like filmes which alone grive value to the main roots. The nowrislument 
of trees is receired from the soil, through the agrency of the hair-like rootlets which spread through it from the termini of the larger root. No matter how many large roots may be attached to the lifted tree, its removal will only be well performed when you have secured a large quantity of fibrous roots.

As the tree increases in size, the roots near the body exhaust the soil of nutriment, and the absorbents, or fibrous spongioles, become hardened by age, and incapable of action. New fibres push ont from the termini of the rootlets into the newer and richer soil, and the office of those in the exhansted ground is at an end. Nature supports no useless members in her economy, and those radicles which have performed their office, and become ineapable of aftording further aid, are cast off'.

Thus, year after year, as the roots extend and throw off their fibres, the new spongioles supplied are found farther and farther from the trunk, and more and moro labor must be expended in the digging, to obtain a sufficient number of them to sustain the tree in its new position.

No one need expect a tree to flomrish, or indeed do more than barely survive transplanting, who is careless about the kind of roots with which his trees are supplied.

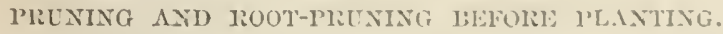

Althongh the Pear tree will endure more severe pruning, and yield more readily to moditications of its form, thm other finit-trees, yet this fucility of management may cause us to lose sight of the fact, that the 
restraint of its irregular growth can be better performed in its sucenlent condition by summer pinching. Bit as the form of nursery trees is usullly very imperfect, and will require serere pruning to recluce it to regularity, we shonld perform this labor in

Fig. 29.

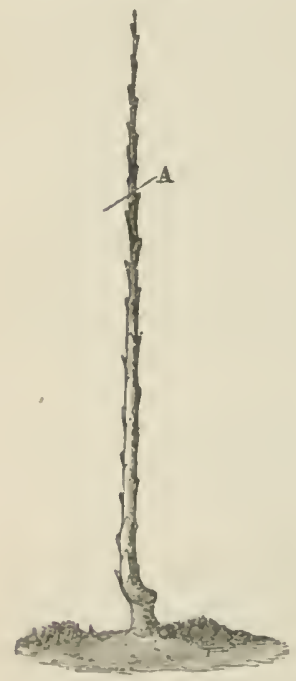

Fig. 80.

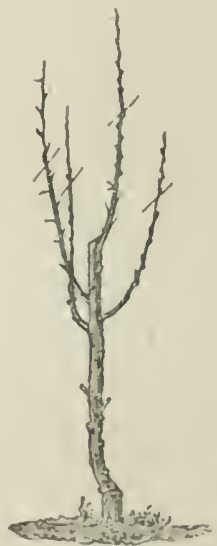

Flg. 81 .

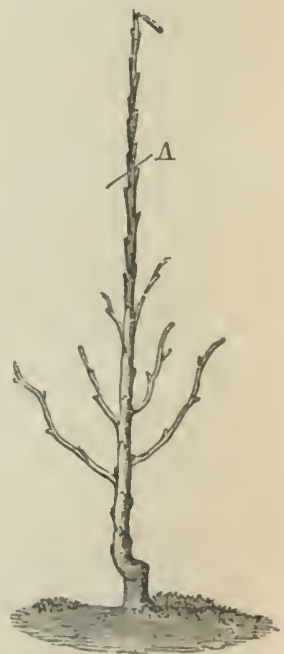

such a manuer as to need uo repetition, and so that only the gentler restraints of summer pinching, and the pruning of young shoots, will be needed, to induce a liamlsome shape. The grreat diflerence between the cflects of two methods of pruning may be seen by refierence to the fignres. Fig. 30 represents a maiden plant or tree of one year's growth from the lond, with a mark at $\Lambda$, to indicate the place at which it is tiequently shortened in the fall pruming. 
It should have been shortened in at about half its height. The cross lines on Fig. 31 indicate places on the limbs where the usual improper pruning would - be performed. Both of these Figures exhibit incorrect modes of shortening, which will indnce a growth that becomes very difficult to shape into regularity. To form a pyramid of the tree shown at Fig. 30, its branches should be shortened to two or three buds, and the young shoots formed from these, pinched during the latter part of June, to induce the lower dormant buds to push out. But the method most certain of producing the basis for a wellshaped pyramid is the summer pinching of the maiden plant, as shown at Fig. 31, which is the form that the tree at Fig. 29 would have assumed in autumn, if pinched during the preceding July. This last-mentioned tree will now need to be shortened-in much below the mark at $A$, to induce lateral shoots in the proper place to form a well-balanced pyramid. So general rule for pruning trees before planting would accurately meet the necessities of each case, but it will be safe to recommend, that when branclies or branch spurs have not formed low down upon the stem, ol when the tree is not stocky and vigorons, or when the roots are much shortened in digging, the tree should be ent back one-half of its height. No one who prizes ultimate exeellence more than the present appearance of his trees, but will prune mereilessly all the parts that confliet with their perfection of shape. In most instances, trees are retarded for two or three years by permitting too large a quantity of toliage to remain. Too many branches are demanding a mere 
misistence, when a fower number would find nutriment enoung to insme a vigngous grrowtle.

When the pramidal form is not desired, it is still necesary in freserve the balance between the roots $\therefore$ inl the tor, of the tree.

Most horticulturists have stopped lere in their in-metions relating to planting; but root-pruning will he fumnd fully as impretant in practice as the purper - Haping of the top). Womded ronts must not only he mmored, and the ends of all the eut nr broken romes - moothly pared, but, in many cases, all the roots nuay he shortened with protit in the growth and foniting of the tree. Wheu large mass s of fibrous roots are formerl, as un the quince and root-pruned pear stocks, they hecome so matted ingether as not easily to be - warated from cach of her hy carth in planting. When rumts are placed in contact in the soil, they will usually become diseased, and luse their power of aftureling - ll-tenance to the tree.

liefore the tree is planterl, the fihres and sueculent spongioles shomld be slortened to an inch in longrth, and thimed sufliciently to admit of lecing realily sep-

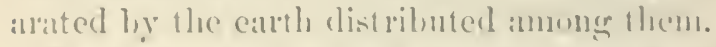

It is now the receiver fractive amomer lueticulturints to plant the peale or quince root so decep as io ance the place where the pear-bul was inserted. Py this metluml, as the guince stoek lias heen hudeled at lo:let fom imelus ahove the gromml, we adel six inches th the deprith of the lont, plumgring into at colder soil thrie rouflets which lawe heen formed uear the surfiuce, and are not alipted to that dejull, and thus 
violating some of the delicate conditions of vegetahle life.

In replanting trees on quince stocks so decp as to cover a portion of the pear, it is best to prune off two or three inches of the main root. The reeent removal of some himndred trees, which had been planted out three or four years, gave me an opportunity of exanining the effect of deep planting. In almost every instance where the quince-roots had been buried six or eight inches deeper than the natural position, I found the lower layer of roots inert, and in many ca cs diseased, and it has now become my practicc to remore three or four inches of the lower portion of the main root with a fine saw. For trees upon the quince stock, no fears need be entertained on acconnt of the reduction of the roots, as the portion of the stock buried will soon be covered with fibres and rootlets.

After having been once root-pruned and planted ont, trees may be remored within three years from their root-pruning, withont greatly reducing their tops. Ordinary nursery trees must be severely pruned in their branches, in order to reduce the eraporating surface of wood and leaves to a limit that will require no more sap than the roots are able to furnish. Suppose a tree capable of evaporating two gallons of sap each day, through its leaves, is provided with roots sufficient to furnish this amount. Now, if the tree be removed, and nearly half the roots are mitilated and lost, while all the branches and leares are left entire, it is plainly to be scen that the latter wi!l continue to require a full supply of sap, while the diminished roots will be incapable of supplying suffi- 
cicnt moisture to prevent the tree from drying. It must he distinctly kept in mind that the formation of roots is in almost exact ratio to the amount of healthy branclies and foliage, and that every branch has its counterpart of root below the surface of the soil.

IREPLANTIXG TIE PEAR TO FORM FIBROUS ROOTS.

Some of the English, and other foreign nurserymen hare a scale of prices for trees of the same variety, graduated by the number of transplantings.

The tree is lifted at the end of the sceond year, the roots smoothly trimmed, and replanted immediatcly in an adjoining treneh. As each snceessive row is remored, the ground which was oceupied by it is opened for the reception of the next. The benefits derived from this process consist in the formation of large numbers of tibrous roots, which push out at the extremities of the pruned roots, and the consequent safety of remoral. 'Two or three transplantings of the Peal tree will produce a mass of rootlets and sjungrioles that somewliat resembles an enormons head of hair. The transplantings occurring at intervals of two or three years, will occasion at ench removal more and more surprise at the immense mass of roots, and the great change which will have taken place in their cluaracter. Instead of long straggling latcrak, streteling away from the trumk for several yards, masies of immmerable fibres will be fonnd, contaned within at compass of three (1) fum fiect, and instcal of the feeble shoots that are usually fruduced after removal, the same searun 
will often exhibit a rigorous growth, and ripened fruit.

\section{IIEELING-IN.}

When trees arrive at an inconvenient time for their permanent planting, tlicy should be immediately heeled-in. A trench should be dug nearly a foot deep, taking care to throw all the earth upon one side, to form a bank sloping to tile bottom of the clitch. In this trench place the roots of the trees close together, permitting their bodies to recline against the bank; then sprinkle the earth upon the roots as in planting, taking care to leave no spaces for mice to liarbor in, or which will expose the roots to frost, or the drying influence of the atmosphere. If the trees are to remain any length of time, and particularly through the winter, this is a libor that must not be slighted, and the trees should receire nearly as much care as in permanent planting.

When slightly inchined, the trees are more readily corered, and can be remored with less injury to their roots. If the trees in this position should commence growing before it is conrenient to plant them, the growth may immediately be checked by lifting them sufticiently to detach the soft spongioles forming.

\section{TREATMENT OF WITHEIED TREES.}

When the roots of trees that arrive from the mursery appear dry, if the branches are not withered, it will be sufticient to plunge them for an hom into a thin mortar of clay or carth; but when the trunk and branches present a shrunken and withered appearance, they should be at once laia at length in a shal- 
low trench, ecrered lightly with earth, and left from three to ten days, accordingr to their condition, mutil the bark is swollen finl and plump. The woort of plants is not a solid structure, but is composed of cells or short tubes, separated by woody fibre. These cells are the arteries and reins of the plant, in which is conveyed the sap which hardens into wood and bark, or is developed into fruit and leaf.

When the tree has become dry, these cells contract so much that sap camnot pass through them, and artifieial means, such as are abore describel, become necessary to restore their functions. Trees which it is necessary to treat in this manner shonld be shortened in to a greater cxtent than is needful in other eases, and when planted, the gromd should be well mulched. Frequent sprinkling and watering of the branches and foliage of injured and puorly rooted trees is found much more useful than the profuse pouring of water upon the roots-by preventing the evaporation through the leaves from exhansting the supply of sap

\section{PIANTTNG.}

Many persons magine it necessary to clnose a wet day for planting trees. On a light sandy loam, little injury wonld result, perhaps, from the selection of Euch a day, hut for planting upon a strong loam, or clirey soil, no cluriee could be more injudicions.

The carth fills in mortar or in clods upon the roots, presing them down into dose contact, instead of being distributed hetween them, and thus separating each ruotlet from its follow with intervening earth that would soun be tilled with fibres. 
The gromnd, even of a light soil, is trodden hard when wet, and is thus left in the most unfit condition for future cultivation. Contrary to the usual belicef, she day selected ought not only to be dry, but it least two or three days should have elapsed after the falling of rain, before planting is commeneed. The boil being now prepared, and the holes dug aecording to the directions giren, let one person hold the tree in an upright condition, and another with a slaking motion of the shorel sift the monld among the roots, ooceasionally stopping to lift those roots that hare fallen below their natural position. The necessity of attending carefully to this latter direction will be seen from the fact that the roots of trees, especially when fibrous, are thrown ont in layers so as to reach different strata of earth, and that no two roots can be found growing in contact. Consequently, when the roots are pressed down in a mass, the energies of the tree must be greatly erippled, and its growth retarded. When the roots have been partially corered by shaking in the pulrerized earth, the person holding the tree may, by a slight tremulons notion, sift the finer particles among the fibrons roots, and thus separate them more completely; but carefully avoicling to lift the tree so as to alter its level, or tear its roots. To prevent the formation of a hollow beneath the forked roots of a tree, a mound of firm earth should be formed in the hole upon which the tree is to be planted, and care obscrved to press the earth into any space that may remain.

If the tree is found to be plinted too deeply, it must not be lifted, with all the weight of soil npon it, 
until it has reached its proper level (as this areless plin would displace all the roots, and entirely ruin the more alelicate ones) but the earth should be carefully remored, and the tree reset. 'The hole should be tilled, as far as possible, with the top soil; and to obtain a -nfficiency for this purpose, the soil shonld be remored from the adjoining surtace, and intermingled with a purtion of the subsoil, to fill the hole.

If the carth immediately around the roots of a tree is poor, the most skillful cultirator cannot remedy the defect without removal of the tree; but when an infertile soil is upon the surface, any ordinary laboler caln improre it by manuring.

The loose carth with which holes are filled in planting trees, must not be pressed upon the roots by treading, or other means, muler the pretext of tixing the ree firmly in its plice. The more loose and porous the soil is left, in filling the hole, the more pertectly will lle next rains wash it among and around the roots, andl solidify the gromud. It convenicnt, a few pails wi water wonld imperfectly imitate the effect of rain, and prove temporarily beneficial. To prevent the dimplacenent of the tree ly heary winds, and the con-equent racking and fracture of the roots, a mound of eatll should be raised against the body, to remain through the winter, and for a month or more in spring.

IPAN OF ARRANGING PRAR GROLNDS.

liy training all the trees of a plantation, whether on (Mince w J'ear louts. als lyamids or low stamdards, int little care need be obeerved to preserve greater histances between thrise on P'ear stucks. The best 
arrangement is the quincunx, as it affords a larger space to trees planted in this manner, than set oppo. site each other.

By this plan, the trees will be arranged in rows in five different directions, from which fact the method takes its name. In planting, the ground shonld be laid off by a plow in furrows, at the proper clistance. A furrow should then be plowed at right angles to the former, at one end of the plot, where the outside row of trees is to be planted, as in Fig. 32. The distance at which the next parallel furrow is

to be plowed, Fig. 32.

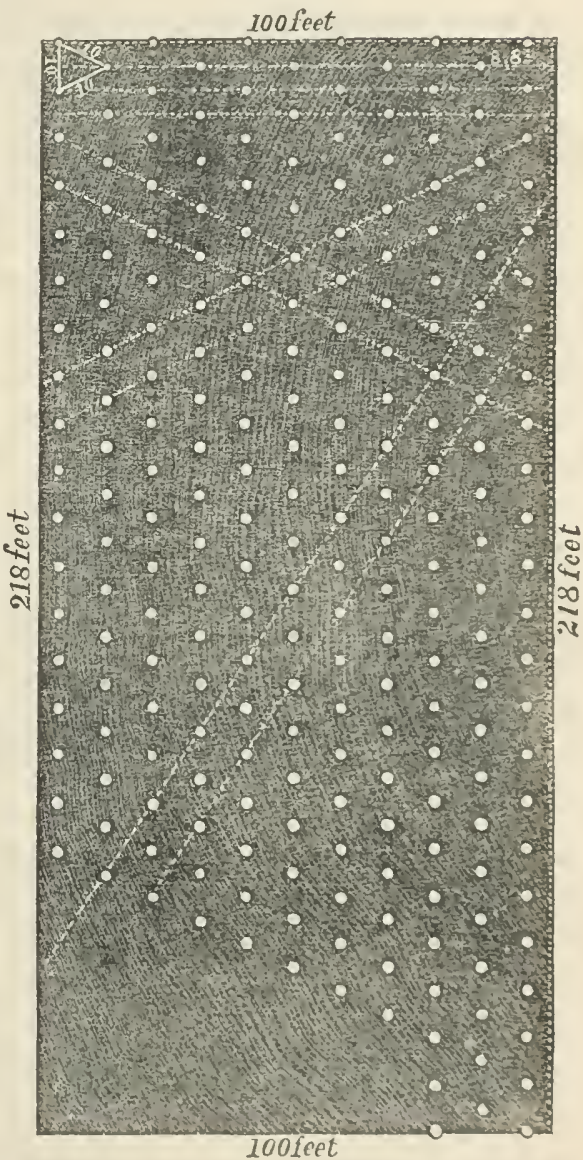

should be one half of that at which the trees are to he planted in the rows. That is, if the rows are fon feet from catch other, and the trees are to 
be planted at ten feet apart in the rows, the erows fur. rows must he pluwed live leet distant finm each other.

Every alternate erosing will indieate the pusition of a tree, unitting the first crosing in cach alternate row. It the trees are planted quite up to the boundary line, this plan wnuld grive us five rows of twentytwo, and six rows of twenty-three trees cach, or an

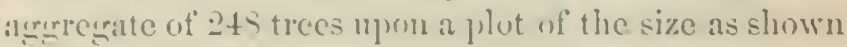
at lig. 3.2, which represents lalf an acre of gromdalthough the aldition to onc side of this of" an cyual plot of ground would be capulile of containing only 2.).) trees. If trained to hrancli near the gromml, and projerly pumed, tï) trees may he grown and truitcel upon an acre, for many years, withont crowding. ly. this method-impruperly termed quincumx-each tree wonlel stand ten fiet firon its neighlnons in the same row, and a trifle over twelve lecet firom the nearest in tlee adjacent rows.

The true quincunx arrangement is formed by placing lle trees at epual distamer's from each other in crery direction, amel when the distance proposen is ten fect, it will be neecestry that the rows shomble lad wut at eight fecet eight inclies apont, and the trees planted ten fiet apat in the rows, as represented in

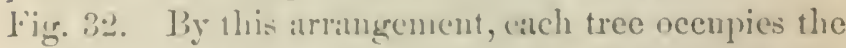
centre of a hexagon of expal sicles, and is consequently crpuidistant from all the arjacent trees-exactly ten feet separatiug cach tree in the plot from ite neigrlibors.

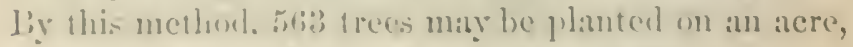
a we sain - pale for three alditional rows.

For a jeas garden, I have lomml ten feet to be an amplle distance; and for planting an acre, would recom- 
mend that the eleven trees at each end of the plot, and one entire row of twenty-three trees, should be omitted in planting, and that the space occupied by the row be divided on each side of the plot, so as to leave 2 , clear unocempied space of tive f'cet arround it. Five hundred trees will thus find ample room upon an acre; and may yield their fruit to one greneration before they will give evidence of being clowded.

A plan very frequently adopted is, the planting in borders on either side of a path and around garden squares. The borders should be deeply tilled and rich, and the trees may be planted quite closely.

A beantiful effect may be produced by preparing, on each side of a path, a border of not less than twenty-five feet wide, in which are to be planted finittrees, in a form to produce tlie effect of the sides of an amphitlieatre. In the sirle of the border furthest from the path, are to be plinted the most vigurons varieties of pear trees, on their own roots. Next, and at a distance of not more six teet, shonld be planted a row of less thrifty linds, on quince roots. Each snececling row should be comprosed of rarieties less vigorous in their growth than the preceding, until the front row is reached, which should be planted with dwarf apples.

The ontside row may be planted with the Vicar of Winkfield and St. Michael Archange-the second with bartlett on pear, and Urbaniste on quinee stocks, the third witl Duchesse and I.onise Bonne de Jelsery on quinec, and the fourth with Flemish Beanty and Winter Nelis on quince. 
I EITII UI I'IANTIAO.

No part of fruit culture has attracted more attention, and clicited more speculation, than this. In one point all are agreed, that, with few execptions, fruit-trees slould never be planted deeper than they grew in the murecry. The part of the tree ealled the collar, where the birk of the roots meets that of the trunk, the natural pesition of which is a little lectow the surface of the gromul, maths the linit to which it shomld he usually buried. Although the earth may be temporarily leaped higher than this, around a tree just planterl, yet it should gencrally le removed soon after growth commences.

A A.r. Comstock created some sensation, nut ]ong since. by his elain to hate discovered the grand secret of sucesstiul firnit culture. He acepuired some money, and a sort of fame, by lectures upon what he termed the science of Terria-culture-or, cultivation withwit disturlung the rootlets which till the soril. His thenry was, that a tree planted below its natmral depth there out a new stratum of rents, by which the equilibrimm was lost, and it became thenecturth it mained tree, incapable of predneing its maximum of firut. But lis theory wats only a repetition of the old story of lomman creror-a part laken for the whiole.

In planting in a dry and decply pulverized soil, the prar tree maly with safety he plateed lower than its original pustion. Acermeling to my own experience, it is quite exsential to success, alfer removing at fear tree from al heary to a lighte soil, that it be 
planted one or two inches deeper than originally grown.

But in wet or compact soils, or on those composed in great part of organic matter, like the Western prairies, a preferable plan is, to ridge up the soil six or eight inches ligh, by backfurrowing, and in the em. bankment plant the trees. Some persons hare practiced with suecess, on wet or elay soils, a plan of planting on the surface of the ground, and corering the roots, by heaping up a mound of carth much wider than the space occupied by them. This may serre temporarily ; but the plan is a mere shift to escape the labor and expense of draining, and permanently improving the soil.

But to the rule generally established for the depth of planting, there are two notable exceptions. First, while the Peach, Cherry, Plum, and Apple, camnot be planted much lower than the collar without injury, the Quince, the Griple, and the Pear on quince roots, are, from the structure of their bark and wood, capable of adapting themselves to a depth of planting much lower. Second, when the soils liave been deeply trencheel or snbsoiled, their level is much higher than in their former state, and in compacting, they will sink away from the ronts planted in them, leaving the njper ones exposed, muless the trees shonld be plinted deeper than grown in the nursery. Tery tibronsrooted trees obtain a better hold of the soil, and are carried down with it. In plinting grounds deeply prepared with pear trees. I lave found those on the quince stock, by their filurous roots, able to maintain their relative position in the soil, while in its 
compacting, the troes on perr stock alternatiug with the uthers, wonld be left two or three inches out of the ground.

CLITHATION OF THI: PliAR ORCHLRD.

A reputation for bad mamagement, and perhaps a residence in a lunatic asylum, could not be more readily obtained by a firmer, than to persistently practice the growing of weels and grases in his potato and cormficlds, seeding down to rrists the grarden which lie had just planted with regretables, or turning his cattle to graze in lis ripening rrain.

Yet, scarcely one in a liundred fiumers but performs every one of these insane pratetices upon his orcliarl and fruit gronuds. Until within a very few years, the orchard was quite as much relied upon for pasturage and grain erops as the meadow and fallow. Hundreds of thousands of trees lave been planted in ground cropped year after year with corn or wheat, that lave made no more growth in five years than might liare been produced in two. Nothing could be less cenomical, even where only protit wats desired. No reason can be rriven why a ficld of corn and potatoes slould be cultivated with plow and hoe, that is not an epually powerful argunent in favor of the same treatment of young trees; and there are many reasons why the latter will not suceced with gratss and grain, when they would grow luxurantly witl root crops. One of the principal arermments in firvor of the latter juactice may sugergest others to thinking observers. Vegetables grawn for their roots derive the fur greater prtion of their nutrinent from the atmospliere, 
through their broad or luxuriant foliage, while grasses and grains take more largely from the soil. The latter plants not only permeate the soil more eompletely with their roots, but by their taller and denser growth, prevent that free contact of the lower branches and leaves with the atmosphere necessary for the alsorption of mutritious gases, and the deposit of invigorating dews.

The experience of the best horticulturists oonfirms the opinion that the cultivation of the ground, equal to that usually bestowed upon corn and potatoes, compled with the aroidance of any grain crop, will hasten the maturity and fruiting of the Pear, from six to ten years. If the ground is root-cropped, the cultivation for the roots will afford an excellent tillage for the trees, which, for a few years, will but little interfere with the growth of the former. The plowing must be managed with some skill to aroid wounding the trunk with the whiflletree, or cutting and exposing the roots with the share, and the distance of plow cultiration from the tree should be increased each year, to aroid injury to the growing roots. On this account, the surface near the tree shonld not be disturbed more than two or three inches deep, after the latter has acquired considerable size, and this opera. tion should be performed with a digging-fork. Almost. every cultivator of trees has obsered striking instances of the difference in their growth, when enltivated or neglected; but the narrative of one may not be inappropriate. $\Lambda$ few years sinee, a gentleman, having planted a considerable number of pear and other fruittrees, devoted a portion of the ground occupied by 
them to his regetable garden, while the remainder was retained ats a lawn. The trees growing in the trencherd and cultivated garden are handsome pyratmids, ten feet lighl, and in bearing, while those in the lawn, although with a space of two fect around them cleared from grass, have not pereeptibly increased for six years.

\section{MLLCHING.}

No process will more cssentially aid in sustaining the life of a tree, enal)ling it to resist the rude shock of being torn from its native soil, and inducing rigorous growth, than mulching, or eovering the soil with any waste or half-decayed vegetable material. The half-lotted straw of the bottoms of stacks, leaves gathcred from the woods, the refuse elippings and tan-bark from leather factories, are all of value for this purpose. Covering the gromd with these, three or four inches deep, aromul the newly-planted trees, has the effect of preserving a moist condition of the soil, and an eren temperature during the great heat of summer. $A$ most important element in the growth of plants is this preservation of an equable temperature, as may be seen in a cold vinery, where the range of the themometer scarcely varies ten degrees during day and night. The mulching also protects the ground from excessive evaporation; so that, during long periods of drought, the ground remains unifurmly moist and light. To the Pear this treatment is peenliarly grateful, for there are few plants in which respiration goes on so rapidly, and which require such constant supplies of moisture. $\Lambda$ enrions and instructive experiment is narrated. $\Lambda$ pear tree was grown in a large tub untii 
it had obtained a vigorous condition, and when the soil was in a comparatively low state of humidity, the weight of the ressel with its earth and tree was ascertained.

In a warm July day, a giren weight of water was supplied, and the earth protected from surface eraporation by a cover. In forty hours, the whole was agrain weighed, when it was found that seren gallons of water had been thrown off by the leaves of the tree. or more than twice its own weight.

Prof. Mapes narrates an experiment which ho performed upon a pyramidal pear tree three years planted, and seven feet high. A hole was dug beneath one of the largest roots, which remaining attached to the tree, and with all its spongioles as nearly entire as possible, was placed in a pail of water, and the whole carefully covered with a blanket. In twenty-four hours the tree was found to have appropriated nearly two gallons of the water. No small benefit derived from mulching, is oring to the fact that trees so treated need no watering; and the excuse for the barbarous practice of frequently drenching their delicate rootlets with cold water is removed. Poorly-rooted trees, or such as liare been cxposed before planting, or are quite withered and dry, or indeed all plants which survive transplanting with much difficulty, ean in many instances be saved by mulching decply for fire or six feet about the tree. The loose texture of the mulch does not prevent atmospheric contact with the soil, and being constantly damp, both the mulch and the cartli absorb ammonia and carbonic acid rapar. Some varicties of 
pear of great excellence, which crack badly, may bo ripened in pertection by mulching, as the cracking is in some degree due to an insuflicient supply of sap. The mulch not only aets as an ahsorbent of fertilizing gases, but in time becomes itself a raluable manme.

There are, however, some counterbalaneing disidvantages in mulching, which will contine its puretice to the single season of planting. The immense increase of insects, which will propargate in its shelter -the ravarges of mice that find beneath it secmity from pursuit-and the late growth of shoots which it induces, liable to winter-blight, are some of the efiects of its continuance.

After muels experiment, I am convineed that the best mulch for any other than newly-planted trees is a soil often stirred with the dew upon it.

\section{CROI'ING 'THE GIOLND FOR A MLLCI.}

A very convenient substitute for litter, and one from which none of the evils noted will result, is an early crop of some of the broad-leared reggetables. Tumips, beets, and potatres, are valuable in the order they are mentinned for this purpose, and would in most cases repay the labor of cultivating the trees on them. The first two have the additional advantage of peuetrating and loosening the soil without bruising the roots of the trees; and by the superiur conluess of their leaves to the nierhtair, condense the humidity in currents of atmospliere lassing over them, in the shape of dew, which would liave fillen upon the plowed field or the dusty road; and thus assist in nourishing the tecbler foliage of the newly-planted 
trees. Notwithstanding all these derices for preserving moisture in the earth, the golden rnle of agriculture should be remembered. Soils disturbed when dry, or during the heat of the day, loose their moisture; but plowed or hoed in early morning, more moisture is aequired.

SPECLAL MANURES FOR THE PEARS AFTER PLANTING.

That a Flemish Beauty or a Napoleon will be produced in perfection in one soil, while, a mile distant, and in one of precisely similar appearance, they fail to be anything more than second rate, is a mystery that has hitherto mocked our investigation. It is unfortunate that nostrums, based upon some degree of knowledge of the necessities of the case, have been palmed off upon the community, deterring many persons from further investigation; still, when we rocollect what science lias done for human development, it may reasonably be expected to perform much for vegetation.

If it is remembered, that it is a great thing in an cxperiment to have Nature upon one's side, the analysis of the Pear will suggest the course onr investigation should take.

It is not unfrequent that trees exlibiting every quality requisite for fruiting fail for mally years to produce a single pear, when the applieation of a bushel of lime, a dressing of wood-ashes, a small quantity of bone-meal, or of iron filings, or refuse sand from the foundry, has brought them into immediate fruitfulness. I have seen some very surprising eftects of some of these materials, in the vigorous growth and fruiting 
of trees hitherto barren. It shonld he understood, that a tree can no more grow, and produce fruit, whin on of its dements is lacking, though all the other's are present, than a house can be built, when all its materials, except the nails, have been obtained.

Mr. Dowxrag was of the opinion, that bones finely ground and mixed with wood-ashes, wonld prevent the leaf-rust; and several nurserymen who have used the compost seem to adopt the same belief.

Mr. Barix very tersely and happily remarks: "Bone-dust, blacksmiths' einders, muck-lime, woodashes, and half" a dozen other things, have been recommended to be compounded, in pecks and lialf-pecks, all with a view to remedy the rust, or leaf-blight, that no man can say originates in any defect of the soil." But the failure of specific manures to produce certain results, for which no rationale founded in natural science conld be given, ought not to deter us from investigation in a philosophical manuer. Some simple facts illustrative of the ralue of scientific knowledgo in the management of the Pear may be stated. On a plot of rich ground, where blight had year after year affected the Pear, its further ravaces were prevented by a large application of lime; this wats accounted for by the destructive action of the lime upon the exeessive organic matter of the soil, thus inducing a more stocky and well ripened growth. Dr. N. R. T'ift, of Onondagrl, so changed the appearanee, in shape and size, of the fruit borne on a Virgalieu pear tree by a very large application of leaclied ashes, that specimens of it received the premium from the American Institute as the brst new table-pear. 
Some remarkably fine Bartletts, and handsome specimens of other varieties, haring attracted attention, they were found to have been raised by a blacksmith of Newtown, Long Island, from trees that received the refuse of his forge.

At the Exhibition of the Massachusetts Horticultural Society, 1857, which was pronounced by Europeans superior in its show of pears to any which could be made in Europe, the collection of $\mathrm{Mr}$. Bacor was awarded the highest premium for the ten best varieties. These pears, the most beautiful in color, regnlar in shape, and the largest in size of their respective varieties, were grown over a salt marsh which had been filled three or four feet. I ascertained, on inquiry, that several other gardens, which ocenpied similar positions, wore remarkable for the fine pears grown upon them. The Napoleon, Soldat Labourem, and other new varieties, that liare generally proved but secondrate, have been produced of the very highest quality, when the trees had been liberally treated to superphosphate of lime.

Dr. Inndery, author of a treatise on "Tegetable Physiology," and a museryman of great experience in England, strongly recomments the use of superphnsphate of lime for newly-planted trees, as it excites the rapid formation of fibrous roots, and thens provides for supplying the great waste of fluids, which is carried on with such rapidity from the leares and hranches.

These facts, even if they teach us nothing positive, certainly indieate the direction in which our invest. igations should be pursued. 
INTIOOLITING OLD TREES.

The canse of the want of rigor, slow growth, often of entire cesation of increase in pear trees of considerable size, is generally the exhaustion of the soil within the range of their roots; the whole energy of tle trees being deroted to sustaining the fruit buds and spmrs, no wood growth can be made while this exhaustire fruit production proceeds. There is also an entire suspension of the absorptive and perspiratory functions of the bark caused by the incrustation of clead bark, moss, and fungi that cover the tree. The aged roots have lost their radicles, and do not possess the power to push out spongioles into new and unexhausted soil.

These conditions suggest at once the remedy. A trench should be dug around the tree, at about as many feet distant from it as there are inches in the diameter of the trunk, thongh rarely farther than six or eight feet. This trench should be at least two or three feet wide, aml as $(l e(y)$ as the roots penetrate, the latter being jurmed off with a smoth cut. The sods around the trees slomld be pared off to the depth of four or fire inches, and mixed with manure to fill the trench, and a good grenerous compost of new eartl and barnramel manure should he put around the treo in place of the sols removed. The old and feeble branches having only fruit spurs, should he shortened in such a manner as to form a liandsome top. The rough fungrus bark shunlil he gently scraped away, cure being taken not to expose the vital hate beneath. A better method is to wiwh with strong soap-suds or potish 
water; the old bark will be loosened and pushed off by the new formation of bark beneath.

If the tree is of an inferior or wild variety, the sinaller branches may be filled with grafts, of which a large number should be set, in order not to prime the tree too sercrely, and also to furnish it as soon as possible with new respiratory organs.

\section{GRAFTING LARGE TREES.}

It is a very common result of grafting large trece, that after producing an apparently vigorous gromth for two or three years, they exhibit tokens of disease, and finally die.

There is little doubt that this is the result of too great an interference with the structure of the tree, by cutting away nearly all the top in a single scason, for the purpose of grafting. The roots prepared by a vigorous top, with an abundance of rich condensed sap, are, in their turn, ready to offer a copions supply to the top, for elaboration, and oxygenizing by the leares.

Thrown back or suspended in the structure of the tree by this severe pruning, the sap becomes condensed by eraporation, and remains clogging and suffocating the vital energies of the tree, which makes strenuous efforts to supply itself with the organs of respiration.

The true method of grafting trees more than five or six years old is, to remore not more than one-third to one-half of the top in nne season, and set a rery large number of grafts in the limbs, or to dig a trench abont the tree, and thus shorten the roots to prevent too largo a supply of sap. 


\section{PART IV.-THE PEAR UPON THE QUINCE STOCK.}

OFITE OF THE QLINCE.

Thx office of the Quinec, in its association with the pear tree, does not seem to have been generally considered. It is the only one of our fruit-trees which is readily propagated from layers or euttings. Of one thousand euttings of other species of fruit-trees, planted in the ordinary manner, but a very few would strike root, while of the same number of the Quinee, but very few would fail to grow. The portion of quince on a quince-rooted pear tree, which has hitherto served as trunk, will, if covered with soil, in a few days, throw out rootlets, and theneeforth perform the oftice of root to the tree it supports. It seems therefure, incredible, that with these fuets in view, intelligent cultivators should have failed to provide the conditions for the Quince to fulfill its oftice.

By planting so deeply that the Quince is entirely beneath the gromnd, all the objections to its use in propagating the Pear are orercome. The principal of these objections are: First, that the Pear grown on the (guince is short-lived. Sirond, that the trees often break at the junction, from imperfect union. Third, they are always of small size. Fourth, that the Pear 
outgrows the Quince, and produces a deformity. All these difficulties have been lemedied, or aroided altogether, by planting so decply that the Quince is entirely beneatl the ground, for the office of the Quince is entirely as a root, and never as a trunk.

CALSES OF THE FAILURE OF THE PEAR ON THE QUIACE.

The introduction of new plants, or of novel modes of cultivating old ones, is always attended with many failures, arising from insufficient knowledge of the conditions necessary to the suecess of the experiments.

The value of the Quince as a stock for the Pear has been a subject of much dispute; but candid observers, aiming only at the exact truth, liare settled into the conviction, that its failure for this purpose has proceeded in every instance from some neglect of the necessary conditions of its growth. The causes of failure may be summed up as follows:

First-In the heat of the first demand for pear trees upon quince stocks, many thousands of the common or Portugal Quince were used. This rariety is entirely unfitted for this purpose, by its slow growth, and slight assimilation with the Pear, and the small size it attains.

Second-All the varieties of pear were at first indis. criminately grown on the Quince. without regard to their fitness. But it is now well ascertained that only a linited number of our finer pears are entirely adapted to the Quince.

Third-The office of the Quince in the double tree being wholly mistaken, it was plinted as it stood in the nursery, often with the jumction of the two species 
from three to eight inches abore the soil; and in alldition to this misclicvous practice, the tree was not unfrequently trimmed up as a standard. This metlod of pruning gave the top, when large, a great lever power at the ground; and the trees, mable to resist the forec of the wind, often parted at the junction of the bud with the stock. If the tree survired, it was often a monstrosity of growth, the pear swelling out to twice the diameter of the quinee.

ADVANTAGES OF TIRE QULNCE AS A STOCK.

The conditions and adrantages of the use of quince stocks, liave been so fairly and clearly set forth in a communication of Mr. Lous Berchanss to The Agriculturist, that I shall insert it here. Mrr. Breckuns lias deroted a life of great activity and intelligence to experiments upon the Pcar-enjoying the personal acquaintance of those gentlemen, both in Europe and America, whose names will always be associated with its culture. His collection is large, and cmbraces selcetions fiom the best scedlings of VAx M[oxs, Es. risix, Bront, and others. Ilis mreat experience entitles his testimony to the higlest consideration.

In answer to the vexed question- Will pears budded on the Quince succeed?-Mr. Brenckunss says: "I have no lesitation in saying: 'Y $\mathrm{cs}$, they will;' and often better than on pear stocks, and they are liss subject to b7iglet. I know that I lo not agrece with the opinions of Buy late friends VAN MLoss and Esrrers, who never would admit a ruince stock in their experimental gardens. I respect their memory, but cannot lielp) considering their opinion as a prejudice. They had 


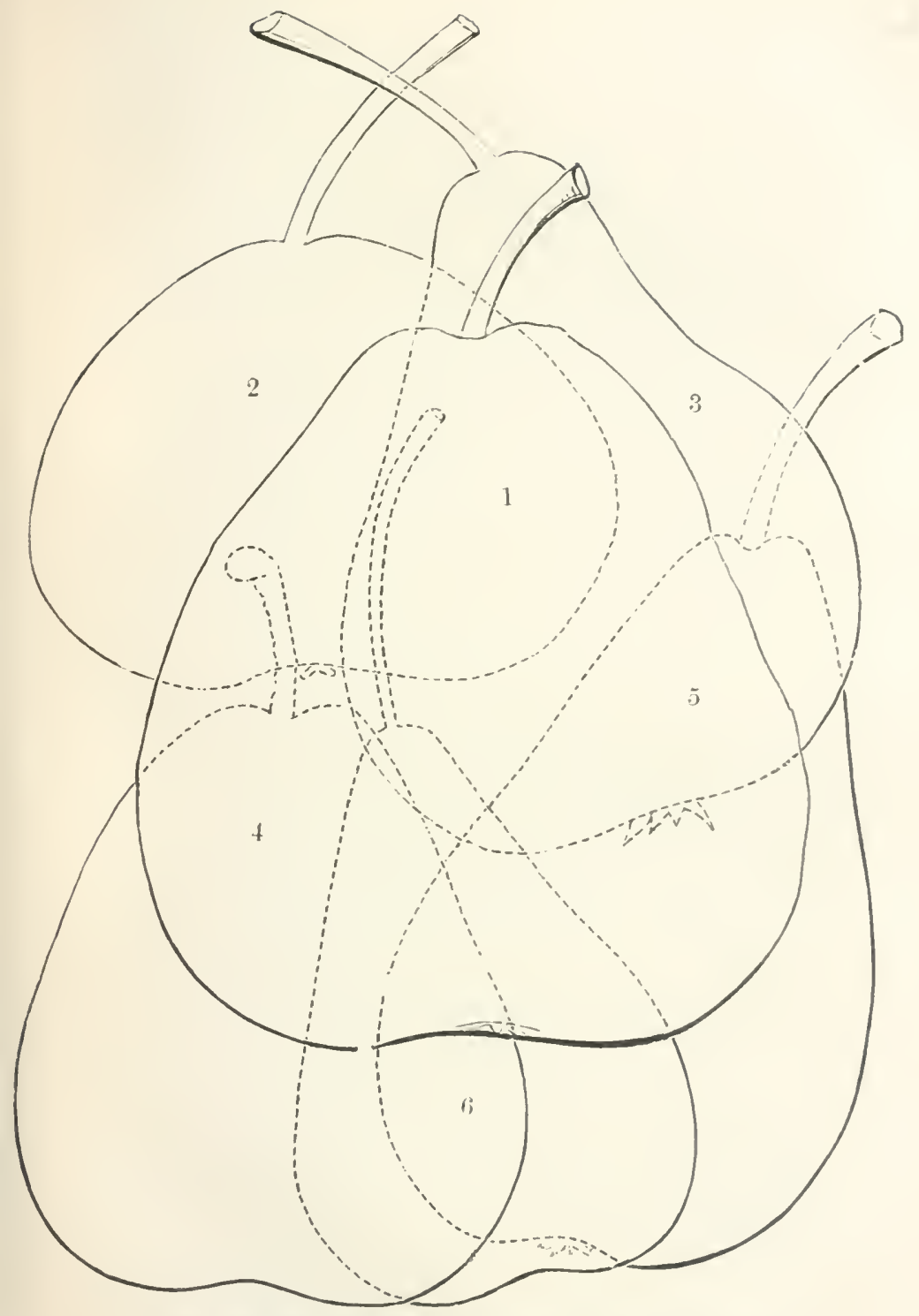

GROUP OF FINE SLMMER, ATTUMN IND WIXTER PLARS.

Selected and Draicn by Mr. L. Berckmans.

No, 1, Niles.

Nin. 3, BFERRE D'AMALIS.

No. 5, St. Nicuotas; or. Dichesse d'OrLeass.
Non Frtox.

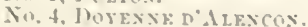

Niv. di, Rostikzer. 

not found the good quince stock, and, perhaps, did not know how to plant quince-grafterl trees. Unless the proper quince stock be used, no good result need be expected. I have seen some singular mistakes in publications, for want of proper attention paid to the question, whether trees had becn budded upon the Angers, or upon the indigenous quince, the latter being very inferior, if not wortlless. The quinee stock for nurserics is produced from the twigs or branches heeled or laid in before winter, and planted carly in the spring. This operation succeeds better in damp and cool climates, and in sandy soils, than in this part of the United States. Therefore, most of those plants are imported (chiefly from France), althongh they can be produced here, with proper care, in soils fitted for them.

"At present, my best trees are on the Quince; and my best fruit also. Those who would successfully cultivate the dwarfs must pay attention to the following rules :

"1. Have a good, substantial, rather deep soil, with porous or drained subsoil.

2. Select the good Angers or Orleans Quince for stock.

" 3 . Plant no other raricties than those which succeed on the Quince.

"4. Plant the trees deep enough, so that the place where they liave been budded shall he at least three inches below the surface of the soil. In rolling ground, corer with stones, or damp monld, so as to preveut the washing away of the light soil.

"5. Keep the weeds down. 
"6. Tieep the hranches low, and make a pyramidal tree, hy julicions lunuing once or twice a year. A tree with at heary, high top, must not be upon the Quinec. Lerels or gentle slopes are better than hills or rolling grround.

"It is al fortunate circumstance that most of the best market varieties are also best suited to the quince stock. Very often the gralted tree, when placed in silicions (sandy) soil or loam, furms its own roots just where it has been budded; and then, with the steadiness of the pear stock, it retains the fertility of the Quince.

"Mfuch has been said about the short-living of the quince stock. If properly planted in genial soil, which is not exhansted or imporerished by interrening ficld crops without a reasonable supply of manure, as most of our apple orchards are; if free from ill weeds and shrubs, and other drawbacks, the quince-grafted tree will thrive for fitty year's or more. Some actual facts will prove what I state. Hon. M. P'. Wrever has in his garden, in Dorchester, trees which he bought from the widow of Mr. Palisistrisi, Long Island, some twenty years agn. They have yiclded fine crops almost every year. Some have been recratted with new varietics; one of them with Beurré Clairgeatu, which bore this year between one and two bushels of the finest and largest pears. These trees look healthy, despite all their mutilations, and there is no reason to anticipate a climinution of growth or cropls. Thues trees are on the Quince, but they have been planted by a inan who know's how to manago trees. 
"In the same garden are some fine Urbaniste treesa part on the Pear, and \& part on the Quince-planted in the same spot, in the same year. Those on the jear roots are now beginning to bear fruit sparingly; while the others, on quince, have yielded bushels of fruit for the last seven years, and are actually loaded with a splendid crop. All are equally healthy ; but, those on pear stocks, not laving exhausted part of their vigor in the best marketable produce for years back, are rather more vigorous. By thinning the crop early, so as to make it moderate, those pyramids may be easily brought up to the full vigor of their unproduetive neighbors. Now eomes the important question:

\section{" "Will quince roots do for orchards?"}

For oreliards, as we find them on most of our farms, a promenade ground for cattle, a dreary waste of ill weeds, badly eultivated and shallow soil, stagnant water, injudicious selection of raricties, and more injudicions pruning with axes or dull chopping-knives - no, sir! No fruit-tree of a refined class, no tree of any value, will do in such conditions. One halt of the trouble, manure, and labor, which a poor rineyard requires in Franee, would make a thrifty pear orchard, and would certainly pay better.

"Let us look at some tine nurseries (schools) or orchards where specimen trees are enltivated with eare, and in proper soil and localitics, and fatets (those stubborn) things will soon bring convietion in the place of doubts.

"Messrs. Elwarger \& Berm, and others, in Rochester; Mr. Wildere and Mr. Hover, near Boston; Cir.s. 
Dowrixg, in Newlurgg; Dr. Graxt, near Peekskill ; Mr. Rism, Elizalbethtown, N. J.; and many others, cultivate the Peall wn the quince stock with the best results. It Mr. Chas. Dowsung's, where every fruit and flower is cultivated in perfection, the surfiace of the gromed in the dwart orchards is covered with straw, refuse hily, dice, and no care nor cultivation is required; no weeds find their way through that carpet, renewed or supplied with new straw or brush erery two or three years. Mr. Downisg seems to be perfectly satistied witl his system, and indeed he must be.

"In cunclusion, let me say, that when one expects to reap the fruit of industry, he needs to gire the proper attention to it; if he expects a firnit-tree to yield crops of the most refined firuit, and to grow as a maple or a ceclin in the woods, he is badly mistaken. 'The old saying, that "a tree must take care of itself," is nonsense, when applied to fruit-trees of inproved kinds. It would do as well to plant dalilias or prairie roses in a swanp), or among thistles and briars.

"He who wants large crops of pears, indifferent in size or quality, maly plant all his trees on the pear stock, in decp soil; but he has to wait fron ten to fifteen years. If you want large, fine fruit, which, in fact, pars better, with less trouble and expense, select your varieties on the Qunee. 'These will often hear the first yeat, and always the third or fourth from their planting. If I hat thirty trees to plant, twenty should be on the (aninee, the bilance on pear stock.

". Some varieties will not grow upon the Quince, but even these do well double worked-that is, budded or grifted upon a variety worked already upon tho 
Quince and succeeding upon it. The French, call it intermectiary yrafting.

"In planting orchards, the same care and the same digging is required for a standard as for a quince stock, but how different the result? Ask Mr. Hover, and other's around Boston, from which they derive their largest profits. They all agree that the quince root has paid the soil, the expenses, tree and all, long before a pear stock has shown any sign of bearing.

"Below is, according to my own and my friends" experience, a list of varieties. which will do for the market, till new and as good varieties can be added. We must consider that the introduction of new varieties of fruit into the market is not an easy thing. Those named below are also the best adapted to the most of the States between thirty and forty degrees of north latitude.

"I.- Varieties of Pears Whicil do WELL ON THE PEAR STOCK, OR WHEN DOUBLE WORKED.

"Those marked $a$ do not suceed well on quince stocks. Those marked $b$ do bear as early and as well as others on the Quince. They are arranged according to their value for gencral cultivation, market purposes, \&c :
b. Bartlett-Sept.
b. Madcleine-Aug.
a. Lawrence (often good on Quince)
a. Seckle, (sometimes does well on $a$. He:theot-Sept. Quince.)
b. Benrré Clairgean-Oet., Nor.
a. Columbia-Nor.
a. Dix-Dec.
a. Dojenue Boussoek-Sept.
a. Hondaga-Oet.
a. Kingsessing-Sept.
a. l'ratt-Sept. Oet.
- Philadelphia-Sept.
h. IBuflim-Sept., Uet.

And miny others. The above are all good-looking fruits, and of course will sell readily. 
"II.-VARIETIES AIAITED TO TIE QEINCE STOCK, WIICH ALSO DO WBLC ON THE PEAR STOCK.

Louise Bonne de Jersey - Sept., Abbott-Sept.

Oct. $\quad$ Jelle Epine Dumas-Dec., Jan

Duchesse d'Angouleme-Oct., Nov. Beurré d'Anjou-Oct., Nov.

Jeurré Diel-Uet., Dor.

Viear of Winkfeld-winter.

Urbaniste-Oct. Yor.

leurré Superfin-Oet.

Beurré llardy (or Sterckinan)- $\begin{aligned} & \text { Steveli's Genesec-Sept. } \\ & \text { Doyenue d'Alençon-winter. }\end{aligned}$
Sept.

Glout Morceau-winter."

Flemish Beauty-Sept.

Andrews-Sept.

Kirkland's Seckle-Sept.

Brandywine-Sept.

We think nothing can be more conclusive with regard to this question than the testimony of various indiriduals of note in the cultivation of fruit; among whom none rank higher than Marsmate P. Wruder, whose views are expressed in the following remarks, given at length: "An impression has extensirely" prevaled unfivorable to the eultiration of the Pear on the Quince. This has arisen principally from an inproper selection of kinds, or firom injudicions cultivation. There are, however, three considerations which are absolutely necessary to sucecs, viz., a deep, rich soil, the planting of the quince stock entirely below the surfice of the grouml, and a systematic and scientific course of pruning, as the tree progresses in growtl.

"Oljjections to this species of cultivation have been made from the belief that the Quinee was a short-lived tree, and that the crop must necessarily be small from what are termed dwarf-trees. Such, however, has not been my experience. On the contrary, Thave pear trees on the quince root which are twenty-fice gecurs old, and which produce annually a barrel or 
more of fruit each; and for anght that I can see, they are destined to survive as long as any that I possess on the pear root. These may, and probably liare, in some instances, thrown out roots from the pear stock, but whether this be so, or not, instances are not rare where such trees have attained in France the age of more than a leundred years; and we know of a quince tree in Missachusetts which is forty years old, and which has produced ten bushels of fruit in a scason.

"The Pear, when grown on the Quince, shonld always be trained in the pyramidal form. These may be planted much closer than when grown as standards. We have known them to sneceed well where grown at the distance of six feet apart in the rows, and twelve fect between the rows. In this way Mr. Rrvers, the great English cultivator, planted 2,500 of the Louise Bomne de Jersey, and 1,500 Glont XIorcean for the London market. We consider twelve feet apurt, each way, a liberal distance. This would give 302 trees to the acre; and we are clearly of the opinion, that soil and selection of varieties being right, no crop whaterer wonld be more profitable. Such a plantation, with proper care, would yield, in the fifth year, from seventy-five to one himdied bushels of fine fruit. $\Lambda$ s to profit, this will not appear as an exaggeration, when it is known that Glont Morccan pear's, a variety which succeeds admirably on the Quince, have sold, during the winter, reaclily at one to two dollars per dozen.

"We name as raricties which succed well on the Quince the following, and to which might be adked many more: 
"Lonise Bonne de Jersey, Vicar of Winkfield, Duchesse d'Angoulême, Glout Morcean, Passe Colmar, Urbaniste, Belle et Bonne, Beuré d'Anjou, Beurré Diel, Eisster Beurré, Beurré d'Amalis."

The fullowing, from the same gentleman, in answer to the published skepticism of a cultivator regarding the permanency of the quince stock, effectually dispuses of his objections: "I have, in my grounds, many primitive pear trees from ten to seventeen feet in - height, with trunks twenty-seven inches in circunference, and branching at the base from ten to twelve feet; humbleds of these trees are from twelve to fifteen years of age-they have borne regular crops from the third or fourth year after planting, and in some instances I have gathered from the aforesaid trees, 'not five or' six beantiful pears, only, but from one bushel to one barrel per tree. I do further aver, that these trees were originally ripon the quince stock-that some of them remain in that condition now, but that most of them have rooted from the pear stock.

"That there may be no misunderstanding of terms, let it be remembered, that when I speak of dwaif pear trees, a term which I did not use in the quotation eited, it is in contradistinction to those which are on the pear root; for we of Massachusetts do not allow pear trees, aren those on the Quninee, to remain

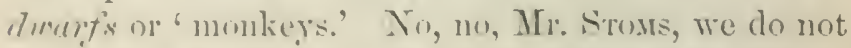
only make our pear trees arm, wen on the Quince, into beantiful, lange pyranids, lut we make them

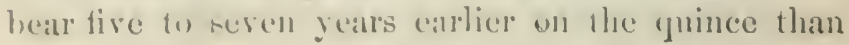
they would on the peene stock. And, as to planting 
deeply, so as to allow the pear stock to root, it is no 'new thing with the intelligent Colonel,' for he has always praeticed this system-a fact well known to his Ohio friends, and to every one who has visited his grounds.

"M[r. Stoss asks: "Why graft on the quince stock at all?'

"Answer: To obtain 'early fruiting,' and the pleasure and profit of regular crops, for many years, before the trees would produce fruit on their own stock.

"Again, he inquires: "Will the Pear, under the circumstances he (Mr. WILDER) describes, (that is, rooting from the pear stock) continue to be a dwarf?

"Answer: No; nor do we desire that it shonld; for, having eommeneed fruiting and furnished itself with fruit-spurs, it will continue to bear, whether on the pear' ol' quince root, or on both; and, as to 'longevity,' it is generally admitted that the more roots a tree has, the greater will be its strength, and the longer its duration of life.

"Hence we plant the tree deep enough to allow it to root from the pear stock, and thus we kept the quince stock soft and emollient, also, eausing it to swell evenly with the pear, and to emit roots throughout its stem, which it will do, if kept below the surface of the soil.

"M[r. Sross further says: "When the friends of dwarf pear tree culture shall come forwarl, and, with 'bill of particulars,' show me an orehard of five hundred dwarf pear trees, that have been ten years 
planted, which have borne fruit successfully and paid cost, I will give up the eontest.'

"I will then take him to my neighbor, Alstrx's, the 'Treasurer of the Massachusetts Iforticultural Society, who has five hundred and ten pear trecs. All these are on the quince root, with the exeeption of one or two dozen, which are on the pear root; but as these latter lare borne but little fruit, Mr. S. will not object to their being counted in the lot. These trees are from eleven to thirtecn years of age. One hundred of them are Louise Bonne de Jerseys. These trees commeneed about three years after planting, have borne regular and abundant crops erer since, and are now in a very vigrorons and healthy condition. No account of the crops were kept until the year 1Es1, but Mr. Arsmx lats lindly furnished ne with the amount of his sales since that date. The total Eales, for six ycars, were $\$ 3,408.76$. The original cost of these trees was about fifty cents each, or $\$ 250$. Mr. Arsm is a merchant, and goes to the city every day, and the only help he has had, is the service of a man who talkes care of his stables and grounds. IIe hats, however, given them his personal attention, and good cultivation: but, I think, without further estimation of ' cust,' we may reasonably conclude that these 'five hundred tices' have 'borne successfully, and parl cost.'

"We will then take al ride over to the Messrs. II crex, where we shall find a much larger number of pear trees on the quinar rout. 'Their beantiful avenues are lined with them, some of which are from tifteen to twenty years of age; but as it will oecupy, perhaps, 
too much time to examine all of them, we will take one walk as an example. How delighted Mr. S. must be to see 220 pear trees, 110 on each side, loaded with their luscions fruit, only eight or nine years planted, and all independently on the quince root. The prodnct of those trees, in 1S55, was twenty barrels-in 1856 , twenty-five barrels. The highest price obtained was twenty dollars per barrel, the lowest eight dollars. Then we can call on Mrr. Stickser, and look at his 'dwarf' pear trees. We shall see some magnificent specimens of Urbanistes and Louise Bonne de Jerseys. The crop of the latter he sold the last season at ten dollars per bushel. Then we will go to Mr. MLAwNING's, who las some pear trees on the Quince of rery large size, being from thirty to forty years old, and which 'still live,' and produce amnual crops. Then we will pursue our jommey on, and call on $2[r$. C.Msor, the P'resident of the Massachmetts Horticultural

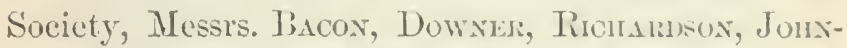
sos, and other's, who have splendid collections of 'dwarf' pear trees which have been 'plantid ten yeurs." "

Mr. R. Bust, of Philadelphia, one of the most candid and reliable men, lias published the following on

DWAIF PJELIS.

"This term has led to the iniression that all trees are dwarts that are grafted on the quince stock: we do not incline to this term, from the firct that we cultivated dwart pears before we knew of the effects of the Pear on the Quinee, and also from the fact that we now have very the stenderd trees, with stems six and 
scren fect clear, that are on the quince stock. Tho Pear, Apple, Quince, II awthorn, and Mountain Ash, all belongr to the same class and orcler, and will grow if gratited on each otlier; they do not all, howerer, assimilate well with each other, for we tind that there are some Apples that will not grow on the Pear, and vice rerea; there are also Pears, and not a few, that will not srow on the Quince; others that grow well, but their fruits are inferior; whilst again many arc greatly improved on the Quinee. Tre now say that the Pear, to be succesful on the quince stock, must he very highly cultirated with enriching manures of almost any description, incorporated with the surfince-soil, and fiequently stirred during the growing season, repeating the en riching material, and thorough culture, crery season. They can be planted from ten to tifteen ficet apart, and will, with such treatment, give a very abundant crop, even a bushel from a tree only a few years planted. This is not, howerer, the only attention they require-they must have a summer pruning and a winter pruning, which you shall have in another cliajpter.

Again, the quince stock is a very general tem; there is a rast difference in the linul of Quinee, and it is now very strange that all the pears on the Quince, whether worked thereon the past year or ten years, are on what has recently been called to the jeculiar bencefit of some, the Angers Qunece. Certain it is, that there is a vallety alptly aldipted to the vigur of the Pear, more enencrally known to the experienecd cye hy its growh as that valiety: and we think it is the variety only that demands particulan notice. Tho 
growth is clean and luxuriant, bark smooth and free, making shoots six feet high in a season, readily propagated from cuttings, and even budded the first season.

Every cutting, therefore, of that variety, should be carefully planted, on which yon may grow either dwarf or standards, with this result that the sorts of Pear worked thereon will come into bearing in two or three years, and continue productive for many jears, say half a century, and be more free from blight than if on the pear stock, which roots deep, descends into the cold ground perpendicularly, predisposes the tree to blight during summer, and if not blight, pro duces a redundancy of wood almost beyond practical management, and not at all adapted for gardens. Another point in favor of the quince stock I might refer to, is the certainty of its growth after being removed and conreyed to a distance, the many fibres close to the bole of the tree rendering its growth almost certain, at least, forty-nine out of fifty. The Pear on its own stock makes few fibres, and is more precarions in removal and carriage; this is again partially "under control by frequent removals in the nursery, when the trees are young, which checks their growth of wood, prodnces early fruiting properties, so that we hope to tive to see dwarf fiuiting pears on the pear stock as eagerly sought for as those now on the Angers Qnince-yon will please make a note of this assertion."

The following from Mr. IIover, anthor of "Fruits of America," will be of interest to pomologists: "The cultivation of the Pear on the Quince is of such 
an ancient date, and has been so longr and so suc. cessfully practiced in that great pear-growing country, France, that it appears somewhat absurd to see it attacked at this late day, as it has been by individuals who, either from want of experience or otler causes, lave not succecled well in its cultiration on this stock, and hence wonld deny to a great portion of om commmity, for a series of years, so delicious a finit as the Pear; for in no way can it be obtained in any abmudance, for halt a generation after planting, except upon the Qnince.

An intelligent correspondent has shown the fallacy of the arguments made use of to disparage the quince stock, and it would be useless to go over the ground again. As lie has truly said : " Let gentlemen botanists have their own way in disputing. On we shall go, reaping an abundance of fruit while they are cavilling in regard to a fact long ago established by the experience of men, not mere tyros in the work, but those who have made the question a study for life."

RELES FOR GROWING THE PEAR ON THE QUINCE.

From these just and lueid statements of distin guished horticulturists, it is easy to learn that the requisites fol successfully cultivating the Pear on the Ruince are:

1. That the pear shonld be budled on the Angers Quince, a fiece-growing valiety-a tree rather than a Elrmb), like the Portugal (guince. Sereral specincus of this varicty, on my gromuds, have grown, in two Ecasons, seren feet in leigrht, and one inch and a yuarter in diameter. 
2. That only the right kinds of Pear should be grown on the Quince.

3. That the Quince should be considered in this compound tree, only as a root, and nerer as a trunk or stem; and, therefore, should be planted entirely below the soil.

4. That the tree should be trained low, in the pyramid shape.

5. That weeds and grass, and, of course, the grains, must not be permitted to grow among the treesas they wonld interfere with the development of the lower limbs, and abstract the nourishment that shonld go to the tree.

6. That the soil should be kept in good condition, well manured, well eultivated, and dry.

The violation of these rules lias, without doubt, been the cause of all the failures of the Pear on the Quince.

ROOTING OF TIIE P'EAR ON QUINCE STOCKS.

It is very difficult to induce the Pear to form roots from cuttings or layers, nuder the ordinary circumstances attending such propagation. Most varicties of the Pear, howerer, when budded on the Qnince, and planted with the junction from two to four inches below the surface, exhibit a great tendency to throw ont roots from the pear wood above the junction.

Mr. WiLdis, and some other horticulturists, believe this to indicate a natural repugnance in those rarietics to the Quince; but my own experience docs not confirm this. Of a considerable number of Bartlutts remored after being three years planted in the fruit-ground, 
not more tham half a dozen liad rooted, and theso very feebly; while it is well known that this variety suceceds only indiflerently upon the Quince. Other fircts, howerer, (l) tend to confirm this theory. I hare seldom found the Duchesse exhibiting any tendency to throw out roots. While of several hundred of other varietice, five or six years old, removed at the simne time witl tlie Bartletts above-nentioned, more than half liad looted from the penr wood, and the character of the roots was somewhat striking. When a wild or seedling pear is budeled and planted in the fruit gromels, its tendeney to form long, stragghling roots, almost destitute of fibres, unless root-pruned or retrin:jlanted, is well-known; but erery one of the Jonts finm the pear wood abore the quince stock of thees trees, was provided with such masses of fibres, that it was nearly impussible to fiee them from the adlering soil. Tiemarkible as is this faculty of fibrous rooting of the Quince, it is much more surprising in the Pear, when grown on the yuince stock. Many loots, thece or four leet long will be found, fringed witlı fibres throughout their entire lengrth, and in such maszes ats to remlel it necessary to grewatly thin them, when reset in the gromul, to allow them to be separaterl ly panticles of soil. In some cases, I have fomm the quince root entirely superseded and cast ofl. In

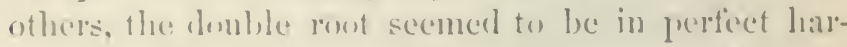

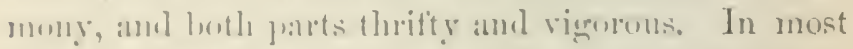
ciscos the prear root hall heen formed on one side of the eree, and ripidly radiating and swelling at the junction, had usurped the entire irromed, and lield tho tree timly and strougly in the soil. To test the fact 
of the rooting of the Pear above the Qnince, it is only necessary to scize the tree by the body three or four feet above the gromd, and shake it slowly, and if pear-rooted, the superior firmness will be readily perceived. The wood-growth and foliagre of all trees, throwing ont roots above the quince stock, will be found to be more vigorons, but the production of frnit will be considerably delayed. If a strong, vigorous shoot or sucker grows up from near the ground, or if the branches are much more strongly developed on one side, it is quite certain that the Pear has rooted. I am often asked, if the tree roots from the Pear, what advantage is gained by growing upon the Qnince?

This query may be answered by a statement of the following facts :

First. Many of the varieties budded on the Qninee do not obtain pear roots sufficient to support the tree before the sixth or eighth year, and the trees, in the mean time, have borne fruit three or four years, while if budded on the pear stock, few of them would have yielded finit in less than eight or twelve years.

Second. The greater vitality of the Qunince root has preserved life in a large per-centage of the trees, which, under ordinary care, wonld have perished if budded on pear roots. The ratio of loss l,y transplanting healthy trees on quince roots, with but moderate care, is not more than one per cent, while that of pear trees on pear roots, is mneh greater. After the pear roots form above the Quinee, the tree is (from causes which will be hereafter investimated) so much better furnished with fibres, that it will enduro 
transplanting and root pruning better, and also continne much longer its growth and fruiting.

Third. The quince root has so governed the growth of the tree, that it is much less difheult to reduce it to pyrunidal shape; for it has been proved by experience, that the character of the roots determines that of the top. Long, stragrgling roots, not provided with fibres, are productive of long, vigorous, and unmanageable shoots, destitute of lateral branches. $\Lambda$ loug tap-root sends up a vigorous lealer, while the fibrous quince roots provide the tree with fruit-spurs and short, stont branches. 'The Pear on a par stock is not easily redueed to a pyramidal shape after the first year, without root pruning, for when the leader is pruned, the terminal bud shoots with great vigor, and amother leader is formed while the lower branches contimue weak and feeble.

Fourth. Most of the varieties which are superior in size and flavor on the Quince, or which unite firmly with it, and prove well adapted to it, as the Duchesse d'Angonlêne and Louiso Bonne de Jersoy, soldom throw ont roots from the pear wood. In those varicties which throw ont pear roots, it has been scen that the latter are more fibrous than upon seedlings. 'This is, doubtless, the result of the nore refined and enltivated condition of the grat:ed wood, which, instead of the rank chatracteristic of a seenling, makes the clean, stocky shonts of a more highly ilevelnped tree. So the finer varieties of pears, insteal of the long naked ronts of the wildling, provide themselres with filwous radicles better fitted to furnish them their proper food. 
This fact has tended to confirm horticulturists in the belief in the necesity of an adaptation of the graft to the stock. If this theory is correct, what roots can be better adapted to the demands of the graft than those put forth by the graft itself. From these facts, it may be seen that if any pear-grower is deficient in faith in the durability of quince stocks, he can insure the longevity of his trees by planting them sufficiently deep to produce pear roots.

HOW TO PRODUCE PEAR ROOTING.

When the leaves ripen in early September, the sap has assumed that albuminous and ripened condition which fits it for forming new spongioles and rootlets. If, prior to this condition, several incisions are made in the pear bark and wood, just at the swelling of the graft, by pushing a small gonge upwards, so as to form tongues or strips an inch long, hanging by their upper ends; the sap, checked in its downward flow, will soon corer the incision with a soft, white, albmminous substance, which, if well covered with fimly packed earth, will soon form rootlets, that, before the ensuing winter, will be in a vigorous condition. It is well to place a small pebble between the tongue and trunk to prevent adhesion. The production of these roots is due to the same influence which canses the union of the bud with the stock when inserted at the same season. The sap, in its downward flow, depositing the mucus that would have laardened into bark and wood, is, by the check, diverted to the formation of rootlets and tibres which will, the next year, provide food for growth or fruit. 
It does not seem to have been considered by horticulturists, that the absorbing power's are not retained by spongioles and rootlets much longer than a single season, and that they need constant renewal. When the hardening of these spongioles takes place, they are no longer capable of affording a supply of nutriment proportionate to the wants of the tree. Most tree enlturists will have noticer that the fibres and Epongioles are not found on the larger and older roots, but that, having fulfilled their office, they decay, as Niture never supports useless organs.

What will be the effect of pear-rooting upon those raricties that are so much superior upon the Quince, must be determined by more experience than wo possess at present. There is but little doubt, however, that the pear-rooting of such varieties as are gritty or astringent on pear stocks is to be aroided.

The Duchesse d'Angoulêne, which is not often firstrate on pear roots, because of its hard lumpy flesl and gritty core, and the Louise Bonne de Jersey and Beurré Diel, which are often astringent and bitter, on the same stock, can hardly be allowed to root from the pear wood. This may be prevented when necessary, by planting more shallow, leaving the pear-wood but little below the surface.

DOUBLT; WOIKING.

It is often desirable to improve the textnre and flavor of some varieties of pears, by growing them upon the Quince, although they have proved madipted to it. The desired eflect is obtained by donble working-as it is the roots, the providers of nourishment, 
that govern to a great extent these characteristics in the fruit. Any frec-growing varieties may be budded on the Quince, for the purpose of double working, al though some care should be taken to obtain such as harmonize with the Quince. The Virgalieu and the Buffam are the best, although not the most vigorous growers; yet most pears grow well, when propagated upon them.

The Beurré d'Amalis and Soldat Laboureur, are very vigorous growers, and make good stocks for double working. There are such obvious advantages in double working, that it scems almost superfluous to mention them, yet that nothing may be omitted to secure success, we present them in a concise form:

1. Pears that refuse to grow, or grow but feebly, or are short-lived upon the Quince, but are coarse, gritty, or small sized, when grown upon the pear stock, like the Beurré d'Aremberg, often become firstrate by donble working.

2. Varieties that are so tardy in bearing upon the pear stock as to exhaust the patience and faith of the grower, yet will not harmonize directly with the Quince, will, by double working, come early into bearing. The Dix and Seckel are examples of this.

3. Grafting, which cannot be practiced with success directly on the Quince, may be performed on the Pear portion of the stock.

4. Some varietics that bear quite early on the pear stock, but are of comparatively slow growth, are preduced in greater vigor upon the donble stock, in consequence of the increased vigor acquired from the strong growing variety first worked upon the Quince. 


\section{FARIETIES FOR DOUBLE WORKLTG.}

The following varictics, which have prored arcrse to the Quinee, will, by double working, bear fruit improved in texture, size, and flavor:

Bucuré d'Aremberg-coarse, woody, and gritty, on pear roots, and a feeble, diseased grower, directly on the Quince.

Trapoleon-often scarred and spotted on the Pear, but frequently handsome and smooth upon a donbleworked tree.

Bartlett-although fine when grown on the pear stock, is much improved on the Quince.

Beurré Clairgeau-coarse on pear roots, somewhat arerse to the Quince, but nearly first-rate upon doubleworked trees.

The following varieties, that are tardy in bearing, are but moderately improved by the Quince in quality, and are propagated with diftienlty upon that stock, but may be profitably grown by double working:

Beurré Bose, Dix, Seckel, Tyson, Andrews, Fulton, Lawrence, Winter Nelis, Marie Louise, Beurré Rauce, St. Michael Archange, Columbia. 


\section{PART V.-PRUNLNG.}

ADFANTAGES OF A PFRAJIDAL FORJI FOR PEAR TREES, BOTH ON QUINCE AND PEAR STOCKS.

THE advantages which seem to be gained by a pyramidal growth in the pear tree, more especially, are:

1. There is no violent interference with the natural structure of the tree, but we rather aid it to attain this form more perfectly; that is, we do not by crowding it in the nursery rows, or by cutting with the pruning-knife, deprive it of the natural formation of low branches. To cnt any portion of the rood, of more than one year old, is to interfere more or less seriously with the organism of the tree; and the occasion for it arises from neglect to prune at the proper time. To prevent malformation is better than to amputate; and to form a tree properly, we must begin with the maiden plant.

2. Low-branched pyramids come into bearing much sooner than trees witl long trunks. The Pear, on its own stock, trained as a standard, varies with the lind, from cight to twenty years, in prodncing fruit; hut, trained as a pyramid, its period of fruit-bearing is lessened from four to twelve jears. The Seckel and 
Urbaniste, npon pear stock, and whth naked trunks, of five or six fect, are not unfiequently fifteen years producing their first fruit. With low-trained pyramids, and a slight attention to summer pruning or pinching, this tedious and discouraging delay is most certainly shortened to six or eight year's. The cause of this precocity is, that the sap, checked by the sum. mer pinching in its flow to the terminal bud, is dis tributed to the wood-buds below, and sufficient nutri ment is received to mature them into fruit-buds.

$A$ certain age of bark and cellular woody formation of a branch is necessary before it will cause the sap to flow slowly enough to concentrate into fruit-juice. Now, if the earlier branches, formed near the ground, and then, in succession, those abore, are cut away, until a naked trunk is formed, it is evident we protract the fruit-bearing period. Besides, the pruning awry of so much wood forces an over-abundance of Eap to the terminal buds, and its energies are spent in wood-growth, at the expense of fruit-bud formation. When, howerer, branches start from or near the ground, having the same age with the trunk, fruitbuds are formed long before they could have been on long-trunk trees; the sap is more erenly distributed. wood-growth is moderately checked, and the cultivator's eye is early gladdened with golden fruit.

3. The size and quality of fruit is much increased by this metlod of training. It has long been known, that young trees prodnce larger firuit, but deticient in flawor; old trees produce fruit of superior taste, but inferior in size. In the pyramid, we are able to secure these excellences, and rid ourselves of the faults. In 
the low, compact form, when an execssive quantity of fruit has set, it becomes an easy task to thin out the overplus, and concentrate the sap in that number which can be perfectly matured.

4. A much larger number can be planted on a giren area. Instead of forty pear trees, planted at forty fect apart, two hundred to four lundred inay, for many years, occupy the same area, and yield their fruit to a whole generation without crowding. It is much easier to cut down a fruit tree that cost a few shillings, than it is to obtain it with fifteen year's' additional growth for ten dollars. Many a man would hesitate to plant ten acres with four linndred pear trees, even when by pyramidal growth he could obtain a bushel from each, at six to eight ycars of age, who would gladly cover one acre with the same number, could he be assured that they would fruit egually well. 5. Pyramidal trees, by their comparatively low stature, are protected from highl winds, and often preserve their fruit when the tall tree lias lost a large portion of the crop: their limbs are much less exposed to being broken by storms, or borne down by weight of fruit-whose power is much increased by growing at the end of a long branch, which acts as a lever.

6. Pyramidal trees are less liable to wrenching from the perpendicular, turning over by the roots, or breaking off: having their widest diameter at or near the ground, they offer little resistance to the wind; and never exhibit the distorted, leaning attitudes that characterize thousands of orchards.

7. The trunk is protected by the foliage from the 
parehing sun-rays, and the sap reaches its destination just in the condition Nature provided it in the roots, without travelling an unnecessary distance.

\section{PRUNING TO FORAI PYRAJIDS.}

It is with considerable difficulty that trees in tho usual condition in which they are received from the mursery are reduced to a pyramidal form, branching from near the ground. If two years old from the bud,

Fig. 33.

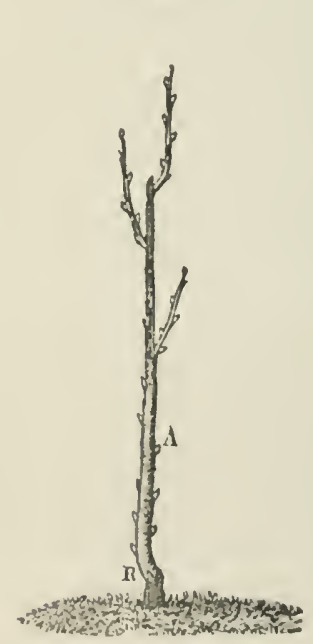

FIg. 84.

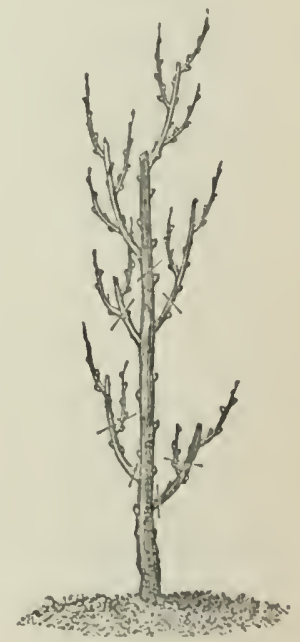

and lateral branches should have formed, the ruthless knife of the murseryman has pruned them away. Figs. 38 and $8 t$ are specinens of trees where some fecble attempts liave been made for the production of a pyramid. The lower cross lines in Fig. 34 indicate the vicious pruning such a tree would usually 
receive. The other lines show the points at which the limbs and trunk should be shortened.

Haring shortened the tree shown in Fig. 33, at A, the next effort of Nature is to effect an aeration of the sap produced in the roots, and as there are but few buds to expand into leares, a large amount of sap is thrown upon these few.

The difficulties in forming pyramids from such trees are numerous. Unless the tree has been rootpruned, or recently transplanted, an effect of this severe shortening, called by horticulturists suffocation, ensues, and a sickly growth of small shoots is the result. Not unfrequently, several shoots start from near the amputation in a bushy cluster, or a gourmand or two obstinately shoots up, absorbing all the sap. It will now become more and more difficult to draw ont the buds below, and, after the bark is two years old, almost impossible.

Under this treatment, we must thus commence our pyramid with a raw amputation, that will exhibit for years an ungainly scar, but there is nothing less severe to be done until we have better-formed nursery trees, and can remedy some of these evils, by commeneing the process in the first season, as shown at Fig. 35 , which has been already explained on page 99.

If the tree shown at Fig. 33 is planted in the same season of its shortening, but little growth, of conrse, will be produeed during the first year, but if perfectly successful in aroiding all the mishaps noted, it will, at the end of the second year, exhibit somewhat the appearance of Fig. 36. If more shoots should have been produced than neecssary, they must bo 
thinned so as to leave the remaining ones well baianced around the stem. Select one for a leader, that

Fig. 85.

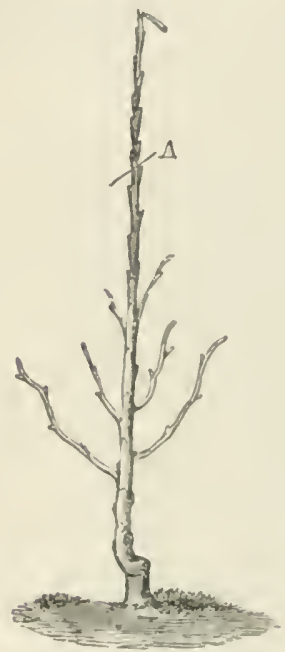

Fig. 86.

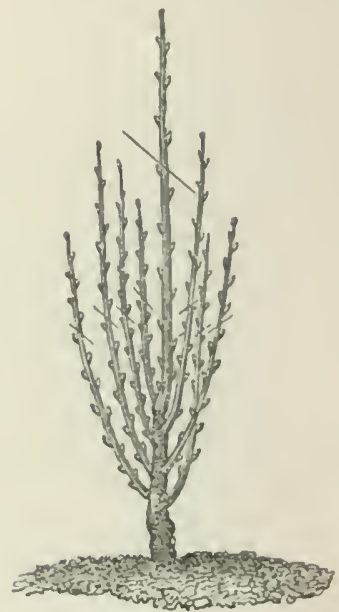

as nearly as possible oceupies the centre of the group, and starts near the top. All the shoots oughlit now to be shortened in such a mimner as to induce a cone shape to the tree. 'To eflect this, the lower ones should be cut back to six or eight inclies, the next reduced two inches more, and the next still more, until, as we approach the leader, the side shoots must be shortened to two or three buds. From this time, with proper attention to summer pinching, pruning might be alunost entirely dispensed with; lut as few jersons will ol can bestow the requisite labur, we thall still adapt the instruetions to the ordinary condition of trees. 
By attention to former suggestions, the tree, at the end of the third summer, may be expected to appear as in Fig. 37, and from this time, the progress of the tree in growth and shape is much more rapid. The trees exhibited at Figs. 37 and 38 are often exceeded in size by such as have been planted a year less, but they are much oftener not equalled in this respect by trees planted four or five years.

Fig. 37.

Fig. 83.
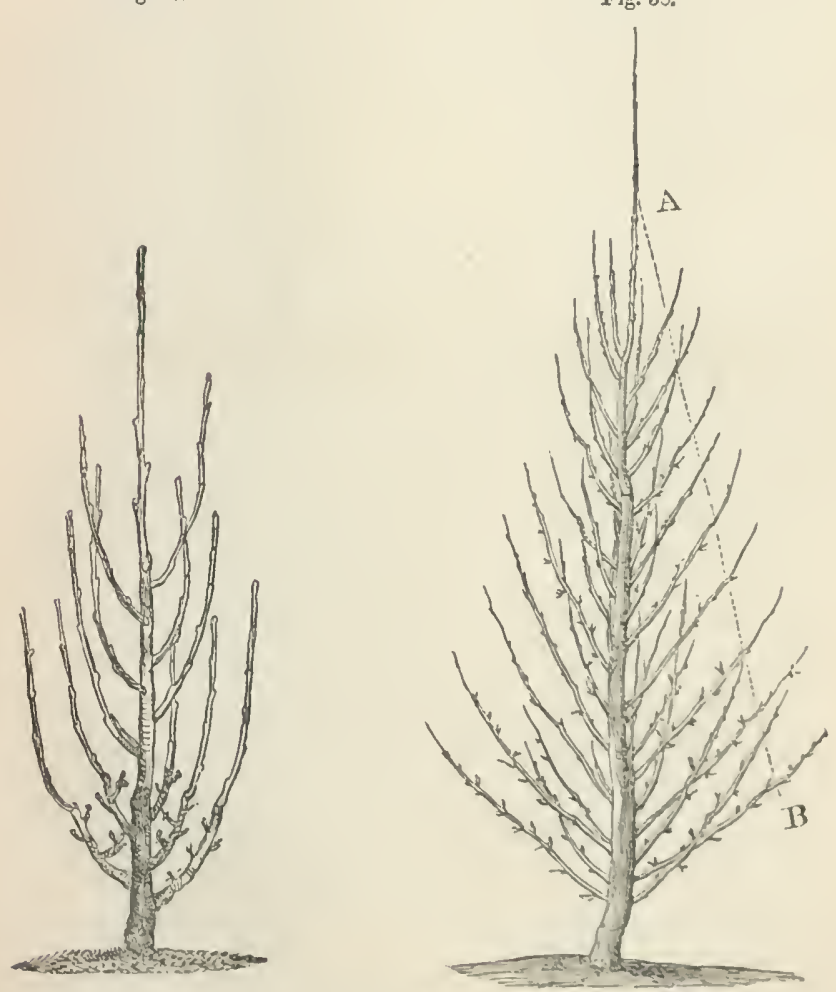
When the pyramidal shape has become establislied, as in Fig. 3S, the pruning is pertormed more directly with the intention of inducing the formation of firuit-buds, but the preservation of the shape must still be kept in vicw. The line AB in Figure 35 indicates the place at which the branches should be shortened.

Fig. 39 is a wellbalanced pyramidal Urbaniste, ten or twelve years old. The characteristic growth of this varicty may be observed in its too numerous branches. It cannot, lowever, be thinned to the extent necderl by other varicties witlont delaying its fruiting, on account of its great tendency to woud-growtl.

Fig. 39.

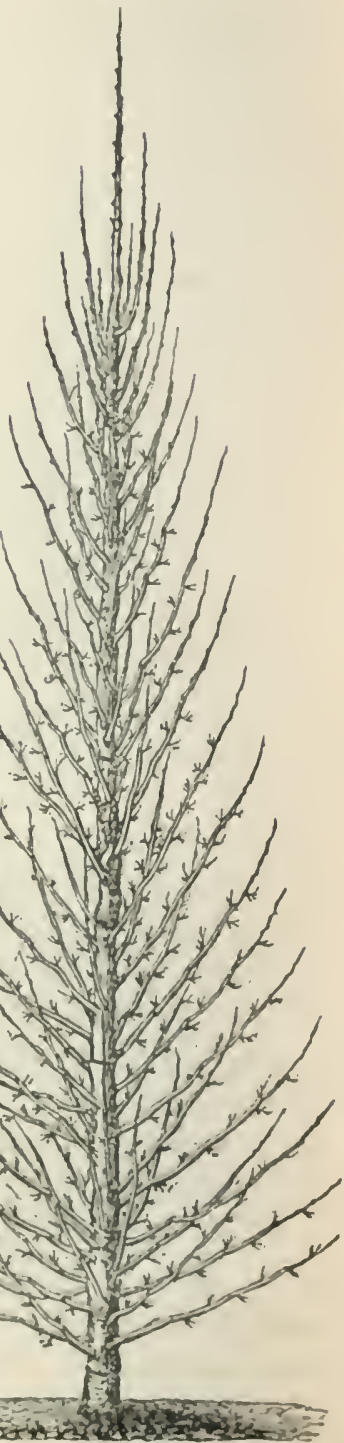


Although the pyramidal form has become estab lished, this tree would soon grow out of balance if neglected. It will require annual pinching and summer checking of the leading shoots not only for the purpose of restraining them, but to preserve the development of the lower branches.

From neglect or bad pruning, it is not unfrequent that trees aequire a growth similar to Fig. 40, which is a portrait of a tree in my own grounds. In its first pruning, the stem was left too high, and, in consequence, a long space has occurred at $A$ and $\mathrm{B}$, freo from radial branches. After some subsequent pruning, a gourmand, indicated by $\mathrm{C}$, has pushed out from near the collar.

Another error in pruning is shown at D, where a cut was made too far above the bud, or the branch. The highest shoot in this tree has abdicated the leadership, and a strong rival has pushed up from below it. Some of the methods of remedying the numerous evils in the condition of this tree, without shortening it back so severely as to lose three or four years in its fruiting, will be noticed. To cover the naked space on the stem, the shoots $\Lambda$ and B, Fig. 40, may be ingrafted by cutting them to a wedge shape, at $A$ and $B$, and fitting them into a notch in the stem, made with a chisel, or by removing small sections of bark from both the stem and the shoot, and binding the two firmly in contact. The gourmand may be used for ingrafting upon the trunk, at $G$, but when not used as a graft, it should be cut at $F$, in order to conceal the trunk with foliage. The branch and part of the steni, at $\mathrm{D}$, should be entirely removed, in order 
to allow $\mathrm{E}$ to become the leader. All the branches should be shortened, the upper to three or four inches, and the lower to six or eight, and the leader to ten or twelre. Fig. 41 , represents, at $\Lambda$ and $\mathrm{B}$, the incisions which are made above a weak bud, or shoot, to check

Fig. 40.

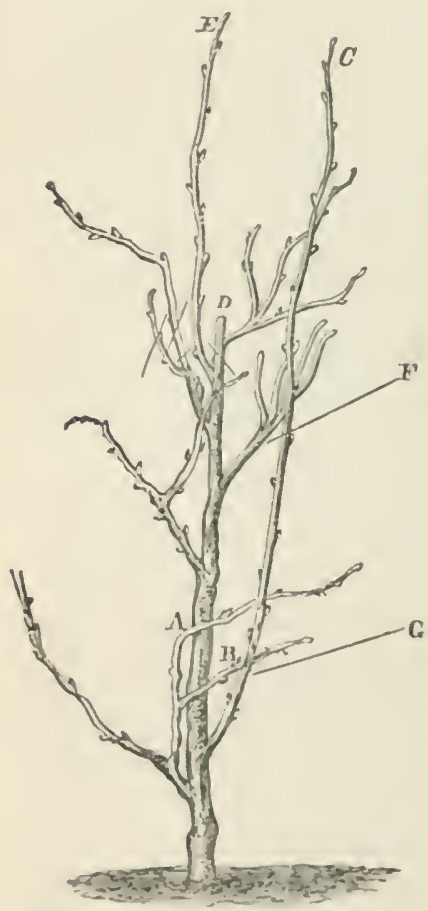

Fig. 41.

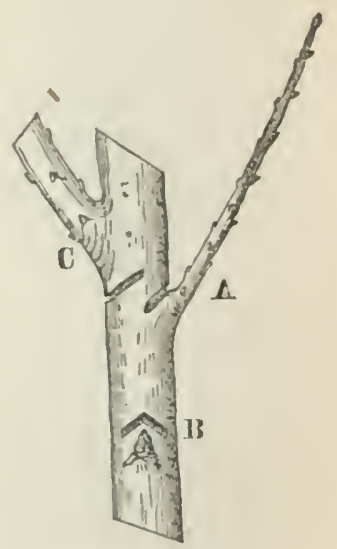

the flow of sap, and force it to their development, $\mathrm{C}$ is the incision made below a strong shoot to check its growth.

It is important in pruning, to cut so near a bud that 
the wound will be within the influence of the sap, elaborated by the leaves formed from that bud. If cut as in Fig. 42, the wood above the bud being beyond the flow of sap, usually dies, and produces a bad effect. The ent in Fig. 48 is made so low as to endanger the life of the bud, and effect the same bad result, as in cutting too high. The true rule for cutting a bud is, to make the slope reach no lower than the bottom of the bud, and high enough on the side of the shoot nearest the bud to clear the top of the latter. Fig 44 represents the true cut.

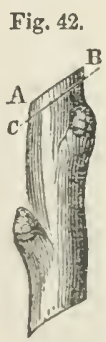

Fig. 43.

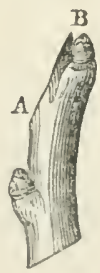

Fig. 44.

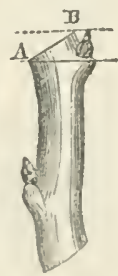

An irregular form of trees growing on quince roots, and resulting from overfruiting, is exhibited by Fig. 45. The check to wood-growth, caused by the early fruitfulness of the tree, resulted in the change of most of the buds to fruit-buds. When a period of rest from fruiting occurred, and the tree had acquired strength for further growth, this was all produced at the top of the tree, and thus its balance destroyed. To remedy this, the tree may be either shortened at the point indicated by the long lines, or the limbs pruned at the small cross lines, and the lower part kept from fruiting for a year or two. Combined with summer 
pinching of the ty slioots, this last method will restore the shape without losing the growth of two or three years.

I am often pained at being obliged to cut away half a dozen luxuriant shoots, tlree to fire feet in length, the growth of the preceding summer, upon a tree, which, by their production, was thrown entirely ont of balance. But most twoyear-old trees, if previonsly neglected, prove too obstinate in their acquired habit of growth, to form easily into pyramidal shape. 'The bark lias become ton old for hnds to break from, without cutting so low down that one may almost as well begin with budding the stock, thus groFig. 45.

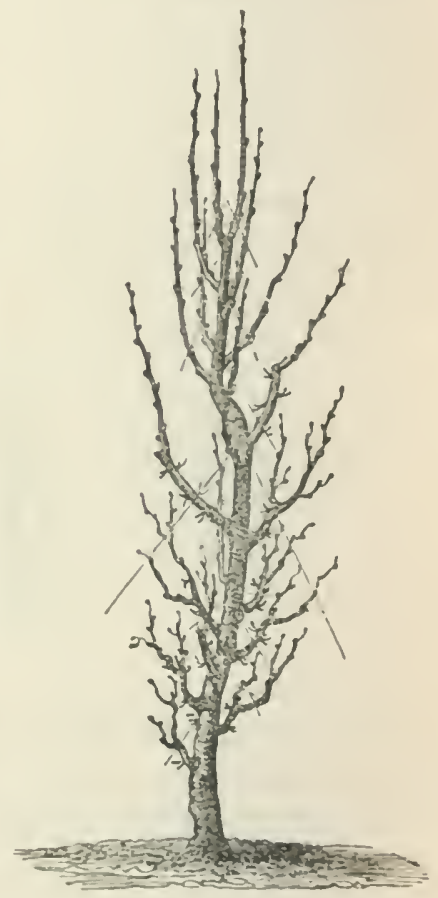
ing back to the rery fomdation of nureery treatment.

As the fruit-raiser may save several years' labor and delay by eclecting large trees, it will be seen that it is of comsirleralile importance to obtain thoso that lave received funper cille in the proper time. When well-shaped trees, two to four years old, camnot be procmed, it is better to select maiden 
plants, or those of a single season's growth, as shown in Fig. 29.

\section{SUMAIER PINCHING.}

This process consists in checking the growing shoot during summer, either by the thumb and finger or the knife. Sometimes the soft terminal tuft of leaves is pinched entirely off, sometimes a considerable portion of the shoot is cut away, and occasionally they are simply fractured, and left hanging.

'This labor may be performed from the first breaking of the bud to the middle of July, the time for its performance being governed by the need for shaping the tree.

As before stated, the perfect formation of a pyramid is commenced in the nursery. The plant budded the previous year should stand at sufficient distance from its fellows to allow its branches to radiate from the grnund, for a foot on either side, without interference from them. Near the middle of July, the terminal bud should be pinched off' as at Fig. 35. The wood, now in its sneculent condition, heals over at once, and no scar remains.

By the loss of the terminal bud, the sap is distributed to the lower buds, and if, as usually occurs, radial shoots do not push out, the former are strengthened sufficiently to form strong shoots during the next season. The tree, if well grown, is, at the end of the first season, fully equal, for forming a pyramid, to the one exhibited at Fig. 36 . B5 a regular system of summer pinching to restrain undue rigor of some of the shoots, no great interference with its organism need occur to preserve the pyramidal shape through 
all its future growtl. I have often secn a difference of two year's' growth in favor of summer-treated trees over those whose pruning was delayed until the wood ripened.

To induce the formation of fruit-buds, summer pinching is successfully resorted to. Fig. 46 cxhibits a twig with wood-buds at $A$ and $B$, and the soft summer growth beyond. If in July this is pinched off' or only broken to remain hanging, as in Fig. 47 , the small weak buds at $\Lambda \mathrm{B}$ will be strongly dereioped, and appear as in this last-mentioned Figure. $\Lambda$ the swelling of the buds in the next spring, these will appear as shown in Fig. 4S. In all these Firgures, the shoot is represented as broken too closely to the buds.

Fig. 46.

F $48,47$.
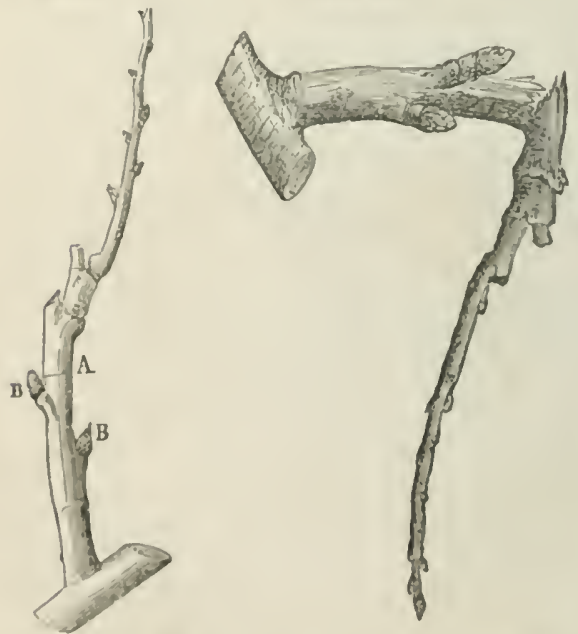

Fig. 4 .

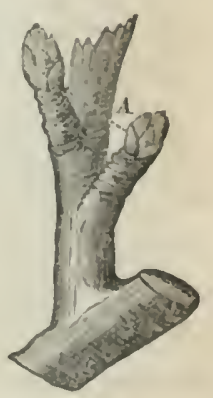

Summer pruniug must not, how a er, be continued 
so late in the season as to induce an unripened growtl. When several small shoots have formed from the upper buds after pincling, they should be removed in the subsequent spring, as they would tend to form a tuft of branches on the end of the shoot.

The treatment of fruit-spurs upon bearing trees forms no unimportant part of their management. The excreseence remaining at the base of the stem of a fruit of the Duchesse d'Angoulême is shown at Fig. 49. When this is cut at $A$, the small buds appearing at the base are developed in another year into the condition represented by Fig. 50. These fruit-spurs will now, if not displaced or crushed in gathering the fruit, become permanent, and afford a security for fruitfulness in the tree. Fig. 51 exhibits a elnster of fruitbuds on a spur, that has borne several times.

Fig. 49.

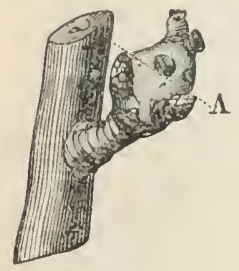

Fig. 50.

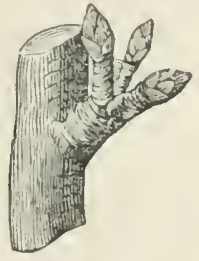

Fig. 51.

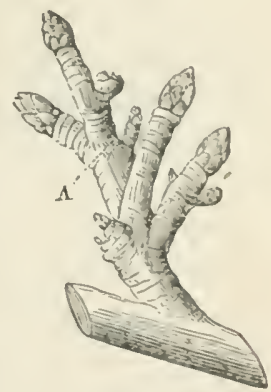

The rules for summer pruning and pinching may be condensed as follows.

1. To develop wood-buds on the lower part of the tree, prune all the branches elosely in spring, and pinch the upper shoots during smmmer. If the upper 
shoots push too strongry, deprive them partially of leaves, but allow the lower ones in the vicinity of tho weak buds to grow.

2. Allow no useless shoots to absorb the rigor and sap of the tree-for every pound of them eut atwa might lave been diverted to its proper growth.

3. To develop a weak brameh, ent it back to two or three buds in epring, provided the rest of the tree be closely pruned and summer pinched, but the weak shoot must be allowed to grow mehecked during summer.

4. To check exuberant shoots, they must not be ent back severely at the winter-pruning, but summerpincled and partially deprived of leaves.

5. Allow the strong branches to bear all their fruit, but deprive the weak parts of the tree entirely of fruit.

\section{FORJS OF TRAINING.}

Almost every variety of pear trec exhibits a distinct and characteristic growth. This inclinition to a particular form modifies our control over the tree to such an extent as to render it impossible to mold fome varieties into any of the shapes exhibited in the figmes. Other varieties acquire the pyramidal shape so rearlily as scarcely to need the restruints of pruning.

Most of the leading varieties of pear trees can be recornized by their characteristic forms aud color ot the bark, almost as readily as by their finit. The lightı yedlow bark and open growth of tice Bartlett and J)ncliesse, and the rring, densely-growing shoots of the Urbaniste, distinguish cach of them as perfectly ats the forms and colors of their fruits. 
Fig. 52 is from a photograph of a Vicar of Winkfield, four years planted, which was only pruned at the time of its removal from the nursery.

Fig. 52.

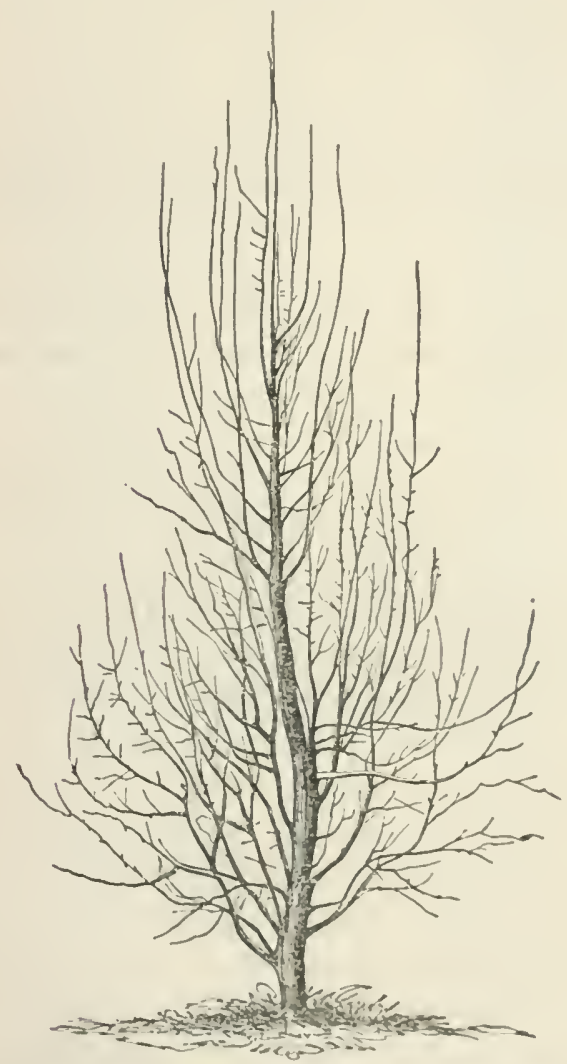

The Urbaniste and Flemish Beauty assume tho pyramidal shape without shortening, but still differ widely in their natural strueture. 
Fig. 53 represents a tree, the lower part of which has ceased to grow, in consequence of orer-fruiting. 'T'o reduce this to a pyramidal shape, withont pruning away a very considerable portion of the tree, requires judicions proning. Cut the lower, unnourished branches back to three or four inches. Leare the remainder until the next spring, when the branches extending beyond the lines in the Figure are to be cut off; but during the summer, the upper and more vigor. ons branches are to be checked by pinching, and partially depriving of leaves, in order to throw the salp into the lower ones. This is the true Quenonille.

Fig. 54 represents a pear tree trained as a column -one of those eccentric forms attempted by French gardeners, which cannot be recommended.

\section{ESPALTER AND QUENOUILLE TRANLTG.}

IIappily for fruit-growers of this comntry, they are not compelled to resort to the laborious, artificial means prateticed in other countries for the production of fruit; but as it may be desirable at some time to employ these methods for ornament or local convenience, they are here griven.

In Espalier training we should commence with the first summer's growth from the bud. The terminal bud is pinched ont in the latter part of June, and when lateral shoots push forth, they are eut ofl on two opposite sides, leaving those on the two other sides. If these push out regnlarly, two or three pair's are allowed to remain, and the stem cut back to them.

These are trained to the lattice or wall, and fistened in the fall. The next year another pair or two are 
ESPALIER AND QUENOUILLE TRAINIAC.

Flg. 58.

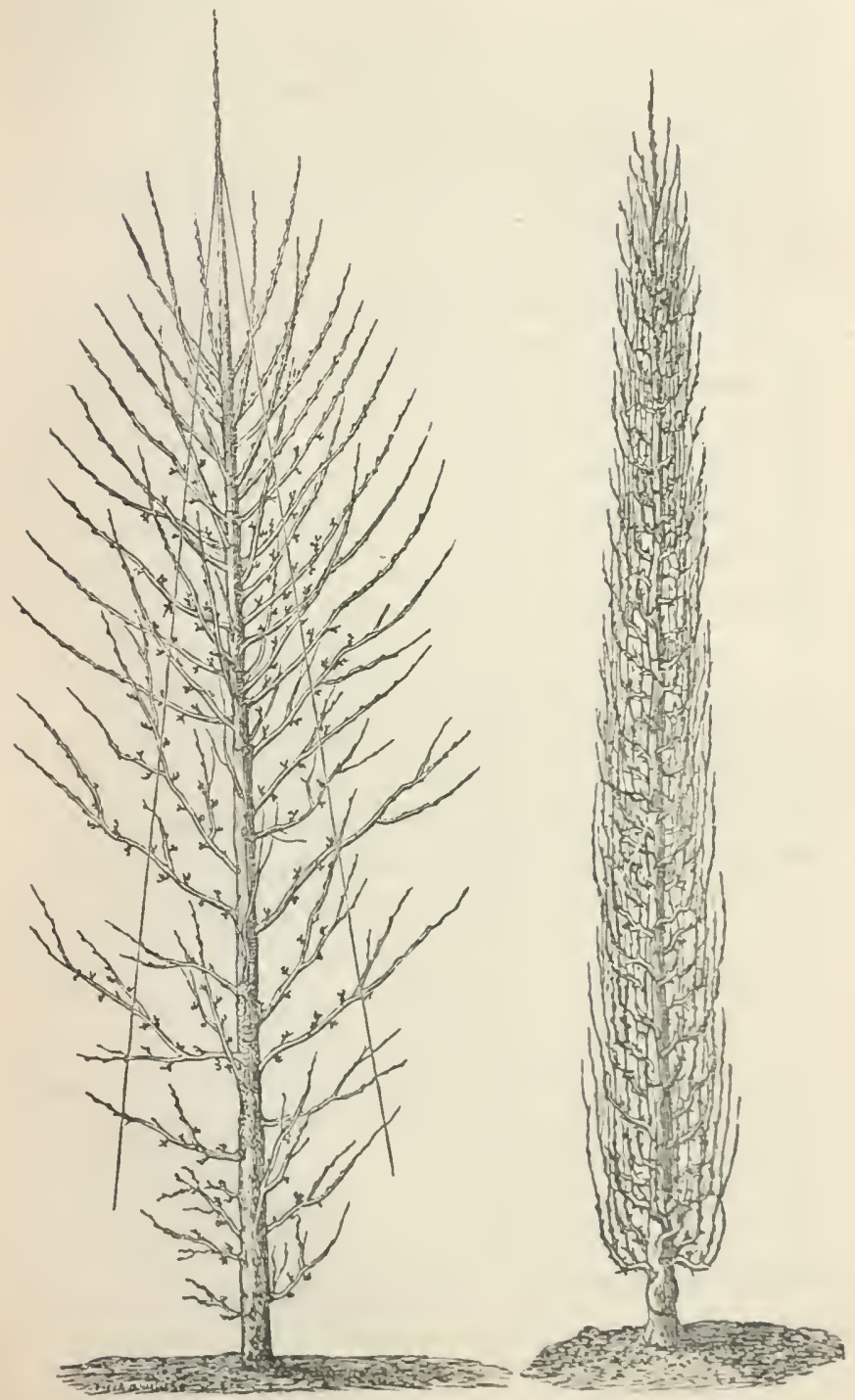

Fig. C1. 
produced at the proper distanees, and fastened as before, guarding, however, against allowing horizontal shoots to be produced more rapidly than a strong, vigorous growth will permit.

The term Quenouille is misapplied in fruit-books. It is $110 \%$ applied in France only to trees of the form represented in Fig. 53.

Arched training, as shown in Fig. 55, is nearly abandoned in France and Belgium. It is generally confessed to have produced the most ugly and illshapen trees imaginable, besides requiring immense labor and unremitting care. It consisted in tying down the ends of shoots to pegrs on the ground, nutil a drooping habit had been produced, or the check of sap by the compressure has induced fruit-bearing.

\section{RLLES FOR I'RUNING.}

1. Cut near a wood-bud when pruning to perfect the shape.

2. Prune severely in the spring those branches that are desired to grow vigornusly.

3. Pinch in summer and partially deprive of leaves those branches that grow too vigorously and absorb too much sap.

4. Thin, weakly shoots should either be pruned close, or left entire with a terminal bud: the more vigorous ones being, at the same time, stopped by pinching.

5. Let the ecverest pruning be performed on the tree when young.

6. 'To develop fruit-budis, break, pinch, or twist the shoots above the buds intended to be dercloped. 
ESPALIER AND ARCII TRAINING.

Fig. 5.5.

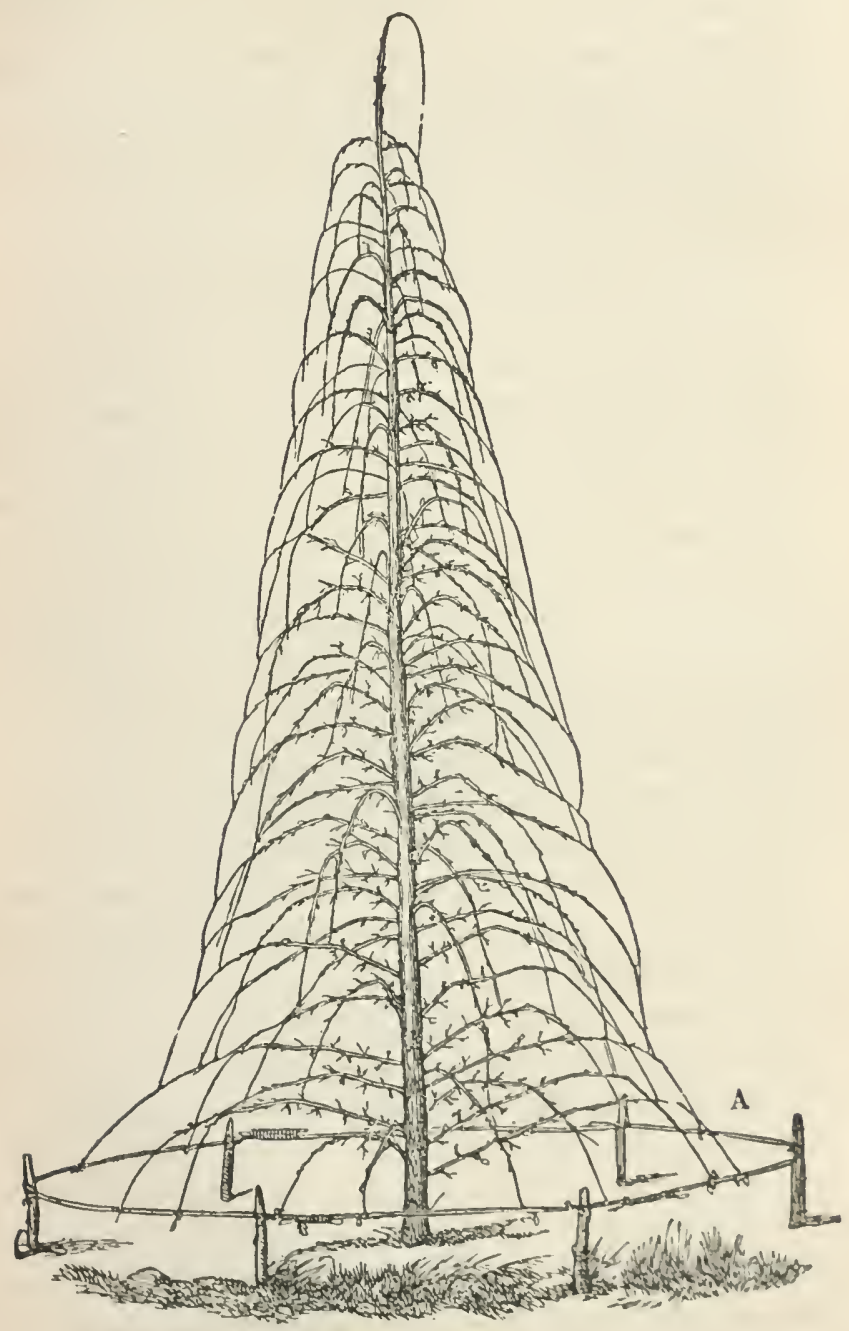


7. Prume when the sap is actire, that the wound may he:al quickly.

S. When trees are tardy in coming into bearing, prune severely in spring, pinch constantly in summer, and rent.prune in early autumn.

9. When a tree has been removed, prune off the branches in proportion to the loss of roots.

\section{SEASOY FOR PRLNLYG.}

MIr. Dowatrg recommended winter and fall pruning of fruit-trees, withont regard to kinds. This is the general practice; but as relates to the Pear, it is beginning to be thought erroneons by the best pomologists. Wounds made in winter pruning cannot heal over until the sap sliall deposit the matter that ripens into bark and rood. In the meanwhile, the raw cut becomes dry and checked, the end of the branch usually dies down for some distance, and requires a new cut in the spring. The best season for pruning the Pear is after the buds begin to swell in April, until the new leaves are half formed.

All the wood that requires remoral shonld be pruned at this season, to economize the sap before it has been wasted in wood growth, that will need to be pruned away. Pruning, howerer, beyond the 1st of July should be avoiderl, as it induces a late sueculent growth, that remaining umipened, is subject to blight.

BOUT-PJUNT.KG, AND ITS MFFICT ON SIAPE $\triangle$ ND FIUITING.

It has long leen known, that an obstinate variety growing on the pear stuck, might be hastened in its 
fruiting, by separating some of the roots, thus cutting oft the abundant supply of nutriment that increased the wood-grweth at the expense of fruit formation. The first object of this process is, to produce fibrous roots, instead of the long, naked ones which support the tree; for fibrous roots alone provide the proper sap for forming or sustaining firuit-buds.

When a root is smoothly separated in the last of Alrgust or first of September, with a sloping cut from the under to the upper surface of the root, the returning sap forms upon the edges of the cut innumerable fibres and rootlets. The tendency to form roots at this season from every abrasion beneath the surface is so great, that eren the young shoots of the Pear will form roots, if half eut through and layered.

The effect of root-pruning is to render the pear tree more manageable; its growth being more equally distributed around the tree, instead of assuming the rampant form of the gonrmand. Most varietice, tardy in bearing upon the pear stock, may be hastened six or eight years in fruit-bearing, by root-pruning. The Dix, Seckel, Beurré, Bosc, and others, that are arerse to the Qunce, by root-pruning may be fruited in four or five years. Pear trees, several times root-pruned, may be removed with almost absolnte certainty of success, at almost any age or size; so that the fil rorite trees of a temant may be remored from the premises he quits, with his fumitnre, and the regret at leaving objects of care and skill may be entirely aroided.

Upon this subject, nothing can be satid of so much interest, and worthy of so much attention as the forlluwing from Mr. Rirers, of Sawbridgeport, England. 
Mr. R., it should be said, confines his remarks entirely to the Pear upon the quince stock, while instructions for root-pruning generally refers to the Pear on pear ronts. Mr. Rivers says:

"I must premise, that handsome and fertile pyramids, more partienlarly of some free-bearing varieties, may be reared without this annut, bieunial, or triennial operation. I hare a large plantation of pear trees on chinee, which bids fair to make handsome and fertile pyramids, yet the' have not been root-pruned, neither do I intend to root-prune them. But I wish to impress upon my readers that my principal object is to make trees fit for small gardens, and to instruct those who are not blessed with a large garden how to keep their trees perfectly under control; and this ean best be done by annual, or at least, biennial attention to their roots; for if a tree be suffercd to grow three ur more years, and then root-pruned, it will receive a cheek if the spring be dry, and the crop of fruit for one season will be jeopardied. Therefore, those who are disinclined to the annual operation, and ret wish to confine the growtl of their trees within limited grounds, by root-pruning-say once in three years-should only operate upon one-thred of their trees in one season. They will thus sare two-thirds in an unchecked leafing state; and those who have ample room and space may pinch their pryramuls in summer, and suffer them to grow to the height of fifteen or twenty feet, withont pruning their roots. I have seen avenues of such trees, in Belgimm, quite imposing. Pyramidal trees on the quince stock (and we rould add, on the pear stock also), when the fruit-garden is smull, and the real gardening artist feels a pleasure in keeping them in a healthy and fruitful state, by perfect control over the roots, should be operated upon as follows: $A$ trench should be dug around the tree, about eighteen inches from the stem, every antumn, just after the fruit is gathered, if the soil be sufficiently moist-if not, it will be better to wait till the usual autumal rains are-fullen, and the roots carefully exanined, those inclined to perpendicular growth, cut with a spadr, which must be introduced quite under the tree on all sides, so that no root can possibly eseape amputation, and all the horizontal roots excrpt thos that are small and fibrous, shortened with a knife, to within a circlorighteen inches from the stom (if they hare not spread out to this extent, they need not he pruned, but merely brought near the surlise and spread out), and all broughts near the surfuce as possible, 
flling in the trench with compost for the roots to rest on; the trench may then be filled with compost and the mold from an old hot-bed, equal parts will answer exceedingly well; the surface should then be covered with half-rotted dung, and the roots left till the following autumn brings its annual care. It may be found that, after a few years of root-pruning, the circumferential mass of fibres will have become too matted, and that some of the roots are bare of fbres toward the stem. This will cause them to girc out fibres, so that the entire circle of three or more feet around the tree is full of fibrous roots near the surfice, waiting with open mouths for the nourishment anuually given to them by surface-dressing and liquid manures. Handsome pyramidal trees may be produced by shortening the shoots in the summer, and if they are inclined to grow too vigorously, occasional (say biennial or triennial) root-pruning by the spade, will be sufficient."

I here introduce MLr. Rivers' plan of root-pruning, although quite madapted to our necessities, in order that the reader may have an opportunity of observing what is called high cultivation.

It should be minderstood by every one that reads this article, that the requisites for forming frnit-spurs are, fibrous roots well supplied with nutriment. While the trees are making only long eane-like roote, there will be no supply of sufficiently-digested pabulum for fruit.

The intention of most cultivator's in this comtry being to produce large pyramids, the annual pruning of roots would be an unnecessary labor, especially on the quinee stock. On the pear stock, biemial rontpruning, by thrusting down a spade, after haring dug a trench one spade deep, at the proper distance firom the stem, is sufficient. One other variation from $\rangle_{\Gamma}$ ?. Rrvins' recommendations is the time in which this root-proning is to be performed. If it is delared until all frut is grathered, the Ticar and the Winter varie- 
ties wnnlal lose the benefit of the desecnding and rootforming salp when the leat is ripening. On the quince stock we have not often found that pear trees need root-pruning, sinee the great difficulty is to restrain their fruit-bearing tendency. The great cause of failure in cultivating these trees is their enormous overbearing, producing one great crop, and then remaining unhealthy, exhausted, and stinted for sereral years.

But, we repeat, in order to grive emphasis to the truth, that root-pruning is quite necessary to the perfection of the pyranid torm, unless the tree has had its training commeneed with the young shoot from the bud. 


\section{PART VI.-DISEASES OF THE PEAR.}

The Pear has several times in this country been subject to most fatal epidemics. Men and animals are not alone the vietims of pestilenec, bnt Nature suffers these violent perturbations through all her dominions. It is not surprising that the sudden loss of one tenth of a fine pear orchard should discourage and alar'm the fruit-grower'; still he onght not to forget that its canse is exceptional, and will pass away. These diseases, though prevailing for several seasons in succession, ocenr only at long intervals; and the period of a disease being terminated, we may usually calculate upon exemption from it for a considerable time.

\section{WINTER, OR FROZEN SAP ILIGITT.}

The diseases of the Pear, known by Pomologists as Leaf-Blight, Summer-Blight, Winter-Blights, InsectBlight, and Frozen-Sap-Blight, are generally, at present, recognized under the two latter terms, though we think the leat-blight an entirely distinct discase. There las been so muel speenlation upon the callees of Winter or Frozen Sup Blight, and so many remedies recommended, that we are not prepared to adopt any of the theorics in explanamion of $i t$, or any nostrim as a specific.

The pear tree is a greerly alborlere of fluids, and $(173)$ 
When the warm rains of September excite its absorb('nts, the gourmand drinlis up large quantities of nutriment, and a late and rapid growth of shoots is formed. In these suceulent and mripe growths, the Eap is retained without that vitality of leat which will efliet its matmity and assimilation, being thin and watery, and not sufliciently matured to enable it to resist the frost, and death ensues. In the plant as well as the animal, great length of time often elapses before the poison aftects the whole system and causes death. It is not unfrequent that the tree, poisoncd in antumn, surves till the July following. The bark of the trunk and principal limbs exhibits black spots; and on cutting into them, the bark and wood, for some distanee beneath, are found quite dead and black.

'The only remedy is, to ent away at once all of the tree that is affected, cutting below the lowest spot. But few trees attacked with this disease will be of much ralue, even with the best treatment that can be given them. Ont of forty trees, six or eight feet high, thus affected in one seasun, we sueceeded in saving the stmmps, two feet high, of only eight or ten. These treces had been brought from a distance, and planted the fall preceding the attack, and exhibited ly their large, thrifty shoots, that rapid, mripe growth abore mentionerl.

The most enceesful means of saving trees from the ravages of" this discase is to aroul its attack. The canse being late and unripe growtl, it most frequently oceurs on over-rich and damp suils, retentive of water, and abomuling in verectalble and animal matter. To remove the execes of water, the best, and indeed the 
only means, is draining; the surplus rank regretable and animal matter must be neutralized or decompozed by the application of alkaline substances-ashes, lime, marl, \&c., which, as all experience shows, insure by their direct influence on the sap, a short, stocky, and well-ripened growth. Fifty bushels of lime, and half that quantity of ashes, scattered orer an acre, and worked in with the plow, is an almost certain preventive of this disease, if previously well drained.

A strong evidence in support of this theory, is the fatct, that this blight has never been known to originate on the dry sandy loam of Long Island, not even with heavy manuring; the drought of midsummer always ripening the shoots so completely, that the leaves fall a month before frosts commence.

If the character of the season and the continued growth of the trecs, indicated by fresh green leares and lengthening shoots, late in the fall, warn the cultivator of danger from this disease, lie slould remore the earth from the collar of the tree, down to the first roots, and around for some distance. This exposmre will clieck the tendency of the roots to absort more mutriment, and of comrse arrest the growth. The same resnit may be gained by root-pruning, whenerer the other method is not convenient, or proves insufficient.

This discase, the most formidable that attacks the Pear, is distingruished by certain peculiar signs:

1. At the time of winter or spring pruning. hy a thick clanmy sap flowing slowly from the wounds -while a healthy tree exhibits a fresh, clean cut.

2. By the appearance, late in spring, of dead patches of bark on the trunk and linbs. This, howerer, is 
sometimes the (onseyuchec of overbearinger, in which calce, the dead hark will often eover the living and most healthy wood and hark; yet this peculiarity is frequently the tirst stage of the disense.

3. Div the extremities of the shoots in early summer slurvelling, turning black, and perishing sudolenly When these ane justantly cut away for some distanus beluw the discatienl parts, the tree may often be saved hite if the deanl pittehes of birk, above mentioned, fir:t male their apjearunee, the car-e is eritical.

TII: INEE(T-JHLIGIIT.

The insect causing this blight is kuown anougr pomolugists as the seolytus myri, and is one of the most minute of om numerous anemics.

In July ol August it proforites shoots of sometimes two scasons growth, and deposits its ergr. The succeeding onne or July, the branch is observed to wither and turn suddenly brown. The disease seldon tratrels below the point attacked, and it the part be removed immediately, is directly checked. The insect engrendered neitr a bud eats its way to the pith, and there. by feeding upon the sap-ves=els, destruys the ongani=m that supplies life to the upper shent. At the first alprearause of the ravagers of the insect, all the branches aflereded should be cut and burned-the at fack must be sudden and energetic.

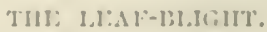

This diecase is indieated by an sudden spotting and premature ripening of many of the leatves. 'The growth is checled for at time, and if the attack is loms- 
continued, or wide-spread, the fruit is lessened in size, and sometimes refuses to ripen. It is only ecrious, when appearing upon Pear seedlings, as it checks their growth, and prevents their being budded during the season of its attack.

It is very probable that the winter-killing of seed. lings results in great measure from the previous feeble growth, as the roots produced are in exact proportion to the quantity of leares, and the active vitality of the leaves being destroyed, the roots are too feebly dereloped to retain their hold in the soil. A curions fact in the history of this disease is, its confining its attacks almost entirely to seedlings and wild pears. A graft or bud of the finer rarietics, of the greatest luxuriance of foliage, may not exhibit a single symptom of this disease, while the leares of the stock will be entirely blackened. Its approach may be looked for, whenever warm and abundant rains are sncceeded by hot, bleaching sunshine. The leaves of pear seedlings being very sucenlent, and in such a season as just described, accustomed to a moist atmosphere and a shaded sky, are not prepared for the great cliange, and consequently are scorelied and blackened. When occurring in the secel-bed, I do not doubt that the close planting of the young trees occasions this result. 


\section{PART VII.-INSECTS INJURIOUS TO THE PEAR.}

TIIE Scolytus pyri, already mentioned, is a very minnte bectle, not much linger thin a flea. It punctmes the young wood of the pear shonts, and deposits there its eggs. It is the larva of this insect that accomplishes the mischicf. It is thus described by Dowrixa: "The beetle is al iecp brown, with legs of" a paler color; its thorax is short, convex, rough in front, and covered with erect bristles. The wing covers are marked with rows of punctured points, between which are also rows of bristles, and they appear cut off rery obliquely behind." The larva completes its change by June or July, and gnaws its way through the bark, leaving a small romd puncture.

\section{THE SCAIE IXSECT.}

This abominal, le and prolific muisance is insignificant in appearance, but formidable in mischief. Trees of clean, smooth bark, sometimes in the single month of September, become so foul with this insect as to appear covered with bran-scales. These seales are not the insects, but cover small reddish cocculi, that when ernshed with the finger-nail leave a spot of blood. 'They feed upon the more sluggish juices of the trunk and limbs. In a short time the tree becomes 
so infested with them, that the most vigorous efforts must be exerted to clear it of the enemy. Some of my trees had, by neglect, become so badly affected, that I saw no remedy would preserve them, and was compelled to cut them down. When the cocci are washed away, the bark appears rough and blotched, and presents a diseased appearance.

Wasires. - A solution of soda, or potash in water, not stronger than one pound of soda to one gallon of water, or one pound of potash to two gallons of water, is efficacious. But washes of this strength must not be applied to trees in foliage.

Whale-oil soap, dissolved at the rate of one pound to three or four gallons of water, is a most effective wash, and the efticiency is increased when the soap is dissolved in a decoction of refuse tobacco. Camphor is sometimes added; but this gum is somewhat costly. The wish of whale-oil soap may be used stronger, if applied when the leaves have fillen.

For the following, I am indebted to the pen and pencil of Mr. A. O. Moorz.

"If in the month of October the vigilant cultivator scrutinizes his young pear trees, he may be surprised at finding many of them strangely covered, on trunk and limbs, with a white substance, which at first may seem to be a mold or mildew, such as would be engendered by a damp situation. Upon attempting to scrape this off, a claretcolored liquid will smear the stem as if with blood. A close eximination will show that this white substance is composed of small paperlike scales. If a seale is removed carefully so as to expose the under surface, it will at this season be found to eover a minute dark-led object, surrounded by jet smaller dust-like atoms. This is as fir in our investigation as the unaided vision will eary us. A good microscopic lens will, however, reveal a funily composed of a mother (ih seen at 
Fig. 5i) with her aumerous unlatehed progent, consisting of from twenty to fifty engs-the lireaking of which latter furnished the red fluid before noticed. After the egors have been deposited, the body of

Fig. 56 .

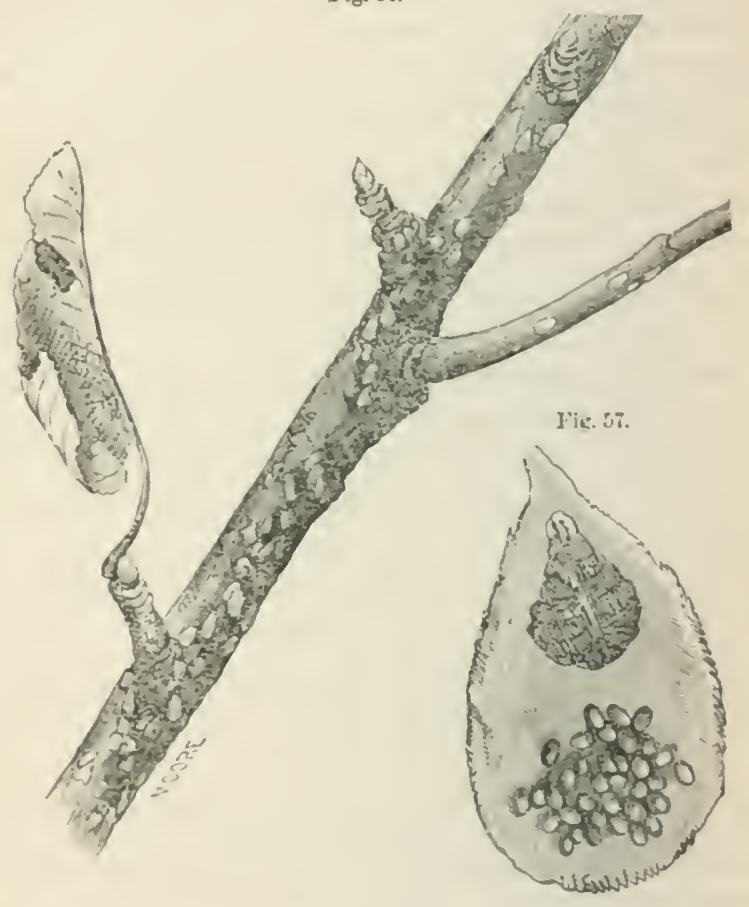

Fig. Sf represents a Pear brancb attacked by the Bark-Lonso. The insect being soncealed under the white scales.

Fig. 37 represents the under side of one of the scales, with the eg:s adbering, Fre:tly unspnined.

the fomale contracts, ne shown in Fig. 57. Privinus to the first of netolwre, I hawe found the ineret unler the seale without the regs, but by arranging the light so as to prorluce a slightly transparent effect, the egga may then lec sucu within the bouly of the parent, ns ut Fig. 58. 
"At this time the insect appears almost lifeless, and probably it has alrealy committed all the injury to the tree it is capable of inflicting: this injury consists in the abstraction of the juices of the tree. Around each minute paper domicil may be seen a discolored spot. It is not unusual to see a tree of eight or ten feet in leight with every part of the stem and many of its branches whitened by this injurious insect. No tree thus attacked can be healthy.

"Trees situated in grass lands, or otherwise neglected, peculiarly invite this sloven's pest. Slow-growing varieties of the Pear are more subject to it than the rapid growing kinds.

"We will now consider the means of destroying this troublesome insect. It is probable that the time in which the injury is committed is during the summer months, although the insect, being not then invested with its paper-like covering, can only be discorered with diffculty. The practice of washing the trunk and main branches of fruit. trees with a mixture of soft-soap and water, one part of the former to two of the latter, applied with a coarse cloth, using considerable friction, cum not be too highly recommended for the health and general thriftiness of the orchard. This application should be made in the spring, before the swelling of the buds, and again in early June-this time, however, greater care is necessary to aroid injurs to the young shoots. The young insect is then about commeneing its sumuner denredations, and all that escaped the sping washing may be easily destrored.

"Where soft-soap can not be obtained, common hari-soap nay be used instead; half a pound dissolved in two gallons of hot water. Harris recommends a solution of two pounds of potash in seven quarts of water, or a pickle consisting of a quart of common salt in two gal. lons of water. To preparation, lowerer, I believe to be so safe and efficacious as the one first mentioned.

"Whale-oil soap, or eren common lard-soap, placed in the 'croteh of the priscipal branches, and allowed to remain until washed down gralually by the rains, will he fouml excellent for the general bealth of the tree, and prevent the attacks of this and mans other insects.

- Fig. 3 is a magnitied view of the Female Bark-Louse before depositing her eges 
"Another species of the coccus lias lately been brouglit to iny notice, which seems to allect the Apple and the Pear in the same manner as the above, and is sonetimes found upon the same trec. It has, instuad of the white paper-like corering, a liard coriacious scale, of narrower and louger shape, and the eggs are pearly white iustead of red. I fear that where this insect exists, it may prove a more troublesone enemy than the white seale, as its hard covering forms a more effective protertion against the wash recounmeuded."

After the cocens has aequired its shell, a simple washing will not remove it. It must be scrubled off with considerable forec, and in bad cases, with sand and soap.

\section{THE SLUG.}

The pear-slug is another insignificant, but troublecome enemy. This slimy and disagreable fellow attaches himself to the upper part of the leat", in Junr or July.

It is about half an inch long, and somewhat resemhles a suail. It quickly devours all the succulent portion of the leaf, the skeleton of which remains upon the tree, and appears as if scorched with fire. Growtl is stopped at once, and what fruit has set, never attains any considerable size. Dust, lime, ashes. and other substances, that will attach to the slime of the insect, will, if thrown upon the leaves where it is feeding, soon detach his hold, and canse him to fitl off and dic. Soapsuds, potash-water (made with six or cight gallons of water to a pound of potash), or strong tobacco-water, will speedily destroy this insect.

I am happy to be able to add the result of enme investigations into the habits of this insect by Mr. A. O. MLoris:

"The insect which we familiarly call the l'eur Silug (Schandria cerasi, ) 
represented in Fig. 59 is, at the period of its life when generally noticed by the cultivator, a greenish-black, club-shaped worm, with a thick rounded anterior extremity, and tapering towards the posterior. It is covered with a semi-transparent eoat of slime, which exudes from the body, and, in the hottest sunshine, does not become hard or dry.

"While resting undisturbed upon the leaf, the tail or last segment of the body is slightly raised. At its greatest size, the worm is about half an inch in length; it is very sluggish in its habits, being rarely seen to move.

"The injury consists in its eating the upper skin of the leaf, while tho Fig. 59.

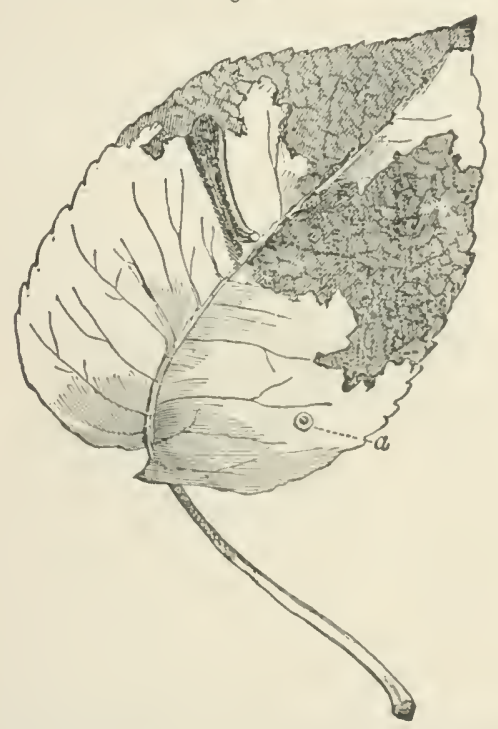

Fig. 59. The Pear-Slug full grown. The Leaf whth its upper eurface partially destroyed. (a.) The Egg deposited upon the upper surface of the leaf

lower shin and the veins are untonched; the leaves inmediately assune a brown, unsightly appearance, while the proper function of the lenf, the elaboration of the sap, is almost eutirely obstructed.

"Liko all other insects, its existence may be divided into four stages: First, the Egg; second, the Larra, or worm state, which is peculiarly its eating and growing period; third, the $P u p($, or dormant state; 
fourth, the Imagn, which is the perfect or winged state. In this last stage ouly are the dillerues of sex discernible; and hy the Fly, or perfeet insect, the egg: are deposited which reproduce the brood of destructive worms.

"This tly of the Pear Slug is described as a four-winged Hymonopter. ous (or wasp-like) insect, of a glossy black color. The wings are somewhat convex on the upper side, and slightly wrinkled, trausparent, reflecting the eolors of the rainbow, the anterior pair having a smoky band across them. The legs are tipped with a dull yellow color. The hody of the female measures rather more than a fifth of an inch in length, that of the male is smaller. They make their appearance twiee during the summer, the: Grst time about the end of Jiay or the first of Junc, the second appearance about the litter end of July. On each oceasion they lay their eggs, and disappear in about three weeks.

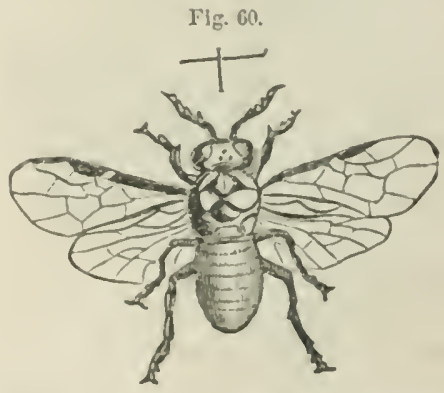

Fig. 60. The Perfeet Insect or Fly of the Pear Slug-nngenified. Tho cross lines represent the aatural slze.

"The slug fly deposits its egges singly on the upper surface of the most matured leares, covering it with a frothy, white, rarnish-like mucilage, which surrounds it, ant serves at once to attich it to the lear, and to exelude the atmosphere. The small spot a on the leaf, fig. 6.3, represents the size and form of the egg, which is seen as a dark ernter in the naiddle of a white spot. Fig. 61 represents the eng magnified, and the worm or young slug within the semi-traneparent slyell. Fig. 62 exlibits the egg also magnitied, after the inwet has emerget.

"W"luen first hatched, the young slug is white, and ean wish diflienlty for diserrund by the naked eyr ; it enmmenes immedintely lo puncture with small holes the surface of the leaf npon which it is prodnced. It 
soon acquires a corering of greenish-black slime, and is said by HA HRss to live as a worm twenty-six days, shedding its shin during that period

Fig. 61.

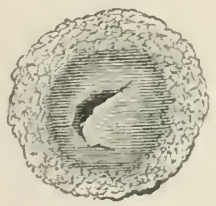

Fig. 62.

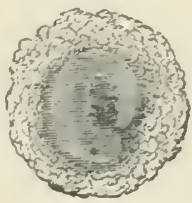

Fig. 61. The Egg magnified, with the Embryo Slug eeen through the shell,

Fig. 62. The Eigg empty after the Slug has escaped-magnified.

five times. Fig. 63 gires its appearance after it has shed its shin for the last time, with the forsaken skin lying near it. It is now much changed in color, being a brown-yellow, and somewhat diminished in size. In a few hours it falls to the ground, and immediately secks to burrow into the soil. Desending to the depth of several inelies, it forms a cocoon with a shiny brown interior surface, and a rough exterior, with grains of earth adhering. Fig. 64 shows a broken cocoon with the

Fig. 63.

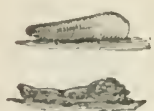

Fig. 64 .

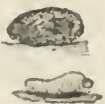

Fig. Că.

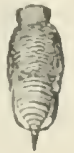

Fig. 6:. (u) The Slng, after strelding its skin the last time. (ל) The skin left unwn the Itar.

Fi... 64. (4.) The Cocnon from which the insect has been prematurely remoret. (d) The Slug after having commenced its change to tho fly state.

Fig. 65. The Ichnemmon Fly magnified; supposed to be of tho species Lincyrtus, taken from the egrg of the slug.

insect, now mueh further diminished in size, taken out. This is the Pupa or domant state. It remains in the earth after ita first appearance sixteen days, when it comes forth as the perfeet insect, Fig. 60. The second brood remain in their subterranean retreat until the suce eceding spring.

"We will now consider the means for preventing or palliating the injury resulting from the attacks of the pear-slug. I wonlel first remark, that the slug is found in much preater abundance on weahly growing trees than on those of strong and rayid growtl. This fact points to 
the first anul funlamental remedy, the seeuring of healthy trees, and by the propure curichment and preparation of the soil, of a thrifty and unifurm growth. Sature has provided a minute but formidable enemy to the slug, which serves very materially to check its increase. This eneny is a species of ichneumon fly, which is also of the wasp family. Soon after the slug $8 y$ has deposited its $\mathrm{egg}$ on the leaf, the ichnenreon deposits its egg within the shell of the former, which developing to 2 minute grub before the time for the hatehing of the slug worm, feeds upon the embryo slug, passing the whole period of its existence as a worm, and even undergoing the succeeding transformation through the pupastiste, within the small space aftoriled by the egg of the slug, the nitural size of which may be seen at $a$, Fig. 5 s.

"Fig. 65 exhibits the ichneumon tly as found in the egg of the pearslug, nearly reuly to emerge as a perfect insect.

"The application, at the proper time, of lime in a $1 \mathrm{ry}$, or powdered state, while the leaves are wet with rain or dew, will prove effectual in destroring the egg before it is hatehed, or the slug during the time of its depredations. If the rumber of trees to be treated is large, it will only be necessary to apply the remedy twice during the season, provided the proper stage of the insect's derelopment is thosen. This should be as soon as possible after the eggs are all hatehed, which is usually ahout the first of July with the first brood, and the frat of September with the second broot. If applied earlier than the times mentioned, some of the eggs will not have hatehed, in which case it requires much greater eare and a larger quantity of lime; or if applied much later, many of them will have undergone their transformation into the pupa state, and therefore lie beyond our reach. I have found this remeds always eflieacions, and even plaster of Paris, ashes, or dust from the road, applind to the slimy coat of the slug, will catuse it to sichen and lin."

"A. O. M() MB:."

"XEW YURK, 140 Fulton Strcet, Oct., 1857."

The caterpillar, canker-worm, and apple-worm, which increase in size and number with such rapidity, are eatsily lestroyed when attacked in tine. The web must he crusherl at its first alpearanee. The best methen is not always the most pleatsant; but all the operations of horticulture are not equally agreeable. 
A thick buckskin glove should be worn; and with the hand thus protected, the nest should be grasped and crushed-being careful to press firmly all the crevices of the bark to destroy every individual.

There is but one method better, and this is to look carefully over the trees sereral times after the leaves have fallen; gather every leaf curled and grummed to the tree, and every circlet of whitish eggs attaclied to a limb, and put them in the fire.

The most effectire and conrenient allies in destroying insects are, birds and dung-hill forls. When the latter are fed at distant and different spots abont the pear grounds, they acquire a habit of wandering arnong the trees, and although generally shy of attacking caterpillars, yet their quick eyes no sooner detect a miller, a fly, or a beetle, abont to lay egres for an innumerable generation, than the hapless insect is deposited in the erop of some of the gallinacice. Wasps, flies, and moths are the parents of rapidlyincreasing tribes, and by destroying one of them, we rid onrselves of thonsands. Wide-monthed rials containing molasses, and lhung in the branches of trees. will catch large numbers: small bright fires makc in various parts of the fruit-grounds, during the nieghts of June and July, will attract and destruy many. 


\section{PAR' VIII.-VARIETIES.}

CONDITIONS WHICIL AFFECT TIIE QCALTTY OF THE FRUIX.

Grkat diversity of opinion prevails in regard to the excellenee of every variety of the l'ear. This arises from the difierent characteristies of the fruit when modified by cireumstances. Some of the conditions unfarorable to the proper development of the fruit are:

First. The fruit of some varieties is small, astringent and insipid, while the trees are young, but large, delicious, and highflavored, when the trees become older.

Seconl. The fruit may have remained too long upon the tree. Many linds are nearly worthless unless picked as soon as the stem will elcare easily from the spur without breaking, and ripened with protection from the air and light. They then become nearly perfect.

Third. Some varieties are only sceond-rate when grown on the pear stock, but when grown on the Quince, are ranked as high as "best."

Fourth. Soils have great infuence on the quality of Fears, ineompafibility of soil often rmining the fruit of the best varieties.

Thus, from lack of knowledgre of these eonditions; many falla. cious opinions have been formed, and much disappointment has followed the attempts to cultivate varicties which, llough "first rate" in their original josition, in other places do not find their special requirements.

THI:HS IREIATLYG TO TIE QUALTTY, SHAYE, \&C.

Best. Pears that are of fine texture, melting, very juicy. and high thavored and the term is applied only to those that possess all ithe qualities denoted by butlcry, melting, juiey; and high. tlasiored. 
Very good, denotes varieties that possess all but one of the abore qualities in a ligh degree.

Good, is applied to those that lack some of the above qualities, or possess one or two of them in only a moderate degree.

Fair, indicates that the varieties have some claim to attention, but not enough to entitle it to a ligh rank.

Poor, designates those entirely uuworthy of eultivation.

Pyriform, denotes the fruit with the small end at the stem, or approaching in form a cone.

Acute Pyriform, fruit tapering to a point at the stem, like the Beurré Bose.

Obtuse Pyriform, the small end rather blunt at the stem, like the Bartlett.

Depressed Pyriform, the sides immediately below the stem sunken, as if forming an ineipient neck.

Long Pyriform, neck very long, as in the Dix.

Obovate, denotes an egg shape, like that of the Vergalieu.

Turbinate, is roundish, but appronching a point at the stem.

Oblate, flattened at the ends like the Bergamots.

Pyramidal, regularly inereasing in size from the base to the stem

Large, a size ranging from the Bartlett to the Duchesse.

Small, ranging between the Seckel and Washington.

Medium, the size of the Lawrence and Vergalicu.

Caly $x$, the flower end, or the leaves of the flower whieh remain on the fruit.

\section{QUALITIES REQUIRED FOR MARKET CULTTYATION.}

In this selection of varieties, it has been the writer's purpose to include none which were of doubtful value, and which have not been proved, by the most ample experience, to be suited to general cultivation. The list is carefully made from comparisons of the experience of the best poinologists, as well as of ordinary cultivators, from Maine to Georgia, from the lists of Pomological Societies, and from the writer's personal expericnee and obscrvation. The rules observed in the formation of this list are:

First. The tree must be hardy, able to withstand severe winters, a strong, vigorous grower, and not liable to erack in the bark, or io blight. 
Second. The fruit must be of fair size, and if not of first-rato quality, must be large, and handsomely colored. 'I'he only cxecptions are in favor of the long known and popular varietics.

Third. The rariety must be prolifie, and come carly mto bearing. The only execptions are those admitted by the next rule.

Fourth. The trees must have considerable longerity, and be not casily exhausted by overbearing.

Fifth. Of the varicties grown on the Quince, only those are admitted which an expericnec of ten years, at least, has proved to possess grcat affinity for that stock, to acquire thereby higher flavor, greater size; and to come considerably earlicr into bcaring.

Sixlh. No kind is admitted upon the list, whatever may be its excellence of flavor, size, or color; if it cracks, cankers, or rots at the core.

\section{VARIETIES FOR MLARET CULTIVATION, TO BE GROWN ON PEAR STOCKS.}

Most of the kinds recommended for growing on pear-stocks may be grown on the Quince: but as their fruit is not inaterially improved in size and flavor, and as they sometimes fail on that stock, they are placed in the list for pear-stocks.

BA R T L T T.

Tilliams.

Wullams' Bon Chritticn.

FIEBT TO FIFTEENTK BEPTEMBFI.

While this beautiful and excellent fruit is not allowed by amateurs to take the first rank, it possesses qualitics which have se. cured to it high exteem, and have made it the most popular variety in this eountry, sinee the decline of the Vergalicu, and it is therefore to be recommended for profitable cultivation. 
It was originally found in Berkshire, England, in 1770, and brought to Roxbury, Mass., in 1797, under the nanie of Williams' Bon Chrétien.

Fig. 66.

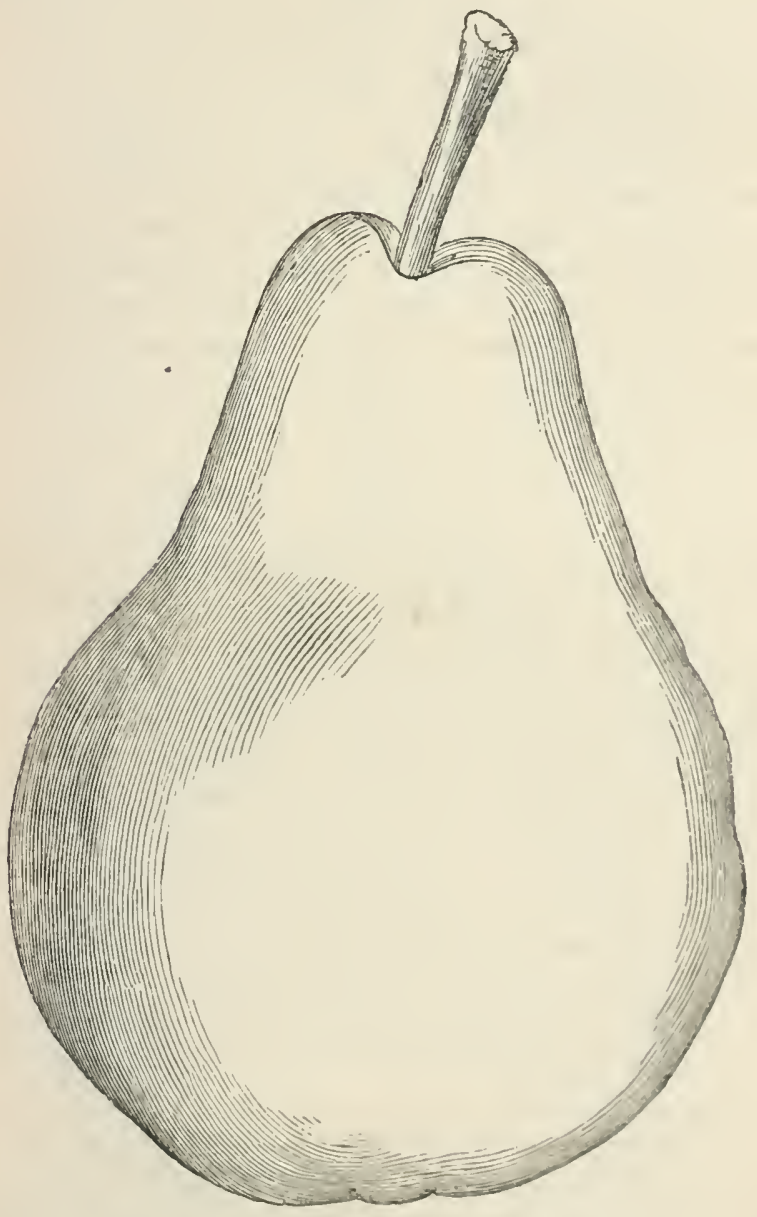

Both in Franee and Fngland it was but little esteemed, and it 
nffords a striking instance of the fallibility of any standard of taste; for, while many consitier it unsurpassed, not a few regard it as inferior.

The ehef dutheulty in growing it results from its precocious and too abundant fruitfulness. The tree coming into bearing at four or five years from the bud on its own roots, is often the first time so overloaded with fruit, that its growth is checked for severa] years, and thus it fails to attain fair size in many years.

On the Quinee, the Bartlett is the most objectionable variety on our catalogue. It grows vigorously for two or three years, till fruiting commences, and then, if it bears abundantly; it perishes soon after; and even if earefully managed, and fruit-thinned, it rarely attains to a vigorous condition. The natural growth of tho Bartlett, unchecked by fruit-bearing, is strong and vigorous; tho shoots cxhibit a peculiar equality of size throughout their entire length, ending abruptly and bluntly.

As a market pear, it has no superior, taking into consideration all its qualities-its early bearing, its great produetiveness, and regularity, the fair size and bright lemon tint of its fruit, its melting, buttery flavor, and its universal popularity. The fruit possesses a peculiar musky aroma, which somewhat affects the taste. The pears exhibit a remarkable uniformity of exeellence. There is not that inequality in the proluct of a tree, that is found in some varieties-a part very good and a part very poor.

The fruit may be pieked when quite green and hard, transported long distanees withont injury; and still ripen with perfeet flavor and high eolor. The Bartlett has, however, some defeets. It is more subject to blight than most other varieties-a consequenee of its strong: succulent, protracted growth. It eannot be grown on the Quince with success. Its fruit ripens when o:her fruit is most abundant; all the late summer and early antumn fruits disputing the market with it. But it has the adrantage of producing gond crops every year.

The Freuch make it sueeed inmeh better than others on the Quince, and they propagate it on that stoek largely. Having a large number grown on the Quince sent me one spring from France, by inistake, I planted one hundred and fifty-then ordinary-sized 
nursery trees-closely together, and allowed them to fruit the next year. They produced thirteen bushels of handsome fruit, which I thought compensated for the death of half of the trees the next season.

Épine Dumas.

I)umns.

J) Rachois.

Berle Épine Dumas.

\author{
Dumas de Rocheiort. \\ " de Limoges.
} OOTORER.

Fig. 67.

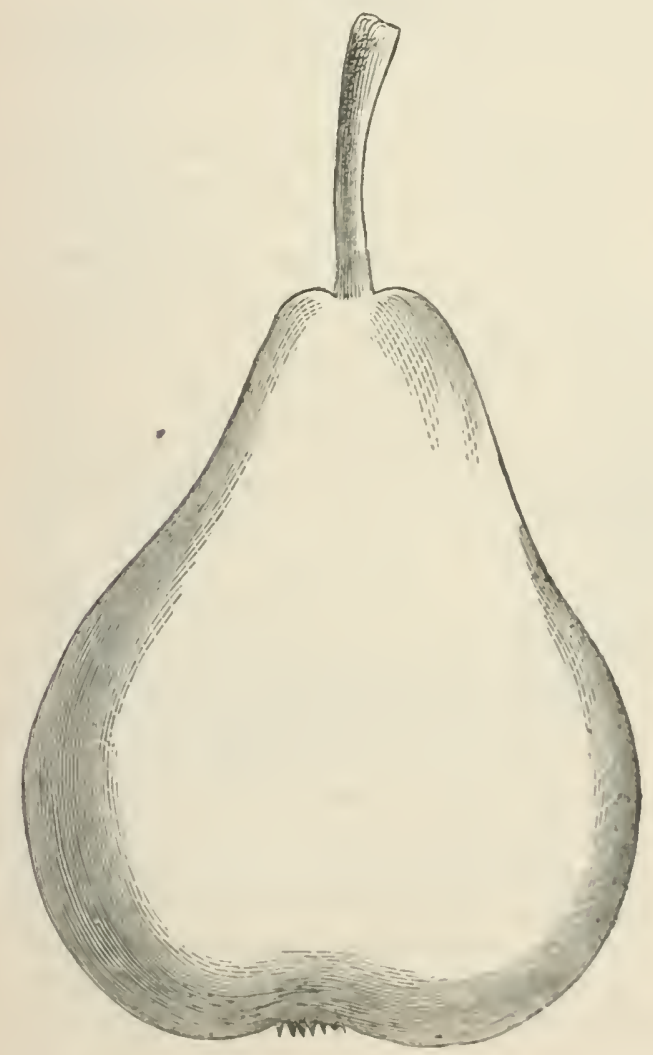


This pear, when more fully linown, must, attain a very great popularity. Its areat beauty is only equalled by its execllenee. The tree is vigorous, hardy, and productive, and has the remarkable peculiarity of producing its fruit in the eentre around the hody, seldom bearing on wood less than three years old.

The fruit is of mediun size, obovate pyriform, very smoothskimed, and free from stain or rust, ripening to a light, but rich greenish yellow, and full of a sparkling, elnampagne-flavorel juice, melting, but not quite buttery.

The number of its synonyms is indicative of its wide-spread reputation in Europe, and we belicre it will cxeel in this country; as it is one of the very few varieties that have improved by im. migration.

On the Quinee, it is a stocky, vigorous grower, but forms the weakest union of all the varicties, not exeepting the Bartlett. The pear-stock is decidedly preferable inr this variety. I have not been able to detect any great change in the flaror produced by growing on Quinee, but it thus comes earlier to bearing, and is more productive while young.

\section{BeLLE LUCRATIVi:}

Bergamotto Lnc.

IBeurre I.lle.

Bergamotle Flérée.
Selgnenr d'Fuperln. Fondante d'Autumne. Groseillière.

OOTOB B B.

A prolific variety, of greal beauty; and of such execllenee of favor as to obtain the highest praise from all pomologists. The beanty of the fruit, well exposed to the sun, exeites extravagant aduiration. Tho rich gold ground is irreqularly mottled and strijed with red and purpli-h shakes. The fruit, sonewhat variable, las a mean size, about equal to the Vircalien: its shape is uniformly romelish obovate: quite broad at base in proportion to its height. The ealyx is rather snall, set in a broal, shallow basin; the stem is little more than an inch in length, stout; often fleshy.

I think this fruit eombines the highest exeellenees of flavor and texture. It is cutirely melting, with a sugary, vinous flavor, and most abunlant juice, n thin skin, and sinall core. 
Some pomologists eomplain of its slow growth and unhealthiness on the Quinec; but when properly treated, I lave been abundantly satisfied with its vigor and healthfulness.

Fig. 68.

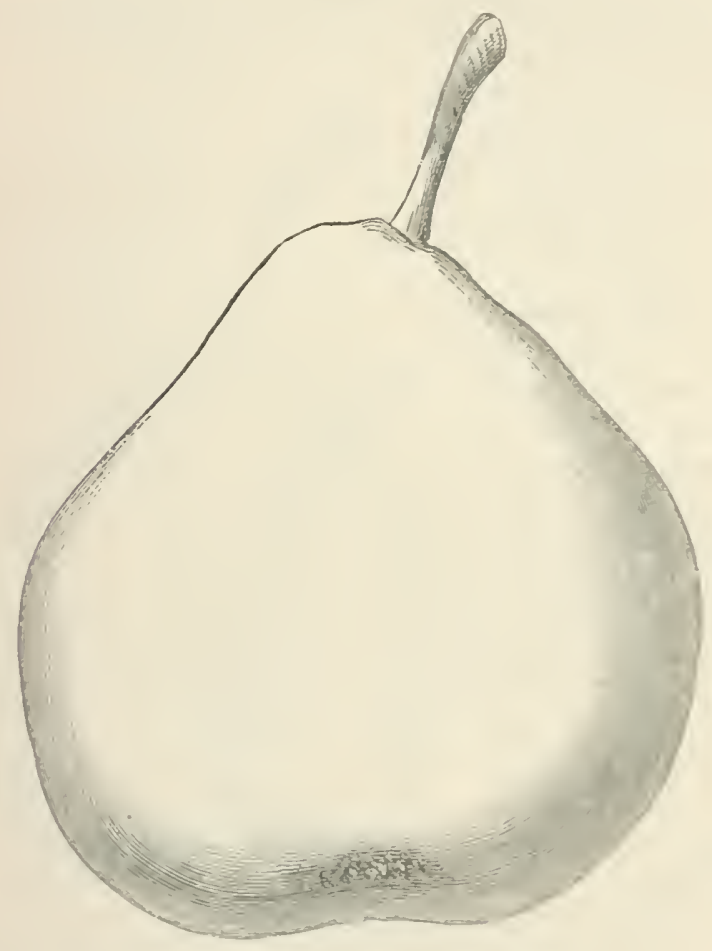

The fruit is borne in elusters, the tree is very productive, thin. aing being often necessary to prevent injury from over-bearing. 
Br. ตnt:onn.

L $\triangle$ B T O $Y$ JU L $Y$.

This variny originated on Long Island, and was namel from tho proprietor of the Bloodgood Nurseries; and considered by him a secdling.

It is the most generally liked and cultirated of the early pears, being one of the very few that have high fla. vor. Some, however, give a higher place to the Julienne; the Rosticzer, and Dearborn's Seedling; but, after a comparison of the execllences of all, I consider the Bloodgood the most profitable market early pear. The tree is vigorous and hardy; of a peculiar stout,fine-looking growth, with short joints, and a reddish brown color. It comes into bearing carly, and is productive.

The fruit inust be gaFig. 69.

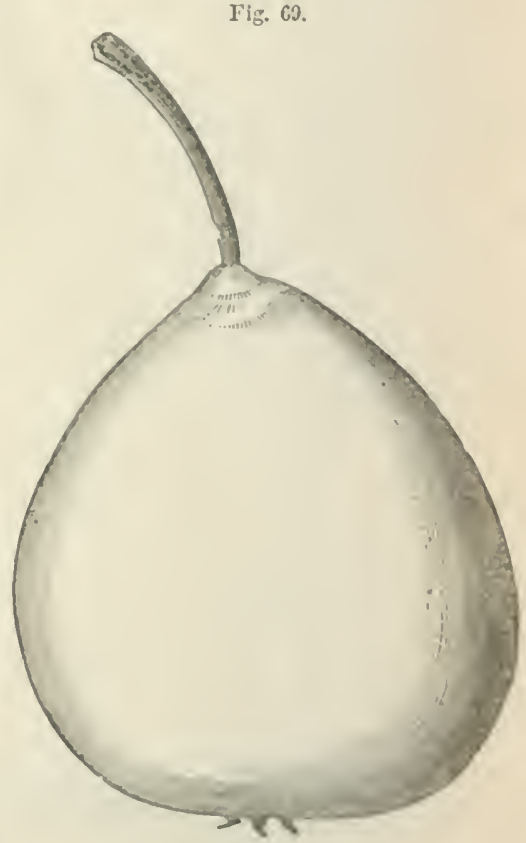
thered before ripening, and matured under cover. It is small, and of a thick turbinite form. The skin becomes yellow in ripening, with russet on one side. Stem moderately long, curved, s]cuter, and brown. the flesle extending up upon it. It is quite meltin: when well ripened, with the most perfumed and aromatio favor of all early pears. 
BUfFAM.

O O

It seems unaceountable, that so valuable a variety as this should be so mueh neglected. I am Fig. 70.

aequainted with an orchard of this fruit that has borne regularly for more than twenty years, yiclding enormous crops.

This variety is native of Rhode Island; it has a characteristie, upright growth, tlie branches shooting up almost parallel with the body.

The fruit is beantiful, ou one side of a dull red, shading to yellowish green on the other ; ordinarily, somewhat smaller than the Vergalicu, - but when thinned, of equal size, growing in long, rope-like

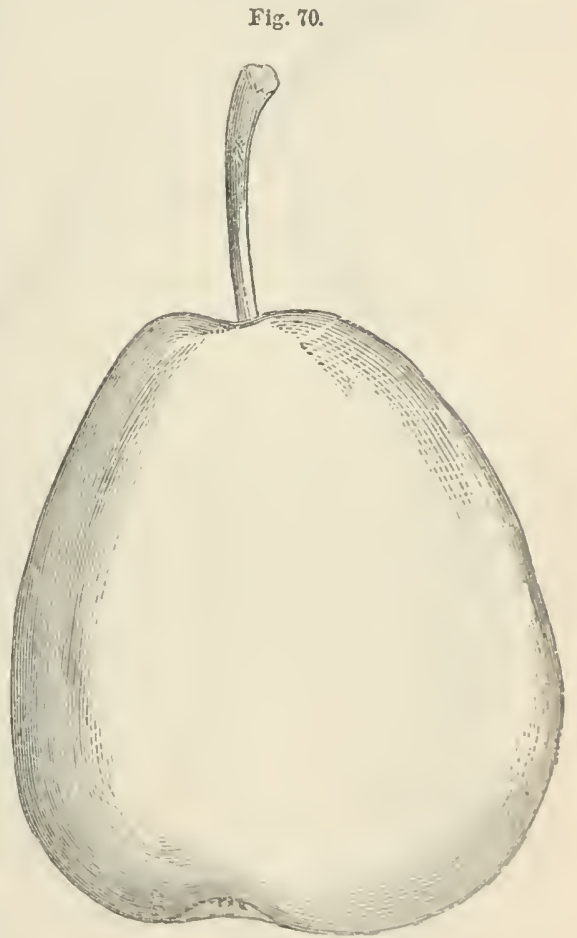
clusters; and when in perfection, delieions with abundant sweet juice, peculiarly aromatie-often as goou, I think, as the Seekel or Vergalien, but tending to mealiness when over-ripe. 
Colimbia.

N O V I B E R TO JA N U B Y

Fig. 71 .

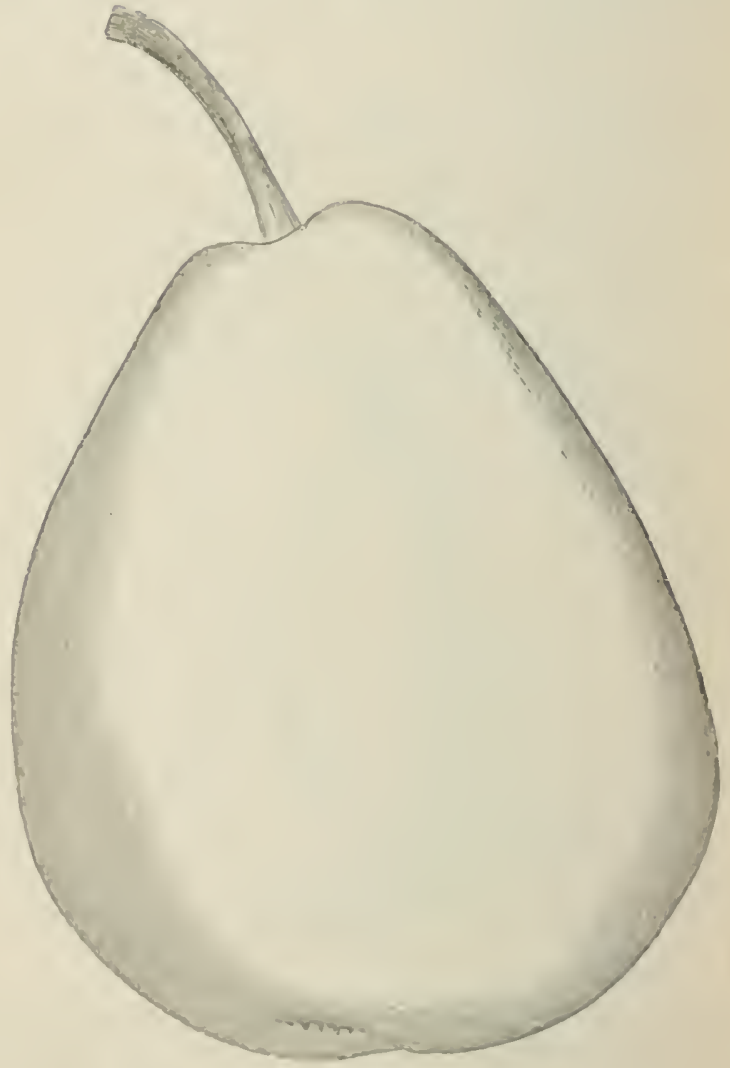

This variety originated in Westehester County, N. Y. Sup. posed to be from scedlings planted by the French Huguenots. Its 
growth is upright, not unlike the Dix, shoots strong and vigorous, of a yellowish brown. The tree is hardy, grows rapidly, and is very produetive. On account of the long slimstem, and the weight of the pears, they are liable to be blown off, before maturing, by high winds. The trees should, eonsequently; be trained low.

The fruit is large, obovate pyriform, but broadest in the centre. The skin is quite snooth, of a dusky green before ripenmg, afterwards of a greenish yellow, and often golden. Stem set somewhat to one side.

The fruit is very juicy, of rich, pleasant flavor, when well ripened -requiring less care in ripening than nost others, and although not melting, and often coarse, is still one of the best market varietics. Its keeping qualities constitute an important exeellence. I have scen this fruit in the windows of fruit-shops as late as the middle of Jamuary, ripening up to nearly first-rate flavor without care.

It is a favorite with marketmen, on account of remaining so long in perfection, its freedom from rot, its fair skin, and the high priec obtained for it near the holidays. At that season, it is often sold for two dollars per dozen. While there are many wintes pears of ligher quality, the Columbia has hitherto stood the strong test of peeuniary profit, under which better fruits have entirely failed. 
DorexNé Boussouck.

Double linlippe. locurre do Nisude
Nouvelle Bousinute New boussuluck

O OTOBE 16 .

IVI. T.

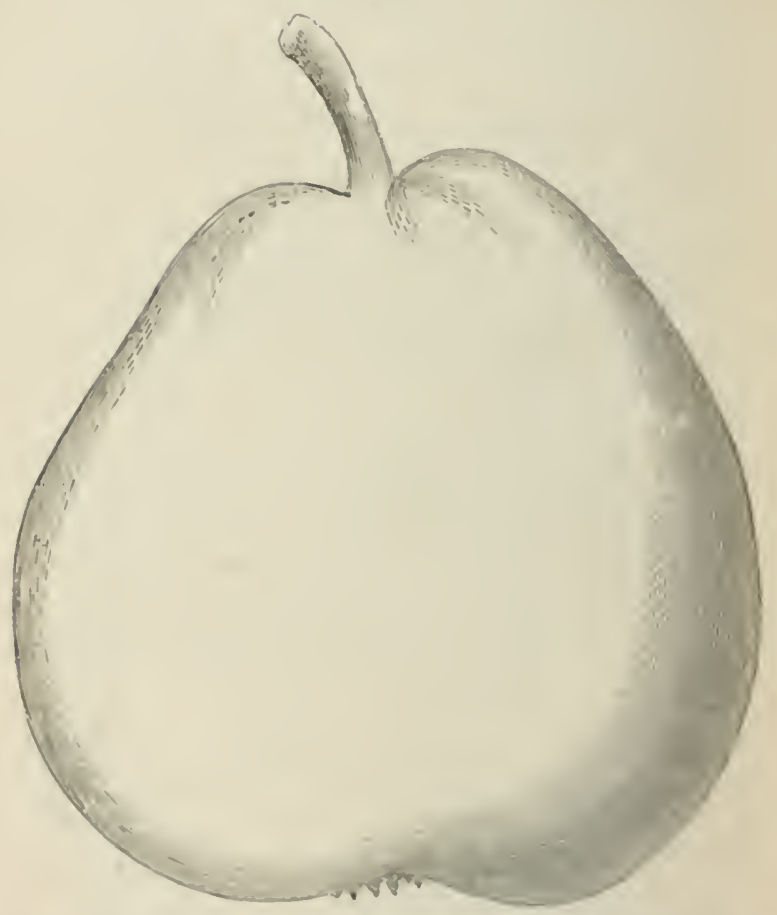

This variely, impurted from France by Wa. KexRlek in 1841, has attainet it high rank, and promises to fill, in some meastye, the enap caused by the finlure of the Verealicus.

It is a strong and healthy srower, but not one of the most vigoroun. It is, however, a most constant bearer, and very jroductive. It succects well on the (2unco: but its flavor is not much improved by it, as far as my expericuec extends; aud as it is an eurly hearer on the Pear, it is not of great advantago to grow it on the former. The fruit rescmbles the Pergalicu in form and color, acipuriur a 
bright lemon yellow, often with a fine blush. It is considerably larger than the Vergalieu.

The skin is somewhat rough, oecasionally; and the form often slightly irregular, like the Duchesse. Flesl, buttery, very juicy, and of high flavor; tcxture sometimes a little coarse.

Flemisil Beauty.

Foniante des liois.

Benrré des Bois.

Leurré spence.
Belle de Flanders.

Jerramotte de Flanicrs.

Inpuratrice de Erance.

LATE SEPTEMBEL TO MIDDLE OCTUBEL.

Fig. 73.

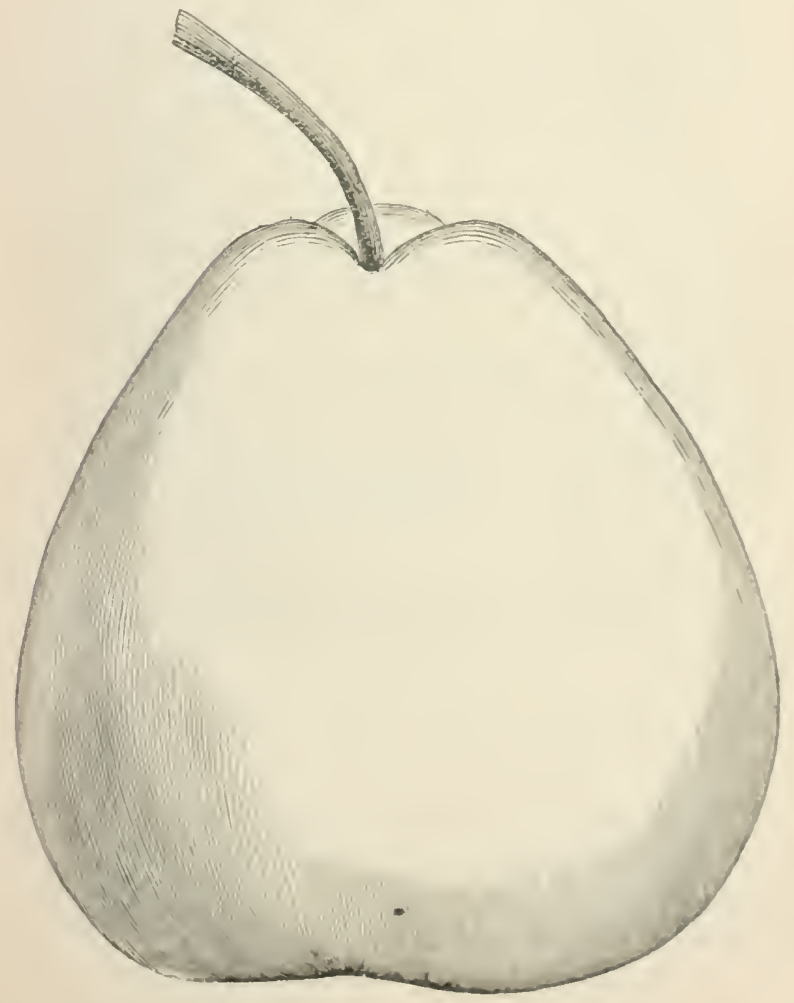


The merits of this variety are: a strong. luxuriant growth, beautitul shape, formins a pertect, but rather open, pyranid, whth but lutte slortening in : fruit of large size and fine slape, beanliful color, melting texture, rich loneyed flavor, perfuned aroma, and great abunlance of juiec-thus being one of the nost luscious amel agrecable of fruits.

It decays, however, soon after ripening, and camnot be left on the tree as loug as most others. It requires to be gathered beforo the stem will readily eleave from the spur, and while quite taste less and hard.

The fruit is very regularly obovate; skin, a dark grecu, changing to pale yellow on ome side, with often a crimson blush, and to rich russet on the other. Stem slender, about one inch loug set in very remular but shallow eavity. This varicty requires a good and deep soil, without which it is apt to be inferior, and slyy of bearing. Contrary to the experienee of some, I have found this varinty grows well on the Quinec, and I have none that excels it in luxuriance aud in beauty of sliape without pruning. It las not, lowever, reaclical an ase to sufficiently prove its productiveness.

This l'ear is a great farorite with pomologists. It oceupies a precuincut place at most horticultural cxhibitions. Specinens are often exlibited measuriug thirteen to fiteen inches in circumterence, weighing a pound and upwards: of great beauty of form aut color. The shape of this lear varies less than any other vitriety. Dr, Cirast, an eminent horticulturst, gathered from a tree, cight sears planted, 400 pears, which sold for $\$ 30$.

At the lixhlibition for 1857 , of the Massaclusetts Horticultural

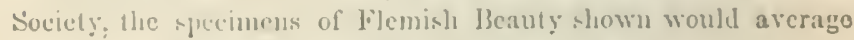
larger than thuse exhubited of the Duchesse d'Angouleme.

\footnotetext{
LAWREACE.

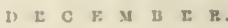

This is a nutive sarely, aul raths high with almost all cultivater. It uriginated on the Lawence liurm. Flushing, I. I., and is consulerel a hylorul of the St. Ciermain and Vergalicu. Tho tree is laardy, tolerably viuorous, landsomely shaped, and with a 
little pains in pruning, aequires a very regular conica. form. A characteristic of its growth is, that the branches grow nearly at

No. 74.

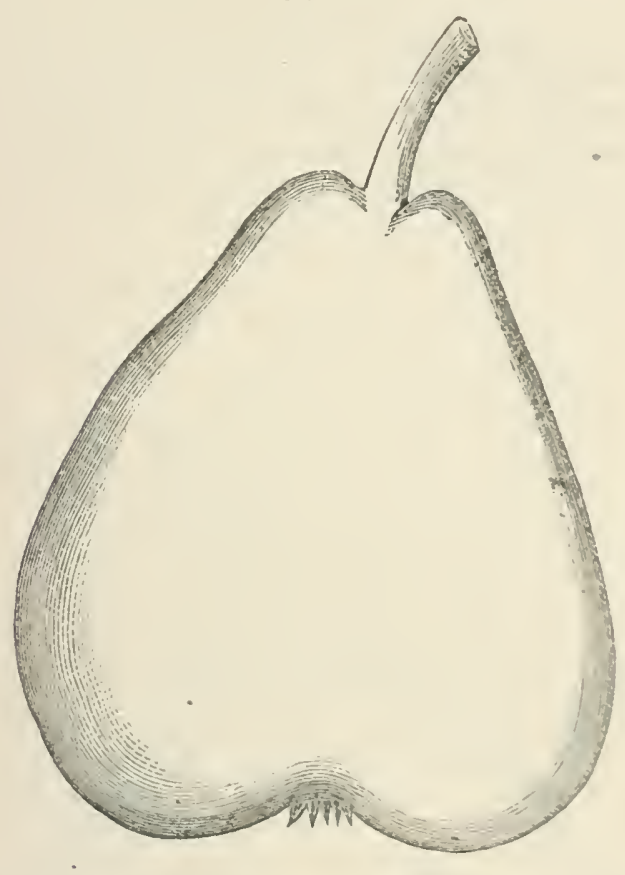

right angles to the stem, and often nearly opposite to each orher, giving an open head and regular shape. The wond is not stout, nor yet slender; it is of a pale brown with a slight yellowish shade, oceasionally armed with imperfect thorns. This variety is remarkably freo from discases and defeets. I have never kl:own an in. stanec of blight or of eracking of the bark, or of that obstinato refusal to bear sometimes met with in other kinds.

The fruit much resembles tho Vergalieu in size, and in appearance when ripe, though not quite so golden; but its rich, juicy, 
aromatic flavor, melting and buttery texture, rival that fanous pear in its perfection. It is peenliarly adapted either to late keeping or early ripeuing, according as it is differently treatedbeing capuble of being brought to perfection any time between Nor. 1 st and Mareh 1 st. This mueh iuereases its value as a market pear. It brings the highest prices, and is much sought for by fruit dealers. Mr. Joun D. Worfe and Mr. Jons H. FErRıs. of Throg's Neck, eultivate it in large yuautities; and wreat pertection, equaling the best Vergalicus in size, and some specimens muel excelling them.

\section{$\mathrm{SECKVI \text {. }}$}

FIABT BIPTEYBEI TO FIEST KOFEIBED.

This variety has won and retnined the highest popularity; in sulte of the inferior size of its fruit, its slow growth, and its tardiness in coming into bearing. It is the smallest of the pears that loold auy place in popular estecn, and tho trees on pearstueks, without extra treatment, are often fifiecn years in producing their first fruit.

No. 75

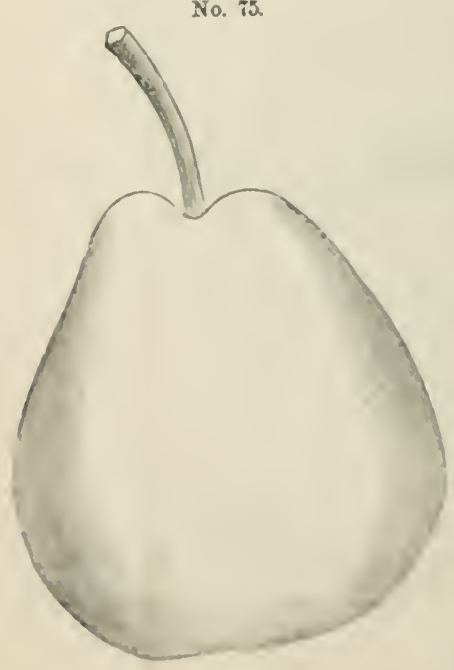

This variety originated near ['liladelphia, and was a clance seedling. Some European Pomologists have pronouneed it the most highly Aavored of all pears, in which upinion 1 by uo means eoneur. Its flaror is so sweet as to le sickening to many, and it laeks the highest essentials of sparklius. sprighty juice.

The tree is hardy, and every where free from blight, cven where all others are affected. It is trained to a pyranulal form masily, without much prominge. The wood is short-jointed, ratlier blout, 
of an olive brown. The fruit is obovate, brownish green at first, changing to a dull yellow; with a reddish russet cheek; stem nor very long; ealyx set in a very shallow basin. It has the merit of long keeping, while ripe, and unay be ripened any time during September and October. In collections, I would advise to plant at few Seckels on Quinec, for trial. It has a tendeney to overbear, when of considerable age, and; in consequenee; the fruit beeomes very small.

Winter Nelis.

Fonno de Malines. Nellis d'Hiver.

Culmar Nelis.

Beurri: de Malines.

$\mathrm{D} \mathrm{ECE}$ II $\mathrm{H} \mathrm{R}$.

Fig. 6 .

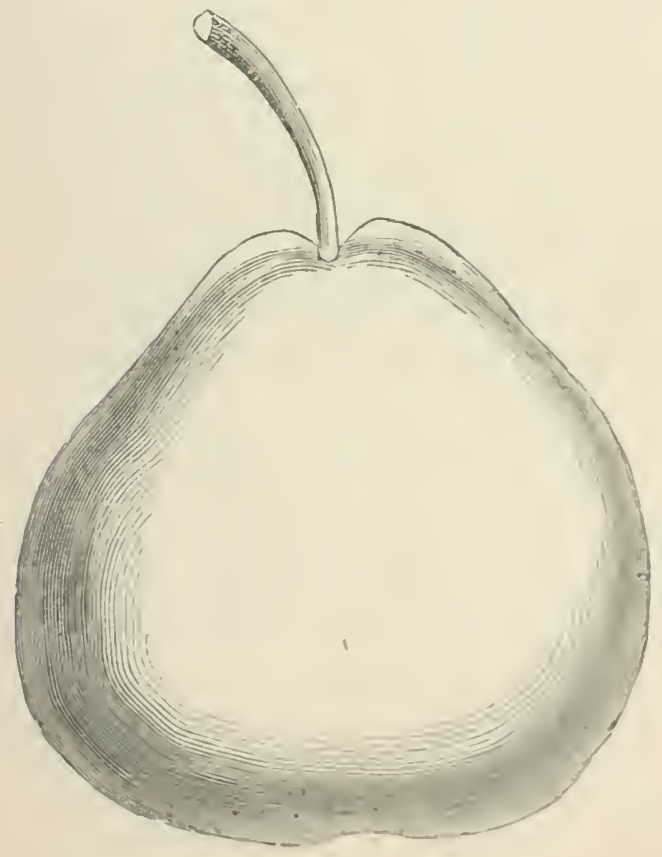


I am decidedly of the opinion that there is no Pear whieh execls this in all the good qualities of a fruit. There are but two defects, and these are not serious. Its appearance is uniuritine, nuch resembling a russet apple, and the tree is a straggling, irregular grower, its shoots being thin, twining, and sparsely set. Aecordingly, murserymen sometimes work it high up, on some free growing variety; to form standards; but I have found no difficulty in forming tolerably-shaped pyramids by sumıner pruning.

It is harily, with tough, elose-grained woot, emabling it to cndure extremes; is a moderately rapid grower, comes into bearing carly; and is very productive; has an open habit unless shortened in; leaves sinall; wood of a light yellowish brown.

It has been inuch condemned on the Ruinee, and I think some. what unjustly. I have found that, on this stock, it makes a vigorous growth, a very firm union, and fruits well.

The fruit is of medium size, and in the nost farorable conditions quite large; is of a light grayish russet; roundish, appleshaped; melting, buttery, sweet, high flarored, and very juiey. To obtain it of large size, the frut must be mueh thinned, as the tree is greatly inelined to overbearing. It grows in long elusters, resembling ropes of onions. It often ripens by the inidlle of November, but by eare in preservation, may be kept until Clirist. mas. This varicty, Mr. Dowixg says, holds the same rank among winter fruits that the Scekel does among the autumn. 


\section{VARIETIES TIIAT MLAY BL GROWN ON TILE QUINCE.}

Is the first glow of satisfaction with which Pomologists receired the announeenent that the much-coveted penr, which demanded the eare of two generations to witness its fruiting, could be grown sucessfully upon the Quinec, erery variety of pear was grown on every variety of quince, and the eansequence was, a disappointment-whose reflux, for a few years, secmed to threaten the very existence of quince-rooted pear trees, and cause their extermination.

It has now become fairly settled, that while all varieties of Pear will exist upon the quinec-root, but few will bear the test of the following rules, for growing the Pear upon that stock.

1. The variety must have such an affinity for the Quince, as to grow cqually well upon it and the pear-root-which ean only be known by extensive experiments, bj persons in different localities.

2. The sort of pear must be very cousiderably earlier in comiug into bearing than upon its own roots-in the case of the Bartlett, but little would be gaiued by its possessing an athinity with the Quince, as it is sufieicutly precocious in its fruiting to dwart the tree on its oพvา stock.

3. The Pear should be somewhat improved in size, flavor; and perhaps, in some varietics, in produetireuess.

When all of these conditions are fulfilled, it will be found that comparatively few varieties imperatively demand the quines-stock for their perfection. At the same time, almost all can be grown upon it, by complying with tho eonditions for their treatment, in planting; cultivation, and fruiting, riz.:

To bury the Quinee some inches below the surface.

To eultivate the gromul thoroughly, and supply sufficient nonrislment ; and

To earefully prevent werhearing when very young. 
BritiRI: D'ANJOU.

Nec Plus Meuris. | Ne Plus Menria

Yig. 7.

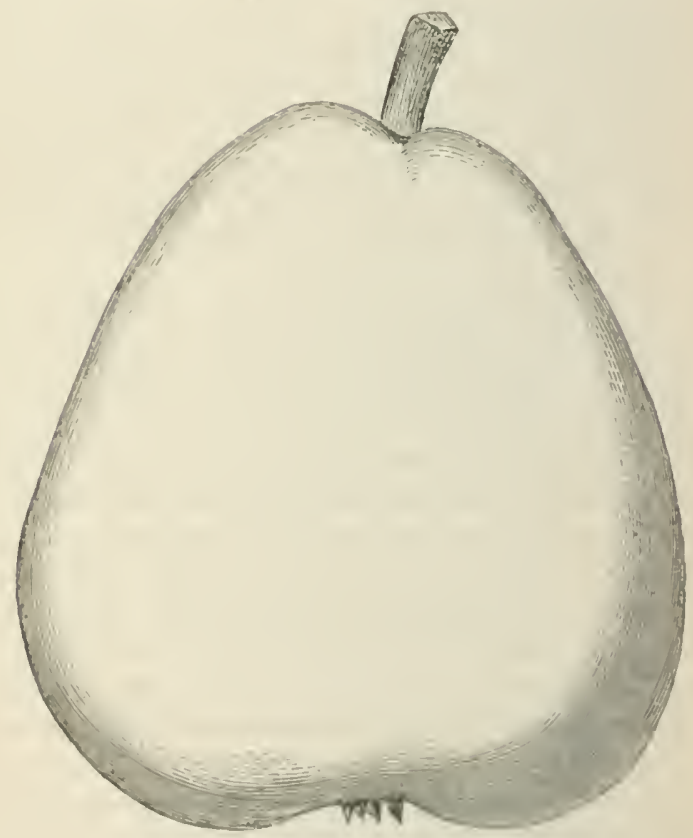

For this noble Pear, we are indebted to Col. Marsiall. P. Wiluen, who imported it from France. Notwithstanding the high claims made for it by him, it has not only met, but promises to exced our expectations of it. Nothing could be finer than the sight of the specimen trees, ten or twelve ycars old, in Col. WiLnen's ground, loaded with large and fair fruit, as I saw them in the fall of 1857.

$\mathrm{It}$ is a most prolific bearer, and, from its size, late kecping; and the hardy growth of the tree, promises to become one of the best market fruts. Its periud of ripening is usually assigned to Oeto- 
ber; but some specimens sent me by Mr. WILDER were sound, and not quite ripe, when cut on the 10th of Deember. I have, however, seen it ripen, for the most part, near the last of Oetober to the middlc of November.

The tree makes a peeuliarly stout, upright growth, the branches of a dark, purplish brown, starting out from the trunk at a considerable angle, but immediately growing upright, and presenting the appearance of being nearly parallel with the main stem. The fruit is roundish obovate, often considerably larger, upon one side, and curving to the other, with a short, straightish stem. The flesh is quite yellowish, buttery, and with a very rich, sprightly, sub-acid flavor. The pear must be marked best.

\section{Beurré Superfir.}

O C TOBE R-NOVEMBER.

The Beurre Superfin is a beautiful Pear, of large size, which, although comparativcly new, has received the unqualified approbation of all pomologists, as possessing all the nice requisites to cntitle it to rank as first-ratc. The trec is vigorous, and handsomely shaped, and quite early prolific on pear or quince-stock, and not liable to any of the serious qualifications which modify our praise of other varieties. The fruit, when fit for gathering, is of a deep pea-green, resembling the Glout Morceau; and though ordinarily ripe late in Oetober, with eare will keep to the first of Deember. When ripening, it changes to a rich yellow, and has the rather uncommon virtuc of remaining in a condition of exeellenec for several days after ripening. It is of the most buttery, melting texture, and the abundanec of rich, sugary juice, is a constant source of surprise. It is very regular and constant in its shape, of a slightly turbinate and oborate shape. This pear will undoubtedly attain a high popularity, to which the hardiness, productivencss, and beauty of the tree, and the cxcellence of the fruit, richly entitle it.

It originated at Angers, in the grounds of M. GovB.lLT. 


\section{Betrré Diel.}

Sieurre Tnzal, Jieurre Melon,

Beurri Magnitique.

lieurro liscumparible,

Buerro de Trois Tours,

Beurré Melondo do liups,
Celeste,

Dillon.

Jlorimond,

I) uruthece lioyal,

1)iel,

Gros Dillun.

Fig. 73

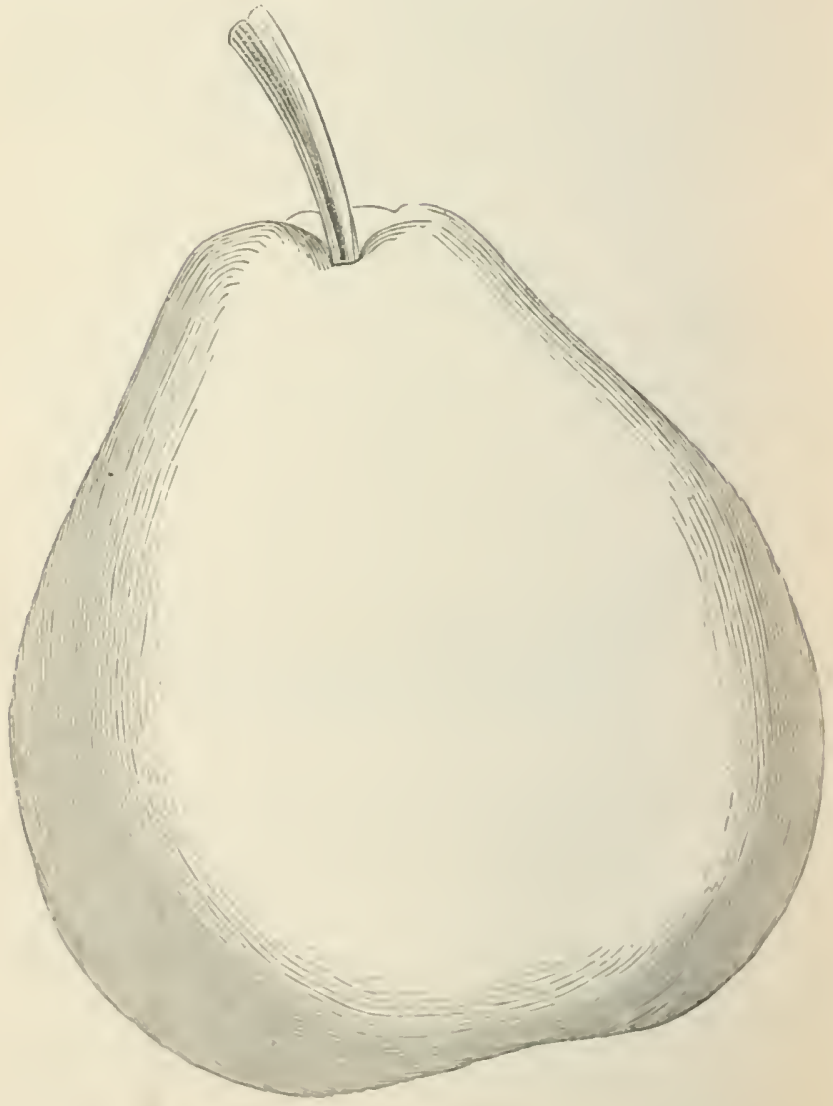


This noble Pear is one of the few hardy and prostable varieties produced by artificial cultivation or design. It is a seedling of $V_{A N}$ Moss, named in honor of his friend, Di. Dies, and will jireserte the memory of the latter longer than any act of lis own busy and honorable life. It is one of the most vigorous varieties in its growth, and is perfectly suceessful on the Quince; and like the Duchesse, its flaror is greatly improred by that stock. On pear-roots, or wlien grown on cold soils, or while the trecs are very young, the fruit is apt to be astringent and coarse ; and I have known cxcellent cultivators, unaware of its demands, to regraft the Diel trees with inferior varietics. While young, it is a shy bearer; and when in full bearing, the fruit is so regularly distributed through the tree that thinming is seldom necessary. The fruit is abundant in juice, of rich subacid flavor, half-melting, somewhat coarse-grained near the core. The skin is thick; and somewhat astringent, and should be remored before the fruit is caten. It is obtuse pyriform in shape, of a russet lcmon yellow; stem a little more than an inch long. Its period of ripening may be prolonged from 1st October to December by picking early, and packing in close boxes in dry, cool rooms. It needs more care in ripening than some others. The sloots are a dark brown, tinged with gray; inclined to twist with abrupt curves. Vigorous pruning is neeessary to produce well-shaped pyraınids.

In the grounds of Mr. Wixchester, of New Haven, trees of this variety, six or seven years old, which were models of beauty in shape, produced a crop of fruit in 1856, of which very few specimens weighed less than fourteen ounces, and a considerable num. ber more than a pound.

At one of the Massachnsetts Horicultural Exhibitions, Lwelve Beurró Diel Pears were shown which weighed fourtecn puunds; and Mr. Barry exhibited four of the same variety; raised in lowa, which weighed nearly five pounds. 


\author{
DUCHESEE D' $\Lambda$ NGOULENE. \\ Des liprrunals. \\ Rezenas. \\ FIIBT OCTOBER TO FIFTEEXTI NOVEMBER.
}

This peerless fruit inust be crowned as The Queen of Pears. Like its patroness, the daughter of the unfortunate Louis XVI., it was by narrow elhanees it escaped the axe. Near Angers, Mons. LE BAROX — one morning discovered his tenant engaged in digging around a fine thrifty pear tree-a chance secdling in a hedge-and on questioning; the Baron found it was for the purpose of exterminating it, root and branch. "This trec, Mons. Le Baros, for twenty years bears no fruit." "No matter," replicd Mous., " it is a good thing; to have eut those roots there; it will now bear fruit; fill up the trench, and we shall see." This rough rootpruning fulfilled the wise Baron's proplieey, and the sueceding summer saw it loaded with that queen of fruits. But though royal, the beautiful Pear was still unerowned.

One day; the daughter of Louis XVI., was to pass through Lyons, and its inhabitants deputed a Committee, of which our friend Mons. Le Roy was one, to receive her appropriately. Nine fair maidens presented the Duchesse with golden salvers, on which lay heaped the inore precious fruit, and begged her to bestow upon it her name-and tho pear now recognized as the erowning glory of all fruits, was theneeforward known as tho Duchesse d'Angouline. 'There are some who think the pear the more royal of the two.

It is by far the largest of table-fruits; of rich, aromatic flavor; meltinn, though tending to a coarse fibre, near the core, when badly grown and ripened. Very juicy, and kecping long after being sulfieiently ripe to eat.

The tree is somewhat tender in very eold winters where the thermoneter smks to $200^{\circ}$ or more below zero: but hardy and strong wouded, and very thrifty, stocky growth on solls of moderate fertulity; and prefers a rich, sandy loan to produce ils highest exeellence. Tho fruit is ofin coarse and tasteless on the penrstock: but both tree and fruit seem tho most completely fitted for 


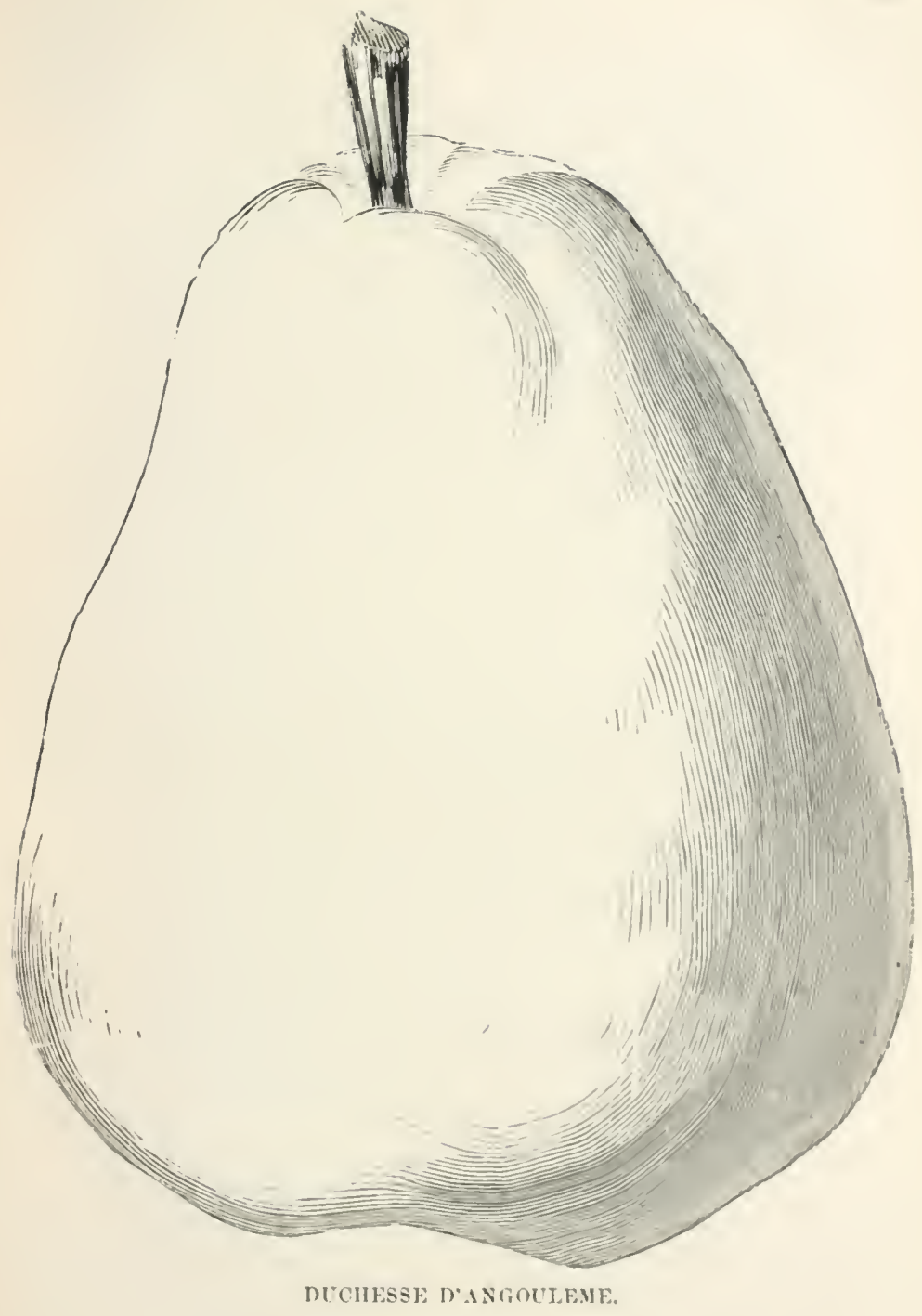



the quinee-stock of all pears. Grown on this, the size is vastly inereased, the flavor and texture improved, and the low structure prevents these great fruits from being blown off, while the bud unites with the quinee-stoek with so great firmness, that few trees of this variety ever fracture at the graft, and all seem to grow with as much vigor as on the pear stock. It must be said, however, that, like other royal personages, it does not produce great numbers of fruit, at least when young, though I have often seen on rich soils, trees loaded as heavily as any other variety. The fruit must be well thimned, the tree sererely pruned, and the soil rich. The wood is of a light yellow, tending to a reddish bloom on the sunny side of the young growth. The tree is not very regular in its sliape, but cndures severe pruning well.

Specimens of this Pear, weighing two pounds and a lialf, have been produced in California; and one whieh weighed two and a quarter pounds was raised by Dr. WARD, of Newark, N. J. It is one of the most profitable market varieties, the largest fruits selling from two shillings to a dollar each, in the shops of Broadway. I lave pieked Duchesse weighing twenty-one ounces, froin trees received from Franee in the preceding spring, or seven months previously. 
Easter Betrré.

Dovenn i diver, Belle d'l xelles,

berg. du la l'enticute,
Doyenue de l'riniemps Seigneur dillis r,

Vinter Beurre,

YA R C II A NDAFRIL.

Fir. 79.

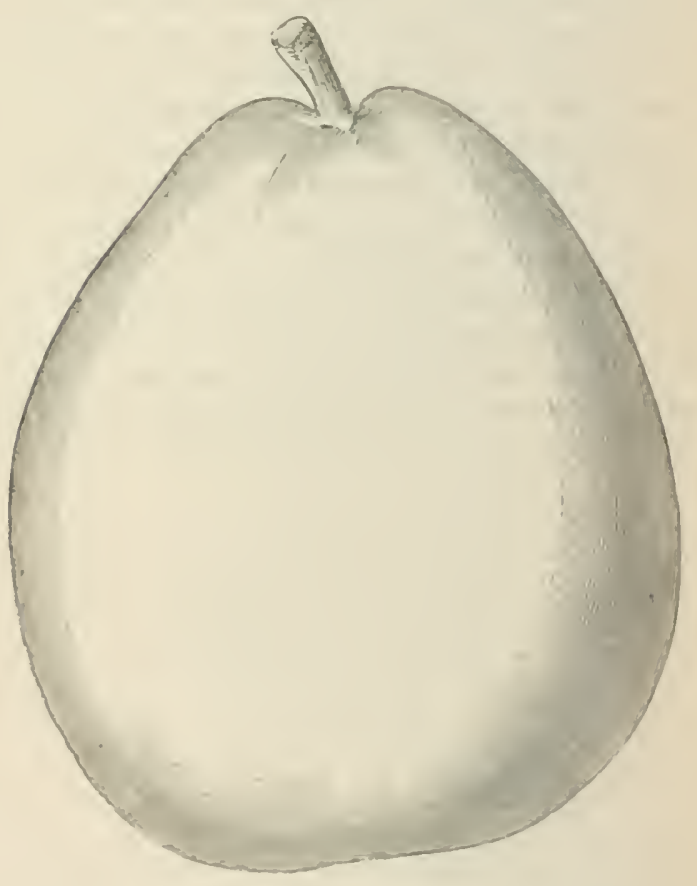

This late kecping, but rather meonstant fruit, has of late years received extraordinary attention. It is imported in considerable quantities every spring by the fruit-sellers, who obtain in March and $\Lambda$ pril cnorinous prices for it. It has thus far proved eguit, 
uncertain in this country, but as far as 1 ean learn, its failure is the result of neglect of thinning and improper treatment in ripening. The Freneh greatly execl us in both these processes, and the imported pears of this variety are almost invariably fine.

It should be understood and remembered that winter pears must acquire a stock of more concentrated juice than the autumn os summer raricties; the sap must be rieler in the sugar-producing prineiple, and if more fruit is left on the tree than the roots and leaves ean supply with the neecsary elements, the consequence is apparent. Second, that all the juice contained in the fruit at the time of pieking, is necessary to complete the chemieal change of ripening, so that, in proportion as the fruit loses its water, its dry elements lose their power of uniting and producing a high flaror. From these faets, it will be perecived, that unless all the juice of a winter pear is preserved by artifieial means, it will be impossible to ripen it with any degree of execllenee, although the fruit is medium sized, seldom reaching ten ounees. It has been sold in New York as high as twelve dollars a dozen; but the more ordinary price for good specimens is three dollars per dozen. Its flesh is white, and very juicy, buttery, and melting: when well ripened. It is obtuse pyriform, often a little flattened, dark green, sometimes reddened on the check, and aequiring but a faint yellow in ripening. It requires a longer scason than that of the Eastern States to eome to highest perfection. Its season is March and April; oceasionally May and June. The tree is a hardy: vigorous grower: bark, a peculiar reddish brown; shoots, stoeky; tending to upright growth. It is well adapted to the Quinec, on which it malies a strong growth, with much improved fruit.

My recent experience is, that the Doyenné d'Alençon and Benrré d'Hiver Nouveau will prove greatly superior to this for general enltiration. But it is too early to speali decisively. 


\section{Glout Morchal.}

Sluut Morcenu, Colmar d'lliver,
Beurré d'llardenpont, beurré d'Aremberğ (erroneously).

\section{DEOEABER TO JAXUART.}

Fig. 80.

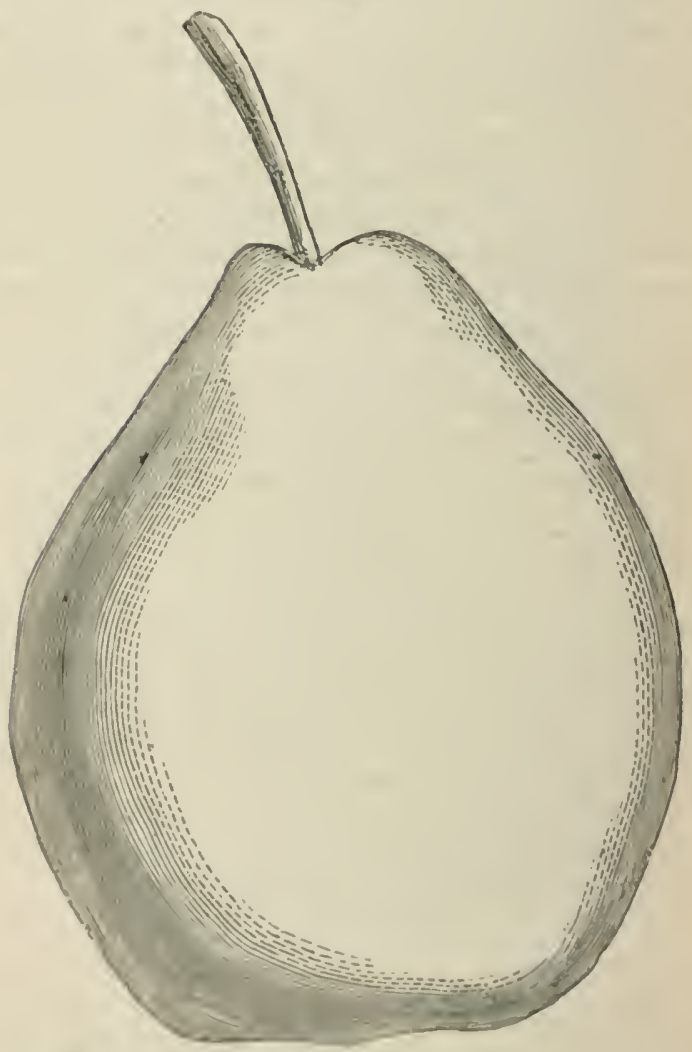

This excellent pear is of Flemish origin, its name signifying "grecly morscl," and though plain and unattractive in appear- 
ance, its nobler qualities make it a favorite whenever grown. Its reputation has sometines suffered by being eonfounded wrth the Beurré d'Aremberg, a very inferior and dissimilar variety. I have often received it from France under the latter name. The d'Aremberg is feeble and tender in growth; shoots starting at acute angles from the stem, growing upright, of a light reddish tinge, and on the Quince, the growth is still poorer, and the union imperfect and feeble. Its fruit is of pyramidal shape, stem short, stout, flesliy, a little curved, size seldom half that of the Glout Morceau. Color quite yellow, even while hard and on the tree. But the Glout Moreeau is in every particular dissimilar, but in no respect more so than in the growth and vigor of the tree, which is a very vigorous grower, making a handsome pyramid; and though said to be somewhat subject to the blight, has not proved so on the quinee stock. The wood is of a light brown, elouded with a grayish tinge. It is not very prolific, while young, but quite so, when more advaneed, the fruit being uniformly of good size. It is peculiarly adapted to the Quince, the growth being equal to that on the Pear, and the fruit much improved. The fruit is of a deep pea-green, until it matures, when it becomes of a greenish yellow, with pateles of brown russet. The fruit lias a rich, sugary perfumed flavor, is melting and buttery, and keeps late, flesh colorless and fine-grained.

In the fall of $185 \%$, I saw in the garden of Mr. VAs Dise, at Cambridge, Mass, a tree of this variety, on which, it was estimated. were growing from eighty to one liundred dozen of nine pears, such as Mr. VAN Dixe had for several years sold in Boston for two and three dollars per dozen. The tree is very tardy in bearing; and is, therefore, one of those varicties for which the quinec-stock is peculiarly valuable. 
218 FOI MARKET CLLTMATION-ON OQUNCE.

Lovise Boyse de Jersey.

Loulse Bonne d'Arranches,

Bonno Loulso d'Arrancbes william the Fonrth.

Fig. $\$ 1$.

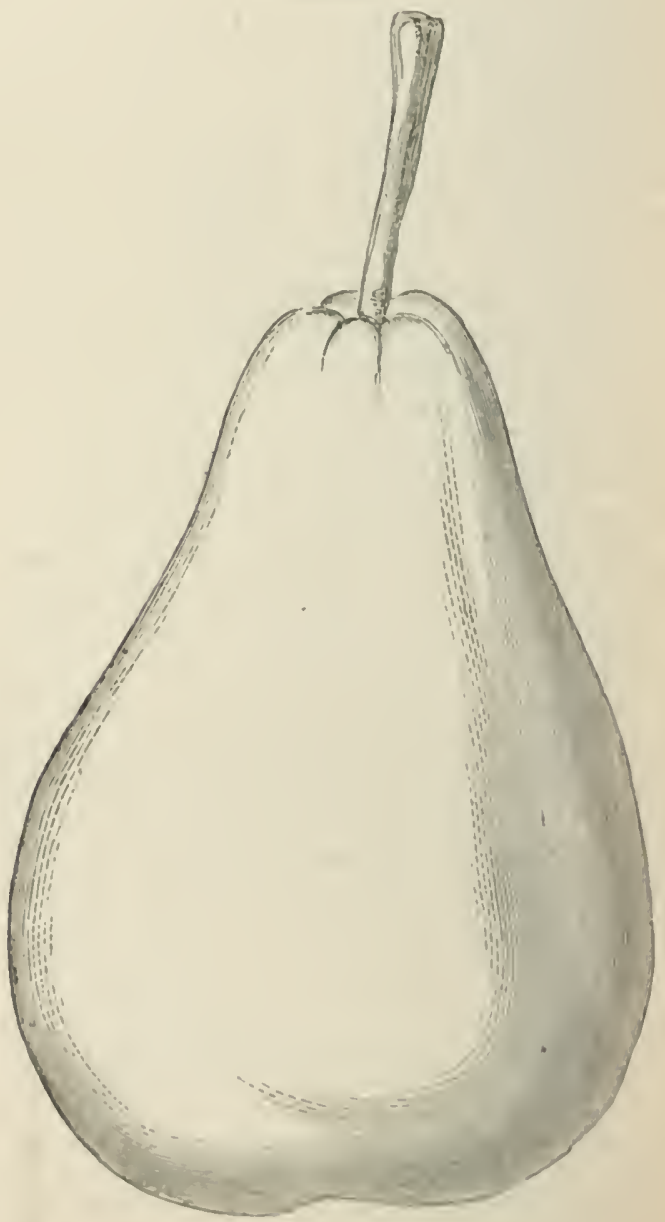


Some diserepaney of the anthorities in regard to the names of this varictw, have produed a little embarrassment. II. CAPPE pronounces the Louise Bonne d'Arranches quite distinct, in which decision Mr. Downing, in an account of his visit to Paris, coincided; but in his fruit-book he gires the names as synonyms.

It is a native of the Isle of Jersey, where it is produced in higher exeellenee than clsewhere.

It has an upright habit of growth, is easily distinguished by its dark purplish shoots, a little fleeked with light grayish spots. On the Quinee, it is an abundant and early bearer, and its flavor is much improved on that stock. When, however, the trees of this variety on the pear-stoek have attained considerable age, there does not seem to be mueh differenee in quality between the fruits grown on both stocks. When it is allowed to fruit too hearily; or when grown on very young trees on pear-stocks, there is a tendeney to astringency, especially in the skin. On the Quinee, it does not readily talic the pyramid form, its prolific nature crowding the wood-buds into fruit-buds, causing a deficieney of branclies. To fill out the eone, it must be more heavily eut baek than other kinds, to foree the dormant buds to push, and form radial branches. The fruit should be very much thinned, as much more will set than can be perfected.

The fruit should be pielied as soon as the stem will cleave without breaking, as its astringeney is increased by ripening on the tree. This jear is the most abundant in sprightly; subacid, champagne-flavored juice, of all pears. Its thick skin materially serves to retain this juice, retarding evaporation: and although considered by some an objection, it is essential in preserving the excellenee of the fruit. The fruit is often of a beautiful erimson color on the sunny side. 


\section{Vic.Il of WINKFIELI).}

Cure,

Non-icur le Cure. belle do l3erri,
Comice de l'vulu:n,

lielle Alrienne,

bello lleloise Clion.

D E C E N B E R.

While this fruit bas few of the high qualitics that amaleurs now require from a pear, to place it in the first rank, it has still such valuable properties that it must receive attention. As a marliet fruit, there is none which, I think, when all its qualifieations are taken into consideration, will have a higher value. Tho tree is very liardy; and probably the most vigorous grower of all pears, making very stout, eurving, and stocky shoots. It comes quite early into bearing, and has the uneommon fault of maturing twice the number of fruits which the tree should bear, without much lessening the quantity borne in suceeding years, or cheeking cntirely its growth. When the fruit is thinned to one-fourth, or one-lialf, the pears reach a very large size, and are much improved in flavor; but when small, the fruit is astringent, hard, and seldom ripening so as to be eatable. The first requisites in the treatment of this fruit are, thinning to the number which will become full grown, and continuing it upon the tree as late as safely from frosts will allow. Mr. Sanuel WaLker and Col. Wirder esteem this fruit so highly, that they were heard to say, many years ago, that should they be confuned in their ehoice to a single variely, they would strongly incline to select the Vicar; and at the last P'omological Convention, stated that their more recent experience confirmed their carlier belief. Its ltardiness, great vigor, early prolitie, and constant bearing-its large size, fine sliape, rich color, and late kecping, overcome the scrious objections to it which would condemn any nther fruit. It is never melting, nor high flavored, though richly perfumed, is often astringent when not well grown, and when eaten too ripe, is mealy and dry. But when just ripe, it is erisp and tender, with an over-abundance of juice, of a pleasant acid flavor, which is particularly grateful, as being enjoyed during tho seuson when antumn fruits are long gone, and winter fruits not yet ripened. But it is absolutely necessary that the following 


$$
j
$$


enulitums must le fulfilled. Jarge size must be obtaincd ly thimmug. tw concentrate the saceliarine matter of the tree into few frums: tle pears should te allowed to haun late ou the tree; slinuld lic at unce removed to a enol rooun; slould be brought out but tew at once to ripen, and should always be caten befure becoming suticiently soft to be casily indented by the thumb and finger.

Mr. Wususu Inwe; of Westeliester County; has execlled most whers in the production of this pear. I received from him. in the Fall of 1S.5f. Viears weighing seventecn ounces, and of beantiful shape nul color. liut these were far excelled by a specimen recoived from Oregon. which weighed twenty-cight otmens. A trec of this varicty; five years planted, from the utursery row, erown by l'rof. Maprs, was cxhibited at the Amcrican lustitute Fair, bearing onc liundred and seventy fair-sized pears. lar too many to arrive at the highest perfection. The fruit is larese, curval pyriform, will ncek much clongated, and continuel up upon the stem, which is curred, and has flesh around its base.

When placed in the sun; a day or two before ripening, it aequires a rich golilen or lcmon-yellow color. It is greatly improved by growing on the Quince, on which it makes a strong, vigorous growth; and a firm union, and proving most perfectly adapted to it iu every respect. On elecp alluvial, or riclı and damp clay soils, it is somewhat subject to blight.

UriBa:ISTE.

Pevrre Piquery,
Louiso dirleais

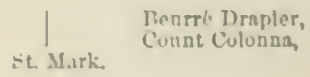

O О TOB

fohs excellent nul beautiful pear is a fiborite wherever it has

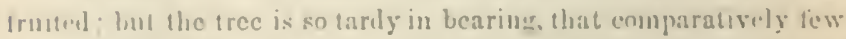
lave proved its exeellence. The natural beanty of the iree is umequalled, us it takes n stout jyramidal shape wuth searcely auy prunine. Ahe cone being rapilly filled out with numerous brauches lloat d erilne a graceful curve. Tho hardiness and tardy bearing of the treo grive jromise to it of great lonecvity. 'The fruit is but little ahove the raedum size; but its great excellenec and frechom 
from disease or blemish entitle it to the highest rank. It is so tardy in bearing upon the pear-stoek, that it would be a misfortune if it had proved unfitted for the Quinee. It makes a firm union and vigorous growth upon that stock, and bears eight or ten years earlier than on pear-roots.

Fig. 83.

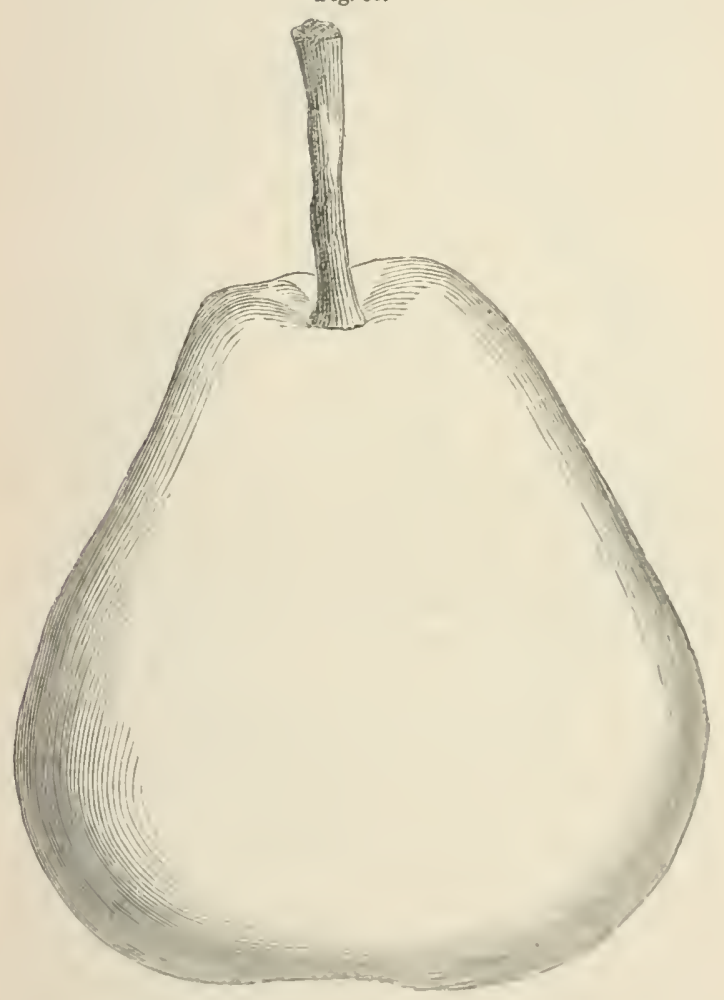

Col. Witder says, that he has trees of this variety on both sloeks, twenty feet in height, planted twenty years; and that while those on quinec-roots have vorno twelve years, those on 
pear-stock liw scarcely produced a speetmen frutt. From each of thr e on y func. two or three bushels of pears have been gathered

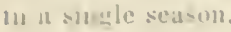

The frum is telieious in llavor, lighly perfumed, inelting, aud whlout any of those seruous fimlts prosessed ly some varioties, stels as rutumg at the core, criclinge or easkering. The pear is viry mnoull, often glussy, rupening to a pale, greenish yellow,

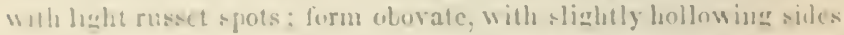
mar the neek. It is very broad at the calyx ead in grojortion. with a whle, deep Lassug, sem long. and set in a deep lubluw

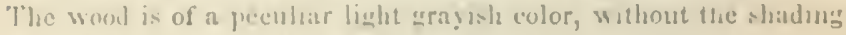
or tiutmg of other varictue; on the summe side.

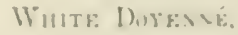

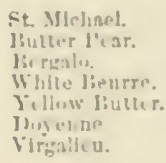

St. Mrlinel.

Jutler l'tar.

Jis renlo.

Jillus: liubler.

Jing en ne

It is with sume hesitation 1 adnit this in the list: but us great cxcellenee. abundant ("ups. and the hardiuess of the tree, enmpel me to allow it a place. hut wilh the sad qualitication that it cannut be frumed in perfection. with any tolerable certamy, any

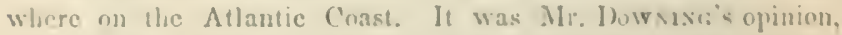
that its falure was the result of the exhanstion of the alkalune

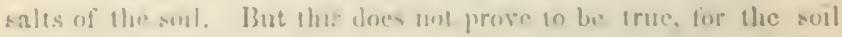

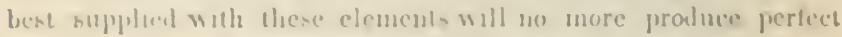
Verabans than the jonrest soll. The tree erows vizorously,

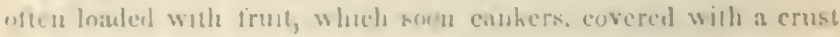
Jhe lasut leather, erachus into irregular fissures, beeming loblally unfit (o) ('at.

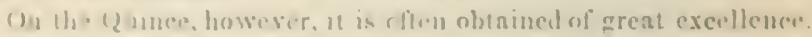

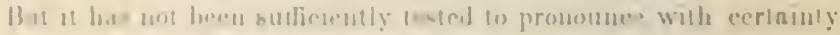

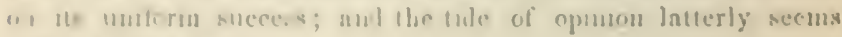

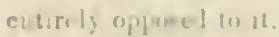

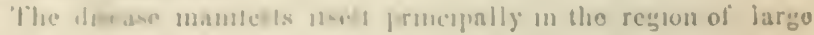

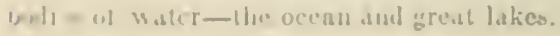


White. Dorexné.

Flgo. 84.

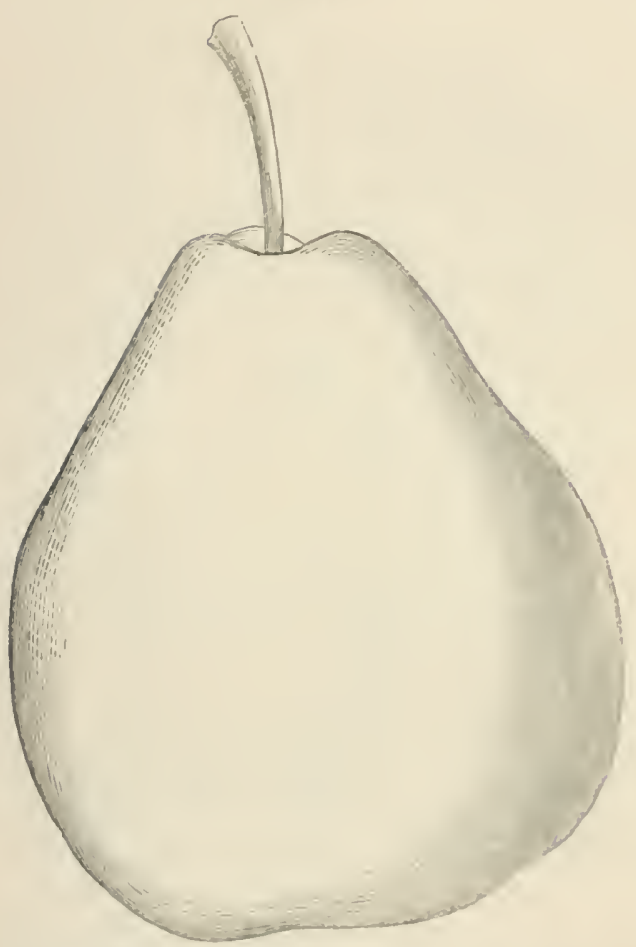

This fruit searecly necls a description-it is of mediun size oblong obovate, becoming golden yellow in ripening, with a rien blush on one elicek. It is the very type by which all other pears are compared in its melting, buttery texture, and abundant spiced and high-flavored juice.

The tree is vigorous, of rather upright growth: the yearling sloots of a ycllowish east, with a pale blush on smmy side; the older wood, of a slight reddish glow:

There are ming scedlings of this raricty that approach it in execllence. 


\section{A I D I'TIONAL L I S'T'}

Tus second selection of pears is intended to include those havine mo:t of the properties requisite for the first list, but which are deficient in some important particular. Some are too new to be pronouncel upon; some are equal to those of the first list in eertain localities, but not in all; and generally; they possess too great cxecllenee of flavor, sizc, and beauty, to be passed over.

They are all necessary to a complete amateur collection, and the market-fruit raiser slionld have at least specimens of every lind, to test their fituess for his locality. Any of these varictics may be pronouncen best, when the entivator has the soil and climate which bring them to them highest perfection. aut they suffer no disnaragement by being plaed in this list; for they unay, in localities alapted to them, prove superior to any in the first list. It must be remembered that this selection is made more aceording to a markcunan's calculations of profit and loss, than an amateur's cuthusinstic admiration.

Vitricties proved to be adipted to the Quinec, will be noted in the deseriptions. Where nothing is stated in regard to the stock, it may be understool that the pear-stock is best for that variety, or that it is not suffieiently tested on the Quinee.

A.nI:

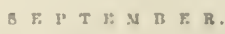

An exeellent variety, as far as I have secn, proving a most hardy tree, a reguiar and early bearer. 'The fruit is said to rot oeca-imally at the core; I have never foumb it to in so. Aecording to Mr. Duwsins, it urver suffers from blight, and I believe docs not on most solls. A larae number receivel ly une from a nursery located on at low, allurial solit-in fact, a drained mill-pond bedblishted badly. Some of my friends who havo planted it, are lisappointed in its thavor and gencral eharacter. The fruit is loug 
pyriform, shaped somewhat like the Bartlett, but smaller; with a yellowish green and reddish tinge on the check. Very juicy, melting, with a delicious sparkling flavor.

\section{AxaNas D’Eté.}

SETTEMBE $\triangle$ IX OCTOBER.

Fruit excellent, fine grained, buttery, melting, from medium size to large; abundant sugary juice, of rich flavor, and perfumed when perfect. Skin rough, coarse, - yellowish green, with large russet rougliness flecked over it. Shape pyriform, tapering quite regularly to the stem, which is set without depression, is straight, and is of medium lengtlı. The fruit is very variable, and sometimes quite poor. lipens in September and Oetober, thongh terined by the French Summer Pineapple.
Fig. \&5.

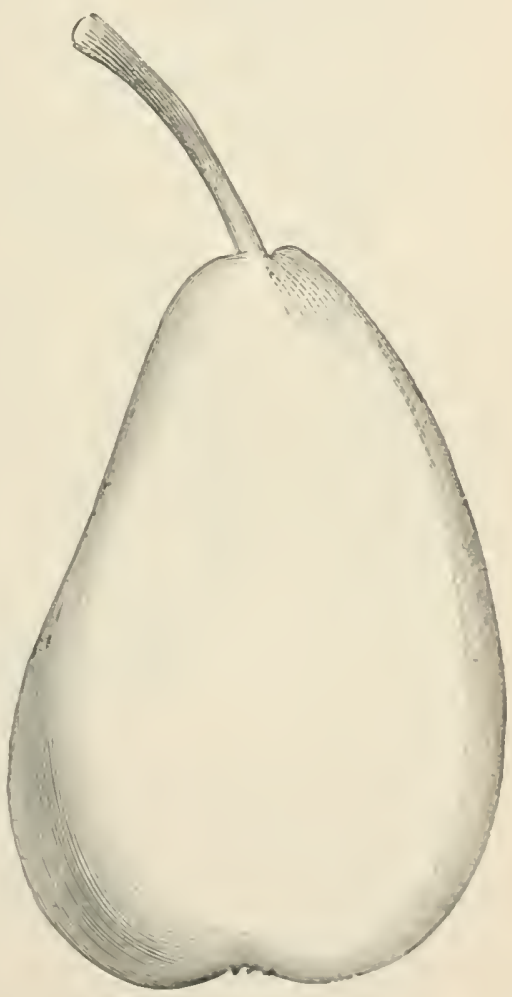




\section{Brurré Gris dilivel Nouveau.}

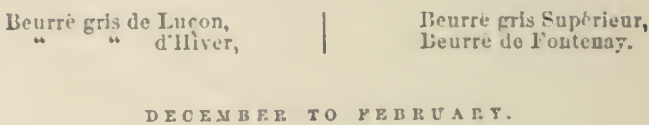

This pear will be highly apprectated when better known, being one of the most sitgary, juicy; melting, and buttery of winter pears; much resembles the Wiuter NelisintexIure and flavor. but is more sparkling and juicy. Fruit froin inedium size to large, obovate: slightly depressed on one side, an 1 hollow on the other. Stem stout and thick. skin, rouwh Eolden russet, often with a liandsome blush, dotted with russet sppots. This pear is the largest Fig. 80.

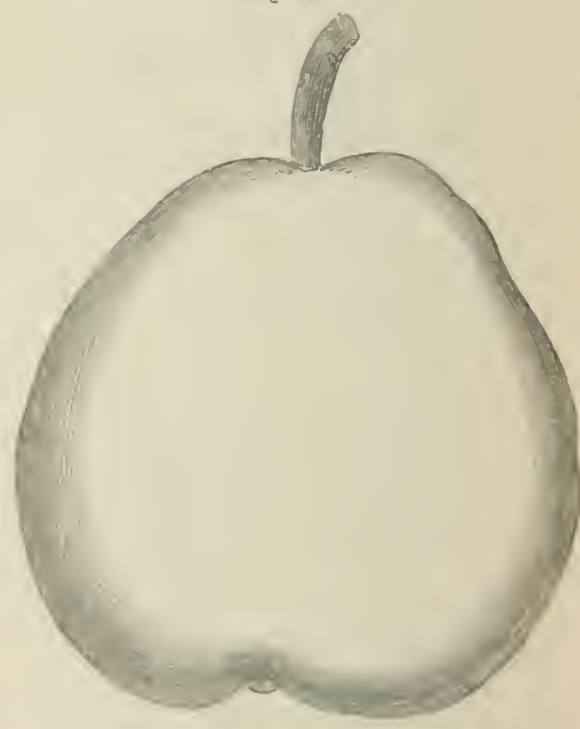
and handsomest of the russets. Tree moderately vigorous, very productire, with dark brown, almost reddish wood: promises well on the Quinee. Its late keeping - December to February - its ripening without tho constant varinbility of the kaster Beurrí, and other winter varieties, will "rive it a high reputation. 
Beurré St. Nicholas.

Duchesse dorleans. I St. Nicholas.

DECEUBER TO JANUAEY.

Is plaeed in the highest rank by all who have fruited it. Very juicy, melting, with a high, and rather aromatic flavor. Obovate pyriforn, swollen at the centre, medium size to large; light yellowish green, and occasinnally a bluslı dotted with brown. Stem long, stoutish, eurved, with fleshy insertion. It has grown well with me on the Quince, and makes a liandsome pyramid. Ripens in September and early November.

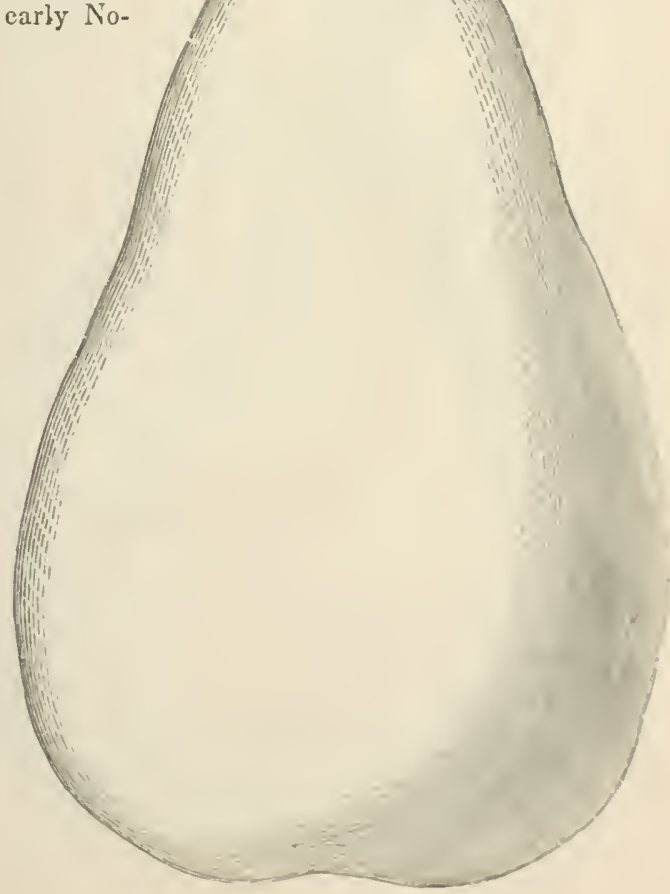


[B.C'KRÉ D'AKEMBERG.

Duc d'Aremberg.

L. Urpheline.

Deschaupa.
Orpbeline a'Fngheen.

Ievero d'( Trphelines.

Coluar Descbaujs.

FE I I U A II $\mathrm{I}$.

I intended to place the Beurré d'Aremberg upon tho list of rejected varieties, but in deferenec to the Ameriean Ponological Society, I gire it here a deseription. This name has been often erroneously applied to the Glout Morceau. The high claims made by the friends of this variety havo not proved well founded: it

Flg. 83.

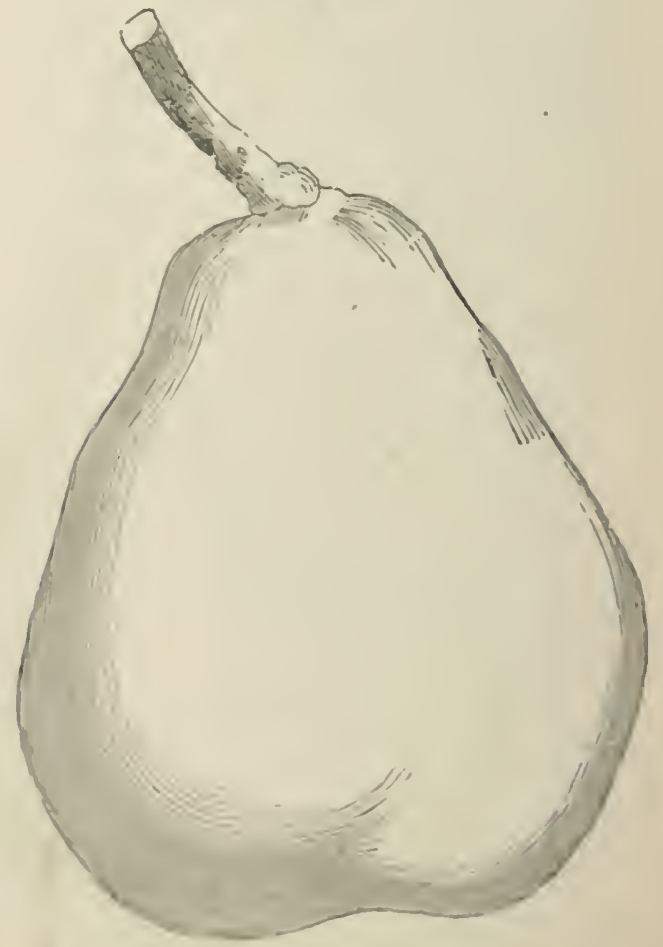


being short-lived, eankerous, and unwholesome on the Quince, very difficult to ripen, often woody and astringent; fruits early; of fair size and color, keeps like a black walnut, and tastes like one eaten -lıusk and all. Stem thick, irregular, fleshy; declined. Fruit obovate, short pyriform; said by some to be "good," cven " best." But it camnot be recomended for general culture.

\section{Betrré J'Auhlis.}

OCTOBER.

Large, productive, fine flavored, often as good as the Bartlett. Tree a prodigious rampant grower, difficult of restraint. The fruit lias the defeet of never attaining nore than a dun, dusky yellowish green, sometimes with a faint blush, and is far from attractive in appearance. Flesh yellowish, often somewhat coarse, must be eaten immediately on rip. eniug, soon becoming mealy and insipid. Shape, short obovate, inclined to irregular turbinate. Stem long, oblique, enlyx open, basin shallow

Fig. 89.

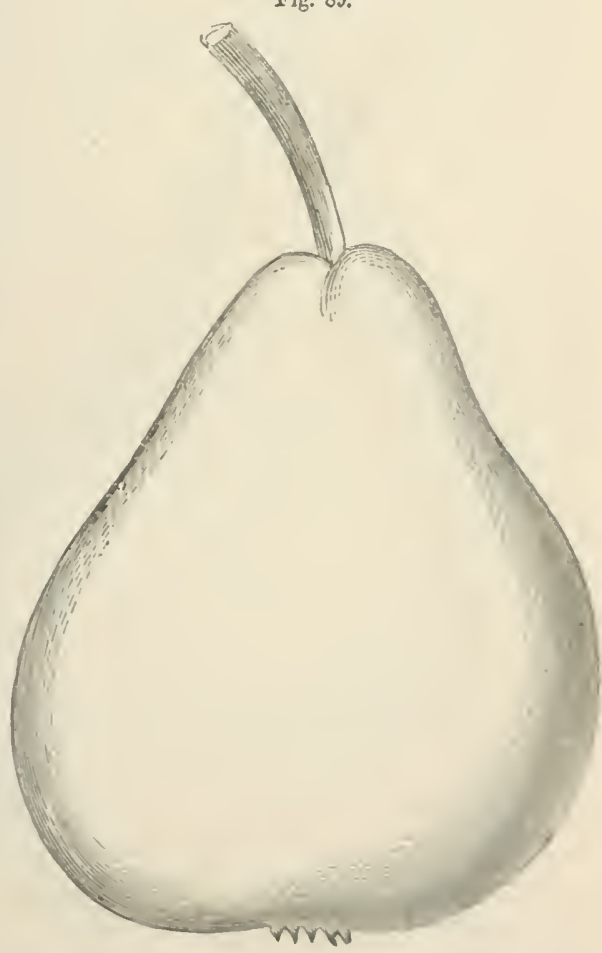


Betraké Bosc.

liuse"s Ifuschenbirne.

XUVEM HE IS.

Flg. 90.

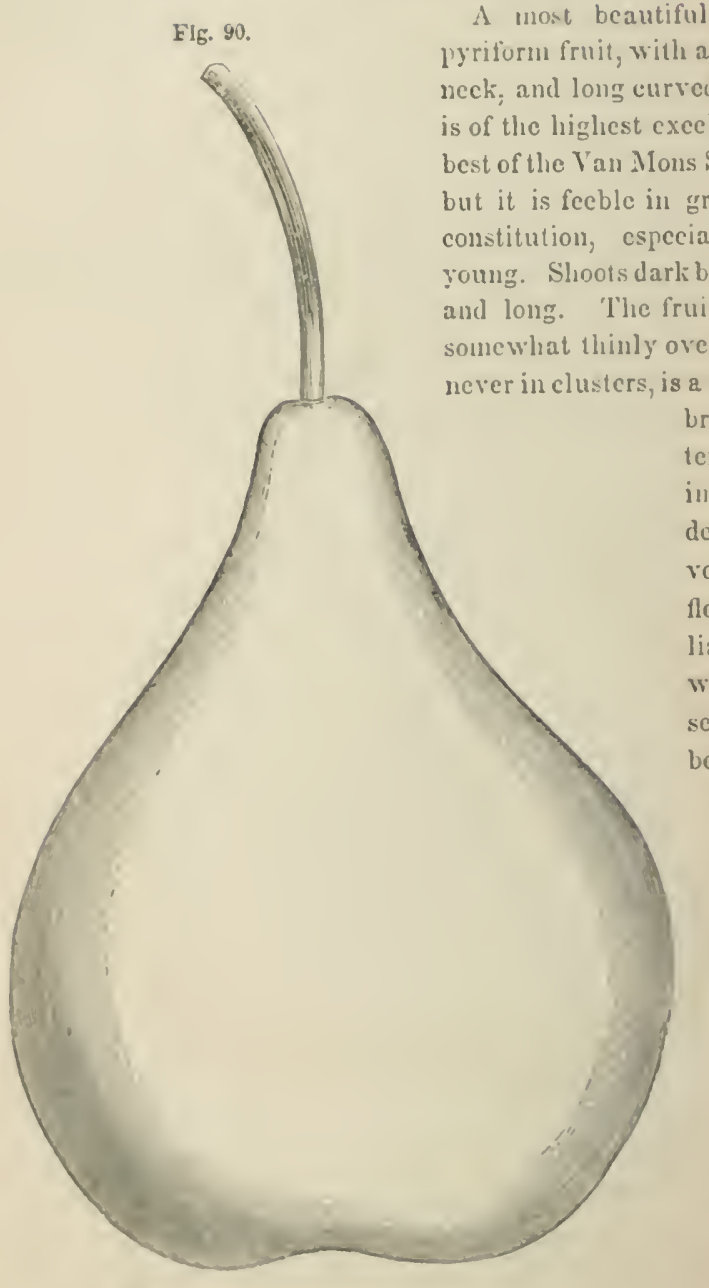

A most beautiful, tapering pyriform fruit, with a thim, long neck; and long carved stem. It llenee, the but it is fecble in growth and constitution, especially wlien young. Slioots dark brown, thin long. is borne somewhat thinly over the tree, brown, buttery, meltiug, of most deliciousflavor, white flesh, peeuliar sliape, which once secu, camnot be mistaken 
Beurré Laxgelier.

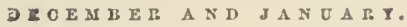

Fig. 91 .

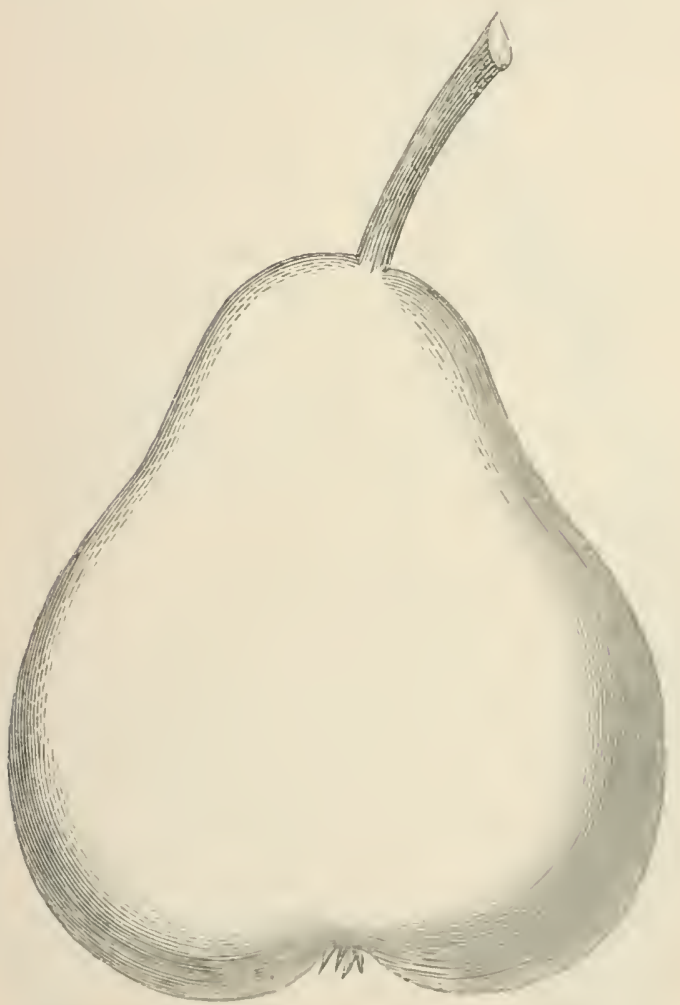

$\Lambda$ new rariety, which I have not thoronghly tested: but so esteemed by the older pomologiste, that it must receive a place in this list. Fruit medium size, somewhat irregular obovate pyriform, tending to turbinate, contracting near tho neek like Noureau 
l'oiteau. Stem stout, rather long, set without depression on tho obsure end w the pear. Basin otten furrowed; ealyx sct deen in it. Coler lively green, ehanging to pale yellow in ripening, wh reddush blush, and russet dots. Flesh yellowish white, and when well ripened, melting with abunditut, rich, sprightly, subaceid juice Gool on l'ear, somewhat better on Quince. Trec vigorous and productwe. Scason during December and Jamuary.

\section{BF: MUÉ Captacnont.}

Cafisument.

1 Aurora lieurre.

This pear descrves a place in this list, not so much from the quality of its fruit as from the great hardiness, productiveness, and beaty of the tree. It is a vigorous grower. Fruit melim sizc, very regular, long turbinate, tapering insensibly into the stem, which is long, thin, and eurved. Quite sweet, melting, buttery, fine-grained and high flavored, but ofien astringent, its quality being quite variable. Skin smooth, elear yellow; with russet red clicek.

Barrri: Cratrgant.

NOF M R R TU JAXUARr.

This most moble and beantiful pear disappointed the too sanguine expectations that altended its first introduction; but the reaction wall turu in its fovor. and at will he farly appreciated. The fruit Is rafluer coarse in texture, and not always of high thavor; flesh yellowish, aud, when quite in perfection, buttery, jucy; wuh a pleasant, ferfumed flavor. and rather granular texture. It is large, pyritorm, obtuke, one-sided, keeps well; is good ou Qunec, and wll ecrtamly prove a valualule market fruit. Trec bears as early as the Bartlett; wood much rescmbling it.

It if errtably one of the most gorenens of frums, coloring with

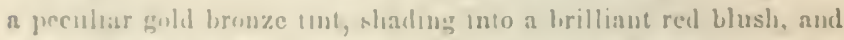
when borue, as often weeurs, upout trees unly two or three years from the bod, und nequiring a sto even larger than in the cut, presents a strikingly beautiful appearance. The Clairgean ripens 


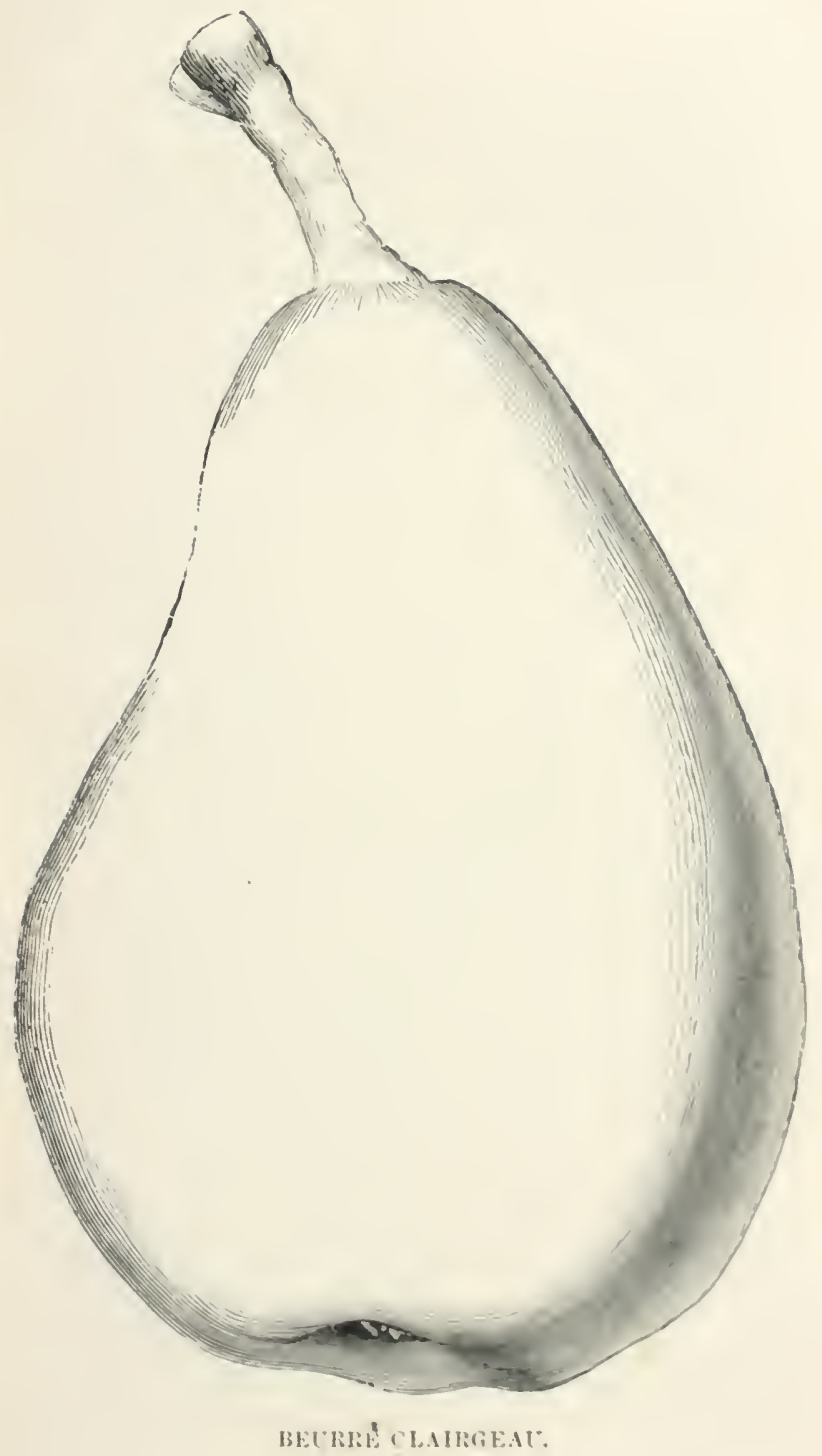



with a peculiarity which is wortly of notice. While most fine pear's lose greatly in quality by over-ripening, beeoming rotten at the eore, insipid, or mealy, the flavor of this pear is muels inproved when apparently verging on decay. Indeed, when a considerablo portion of the exterior has decayed, the interior will be sound, and retain its flavor, a quality that will not be despised by those who have ripened the core-rotting pears.

Beurré Giffard.

MIDDLE OF $\triangle U G U$ GT.

In quality and size, this beautiful pear ranks lighest among the August varieties. It approaches nearest the standard of buttery, melting, juicy, and ligh flavored pears. But on the other hand, the tree is of fecble and straggling growth; growing not more than half as rapidly as most others. It is of a peculiar reddisll tinge, branc'ing at obtuse angles. Fruit a litlle larger than medium, pyriform or long turbinate; stem and fruit merging insensibly. Skin yellow, when ripe, with a red flush, often appearing mottled.
Fig. 92.

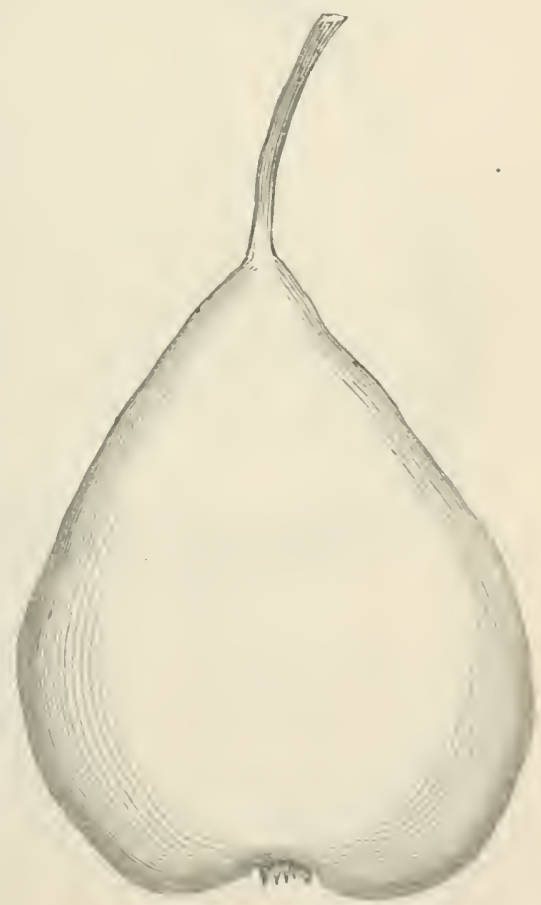


Cикиен.

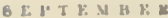

Ii: $: 93$

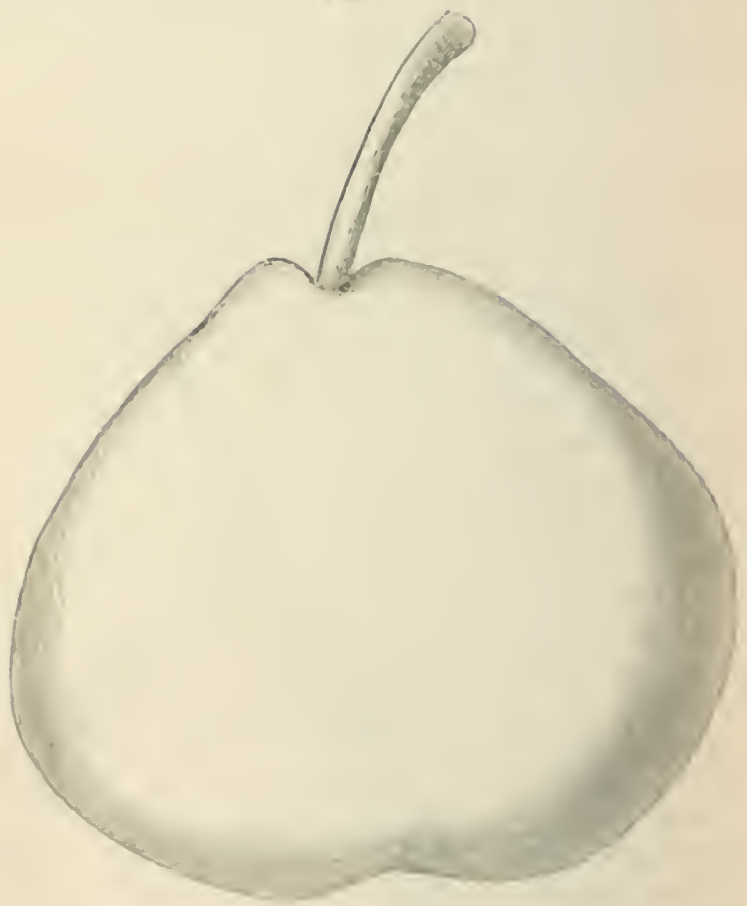

The orgenal tree sill stands in New lochelle. Westelester Unuuly. A. Y. and is traerd by Mr. Brakuass to the Huguenot sentlers. It is remarkable, that wherever the Huguemots sentled, the l'tar atonumb, an 1 hative varicties of grent execllence are emunou. Around New Rorlulle also originated tho l'arsonace. Hac Iluntumglon, and otheres of less note.

The Church Peur is urresular nngular: oblate turbuate; stem, 
long, stout; shin, Jelıow when ripe; flesh, very buttery, melting and juicy; with perfumed rich flavor when in perfeetion. 't, has been elained as the l'latt, which it much resembles, but the identity has not yet been established.

Tree vigorous, liealthy, a great bearer.

\section{Dearbora 's Shemling}

A U G C \& T.

A very nice, juicy little Pear, grown in: more than forty years around Boston, where it originated.

Trec, a most prolific bearer particularly repugnant to the Quinee.

Fruit, when perfeet, very juicy; alinost incling, and of a refreshing, sprightly flavor, but it. is quite often insipid and flavorless, and always so small as to be unfit for market enltivation. Skin very smooth and elear, slightly dotted; ripening with a uniform light yellowish glow. Sliapenearlyround, stem long. Ripens in middle Angust, but is not in eatiug condition quite as Fig. 91.

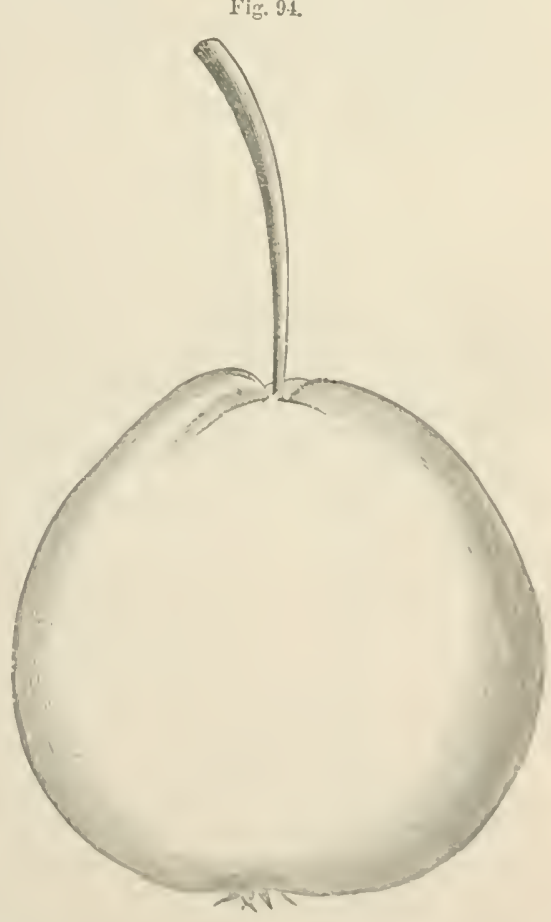
soon as the libodgood. 
BF:crRÉ brow:

\begin{tabular}{|c|c|c|}
\hline 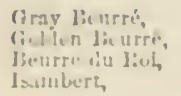 & 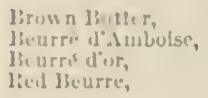 & $\begin{array}{l}\text { Beurrer Honge, } \\
\text { lienrre lheree, } \\
\text { li. de'Trevetri-u, } \\
\text { Leurro Luter. }\end{array}$ \\
\hline
\end{tabular}

Isutubers

lied licurre,

G IPTEM I I T.

These are but few of the synonyms of this once popular l'ear. When in perfection it lalies the first rank for melting, buttery texture; abundance of juice and delicious sub-acid flavor, but it is the very chameleon of Pears, and is so uncertain lhat but few can reasonably hope to crer bring it to its highest cxeellenee.

Fruil, rather large, oblong obovate, stem and flesh mecting without shoulder or basin; skin, a little rough and rusty; and color "such as the gods pleaso." Unfit for general cultivation.

\section{Dertces d' Marunapont, of Bruguem. \\ NOVEMBEE A X D DEOEN BER.}

The Tree is described by Braksass as fecble and mhealthy in Belgium; but growing inuch better in this country, whero it is still $\mathrm{not}$ very vigorous. Shoots long and upright.

Fruit recularly pyramidal, tending to turbinate. sometimes angular; stem short, thick; slin rather rongh; yellowish green when ripe. Flesh buttery, melting, very juicy, sweet and highly perfumed.

\section{BะTRLÉ HARTY.}

Beurre Sterkman.

BEFTENDEI A N D OOTOBER.

Frnit large, obovate pyriform, nne-sided like the Beurré d'Anjou, light reddssh green, with brownish spots : stem stoutish, of mednu lengih, inclined, set in a moderate eavity with a high shoulder on tho laruer sude ; calyx much spread; basin broad and slanllow; buttery, melting with great quantity of rich, sparkling, vinous, perfumed iuice. The tree grows vigoronsly on both pear and quince. 
Dix.

OOTOBER TO DECEM BER,

Fig. 95.

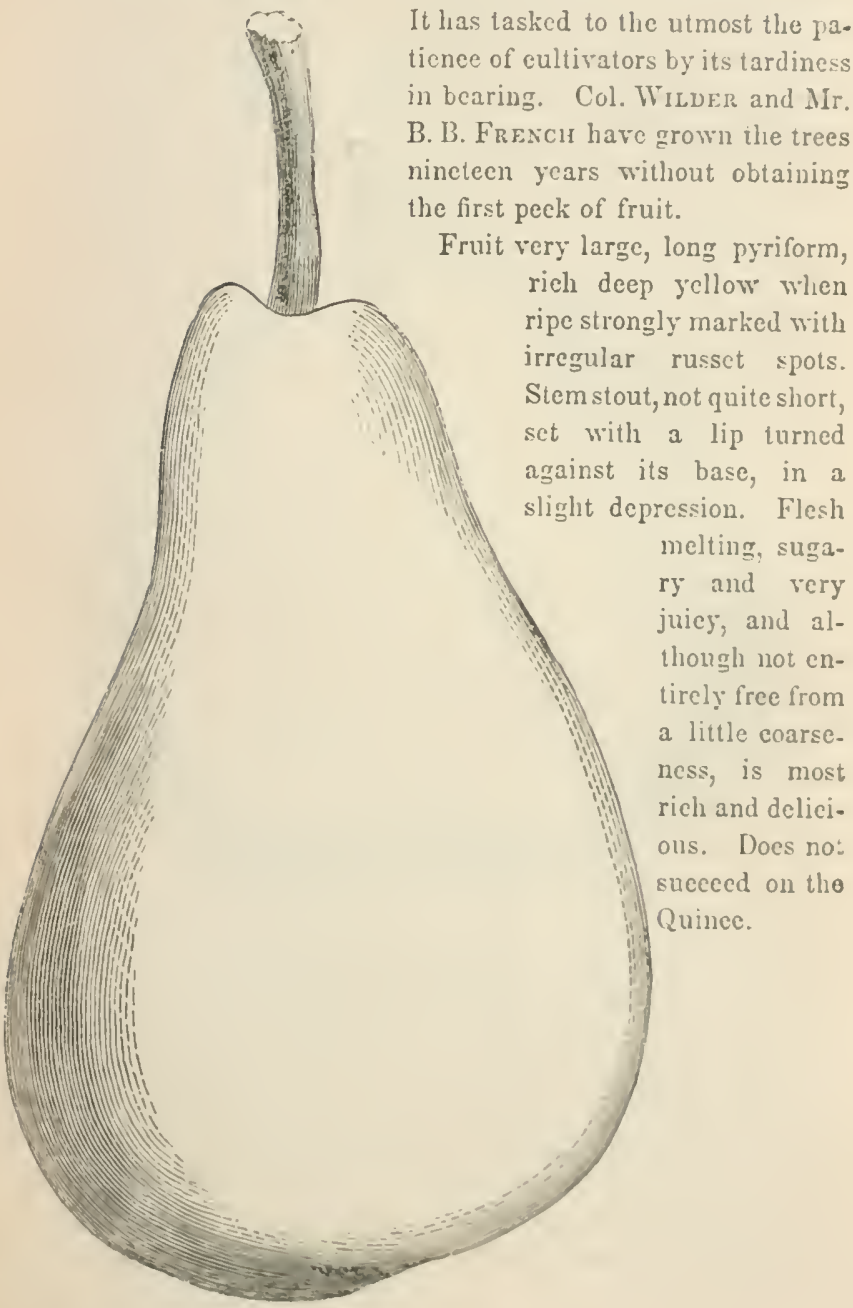

The Dix is a native of Boston. It has tasked to the utmost the pa. icnee of cultivators by its tardiness bearing. Col. WILDER and Mir. trees without obtaining rich deep yellow when ripe strongly marked with Sicmstout, not quiteshort, Stem stout, not quite short, set with a lip turned ry and very juicy; and although not entirely free from a little coarse. ness, is most - 


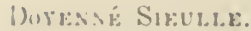

Siculle, I beurresieulhe, I Eergamotte Sieula

Fig. 26.

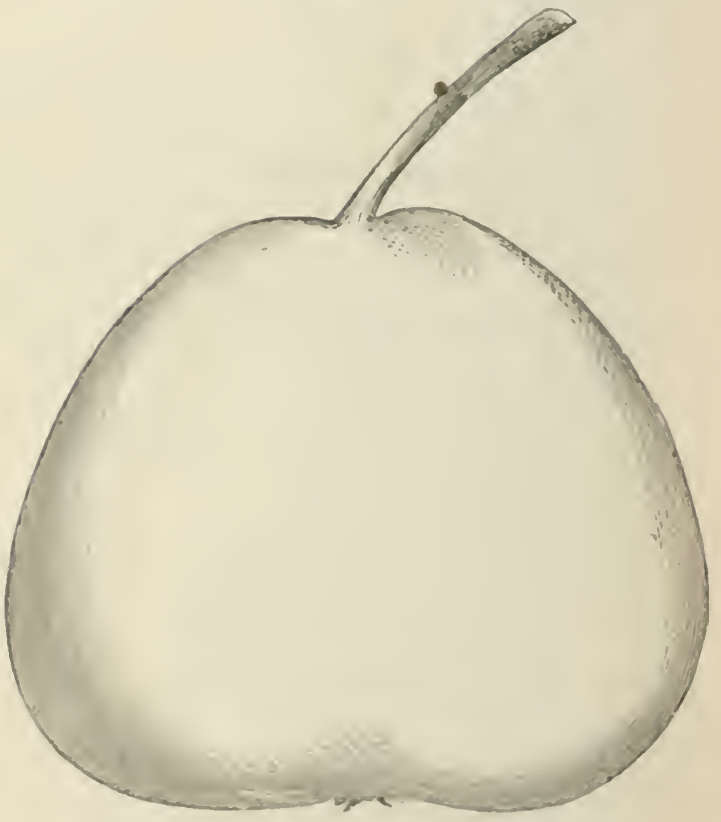

This is a most excellent fruit, rather large, very juicy and but. tery, somewhat coarse-grained, about half melting. Shape peenliar roundish obovate, and rather angular. Skin, bright, dark green, changing to a greenish yellow, much dotted with green spots.

The hardiness and vigor of the tree and remarkable floductiveness entitle it to high estimation as a murket pear, althongh the fruit is hardly high-colored eunugh for the whimsieal taste of a capricinus public.

Its growth inlieates fituess for the Quince. Season, Oetober and Novenber. 


\section{DoYexté D'Alexcos.}

Dorenué Gris d'Tirer Nonreau, Doyenne Gris d'Iliver d'Alençon,
St. Mirbacl d'Iliver,

New Gray Winter Vergalica.

DECE II E R TO A B I IL.

Fig. 97.

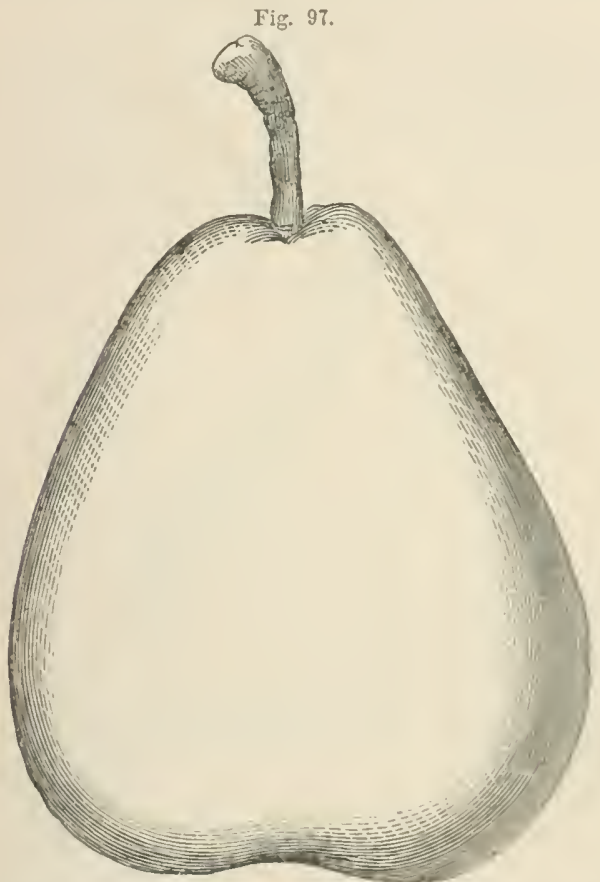

Although not yet sufficiently tested, this pear has reeeived the highest praisc, wherever well cultivated. I have proved specimens from several localities, and all were excellent. The tree is vigorous, of handsome shape, easily trained to a pyramid, docs exceedingly well, and is best on the Quinee. Fruit, oborate, obtuse pyriform, with rough, thiek, astringent skin of russet green, with coarse russet spots. Flesh, rather coarse-grained, ret melting juicy, and almost buttery, with a sprightly vinous and rich flavor.

With proper treatment it keeps till $A$ pril, which makes it valu. able for a market Pear. If kept warm it ripens in December. 


\section{Freneric of Wirtembers.}

I.ol do WIItemberg. $\quad$ King of WrItemberk. venuleu drite.

6 I TEN $\mathrm{ELE}$.

Fig. 93.

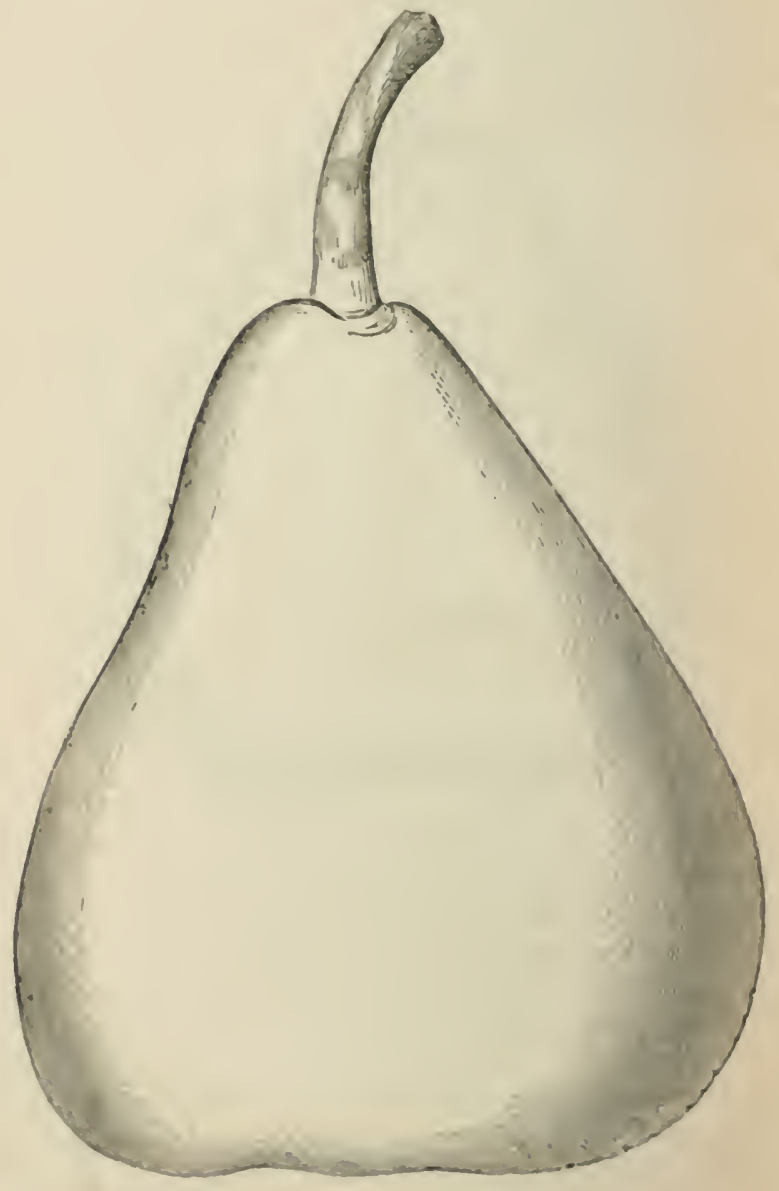


I cannot bring myself to slight this gorgeous fruit, or rate it as low as some ponologists. It is cerlainly the most beautitui object that lias been colored by the peneil of nature. It hangs upon the tree like a drop of gold and erimson, its tints deepening day after day. The flesh is white, melting, and delicious; and when in perfection, sweet and buttery-leaving little to be desired by the taste of the eater. Its growth is singular; the leading shont is tall, stout, stocky, with few or no radial branches. Does not easily talse the pyramidal form.

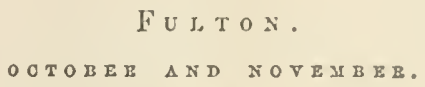

Fig. 99.

The Fulton is a beautiful Bergamot-shaped Pear, of a dark, russet brown; - rich, sprightly flavor, often; and although not juicy, is not by any means dry.

The tree is said to be hardy, but a poor grower. It has adinirers who elaim for it the best qualities: but in my experience it is too small for a markict Pear.

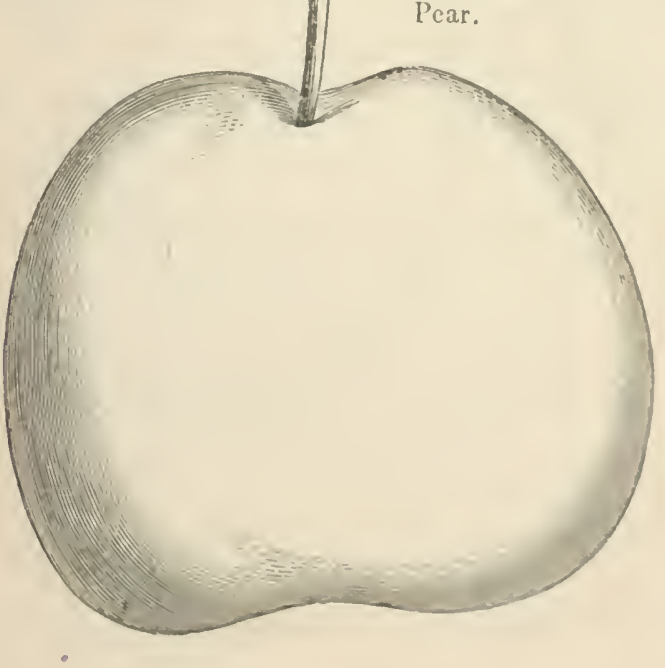


Goldex liniturí: of Butbon SETTEM BE R.

One of the most elear. golden-skinned, and beautiful of iruits. It is usually capped with a ricl russet around the stem, which is quite long and slender, set in a very slight basin. It is quite small, and not unfrequently much resembles the DearBorx's Secdlung. It is often far from buttery, occasionally a littlo acid. with an abundance of sprightly juice. When perfeet, it is buttery, melting, of a rich, jleasant sub-acid flavor.

Good on l'car or Quinec.

Fig. 100.

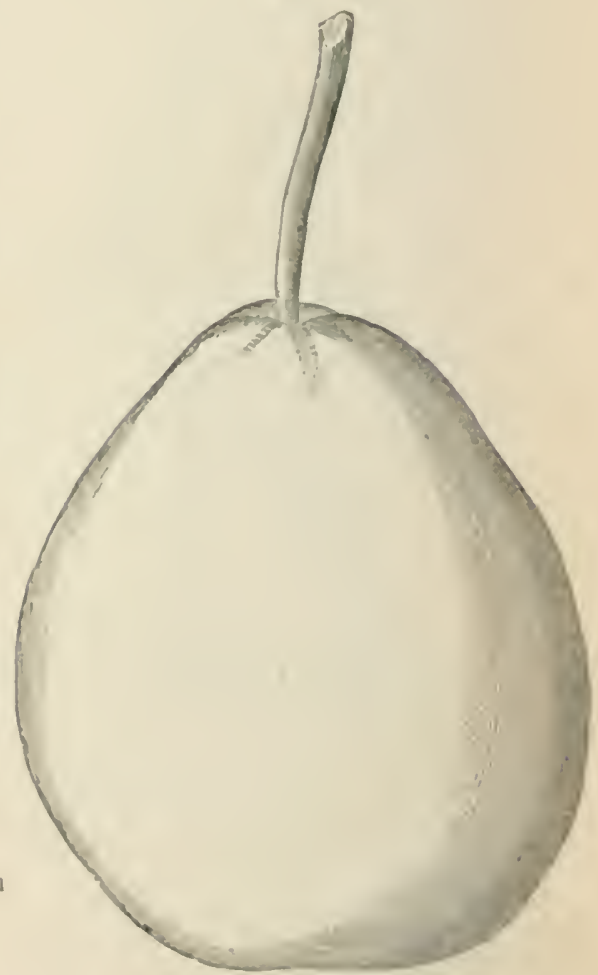


Gray Doyexwe.

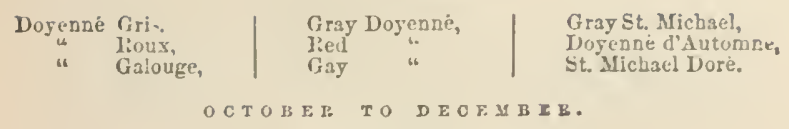

Fig. 101.

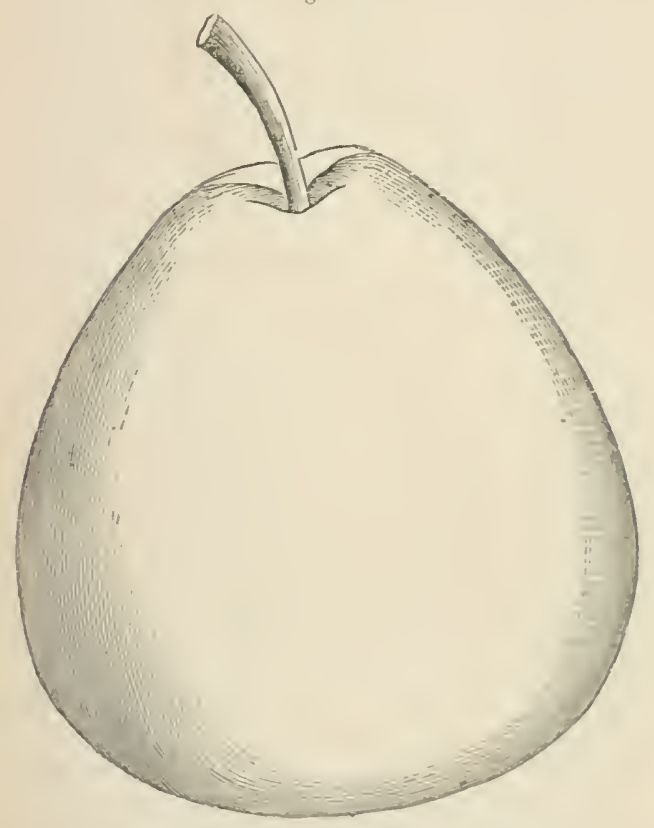

When in perfection, this fruit eannot be too highly praised, bur unfortunately, like the White Doyeuné, \& subject to cracking and spotting, until it loses the very semblance of a l'car. It much re. sembles the White Doyenné. It is a little rounder than the Vergalicu, with flesh of the same delicious, melting, buttery, fine-grained texture, and like tho latter, is in every respect the very type of excellenee.

It will not come to perfection on the Atlantic Coast. 
HOWEL.

O O T O B I B.

Fig. 102.

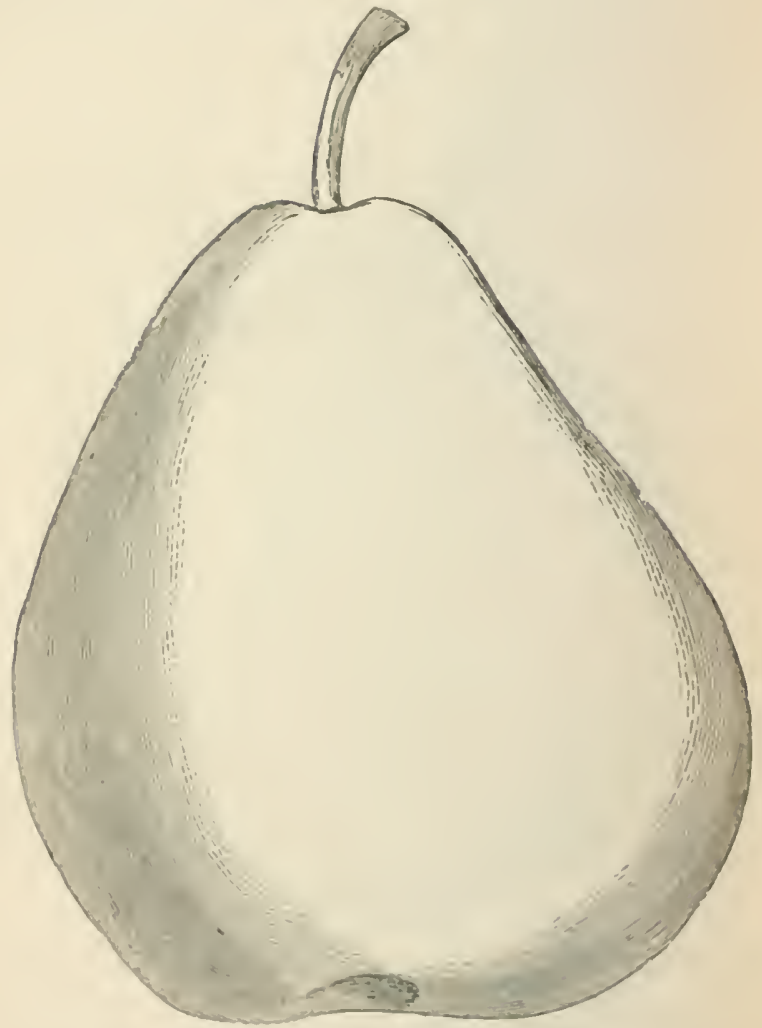

I know of no reason why this should not bo ranked first-rate, except that it has not been extensirely proved. It was raised from the seed by an gentleman in New Intven, whose nano it bears. It is classed by the Anerican Pomological Society for general enltivation. 
The fruit is large, obtuse pyriform, obovate; stem rather more than an inch long: curved, and set within a eavity: skin a clear, rather pale yellow when ripe, with small russet dots, and vecasionally a faint blush. Flesh very melting, with a rich, sparkling; slightly acid juice, faintly perfumed. The tree is vigorous, but not very produetive when young, has not been much proved on the Quince.

\section{Madeleine.}

Citron des Carmes, 1 Magdalen.

J U L Y .

A favorite from its early ripening. It is very delicious when in perfection, melting and juiey, of small size, somewhat obovate, tending to pyriform; stem long and eurved, skin smooth, light, yellow green.

The fruit is very often far from first-rate; the tree is very liable to blight.

It is surprisingly vigorous in its growtl, in favorable locations, and is so regular in the formation of its branehes as to readily form a handsome pyramid.

We shall look in vain, however, for high flavor, or great exeellenee, in pears ripening so early, but as the taste las not become eritical by comparison with antumn pears, wo are mors easily satisfied.

Fig. 103.

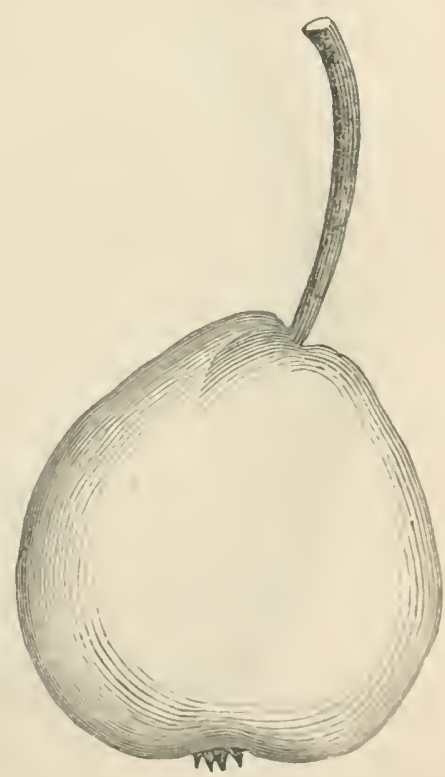


Marie Lolisk.

Fartun Maria Luuise, I Mario Chretiona.

Fig. 101.

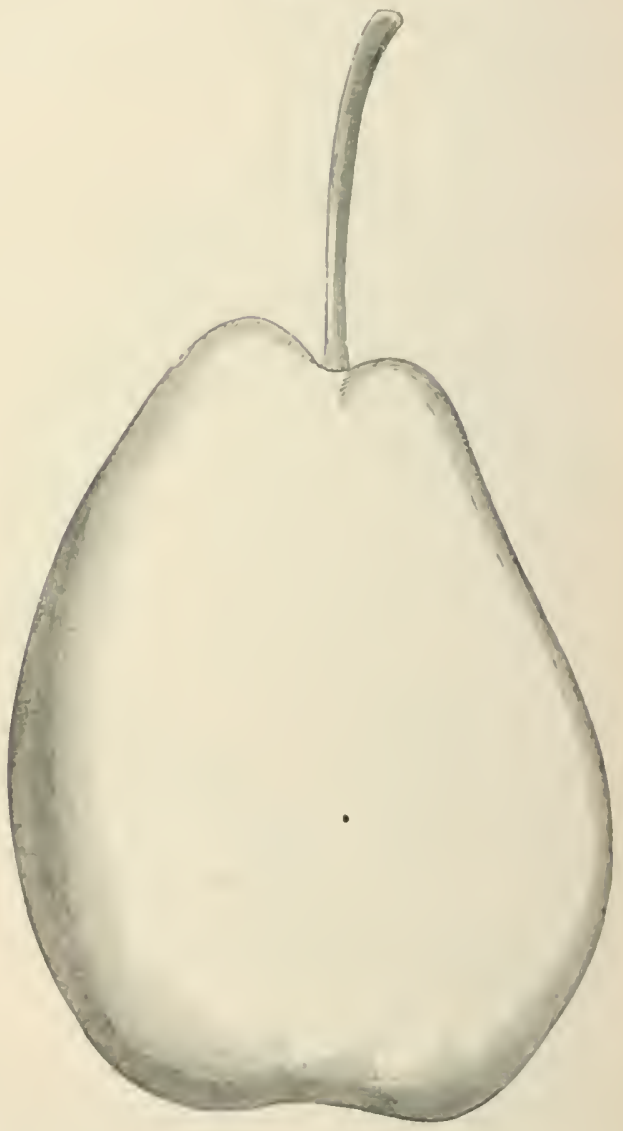

'I'his is a most execllent and beautuful pear, but the tree is a fechle strategling grower, formung uuncrous shoots; casily shaped 
to a pyramıd, but continually escaping from it with its swecping, curling growth. Fruit large and beautiful, oblong. curred pyriform; stem long, curving to the smaller side, set in a slight depression with a shoulder on the larger side; a rich, elear yellow when ripe; cheek marked witl russet spots; flesh a little irregular in quality, but usually buttery; melting to a remarkable degree with a delicious sugary, sparkling flavor. Does not succed on Quince. Season, first to middle of October.

NAPOLEON.

Medaille,

Sucré Douce,
Roi de Tome, Poire Liard.

BEPTEMBEP A X O OTOBER.

This beautiful and delicious pear has only in few instances sustained its European reputation in this country. It has not generally sueceeeded on the Quinec; on the Pear it is a beautiful and vigorous growcr. From observation, I conelude that strong, rich clay soils are best suited to it, and that it does only moderately well on light or porous oncs. Its foliage is peculiarly beautiful, having large glossy lcaves like the lemon tree.

Fruit, medium to large size, with very smooth, clear, green skin, ripening to a pale clouded yellow. Stem, stoutish and rather short, set in a slight depression; calyx in a broad shallow basin. Flesh white, melting, being but little more than so much sprightly vinous juice when perfect. Many cultivators are confident that the older trees will quite uniformly bring the fruit to perfection, with proper care in ripening.

It is certainly, when in perfection, one of the lighest flarored pears, containing, as has been said, so great an abundanec of de. licious juice. Its most serious defects are, the small size it attains in unfavorable soils, and the oecasional spotting and cankering claraeteristic of the White Doycmé.

It has the same thin smooth skin, as the latter pear-a peculiarity of those pears which eanker. 
Nouveau Polteav.

NOYEMBZI.

Fig. 105

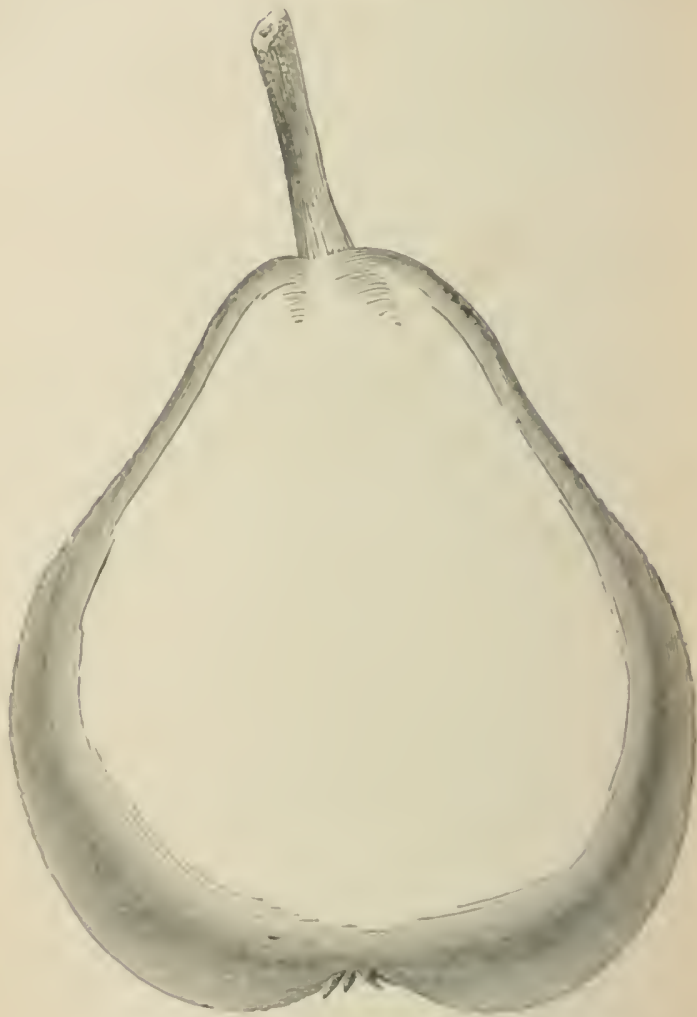

A vigorous, handsome tree, the fruit of which, Colonel WILDER's description, in 1850 , has not too highly colored. In size, the fruit often nearly equals the Bartlett: obtuse jyriform, somewhat sunken near the neck: stem short, stoutish, set without any depression; calyx very open, with the parts turned back. Tho 
fruit is nol attractive, being of an opaque green, with an occasional blush on the cheek; but its melting, juicy clsaracter, and rich, sugary flavor, delights every paiate. To insure perfection, it should be grown on the Quinee.

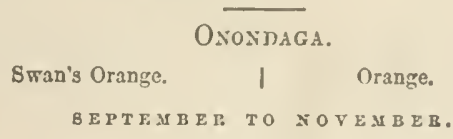

Fig. 106.

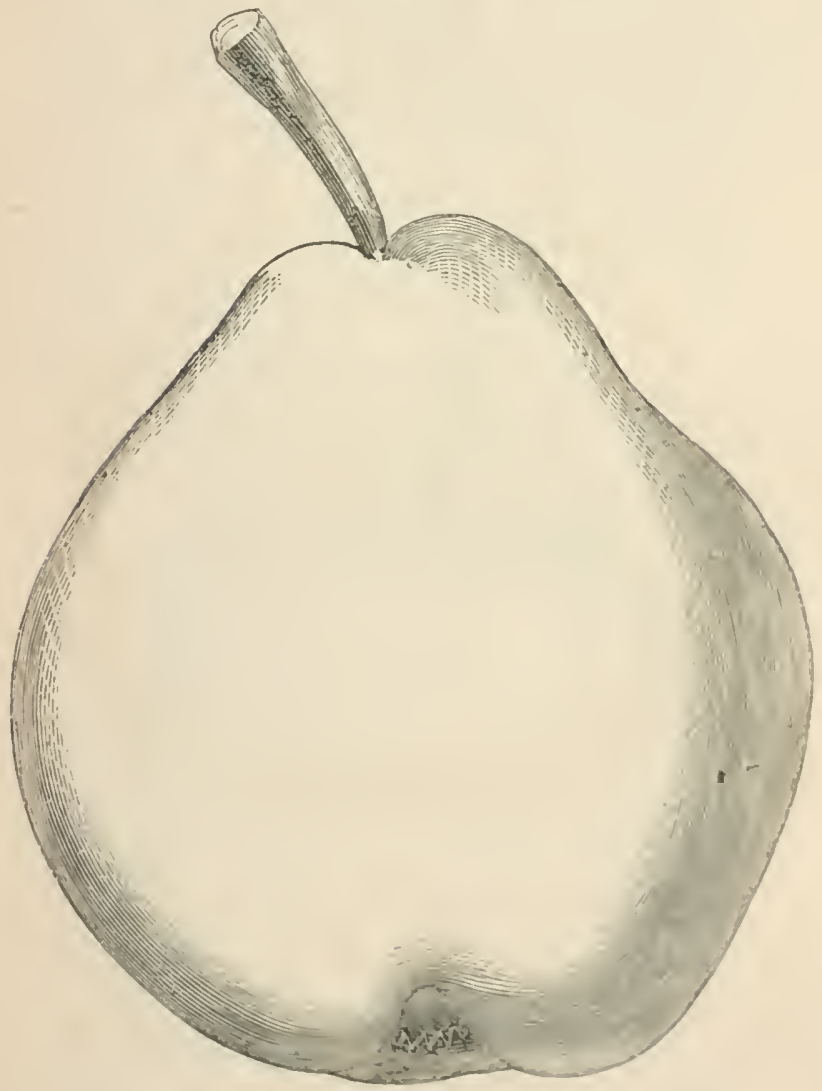


In a rich, strong, elay soil, this is a noble, beautiful, and deli. cious fruit, but it is liable to great variation. The tree is quile distinguishablo by its $\mathrm{s}$ gorous and naturally pyramidal form of light grayish slooots. It is very productive, and grows equally well on lear or Quince. The fruit, when perfect, is melting, but. tery; and juicy, but always a little granular, and sometimes acid. It is of a rich, deep yellow; relieved by russet dots; and from its color and obovato shape, was named Orauge. It is more often an obtuso pyriform, thickest in the ecntre, divided into five lobes, between the centre and ealyx. It is a splendid market fruit, not always first-rate, and only adapted to certain localitics. Its average is equal to that of tho Duchesse; but the largest never equals in size the best specimens of the Duchessc.

Oswrgo Bretrí.

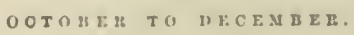

Fig. 10 .

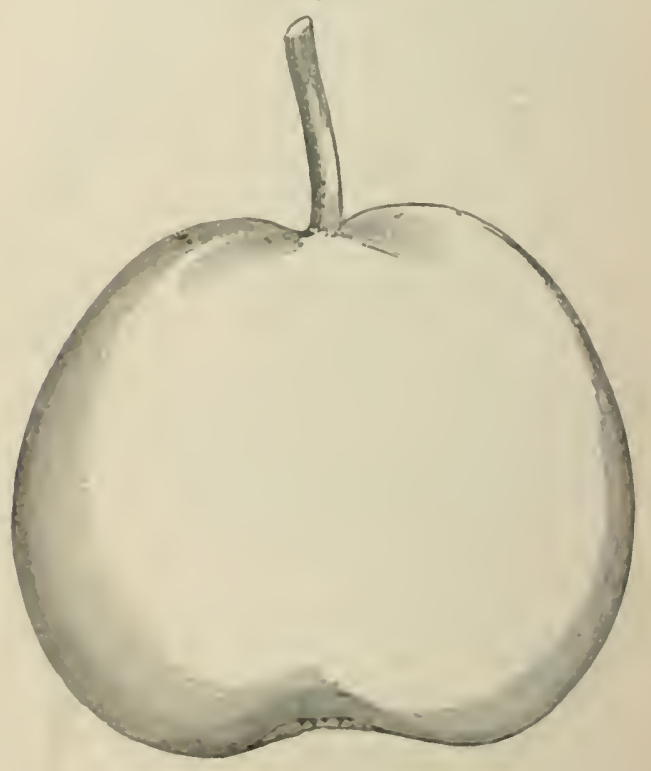


Originated in Oswego, New York; by Mr. W. REaD. Its great hardiness, long-keeping, and exeellence, inate it worthy of general eultivation. It is vigorous and productive. Fruit medium size, oblate roundish, a beautiful einnamon russet, becoming jellowish when ripe. Stem short, set deep in a very regularly rounded basin. Flesh buttery, melting, juicy, high-flavored, and aromatic.

Parsonage.

8 E TEM B E B.

Fig. 108.

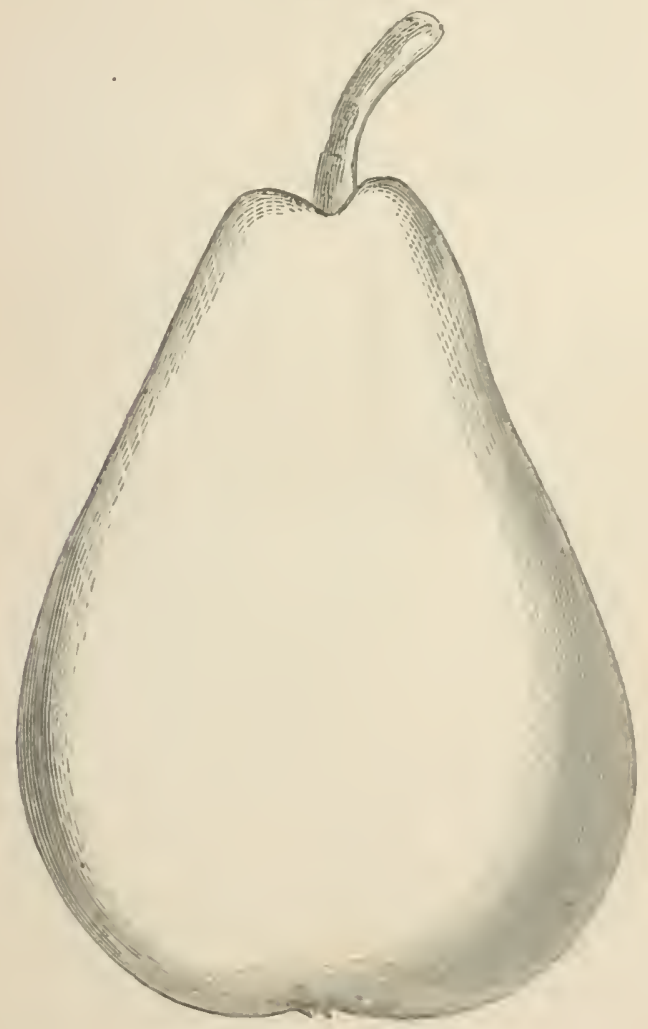


Ot the sane origm as the Church, and nearly equal excellenee. Fruit trom the nednum size to large, obtuse pyriform, and obovate; stin nearly orange yeliow, with a dull red blush, and somewhat russety; stem short, thick, Aeshy at its insertion; flesh melting, sugary, with rich sparkling juice; high flavored, but a little coarse and granular.

\section{PARADISE D'AUTOMNE.}

\section{Calebasse Bosc. I Princesse Marianne. Marla Nourelle.}

Generally mistaken at first sighth, for the Beurré Bose, which it closely resembles. But the tree of the Bose is eomparatively feeble, while that of the l'aradise is strong and vigorous. Fruit large, pyriform, tapering up upon the stem, which is often nearly two inclies long and curved; skin, a rich, yellowish brown russet. Flesh white, buttery, of very rich delicious flavor.

\section{Passe Colmar.}

Colmar Gris.

l'sse Colmar Epinceaux. Colmar souveraine. Colmar I'reule.

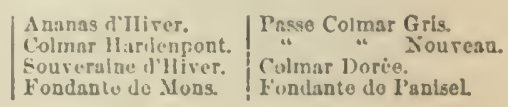

NOVEXBI. TO JANEA R X.

There are mauy other besides theso more common synonyms. It is such an abundant bearer, that the fruit, especially on young trecs, must be thinued to one-third or one-hate, to come to perfection. The growth is often so luxuriant as to absorb too much tho energies of the tree in one direction, unless pinched back.

This varicty affords a fine comparison with the Duclesse, showing the cause of more or less abundant fruiting after abundant blossoming. In the Passo Colmar the pistils and stamens of every flower are strongly and perfectly developed. While in the Duchesse many are imperfect, and but a comparatively small number of pears are jroduced.

The frut unrows in clusters, fair size, and first-rate quality when thinned: flesh yellowish whutc, buttery, melting, juicy: rich aromatic 1layor. It needs eare and shelter in ripening. It is obtuse uyriform; sides suddenly depressed above the centre, giving tho 
appearance of a lorg pyriform whose base liad been pressed up and swollen at the ecutre. Skin becomes whitish-yellow long before maturity, ripening to a bright yellow; with russet brown spots. Stem long, inserted without depression; calyx open; basin shallow

\section{ROSTIEZER.}

AUGUST.

A fine little summer pear, from Germany; and though not long in this comntry, has gained hosts of friends. And alFig. 109. though we must not expect large size and high flavor in summer pears, this variety usually approaches nearest to the fine rich flavor of our best autumn pears. It is very juicy and sweet, with a pleasant aromatic taste. Pyriform, with a long slender, eurved stem. Skin a yellowisli-green, often with a sumny-brown clicek. Tree vigorous, growing well on the Quince.

It is like all the summer pears, very greatly improved by gathering before becoming quite ripe: and the terms of quality bestowed upon them will never be found appropriato or truthful, execpt under this condition.

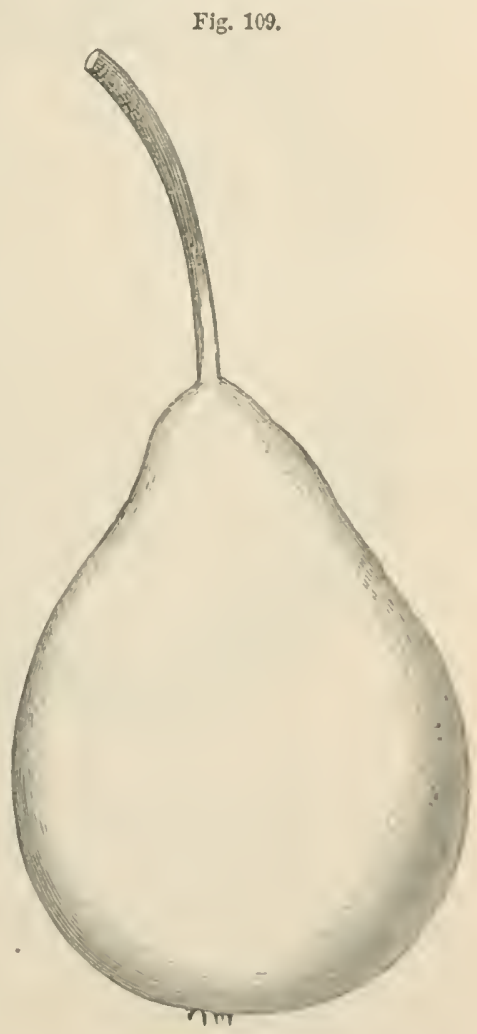




\section{SIIETDOS}

Fig. 110.

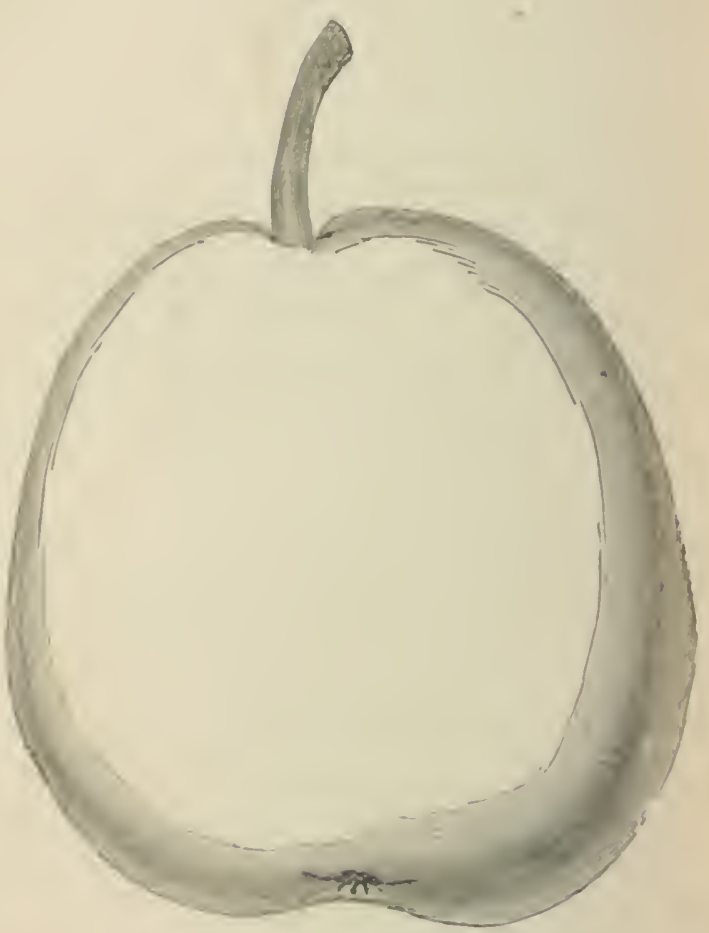

Native. Fruit, medium to large size; beatiful yellowssf brown; the cheek a rich, deen, reddish brown; remarkably sunooth skin; almost bergamot-slıaped, remarkably regular; stem inserted without depression; rich. juicy, inclting, high-flavored, when firstrate; quite often insipid, tending to ancaliness and rot at the eore, when over-ripe. Tree handsone, vigorous, produetive, not suff. eicntly proved on the Quinec. During October. 
Soldat Laboureur.

OOTOBER AND NOVEMBE.

rig. 111.

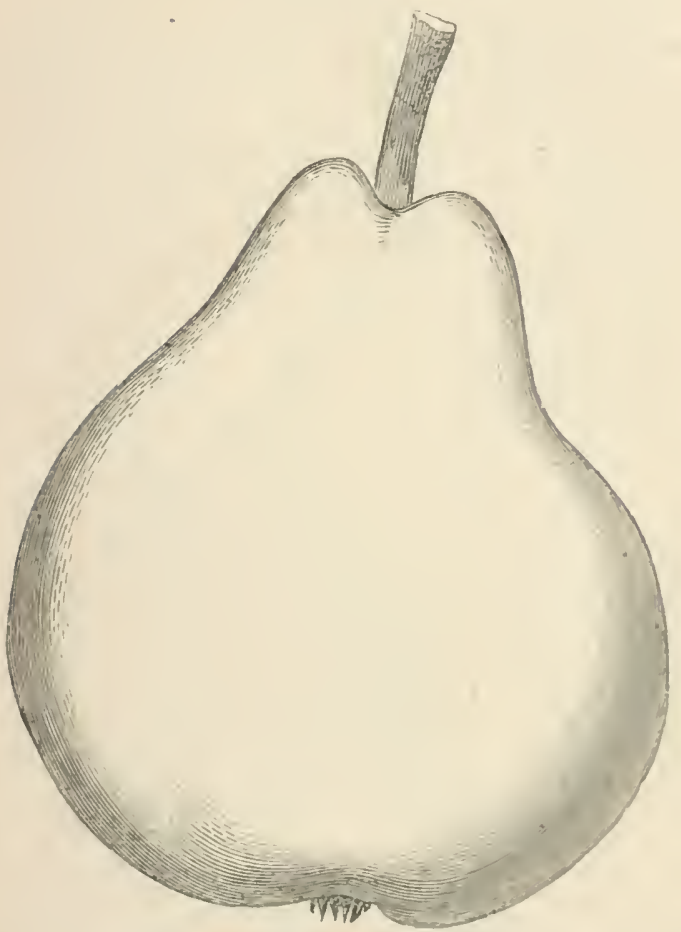

It is quite surprising that this pear has not made more progress in public esteem. Tree remarkably vigorous, rampant grower, difficult to restrain, but, with eare, forming good pyramids. The fruit I consider of the nighest execllence. It is medium to large size, nearly obtuse pyriform, with quite sumken sides, which recedo suddenly near the eentre, giving the lower half a swollen appearanee. Skin quite yellow while lard and unripe, rinening to a very bright yellow with small russet dots. Stem long. quite thick, 
curved, basin small and shallow. It has often, even when quito melting, roarse particles in the llesh: but it is so rich, juey, and swect, high-fluvored, or oceasionally lerfumed, that it must rauk best. The Ravor is best on the Quinec.

St. Michael Archange.

О С т О В $\mathrm{E}$.

The tree of this varicty is of unsurpassed elegance. Fruit, long pyriform, large, grecuish yellow, dotted with russet. Stem not long, quite fleshy at base, set without eavity. Flesh melting, somewhat granular, full of rich, aromatic juice, and when in perfection, exeelled by few. Execllent on quinee or pear, and very productive.

This pear has had the fortume of inany otlicr fruits, to acquire a reputation for mediocrity, becisuse it was jud ged from fruit taken fro:n young trecs.

Flg. 112.

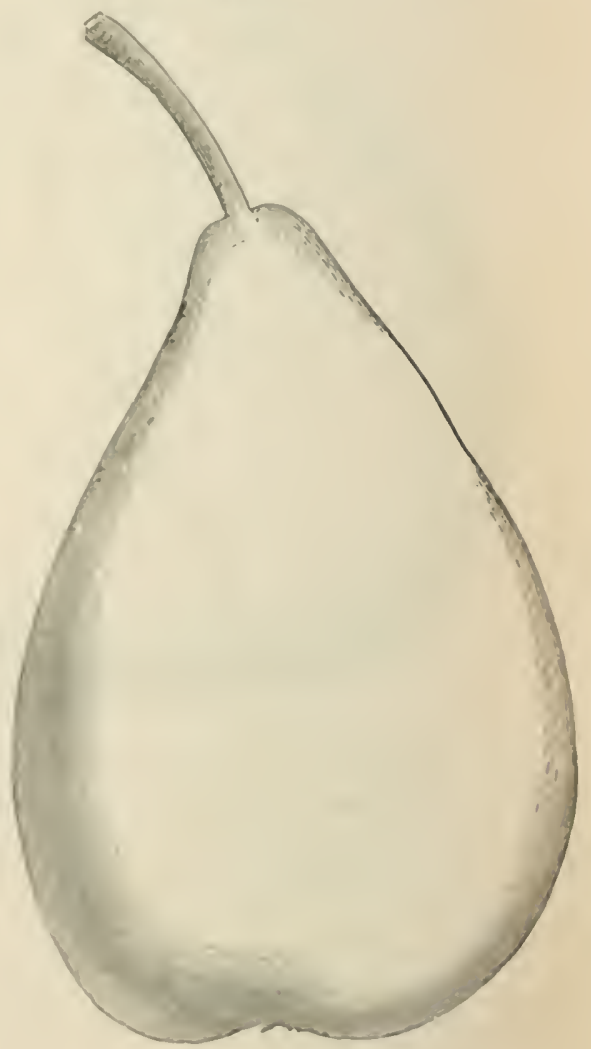


Trsox.

IATE IN $\triangle$ TUUBT.

A native of the vieinity of l'hiladelphia, known before the pre. sent eentury. It has never come into geneFig. 113. al eultivation, though recommended by the Ameriean Pomological Society. A vigor. ous and upright grower, young shoots reddish brown; a very tardy, but abundant bearer. Fruit, small to medium, pyriform, tapering to the stem, which is long, curved, and set with a fleshy junetion, usuallyswollen on one side; dull yellow, with russet red blush on theeheek, often with dark, almost black, spots. Flesh white, melting, and juicy, with rich, sugary, aromatic flavor. For most localities, perhaps, fully equal to the Bloodgood. Should be grown on the Quinee on account of its tardiness

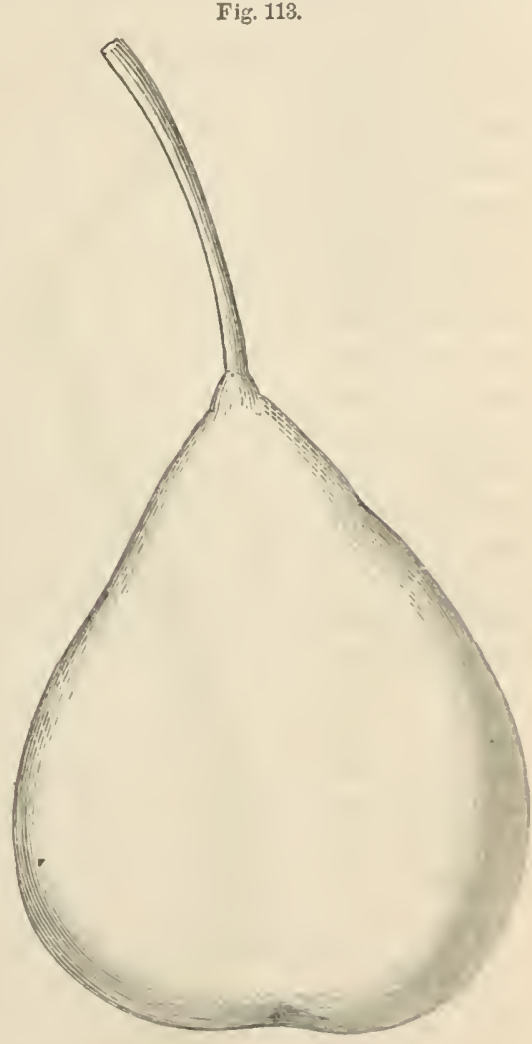


WATERLOO.

Yondante Charmense, Iesiren Van Muns, Jixccllentissimn, beurre ('harmeuse,
Fello Fixcellent,

1)elices des Chartne use

Jeurre do Waterlo,

Vue do lirabant.

A beautiful, excellent Belgian Pear, more commonly known as Fondante Cliar. incuse. It is vigorous and produetive, and promises well for general cultivation. Fruit large, pyriform, witlı uneren sides; calyx large; basin rather deep and irregular; stem long and curved, set in flesh rising to meet it; flesl verybuttery,melting with abundant rich, vinous juice; skin greenish, with deep crimson blush.

Fig. 114.

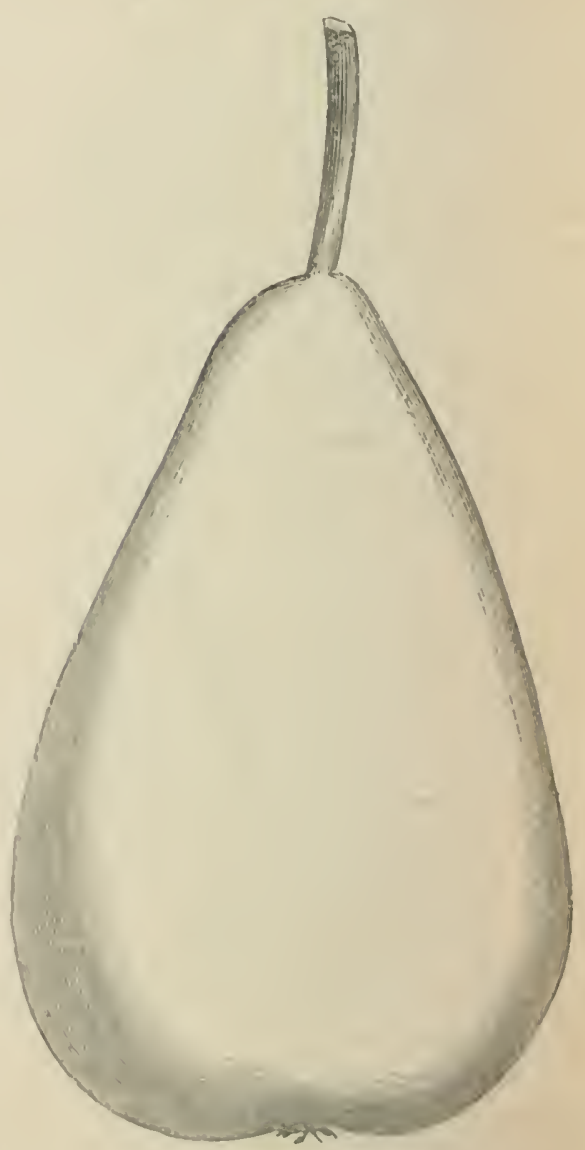




\section{PART IX.-GATHERING, MARKETING, AND FRUIT-ROOMS.}

\section{SOILS AS AFFECTING QUALITY OF PEAIRS.}

THERE is nothing more striking in the cultivation of this fruut than the variation of flaror and texture in the same varietics, on different soils. This causes the vexatious contradictions respecting the value of any and every variety. To one, the Louise Bonne de Jersey seems to deserve all the execration, and to another all the adulation, which words can express.

The color of any variety also varies on different soils, so that the fruit almost defies identification. But this change is as often the result of cultivation. The Louise Bonne de Jersey and the Beurré Diel are particularly noted for their superiority on sandy loams, while the Onondaga and Virgalieu are best on strong clay soils.

The adaptation of soils to different varicties can only be ascer tained by individual experiment.

\section{THINNING FRLIT.}

Good soils, fine cultivation, healthy and rigorous trees. and all the other requisites of pear-growing, will often fail of producing fine fruit, if all that sets is allowed to remain on the tree. The fruit of the Bartlett, Dearborn's Seedling, the Louise Bonne de Jersey, and many other varietics, will set in such quantities, that if thinning is neglected, not one half will reach full size. or acquire their true flayor. Besides, these varieties yield fruit so early, that the trees would be ruined by this precocious fruitfulness. Two years after planting, these varieties will eommenee bearing. and not more than from two to a dozen specimens should he allowed to ripen annually on each tree, until the fith year. The period 
for thimming is, when the pears are from a half to three quarters of an inch in diameter; for, as many fall snon after forming, it is not untrl then the lealthy and perfeet ones ean be distinguished. Not more than one-half of the thinning should be done at onee, and the others may be allowed to remain until we can ascertain the imperfect fruit to be removed.

\section{GATHEIITG.}

There are but few of the finer varieties that are not improved by gathering before they are fully ripe. Not a few have been disearled as unworthy of enltivation, which, by early picking, improve so as to rank anong the first in execllenec. Scveral varietics rot at the eore when left unon the tree till fully ripe, which will keep for weeks when pieked earlier. Among these are, the Flemish Beauty, Beurré Diel, and sometimes the Lonise Bonne de Jersey.

The true test of the proper eondition for gathering is, the cleavma of the stem from the spur, withont breakine, when slightly raised. Some varieties, indeed, should not be left so long even as 1his; the fruit slould not be pieked in a wet and elondy day, or in enrly morning when the dew is upon it, as its flavor is melı affected by the moisture, and its keeping properties much injured. When it is neessary to gather it under sneh eircumstanecs, it. Alould be exposed to the light and air until completely dry. l'ears piekel in the middle of a sumny day are much smperior in flavor, and kerp better: early gathering is only necessary for the summer aud autumn varieties. On the other hand, the late-keeping and winter kinds should be picked as late in the season as the frost will allow. Some of them, such as the Easter Beurré, require a long season to mature.

$\Lambda$ dry and innderately eool apartment should be appropriated to the storage and ripening of summer fruits, and to no other purpose at the same time.

There is mo doubt, that under certain conditions of heat and moisture, absorption as well as eraporation goes on througl the skin of the pear. If vegetables are stored in one part of the room, harnesses and lumber in another, and deenying apples and 
peaches, and perhaps the rubbish and debris of last year's operations remain in a third, feeulent exhalations are absorbed by the skin of the fruit in suffieient quantities to ehange its flavor.

Mr. Wr. ReED, of Elizabeth, whose nursery is almost the perfection of taste and skill, after having expressed strong disapproval of the quality of the Viear, at the meeting of the Pomological Society, writes, with eharacteristie frankness, to the President: "I must withdraw my observations against the Viear, for since our meeting I have ripened mine in a new fruit-room, and found the fruit perfectly melting-more than good-nearly first-rate."

\section{MARKETING PEARS.}

A number of pear cultivators have experienced great disappointment in the marketing of fine fruit, from the indifferent prices offered. This has always been entirely due to improper gathering and ripening. Marketmen will not buy fruit already ripe, to be kept for several day's for sale to the retailers, who, in turn, must keep it as long for salo to the eonsumers; nor will the retailers buy pears entirely green, as few of them are sufficiently acquainted with the varieties, to be eertain how they will ripen up in color and in flavor.

Some of the fruits should ripen in the hands of the large dealers, that they may be exhibited as samples, being put in their hands when green and hard. The great mistake usually made by peargrowers is, to send the fruit to market after ripening, in such a condition that it will not bear transportation, and often lenehes its destination badly jammed, if not a unass of rottenness.

The sceond error is, for the grower to endearor to market his own fruit. Few retailers will, in such cases, offer more than onethird or one-half of the price they expect to pay when their trade demands an immediate supply.

Bruising in the gathering is not unfrequently the eanse of a low price. Bruised fruit will not bring one quarter of the eurrent rate. The rules which should guide a fruit-grower in marketing his fruit are these.

1. Summer and autumn varieties must be pieked, and sent to market when green and hard, must be paeked tight in barrels or 
cases, with coarse inatting around the sides, top, and bottom, so that they eannot slake about.

2. 'They must be directed plainly to some reputable commission salesman, whose entire business is the sale of fruit, giving him instruetions to keep them, until, in his judginent, they would sell to the best advantage. The priee thus obtained will usually far exeed that which the grower could procure for himself.

3. The price of pears is governed by their color and size, as well as by their flavor. The Sechel is the only execption to the rule, that none but ycllow pears will command the highest price.

\section{COI.ORING AND RIPENING OF SEJIMEI AND AUTUAN} Plis ISS.

While many varieties will ripen upon the tree with rieh golden or crimson colors, like the Bartlett and Seckel, all varictics of pears will attain a richer tint as well as higher flavor by a little attention. For the attainment of thic best result, darkness, warmth, and masses of fruit are neeessary. The fruit pieked green should be exposed long enough to become perfectly dry; and is then paeked in cloth-lined barrels and eases. The following, from a report of a Committec of the Massachusetts Horticultural Society, exhibit. the results of attention to minute particulars:

"Mr. Jons (ionvos, of Brighton, Mass, cultivates between thres and four acres, the most part of which is trenehed and under-drained, and almost entirely corered with pear trees, thickly planted, two-thirds of which are on quince stocks. Jfr. G. raises but few varietice, and those such as he finds sell most readily in the anarket, and make the most profitalle return. All his fruit is earefully picked hy liand; and some five or six days before designing it for market, it is earefilly packed away in boxes twenty inches square, and six or eight in depth, with a woollen cloth lining at the bottom, on which is placel nne layer of pears; that is covered with woollen eloth, aud another hyer of prars; when the hox is covered more thickly with woollen cloth, and placed away for what he enlls the sweating process, which gires the fruit a rich coloring, and ripens it for market. Mr. tionos states that cotton does not produce the same ofliet, nor ripen the fruit so fast. And that the result of this eare is best seen in the prices ottained in marketing; for while his Jarliette wre yielding him ten dollars a bushel in Roston, 
other wagons by the side of his contained pears of that vaticty which were sold for only three dollars a bushel, on aceount of their unripened condition.'

\section{RIPENING OF WINTEL IPEARS.}

Much chagrin has been experieneed by those who, for the first time, have attempled to ripen winter pears. Many varietics proclaimed by the books as ripening from December to April, obstinately persist in becoming melting and luscious in November and early December.

The Winter Nelis, the Lawrence, the Beurré d'Hiver, and otlers, attain this delicious maturity in the early part of December, in. stead of kecping sound and hard till February. But the inost disheartening and vexations phase of the matter is, the withering, shrivelling, and premature rotting of the pears, to which a still later maturity las been attributed. The Faster Beurré, Glout Morecau, Doyemné d'Alençon, lose a great quantity of their juice by craporation, and resemble a potato liept one year, quite as much as a pear.

The Pcar, unlike the Apple, has little or no oleaginous matter deposited upon the skin, to prevent the rapid evaporation of its juice, and preserve it from shrivelling, so that the porous and unprotected skin of the Pear readily allows its juice to eseape. In all efforts to preserve it. therefore, we must keep in view this defect. Some attempts to form an artificial corering by varnishes. Se., have been made, but they liare all been condueted whthont reference to the conditions neeessary for ripening, being only intended for the prescrvation of the fruit.

The law which gorerns these conditions may be stated as follows: $A s$ it is only by contact with the atmesphere that pears can be ripencl, and as that very atmosphere abstracls the vilul furits of the fruit, it becomes a necessity that the pear should not be in coutact with frec or moving atmosphere until the period of ripening has arrived.

The Pear. like the Apple; is eomposed of the proximate elements, starch, sugar, and albumen, with water and inalie acil. The ripen. ing of the fruit is the completion of that chemieal proeess by which starch is changed into sugar, and is always the tirst step towards 
deeny. Fruit has reached the point of highest excellenec when it custains the ereatest cutututy of sugar, and the sugar iu contact with the albumen has not commeneed the putrid or acetous fer mentatren.

By protecting them from free atmosphere in elose eases, and by preservation in a cool apartment, we are euabled to delay the ripening and prevent the withering of pears. There is, lowever. a fixed limut to this preservation. The inherent tendeney to decay, which pervades all orranized matter, prevents us from more than temporarily postponing it. T'he Duehesse d'Angouleme, which may, by skillful management, be kept till Christmas, can by no meaus be preservel as Inn⿳r as the laster Beurré.

After a pear lias become somewhat withered, it ean never rupen fairly, as sufficient water is not present to perfect the change. It will be seen at onec, that all the elaborate instruction for shelvun an apartment, and laboriously placing the fruit in single layers thereon, so as not to touch, are in entire contradiction to the rules above noted. It has confounded many an amateur, to find his plain and unscientifie neiglibor with an alundanec of pears at Clıristmas, while his own had all long before decayed.

A gentleman who had but half a bushel of Glout Morecau Pears, preserved them till late in January, by the following plan: $\Lambda$ barrel was half filled with sound Bald win apples. in November, the prears placed unon them, and the barrel filled with apples, and put away in a dry cellar; when taken out, the pears were tresh and green as when first pieked, needing but an exposure of a week or more in a warm room to becomo golden in color and deliciously melting and juicy.

All our winter pears need a somewhat longer season than wo usually have norll of $\mathrm{New}$ York City. This renders their qualıty a little uncertain ; but somo attention to their growth whll usually obviate lhis mecerteinty. Tho large annomut of acil juice which they coutain must be overenue by the alcoholic or saccharine clange. If the amount of the sugar-producing principlo which the trees derive from the soil, or from the atmosphere, is too small, the ripening will, necessarily; bo imperfect. Tho true remedy for thes would uaturally secm to be, that which practice has proved 
to be correet. The small-sized and badly-shaped fruit must be thinned out carly in the season. The rest should be allowed to remain on the tree as long as safe from freczing; and packed awisy soon after gathering, in cases with limited rentilation. Judmment must be exereised in determining the amount of fruit to remain on a tree. The quantity of winter pears must be less than is allowable in the case of summer or autuinn peal's.

Without question, uinler pears, litic olher fruil, can only rijen perfectly in masses. There is some undiscovered influence in the contact of fruit with fruit, that gives to masses a perfection of flavor mattainable with small quantitics.

\section{FIUUT-IOOMS.}

For effecting these conditions of ripening, expensive structures, fruit-houses, and roons have been ereeted, and it is but just in say, have, in many eases, resulted only in disappointment. When one lias not a good dry cellar, it may become neecssary to provide a fruit-room, and the reason why cellars are not generally suitable for preserving fruit is, that they are usually too damp: they should be of low and eren temperature, and dark. Fruit-rooms should be built with double walls, confining a stratum of air be. tween, which is sometimes more perfectly accomplished by tilling in with dry tan, chareoal dust, and similar substances. There should be but one window, and that fitted with double sashes. Vertilators should be provided, which should be allowed to change the air of the room only sufficiently to prevent its beconing leculent and damp. No deeaying fruit should be permitted to reman in the room, nor any vegetables or substanees having ollor. A gentle. man who had expressed much disappointment with the flaver of several fune varieties of pears, was greatly surprised by lizving the cause of the inferiority of his truit pointel out. He at onee conmenced removing from his fruit room all the materials belenzing to the harness and lumber-room, the decaying matteracenmmlaned in corners and boxes, and funished with thoroughly cleansiug ant whitewashing the walls. 'The pears ripened in the room, there. after, were not only a souree of gratifieation in their fine flavor. but of surprise at the means of their perfection. Other fruils 
may be exposed on sliclves, but fears should be inclosed in boxes with tyht-fittug corers, or af the quantly is large, in wellmade barrels, headed up. A fruit-housc, thus arranged and managcd, would be a protitable adjunct to a fruitery. Hut for most aunateurs, a dark closet in the housc, or a room fitted up in the cellar, or even the cellar iticlf, liept clean and sweet, will suffice. For small quantitios of pears, checse-boxes, witl close covers, lave been found cheap and convenient. These sliould be alway frecd Irom the olor of checse, by cleansing in lot water, with soda or lotash. It has becu recommendal and practiced by many to wrap lears in japer, cottun. and similar substances; but I have found all : uch freparations worse than useless. They not ouly absorb the inolsture of the pears more rapidly than the atmosplice, but they abstract the aromil of the fruit, and leave it comparatively tasteless. These subsiunces beiu earbouaceous, act as absorbents of the peculiar flavor, Jike cliareoal.

Mr. B.ıry informed me, l at alter many years of expericuee, lie had found the mosteffective means of preserving winter pears to be: late gathering; packiner away carefully none but sound fruit, in elose barrels, leaving them in an open sled, only protected firm rain and direct rays of the sun, as long as the temperature is above the freezing-point.

The practical difficulties in the use of fruit-rooms secm to have been overeone by Mr. Scmoocey. The acenmpanying plan of his Preservatory lias appeared in the Country Fonlemu, and Americun Agrimulurist. From the latter, the de.eription of its construction, itul the ratiouale of 11 s cellect is extrateted.

(bur illustralion represents onc-half of a huildius, suplnoed to be divided llameng the midhlle, from the ridge-pole to the groumb, m order to hethes s/ ww the intering arrangements. This strueturo may he a J.urar cur, twenty or thirty feet cach way, or ouly a sunall room of hut a few fert in size.

'The sule-walls, $u^{*}, \tau^{\circ}$, and th" Jower aud upper floors, $f$ aud $u$, are male demble. breme filluel in wh saw-rlust. The upper floor, dovever, cousists of a simgle layer of hoards; mailed upou tho under sude et the jossts, with the saw-du.t piled on loosely, a foot or more in thickness. Alove this, is an open space or garret, under tho 


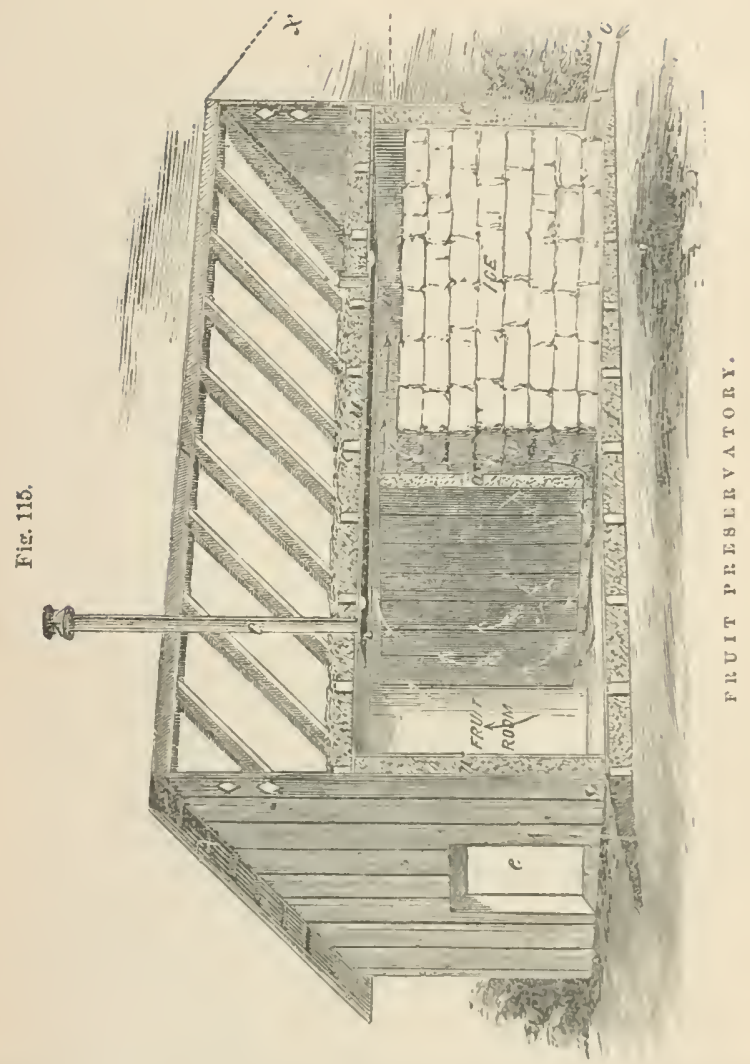

zafters or roof, with holes in each gable-end to admit a free ciren lation of air. The main room is divided into two compartmentsthe fruit-room and iee-room-by the partition $d$. The partition d unites with the walls on both front and rear, but a small opening of a few inclies is left both abore and below it-that is, betwecu the whole length of tho lower and upper edges and the floor anu the ceiling. The ice, as represented, is piled up in a compact mass in the right division, and eoverel in the nsual manier with straw. A small raeant space; $r$; is left between the iee and the division- 
wall, though this is not necessary; unless the cutire body of ice is so compract and finzen togcther as to jrevent the air from circulating throush it The tloor. under the ice, deseends to the right from $f$, so als to earry any waste water out at $o$. There is all ingentus arrangement in the waste-pipe to prevent the aceess of uir or vermin. It will readily be seen, that before the water rists high enongh to overflow the right projection, or gate, the upper or left-hand gate dips down into it, so that the opening is always elosed with water.

The air around and among the ice will always be liept cool. It will, consequently; settle downward, and flow along under tho disision-wall, $d$, and into the lower part of the fruit-room. At the same time, the warmer air will flow into the ice-room through the opening over the division-wall. The arrows show the direetion of the eurrents of air. This motion will always be kept up so long as the air in the fruit-room is in the slightest dewree warmer than that in the icc-room. We sce, then, that by such an arrangement the fruit-room is practieally liept nearly as cool as if actually filled with ice.

There is anolher important end secured by this arrangement; riz., that the air in the fruit-room is kept very dry, or free from moisture. The air always contains more or less of invisible water floating in it. The amount of water in the air depends upon its temperature. The warmer air of the fruit-room takes up moist. ure from the articles there; but when it passes over to the ice, being there cooled, it gives up a portion of this moisture to the iec, flows back below in a drier condition, to take up more moisture as it is warıned again. This cliange goes on unceasingly.

At $e$ is seck the entrance to the store-room, in whieh may be kept all kinds of fool, vegetables, fruit, Se. Should the air nced elnanging at any tims, 10 get rid of odors, it is done thus: Just under the eeiling is seen a flat slicle. Moring this to the left, two holes through it will be brought under the two ventilators, one leading into the open air above, the other into the sarret. When this is done, the fresh air from the garret will settle into the ice. room, whlle the warm air in the fruit-room will aseend throngh the larger ventilator, and pass off. 
CATAIOGUE OF PEARB.

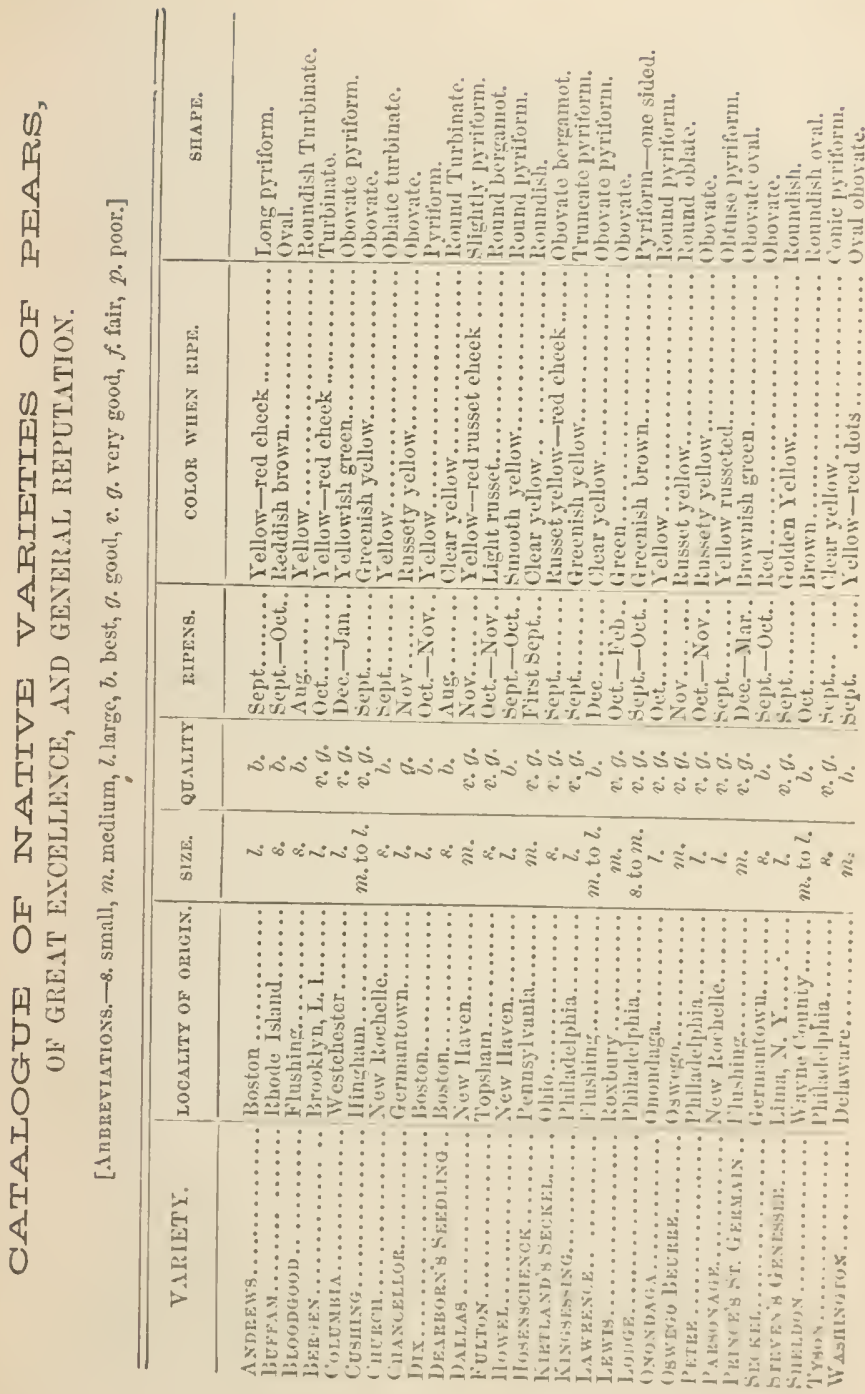




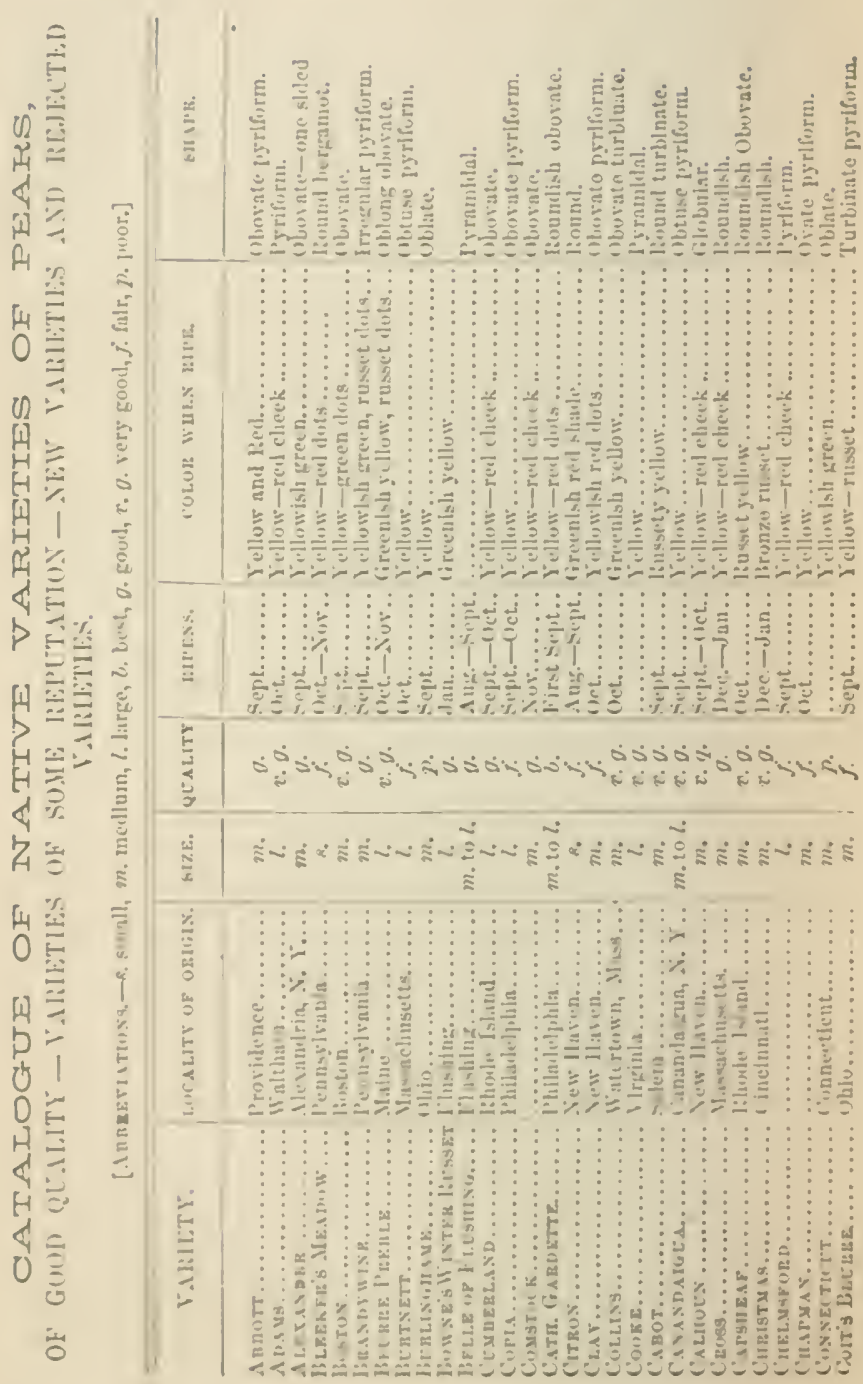




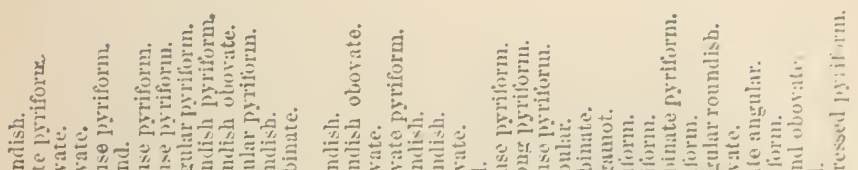

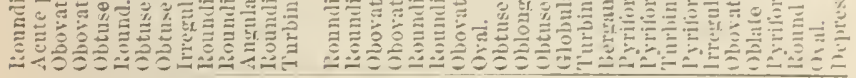

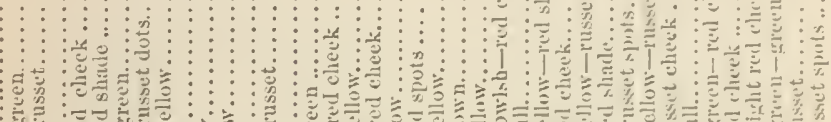
:

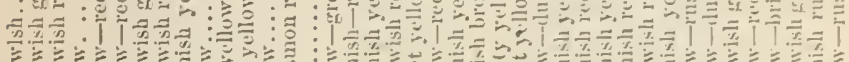

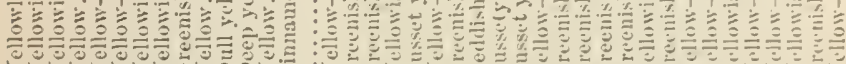

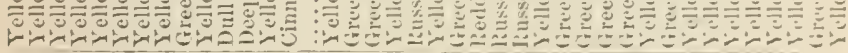

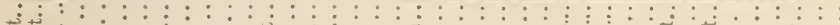



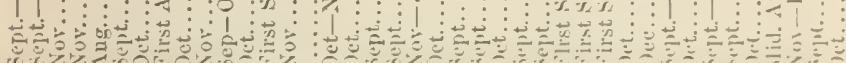

ऊ.

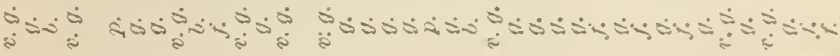

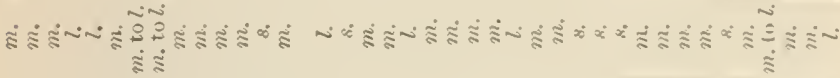

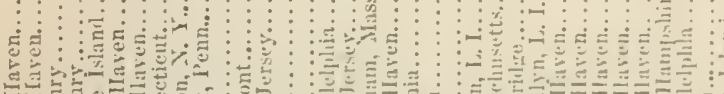

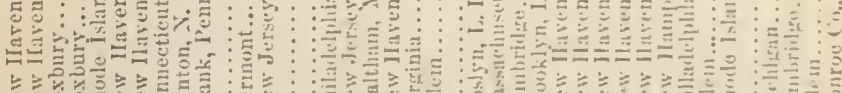

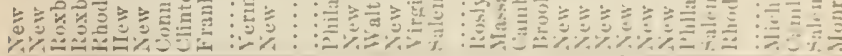

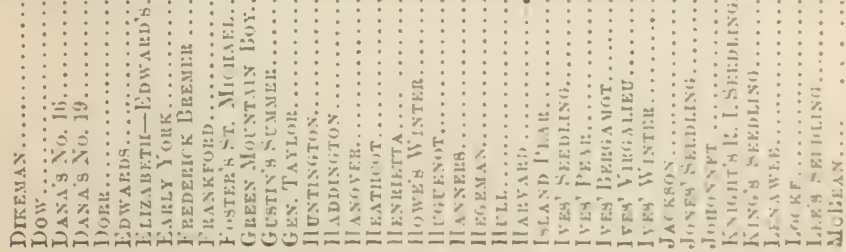




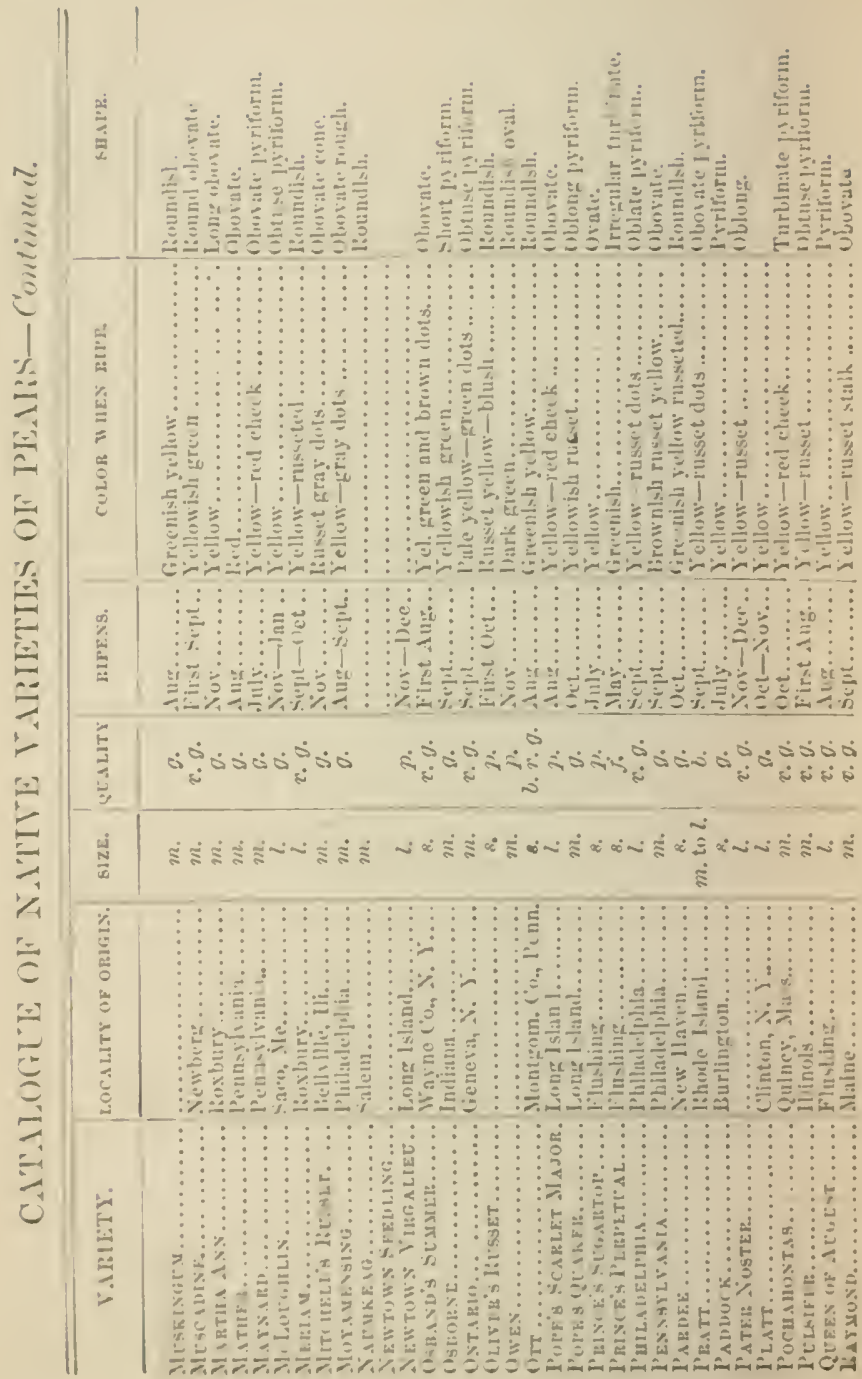




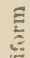

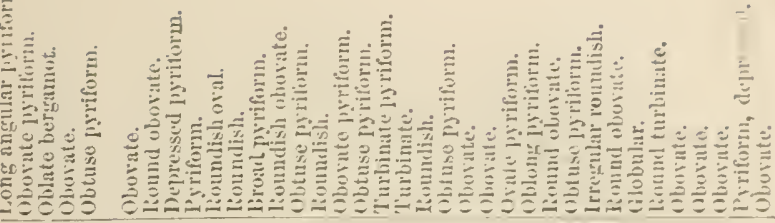

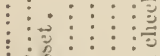

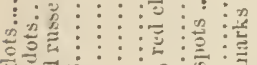

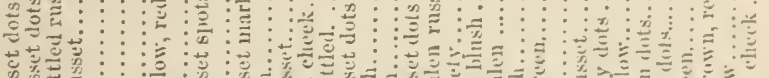

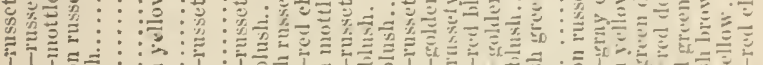

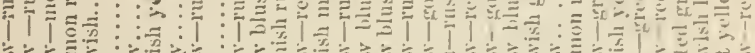

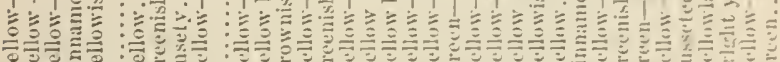

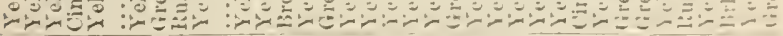

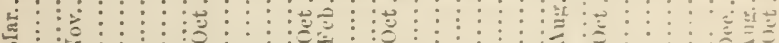

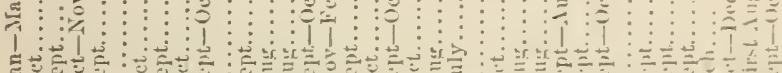

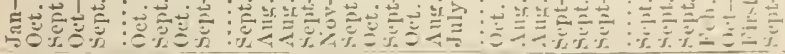

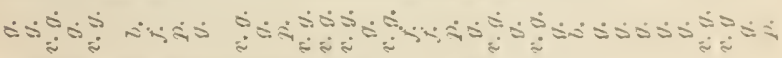

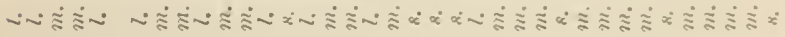

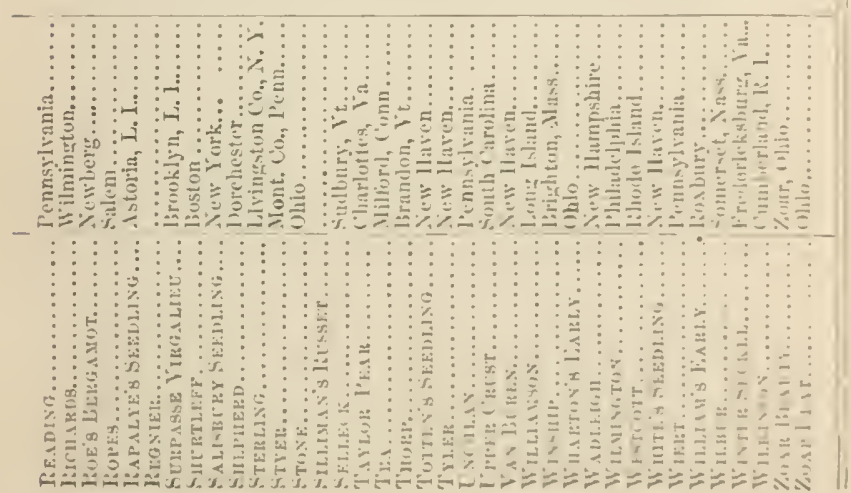




\title{
CATALOGUE
}

or

\section{VMIETLE OF l'EAlis OF FOREIGN ORIGIN,}

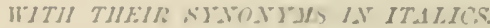

Al. M n $n=$ in.

Aline liI nuar L.

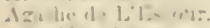

Ah! IIon li 1 .

lidilin mestare.

1. $1 \mathrm{~mm}$ :

Alaerts.

Al subir di rhmane.

Alexist lre Buset?

Al tan lr. l.tul re.

Alexasa lrsu.

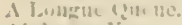

Alpliuine liarr.

Ambrett .

I.pine ure.

Anire de?tann t. sisint-deutr.

\section{Antnax}

Anfelliqu de lior I sas.

In wain le en lin le:

Ansteteredillor.

Ansur.L.

Arl quin mi-jus.

An i tis $n$

$A-r$

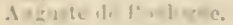

dumblime Jees ter.

Ant be.

Aloal le le lievel.

Alite 1.

Ananian les artrobl.

Amanas al I o

Athore c idik.

Imi, al

$t^{*} \lambda \ln t r i^{\circ} \quad n t y$.

Anglete lins?.

Auturonis, ir.

Amatos

livirin $\operatorname{kn} x$.

$\pi, d, 1$

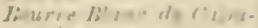
riars

Aml rett.

Amporlde fiphlin ane
In celigre do livile aux.

I th nid Jisurt.

I therpuet ra aros.

Amlirusiz.

Fitrly Beurre.

Anflet rre.

E. livh li nrre.

limbite dillederre.

J.stl, th.

II II,Imis.

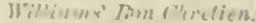

livite litill turte.

II. lat lis alt.

il lunt lheygnue.

lis rlon vitet.

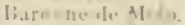
Adele de stivitetereds.

l:. i fres at if intels.

I'ic int en! nle ditgles.

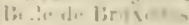

li vired Biarolle.

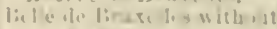
heriul

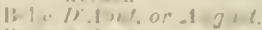

li, afe 1,ri,

lic 18 - Ie tom I.

-1 piter $1, i$.

F isulite ivel.

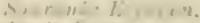

1) 160 1/2 Pi sis.

lin ll dulie.

dlesantre lle te.

be lle Jersw "or I epuia

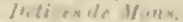

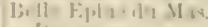

Immin in,

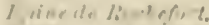

1 a de I I into.

II I, I, A 1 l.

I) rold Jinl, ind.

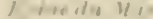

1. nue alu $l i$ is.

t.pule du lorese ir

$$
\text { ( } \because 1 ;)
$$

13e1) Fot inle.

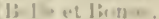
whe unl liver. rimerimase.

Belle l icralie. Bergomothe luriture. dienreluerestit:

liergumede $F$ is rie.

Findinte of - I uturine.

Cironillito:

signeur bing.

billistine dilie.

A de $r$ yents Jarounuello of the French.

Stline dite.

supreme.

lic r:ammet liuffo. 1;iljuturt.

Jinurre Berlus

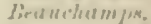

lirrgitmotte cilelell.

I. vi.e de riti,

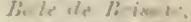

incurreet \& thysa.

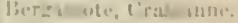

1 asmance.

lieremant, a l'eulio o l'ınanlies

liergumutecra inno d lic

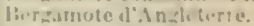

lic rasmote il'A = ion unn.

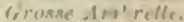

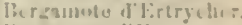

lie resmoted lite.

di wre lat the or wille.

lienrre d Fils.

lis urre lionde.

Milan filan.

Milun do las Fonreiere.

If uille limele.

It ratiluote d'lite l'anachno

It) rasmota J)roumet.

lierg-inutu llusurt. 
Berganucte d. Uniwbourg. Bcurre lerckmans.

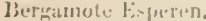

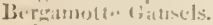
Bivias liesisinet.

Ires' Bergilmot.

siluntern.

boune limerge.

frurles livirie.

Diamurut.

Fermanutte d'Esperin.

Tiercamot te Gamilry.

beramute Leselle.

Bergimutte de Millepieds.

Jercrimette d"IIollawde.

IJullunit Berigunotte.

Benred dlencon.

Bergumotle d'Alencon.

Jitrain de Jongrers.

Liergumothe de Fougere.

dinurelle.

Lord Cheeneys.

sitwer.

Berganict, Easter. Biorculmulle rle l'aques. Jirgumotte dirixer. bergamolte de Bugi. Tivigamolle de Tunlouse liwberts's heejing.

linter Bergrimotle.

ludileingtun.

lun!l Fuirling.

rulint.

\$\%. II"rylain al Iriver.

jolferne d'llie's.

Nivlilit.

Jirumot, lageret.

Leisimot, - ilisas.

sicises belyamol.

Eerriatuot, Antumu. Einslisth bierpumiot. (is)mon [ierratmot.

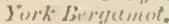
Linglisil ilutumn Burgumul.

IBerganot, Early.

Jerítmot, Sullumer.

Belmituot, Il:tujplun's.

siummer Iberestmest.

birgumat ol lingetarre.

Fingul's.

Berginnolte ale.

Nicetek Bisctarmot.

Ellumideth.

licreramotte do Malitus.

Beriramotte de l'arthenay. l'virealu.

Burimutte, Ruse.

lieurre Antoine.

licurre Antoincltio

Jis urre Anmenicre.

lieurre liskehelio.r.

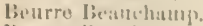

lisurro lienoist. lit neils.

Bearred I agusted licnoit. licurre bicmut.

Jicure blane sle Nantes.

linure de Nintes.

Deurre Suntais.

Liurre Busc.

Busces Thasulierlirne.

Belirre, liater.

Eergilmotie de la rentecule.

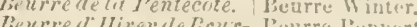
elles.

Doyenne d"llirer.

boyenne du l'rintemps.

lieure lioupe.

1) Pitie.

Burure de I'aques.

J'Hillipe de l'uryes.

Dezi C'tuamonte? tres gros.

Chaumontel tresgros.

cunning.

signene allirer.

Leurre Gris d'Iliver Nouveau.

Bewre Gris d"Iliter.

Ijt ure fris de buron.

Bisurelis infuerieure lienre de fontenay.

Benre d'Anjust.

Ne I"lus yenris.

Vec J'lus Hexris.

Benre l liel.

Diels bullerbirne.

liel.

Inerethe Reryale.

Gios Jurcthec.

rileste.

Jiex tres Tolrs.

Jillon, or diros Dillon.

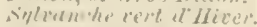

Linrere liougult.

Withille.

Berrere il bilic.

J)e Melun.

Melin de IIUp.s.

I.oijul.

7), $n-(1), n$ n.

Flurimuril.

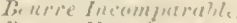

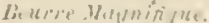

licurre surkumas.

longenne Nerkmuns. bill ellinine.

beirre Sivez.

folmuer lites:

Peurre livelulivu.

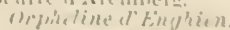

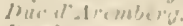

l) st hutm ps.

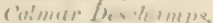

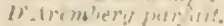

leirjherine

liserroredes crophedion
Deurre Sir ane.

livilre . A $b$ :an! .

Alinomil'ert):

Suiretlo.

birime inters.

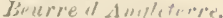

Lomence de liditivuts.

Slontersothy

Beurre Fonteriure.

lieurre livaulicu.

beurre lienuert.

beurre six.

lieurre I)rapiez.

lieurre sonlanec.

beurre st. Mesuter on t. Vero Frerlerick of llir. teintierg.

Beure d. (quenast.

l3eurre solecinlweiler.

leeurre Citron.

lieverre ol Elber:-

leurre ])uhanume.

beurre sle lirizutis. Ihex lonnex.

l'oire rles lones.

Benrre Liesn le Clerc.

bellrre Lirum.

Bunive liris.

(i) wey Deurre.

Bewredtimloike.

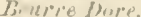

lientre Isumlert.

Renrere lienurge.

lienl liturve.

Li nrive

Giulen bie irre.

Bi ure or () ,

li) ume ar.Imblenac.

lis ure live

Therres tlu láeri.

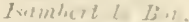

incor. Be a \% if 1, ,

Benrre di dumalive

fonre di.luelli is.

lienrere al andis.

Wilheinmint.

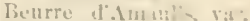

Leverre (olum ar.

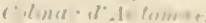

Benrti llillet of li er:

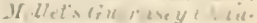
$m i n+l$.

beturre liasure.

lie urre ale liton:

lis urred de Flandre

lir ymonte.

lime thrition t, l'

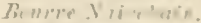

Hivlenl nl is line temins.

Dourer livis:

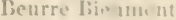

bis y mestit.

lienrre do Verti. . ine. Buture le elv. 
Jenre lint-[nmel.

Jieurre de finmmery.

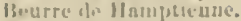

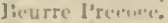

licurre Ino de. I'ute.

Jienre de Ibrallumula

linzi livet.

lichrese sit utin,

Jicurre kiturlek.

licurre h nox.

Jieurre diritonueau.

Jicurre lirumz:.

lieurre lirollsham.

leurre liruncau.

sirint Herbluin.

C'rumartune lirnuears

leurre bistnieq.

lie1 rre copiasument. (it jiermont.

Aurove.

Lenrre d"Ingleterre. Arobialue Charles. Ber d"tie.

Tielarre d'A volne.

J3eurre de Jisullwiler

licurre de liouins.

licurre do lannay.

licurre de Mulse.

lieurre de: I'alispol.

Jicurre de licinc.

licurre Charrun.

lienre cloatenay.

lieurre ('lairacats.

liturre colomis. cipue ine "l ilutuntn.

Be-urre Curtet. immle lifmi.

lieurre $y$ ielelet.

lie uree al. llbet.

benrre des licenines.

Beurre divole.

Jinure l)efuis.

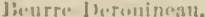

Be-urre al lowhien.

Jieurre d'llarilenpent.

licurre. llusal.

Jieurre liens.

Jeurre litilarel.

licurre diumlianle.

lieurte lipls dilliver, the (a)l.

lieurre do \%uriek.

Bu+urre Milan d"lliver.

Beurre firla d'lltier I.INe).

lieurr. Ilanecker.

lientrro II:arily.

Jienre lisurien

Jin urre linlahi.

Jinurre liegsuth.

lisurre langen|ler.

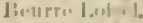

lievere Millet.

J3. Urre. Muire.

Janurre Nondalle.

licurro Nulsette. lic urre Ousllnot.

liviture l'aven.

lie urre I'hilliple l helfosse.

lieurre diosnatin.

lievrre salnt lentis.

Jirurre salut Ni.lulas. Juchesae dirleurs.

lavarre suringe. Duven at: Junilant.

livirre sugic rilu.

linurre Witeren.

lix:sl l.Ibutition.

liesi du linissey or (Yucsoy. louratie dis inu.

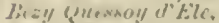

lieni de Chansery. Fichuasery.

Br.si de ( lismmontei Jhe, Variegated.

Bezi il Ileil. liezi lioyul, liumellimie.

lbisl Bosman.

Bezl de Mlontigny Jowis Dime.

Iijyentie Jusino.

Trunce de Montigny. Beurra liemain.

Bezi de La Mutte. lienrre lilanc de Jersey. Bein Armundi.

Bezy liarnler. liarnier.

besl de Vindre

Bezl les Veturans. liumeau.

Rezl Fipiren.

bezl Goubalt.

Beyl Ineouparalile. liezi sumbuartel. Berganoflo Sumsuariel

bezi kaint Vaast. bie urre beuument.

Bezl, Tnaly.

IBunne al lize

Rimne des Jlinies.

Bronne rle Zeex.

Ionnue de langueral. Belle at lionne d' Eere.

Bon Chretirn Funelaute

Bun Qustave.

bunno (liarlotte. Ren Chretien Fleminh. ron Clurtien ile Ture. Jun Cbretlen al l:spazzic. Bon ('hrelien yetuish.

Bon C'hretirn d'Ete.

Grucioli.

liecel's seedling.

Bon Cbratlen al litver. Bon (hretlen di.in. guisere.

Bon Chretle.n al A nzwlose varlecaleil.

Bisboy's Thumb.

Bluck Wurcester.
Blesk Pear if Horces ter.

I'urkingems \& Hitrden.

Buls Napoleon.

lion l'ure'st.

Ijonne limfles.

I3lawquet Aloxis

Blanyurt a Long Queue.

Jisnquet de suintonge.

Blanquet le Gror. livi louis.

Blanquet le I'elth blaninel al la perie. Blanche Fleur. cirs.

Blabuuct Precoce.

Boncuula.

Benrre Boucyuia.

Butirgemester.

Buturier Bourgemesler.

Brollabam.

Branders.

Sitini Gematin Bran. des.

Brialeinune

Brouml l’ark

sobden C'ourt.

Callet de Yaux.

Callot liusnt.

Caleuasse Jiosc

Calehneso de linaray.

Calebasse 1).lvigne.

Cialebusse llite.

Calelinsse Mink.

Calebasas Tuugnrd.

Caleliasso Verte. culebuase lircen.

Caletrase.

Culebarae Doulble Firdrol inlebuane d Vrollulielo. Beurre de I'ryener.

Cacn de France.

Camerign.

Cassante de Mars.

Catioka

C'harles Visn lloughten.

Charles simb.

l Charles Frealerlek.

Charloth de lirower.

folmar "1'Aluat.

('ount Lelle ur.

Conmple of I'arís.

4 imptu of Jisnders. asedller vle la ('inir Murechal da la limor

Culrbase Graseo. inlelupare glumalro Cirrifoure

l'vire dirafour.

Rould lle.

Triompluc da Frumbl Triumpler de lluslat

('vmpit+ de Lamy. Binrre Curti. bingler. 
Hrtrie Louixe Norr.

Murie lowise the Sec. (i)

Conseiller Ranwez. Conseiller de lianweze.

Goter.

Crassane d'Uiver.

Caperon du Mons.

Capucin Van Iluns.

Cent Comrounes.

Chair a 1)ame.

Cherroise.

Choice of an Amateur.

Colmar.

Jaunne.

De Juuize.

Incomparable. Winter lizogrieu.

Colmar Artoisenct.

Colmar d A rember. C'urtofell.

Culinar d'Automne Nonveau.

Colmar le silly.

Colmar des Invalldes. rin 1 oms.

Colmar d Eite.

Colmar Musque.

Colmar Douverain.

Coltin.

Citron des Carmes a Long Quene.

Countesse d'Alost.

Countesse de Lunay.

Cop ileat.

Cornelis.

Crassane Althorpe.

Catillac.

Bon Chretien d'-Iniens. churtrense.

Gros fillot.

Hunsire.

Teton de Fenus.

Chrumolsine.

Conan saint Marc.

Belle de Thouctis.

Cntberine Lambree.

Cure d' (Elenghem.

Chunmontel.

Brzi. le rhaumontel.

Winter Beurre.

Beurred IViver.

Orford (Yhanmonlel.

Charles of Austria.

Clara. clicire.

Clinton.

Colmar Ntell.

Colmuar Eplno.

Compretlo.

Communlure.

Crassit the.

Bir gumntles ('rolsaune.

Benre Plat.

C'revezue.

crawloril.
Croft Castle.

D'Aloutte.

Dame Verte.

De bavay. Poire de Buruy.

De Conq.

De DeuxOrs l'dn.

De Lainrortine.

1) Lestumire.

Delices ('barles.

Delices de Judoigne.

Delices de Louvenjoul. De Lowanyren.

Delices ds lit Meuze.

Delices diliardenumt. of Angers.

Deliees d'llardenpont, of belgiuus.

Fondunte P'uriselle.

Delices Dumortier.

Des Chasseurs.

Des deux sinurs.

Des Templirs Lianc.

Dingler.

Ducteur Bonvier.

Dencteur Caperon.

Docteur Troussean.

De Lourain.

Poire de Louruin

Bezyde Louxizin.

De Sorlus.

Bergumotle de Snilus.

Desiree Corruclis.

Cornelis.

Do Tungres.

Dundas.

Ellzot Dunflas.

Rousselel Jumin.

Diller.

Doyenne Rulin. Beurre lolin.

Doven Ibillun. Deucon liillun.

Doyenne Gunbult.

Dingennu Defisis.

Doyenne Downing.

Doctur Lentier.

Duchessu l'orleans Benrre Sizint Nicho$\operatorname{liz} \mathrm{s}$.

Stint Nieholes.

Duchesse do lierry al' Eto.

Ducliesse de Brabant.

Durhess al'a numuleme. Den Eprarunnais. Pesents.

Ducbesac d'ingouleme, variegated.

Ducheas d'A rembera.

Ibimortler.

1) mpuy Charles.

lioyenne liose:

binelienese do Mars

I)

Uumillard.
Dne de Nemnur. Beurre Vixez.

Louid Braxc:

Domun: Jutrurtier

busernay

Dovenne Bosarnack.

Doyenne bisanute tuurelle.

Donthle Philifie.

Beurre ile Serride.

tourelle Linussuck.

Doyenne d'Alenent.

Doye"ne d'llicer $U$ 'ile reon.

Doyenne Gris dllice, Vinureus.

Iongenne Murlire.

Duyenne dLicer Bunreitu.

St. Jrichul diricer

Doyenne a'Ele.

singniner linjenne.

Duchempde Berry it Ets of Bivort.

J)irenne sieulle.

sieulle.

Beurre Sieulle.

Lergumalle sieulle.

Duyent.e Gray.

Gray Butter Pear.

Gruy Deuns.

(irill Dolionne.

Iied Donenne.

st. Hickel Jire.

Innienne Ginlenx.

Irivenne lains.

Inimene inert.

Jinge" e "Autumu.

lievl bis nive.

Beriere lomelle

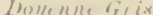

Dorenne. Wlite.

liverulien.

sit. Miclutel.

Inoynte blune

Jieit nute

Fellour bistler.

Bergulos.

Whi' biene.

Hirreick Bergarisol.

Ileanes.

Bimne Einde.

Sicige llanile.

silint Wiethel blane.

Nintore 1 'etll.

lieigner.

Bellore lilune.

Poired simon.

Poire II n-vieur

Citron de Nplemlier

finisser' im e

hiviver at $1=t u=n$.

liot li,ene

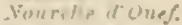

1) .h intatirne.

liziensiat. 
Jimile dill rest.

J.Jiza dillyest.

Jime rald.

Eilousal sogeret.

Jusunt l'ruilugne.

Jivine di:te. Findente Muspue.

sillin liert.

Jiperine.

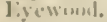

J: Tizaluth Mannlng"s.

lastner Ciastle.

lichasery.

Eilluxin, rie?

bizi ir Eilluskery.

lizi "t" hetanery. - Jiludulirne.

Jipiseniral.

Firlinter,

la Firtinge de Paris.

lat Fintume th lur mentier.

liersirmulte fortunee.

Eiserald.

Flemish Betuly.

finndante res Duis.

litllo dex Brix.

lincle de Flundres.

birgumatlo de Flun. dres.

Seurie des Fois.

lie urre sifence-errone(1):4y.

Jur? or J'uire Dary.

Fivilule.

Tinuguret.

Nounllo Gugno Henze.

Imperatrice do France. Busch l'eur.

Busch, or Boseh Noucille.

Desc sire

Jondente Abliret.

Fundante de lirist.

ransurte to lirest.

In'unmue the ('hesnealu.

Fondante de lapnillo.

Fondante do Mulines.

Fundarite de Noul.

lielle tle Nricl.

listle A pres Woel.

Findarito do Milisat.

Fundanto du Curuleo Angery.

Fondente Vin Mons.

Fondante Agrcentile.

Fondante de's l'res.

Furelle.

Aux Traites.

lirtin ila c erruil.

Furtunee.

Furale de Jerganotte C'ramennes.

Fuureruy d"Illver.
Francols.

Frulurlek lo Clere.

Jirealeriek the Wrtemberg. Isurre tle Mumlgero:aerroliandisty.

F'lorimuml l'uren.

Flenr do Xiclea.

snaw d4)wer.

Finur do Nuples.

C'unterse ile fircunt.

lie lisune l'elore.

lieure bionzec.

Fig reutrof Inija is.

Ei:ruso al'Alencun. Jerte Jungur do la Moyenne.

Figue illicer.

finbrourelis seedlug.

Geant.

ficneral de Lamuriclere.

fieneral dyutlilewe

liolden Beurre of is 11 ?

ijuire de Cambirubl.

Graclull de deracy.

Jersey Gracioli.

Grumal P'rincess.

Gros Lativean.

Gansils seetiel.

(itansel'd Late Jergazu)t I.

Gil o (iil.

(ritile el Elosise. buguliert.

Glace d'lliver.

Graml sulumun. Louis l'halifpe:

Gros Lucas.

(1) Cisruler.

Glrarillu.

Gloward.

liot.

Graslin.

lirunil sullel.

Cirls le Chln.

Gros Cotelisia.

Gustave de Bungagne.

General liverfuet.

lieneral C'anrobert.

(inneral du loniratel.

dideon l'arifunt.

Grailln.

(irosse Murle.

Glos lioussclet n'dout.

Genilesheju.

Green Citron of Bolemia. citronbirne.

Green l'eser of Yulr.

ireen Yair.

(i)out Murcesn.

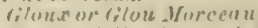
Beurere d' Jiaritenpont.

flardenjout illicer. Cintment al llirer.

filnden at A utemne.

lieure of arembery in frunce.
Goulu Morceru.

Jowi de Wurtemereru.

Leurro do ('imboron.

Got Luck de itmliron.

hronjurinz Ferdinune

II ent? coth

Ilentheot de Gore.

Gores 11 erillecut.

Il allun.

Besi Fondant.

Jante Nontece.

Jeliote Junudis.

líouxatel flemelin.

Ilenri Bivirt.

Ileurl ingeron.

IJ enrl 11 .

Hentilualle.

elecuuin.

Futur $i$ Iforgue.

lis urre inunas.

l'oire I nullats.

llerleart do Theurg.

Uesarel.

Hitacl.

Jlovey.

lleuticl.

llenrletta.

Ilenri Bivurt.

IIerleart.

llerlcart do Thusy.

liushmore's bion chlle. tien.

Ilncon's Incumpernisle.

Ir compurable llacentu.

Targunclle Finflish.

lieul Jitrumelle.

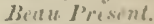

Sicet Summer.

beurre de l'uris.

C'uillalle.

('uisse Mudume.

Grox cuisal birderme.

I:pererine.

sivint sitmxon.

l'oir de tid'stes tes J'inces.

Srint tamlicrt.

selle lerste.

aivgonilla, frenels.

liellixsime al" $\mathrm{Fl}$.

lillisnime sirjle me.

lidlisaime Jublunalle.

fied Musiculel.

Siunmer lieraty

lied etheed:

sumeme.

rhum umintel ar Ele.

Fermilion at kis.

subine it bile.

lingliah lied cheed.

libul.

Jalotaslo de fincenas $V$ ve Jen.

Jean de Vitec. 
Julienne.

Josephine Ile Ma:ines.

Jules Bivort.

Jatousic Tardive.

Jacquemine.

Jininette.

Austrasie.

Jeurre d'A ustrassie.

Beurre Saint llelier.

Bergamotte cheminette.

Pirolle Jisioi.

Suline.

Wilkelmine.

Josephine.

Colmur Jumineile.

Jansenus.

Jolivet.

John Moutich.

Jules Birort.

Jutte.

Jurardiel.

Jalvie.

Inconnu Tan Mons.

Imperiale, Oak-Leaved.

King Elwards.

Knight's Monareh.

Knight's Seedling.

Finight's Edwards.

La Caslcbirne.

La I Ierard.

La Juive.

Laure de Girmes.

leopold tho First.

Leurs.

Long Verto of Coxe. Mouille Bouche, crion. Long Green.

Long Green.

Leon le Clerc.

Leonle clere Lexul. Blune-Per-tie

Little Mruseat.

Little Musk:

Y'etit Mrusk.

Primitive.

Muscut I'etit.

Sept-en-Gueule.

Lutiso Jionne. Louiso Bonne Real.

St. Germain Iilence.

Louise de Careelles.

Lotiso do Prusse.

Lunise lionne de Jersey. Loulise Bonne d"Arian. ches.

fonne de Lonsineral. Beurre, or birnne Louise d.Aenndore.

Hillium the Fourth.

Incien Leclerc.

Iouis Dupont.

Limon.

Bentre litgersten. bergamotle Leruisis
Lientenant Poitevin.

Liberale.

La Canas. bon-P'trent.

Leon Leclere.

Lean Leclerc Epineux.

Mansuctte.

Marie Louise.

Princess Parme.

Marie Chretienne.

Forme Mrarie Louise.

Braddick's Field Stanclurvl.

Marechal Dillon.

Marechai lelissier.

Marianne de Nancy.

Mignonne d'iliver.

Millot de Nancy.

Marie Louise-the newo.

Martin Sec.

Rousselel d'Iixer.

Madame Durien.

Madame Elisa.

Madelejne d'Angers.

Marechal de Cour Conseilleur de la Cour. Duc d'orleans.

Marquise.

Meduillo d'Or.

Melon.

Menagerio.

Messir, dern.

Jr. John.

Messir Jean Gris.

Messir Jean Golden. Jolin.

Monsieur Jolun.

It sasir Jean Blanc.

Miel des Carmes.

Monsulgneur Afiro.

Monstrous IFuod. Nuin Vert.

Musert T'Allemand.

Muscat Rubert.

Musqueo d'Esperne.

Micbaux.

Comple de Michaux.

Madeline.

Mugulalen.

Citron des Curmes.

Green Chisel, incor.

Lirrly chuumontel, incorrectly.

Malellne, variegaled.

March Bergamut.

Ituecas.

Muscat Robert. Ivireula lieine.

I) Ambre.

st. Jeun Musizuee Gros. Ilusk liobine.

Fivrly Qucen.

Queen's l'ear

Mario I'urent.
Napolpon.

Beurre Napoleon.

Bon Chretien Norjoleom

Capticeol st. Lelena.

Charles 1 .

Charles d'A ustria,jneur

Gloire de 1 Empereur.

Liard, incor.

Meabille.

Mredaille.

Hurtemlerg, incor.

Sucree Duree.

lioi de Rome.

Eonaparté

Nectarine.

Nielle.

Beurre Niel.

Puire Noil.

Colmar Bosc.

Fondanie du Bois, in correctly.

Jeufinalsons.

Belle Alliunce.

Neure Jaison.

Serrutier d A utomne.

Noureau Poltcau.

Retour de Rome.

Tumbe de l'Amateur.

Nonveau simon buuvier.

Ne PIus Meuris.

Niles.

Omer Pasha

Orpheline Colnar.

Orange d'Hiver.

Winter Orange.

Passe Colmar.

Pusige Colmar Enineux.

Pesse culmar (iris, ur Dore.

Passe C'ulmar tonreau.

Pucelle Condexienne.

Golmar Gris.

Anunas d'tirer.

Beurre Colmur Gris.

I'recel.

Fondinte de Pinniser.

Fondinte de Mens.

Be urre d ilruenaon.

liegintin.

inimar Mtardenpont.

Cinar voureraine

Colmar I'reule.

Culmur Dorce.

Gitulier.

C'elliste.

Marotle Luere Ianne.

I'use'vt de' Julines.

D"Anamies.

Passe Colmar of Bolsium

l'asse Colmar of France.

I'asse Colmar Musque.

l'ater Doster.

l'aquener.

leach Pear. 
Polre Peche.

l'ungetbly.

l'asonas ilu I'ortuga!.

sinmoner l'urtugul. Miller's Fiarly.

l'aralise d'A untumae. Cilebirane Bianr. Midriat Sourelle. Jincers lloriunne.

Phlillype live's.

l'lo 1.5 .

lolred: Ilbret.

Iiviro il a burilanee.

l'ulte dos C'basseurs.

lidire de Intplac. To lepino. Jekejine.

Paul Ambro.

I'revont. I'oire Precost.

Prince Altert.

J'alllesn.

Jiut' Hrollec.

Jitt's Surpuseo Mirio. Surpusae Mario Loulae. incurrect.

Princess Marlia.

l'rincess Charlutte.

l'rincess of Orange. l'rincess Conquello.

Paln et Vin.

CVurumoniel Anglaiso. Chens lipt. Chene lin.

Parfum d'A mut.

Parfum dillier.

J'aul Thlens.

Jomme.

l'roilli.

I'rufessor Dutreull.

l'restilent l'arigut.

I'rince Imperial.

l'rlncess llelene d'Orleans.

Queen of the Lorr Connirles.

Queen of Witherlunils. fieine dea l'ays lias.

Qullette.

Treino des Relges.

lieine dea l'oires.

lielne dillver.

liovillere.

I:Il-bmore.

Iionilelet.

Jisalezer.

Henger des Vlerges.

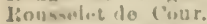

linurseler de kuchefurt.

lionselet dillsur.

linnsarlet le firos. liot atite.

l:oumselet varlegated.

Ionsaleq l'erulreau.

livusselet do Moester.
Ferdinanat de Meesier.

Surpisine Meurie.

I: unsatiine.

I: susaction.

liosale dike.

liubine.

liugal dilliver.

1:unss, let Ilatif.

Eidrly Cotherino.

histlern.

Piljerua Jear.

Eilrly Rutesxelet.

l'erdieirn.

I'olre de rliplpri.

lionsselet de libelus.

IBunearlet.

I'etut Irousaralet.

sivice I'err.

Jusk Tewr.

Retour de linme.

Lousselet ith-peren.

liousselet lloulse.

Ronsselet Finfint l'rodigue Enfint I'rotigue.

Rosabirne.

litidelles.

Beurro indusson.

I'oire livitelle.

Rousselet lanilervecken.

I:ousbelet stuttgart.

Iistenu Gris.

Deurredo Louraln.

Sablne d'Hlver.

saint Andre.

Salnt Augustin.

Sulnt Groorges.

salnt fiermaln.

si. Germain Gris.

Inconnut Lajisre.

Sit. German surme.

Salnt Gerumain Van Vons.

Salnt frermaln, varlogated.

salne (iermaln Gris.

salne cihislein.

Quinnifrillc.

Huek . Woutreh.

Salnt (iernuln Brande's.

sialnt Andro.

salnt Menin.

sinint Isaure.

sulnt dean liapliste.

sinine Joseph.

salnt I, muls.

salnt Jlichel Archango. flomligilatel.

Salne Vincent do l'aul.

sasint luretbees. koyule.

Nuurelle.

Snint Denla.

sangainulu.

sirnguine de France.

Rangnine d'lullc.

Sana l'ean.

Skinloss.
Pairo Sanspeau.

Fleur de liuignes.

Serrurler.

Aiurrier al al utunine

Fondunte do Jillot.

Siman Besurfer.

Silegnata

Simion.

Sirmvenir de Simon Bouvlet

surlus

sucree to 7nrich.

sucree Vert.

sujireme d'I iray.

supremo luinifur.

suzette de liaray.

suldat Labureur.

Auguate Iun hivtll.

souvernine de l'rlntempe F'viro do l'rintemfin.

Snuveraine d'lite.

ityrian.

Supreme de Qulnejer.

- in puase Menric

Silrpasse Cirassane.

saluc l'ere.

De I'ape.

Suequet.

sultan.

sueree de Corinne.

Sucrea de Iloyerswerder.

Summer ?t fiurmain.

sluorts st. fiermain.

¿V. Germuin it Fy.

Si. Germatin of Mortin.

Summer Frane l:asl.

F'ranc leal d' Ele.

Forselunte.

Gros Miret d'Elc.

Green Chinel.

Green sugar.

Super lonilane.

Swan's ligur.

Muor-fuinl Fizo, Ineorrict

Summer lose.

Eiplne lioxe.

Cilllot linant d'Ete.

Thorny liose.

(lonen.

Eipine d Fite.

I'vire de lirse.

Eupine it tilo coleur liose.

Snmmer lion Chritien.

In Chrelien at Fite.

Gratioli.

Brutioli al Ete.

fromlioliali linment.

summertroed r hriation

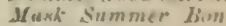
ihretien.

Soinmer Apothikerbirno.

Sommer fiuto christen. birne.

Dio Sommer Christon. birne. 
Large Sugar.

Sylvange.

Bergumotle Sylvunge. Green Syleunge.

Tilllngton.

Turquin de Pyrences.

Theudore Van Muns.

Thumponn's.

Thueslinek.

Triomphe de Jodoignt.

Taluont.

'I'unnelet.

Triomphe do IIasselt.

Triomphe de Somvain.

Trlomphe de la Pomologie.

Tavernit'r do Boutogne.

Tresor d'Anzour.

Tonnosu.

Uveedales St. Germain.

Angora.

lound Pear.

Beculy of Turrensen.

Relle Angevine.

Belle de Jersey.

Bolixer.

Ducherie de Rerry.

Duchesse de Eerry l'lliver.

Grosse de Brusplles. Royul. d'Angleterre.

Urbaniste.

Bewrre Picyuery.
Count Coloma.

SI. Jeare.

Deurre Irapies.

Lonise d'Urleuns.

Urbaniste Seedling.

Van Mons. Leon le Clere.

Valette.

Vun Assehe.

Vuliqualin.

Sit. Germain Faupuelin. Verte Lungue d'Arigers.

Verte Longue Sulyne.

Ferte Longue Panuclie. Culotlede Suisse.

Vezouziere.

Víeompte de Splelberg.

Vigneuse d'Esjeren.

Vingt Mars.

Fallie Francho.

De Vullee.

De Renizheim.

Bonne de lienizhein.

Virgalouse.

J'oire Glace.

Chumbretle.

Bujuleuf.

Viear of Winkfeld.

Cure.

Irom. le Cure

Clim.

Comice du Toulon.

Belle idrienne.

Belle de Berry.

Lelle Ilelorex.
Walker.

185 of $\operatorname{Tan}$ Hons.

Wende I.

Wille moz

Wredon.

WIIIlam Prince.

Wiudsur.

Summer Bell.

hionge.

Sinisse, Jurlame.

Winter Nelis.

Bonne de Iralines.

colmar Velis.

Nelisd'lliver.

Beurre de Julines.

La Bonne Mulinoise.

Milanaise Cuvelier.

Etourneau.

Waterion.

Duc de Biabrant.

Desiree J'an Mons.

Findante charneure.

Fundante des Chur neusa.

Beurre Charneuse.

Milde titerloo.

Jumin.

Belle Excellente.

Iat.

Iutte.

\%ephyrin Gregoire.

Zejhgrin Louls Gregoire. 



\section{N D E X.}

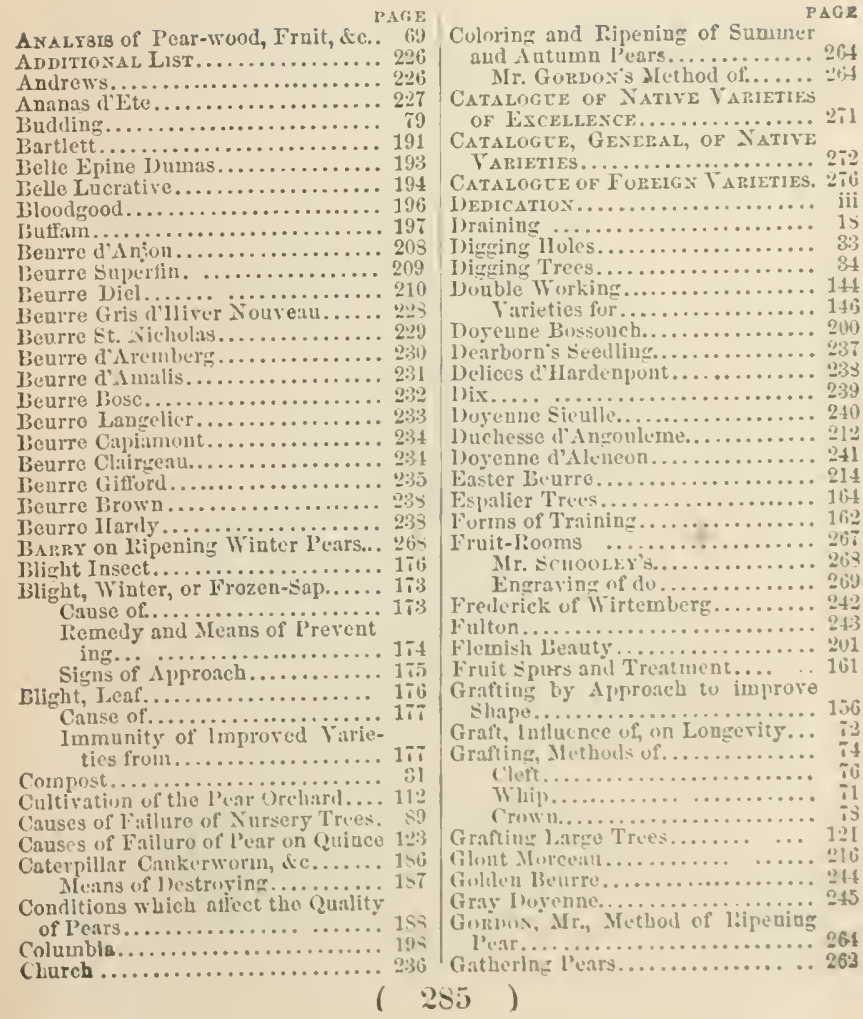




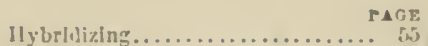

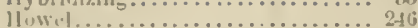

Jledinz in.................. 1113

Intruluetion................... 1:3

Itvigurating U!l Trees. .. ... 1:

Insect liliglit.... ............. 1it

Iniproved Varieties, immunity from leaf-blight.................. 17

Leaf-bliglit of Seediings............ 523

Law reace.................... 20.2

Loulse Jonne de Jersey........... 21s

Manure for l'ear Trees............ 27

Manuring.................... 26

Manures for Xurserv stocks....... Gi

Epecisl do. for l'ear Trues..... 117

Malcling.................... 11

Cropplng fer do............ 116

Monar, A. (1., Arlicle on seale Insect........................ 17?

Monre A. U., Article on l'enr sing.. 1-2

Madeleine..................... 2t7

Maric Louise................... 24)

Mapketixg I'ears .............. 263

Napuleon....................... 249

Nouveau Poiteau.............. 251

Onobilaga .................... 251

Oswego Benrre................ 25z

Old Trees, Inrigorating........... 120

I’Alit 1..................... 17

Part II .................... 45

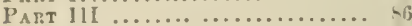

PART IV ................... I:2

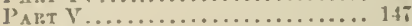

I'A I:T VI.................... 1 is

PART VIl....................... Its

I'art Vill..................... 1n

P'A I.

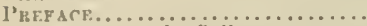

I'reparation if the Soil............

l'lowing and Cropling the fircund.

l'ropagation ly Layers and Cuttings

Janting secd...................

I'lanting stuck $3 \ldots \ldots \ldots \ldots \ldots \ldots$.

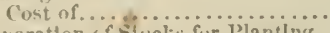

preparation of Slucks fur j'lanting..

Planing T'ren.................. 10t I'roper .1 ge for.............. 90

Depth of ................. 110

J'an of Arranging Pear Orebaril.. 106

I'runin: and Ioot-pruning befure l'lanting.

l'yramillal Shape, Ailvantage of.... 147

Pruning to form l'yramids......... 1:0

Jrunine to a Jiu.1................ 1:

J'runing, liules for.............. I60

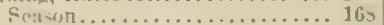

I'runlng lioots, liffect of, on Shape,

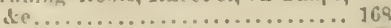

IIr. livivers on lo............. Ifis

J'arsoname..........................

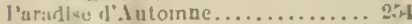

j'asse rolinar......................

l'ear Slin...................... 1-2

Qnlnce siturka............... 6i)

I'roprogatlon of ........... 61
PAnN

Quince stocks, onlee of........... 12: (Quince, Canses of lallure of Pear on 12:3 Uuinee-stuck, Advantuges of ....... I2t lireck.s.s.' L. E., Irticlu on... 1:t WiLut:. M. I'., do. ..... 1:*) Wo. rlo. .... 132

lierst. li. de. .... 1:6

Ilutri, C: do .... 135

liules fur growing Pear on..... 138

Itootin's of the l'ear above..... 139

Ilow to prudnee it............ 1.13

Quenouille Iraining............... 164

(qualities now required for Market

rears..................... 1 s9

Removing tho Wuod of Uld Dwaris. 153

lioot-pruning, Sic., Effect on Shape

and J ruitin $\ldots \ldots \ldots \ldots \ldots \ldots \ldots . . \ldots 3$

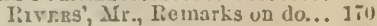

Rostiezer.................. 8.

lipening Winter Pears ............

Uitienlty of............... 266

I.aws governing, do.......... 265

Rooting of the I'enr.............. . .

lieplanting the l'ear to form Fibrous

lionts..................... 102

Scolytus pyri................... 178

Seale Insect.................. 173

Wishes to destro $\ldots . . . \ldots \ldots . . .179$

A. O. Moon:1's Arificle on.... 179

Sln, Pear.................... 152

A. O. Jooves Article on...... 153

Season for liemoving and Planting

Trees...................... 91

Shelilon.......................

Soluat Labonrenr.................. 25i

st. Michael Arelannge........... 25.5

sickel...................... 204

Soils atfecting the Quality of l'ears. 261

sunmer Pinching............... 159

Suason for l'runin............. 163

Suils fur the I'vir............... is

Scedlines................... 4h

Leaf-lilight of .............. si

New Varietion of ............. n

Cultivation of .............. sij

Vax Iloxs' Theory of Improvement................... 52

Indicutions of goud iarictics....

Secd-planting............... 43

Thinning Fruit....................

Terms relating to Quality........ In

Trenching.................... 21

('ost of .................... $2: 3$

Transporting.............. $4: 3$

Iroaniste................... 293

VAN Mosis Theory of Improving Sredlinga................. $\quad$.

Viear of Winkileli................ 220

Withered Trees. Treatuent of...... 103

Winter l'ears, lifpeniug of........ gess

1)iflenlty of .............. $260^{\circ}$

Lnws fuvernlng do............ 265

Winter Nulls.................. 2n?

Vilto Doyenno.................... 24 



DATE DUE

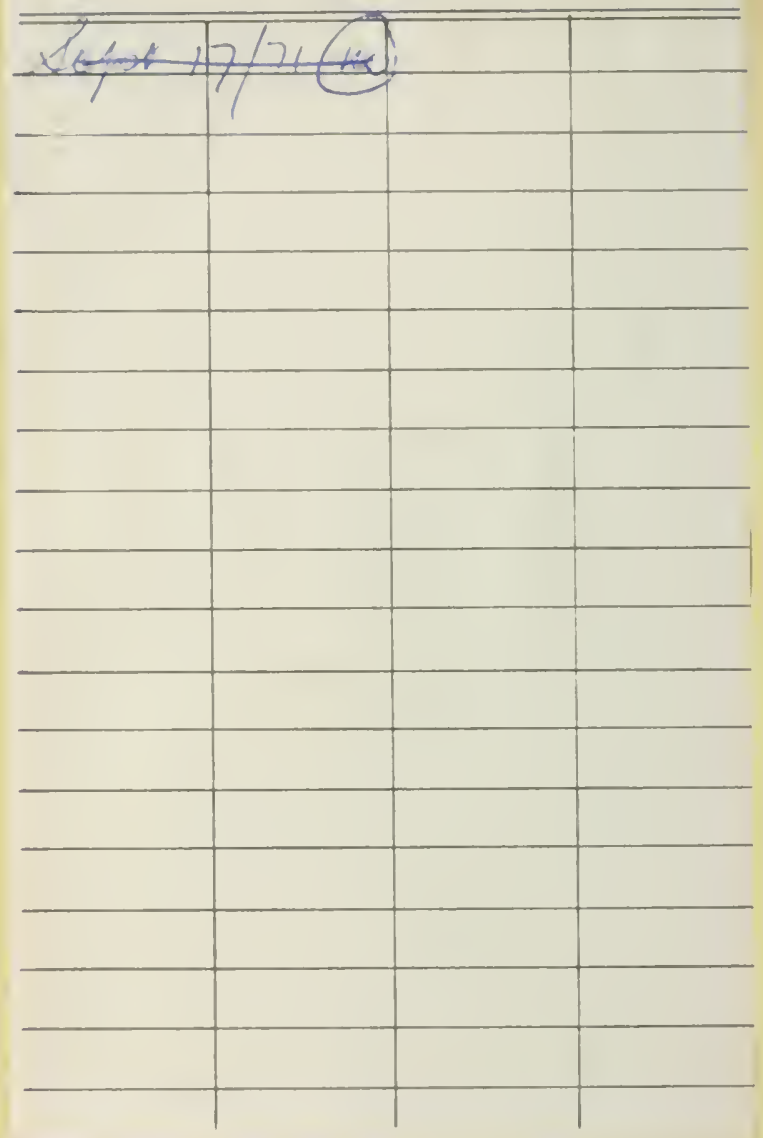




\section{7}

$$
\begin{gathered}
\text { SB } 373 \\
\text { F } 45
\end{gathered}
$$

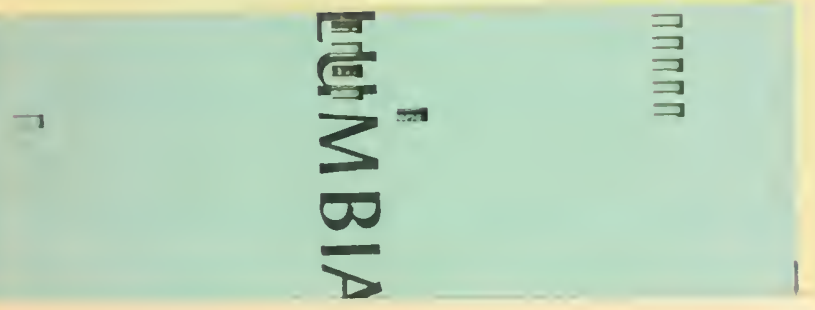

FuREQTRY

AGRIDULTLRE 
